\title{
Døden i livet
}

Aud Johannessen, Norunn Askeland, Iben Brinch Jørgensen og Jorun Ulvestad (red.) 
Døden i livet 

Aud Johannessen, Norunn Askeland, Iben Brinch Jørgensen og Jorun Ulvestad (red.)

\section{Døden i livet}


() 2018 Aud Johannessen, Norunn Askeland, Hilde Bondevik, Iben Brinch Jørgensen, Ellen Kristvik, Eva Maagerø, Olav Solberg, Oddgeir Synnes, Lisbeth Thoresen, Jorun Ulvestad, Geir Winje, Bente Aamotsbakken, Arnfinn Åslund

Dette verket omfattes av bestemmelsene i Lov om opphavsretten til åndsverk m.v. av 1961. Verket utgis Open Access under betingelsene i Creative Commons-lisensen CC BY-NC 4.0. Denne lisensen lar andre dele og bearbeide verket for ikke-kommersielle formål, under forutsetning av at det oppgis korrekt kreditering, lenke til lisens og indikasjon på om endringer er blitt gjort. Du kan gjøre dette på enhver rimelig måte, men uten at det kan forstås slik at lisensgiver bifaller deg eller din bruk av materialet. Lisensvilkår: https://creativecommons.org/licenses/by-nc/4.0/legalcode.no

Denne boka er utgitt med støtte fra de institusjonene der forfatterne har sin tilhørighet: Universitetet i Sørøst-Norge, Universitetet i Oslo, Akershus universitetssykehus og VID vitenskapelige høgskole.

ISBN PDF: 978-82-02-58934-9

ISBN EPUB: 978-82-02-60959-7

ISBN HTML: 978-82-02-60960-3

ISBN XML: 978-82-02-60961-0

DOI: https://doi.org/10.23865/noasp.40

Dette er en fagfellevurdert antologi.

Cover Design: Cappelen Damm AS

Cover Image: Pixabay, under en CC0 Creative Commons lisens.

Cappelen Damm Akademisk/NOASP

www.noasp.no

noasp@cappelendamm.no 


\section{Innhold}

Forord................................................................................................................. 9

Kapittel 1 Dylan og døden: menneskeleg liding og narrativ etikk .................15

Oddgeir Synnes

Kapittel 2 «Eg veit i himmerik ei borg » og «Eg ser». Metaforar i

salmar brukte i gravferder

35

Norunn Askeland

Kapittel 3 På tvers av døden. Grensa mellom levande og døde i

kulturhistorisk lys

Olav Solberg

Kapittel 4 Religiøse forståelser av døden

.69

Geir Winje

Kapittel 5 Steder for død. En vandring gjennom retorisk dødseulogi .87

Iben Brinch Jørgensen

Kapittel 6 Død i mors liv. Endringar i handtering og markering av dødfødslar i Noreg. 103

Ellen Kristvik

Kapittel 7 Claes Gill om den andres død og den egne. En lesning av «Portrett av en avdød venn» i lys av Heideggers dødsfilosofi Arnfinn Åslund

Kapittel 8 Jeg steg inn i en annen historie. Om Simone de

Beauvoirs bok En lett og rolig død

Lisbeth Thoresen og Hilde Bondevik

Kapittel 9 Metaforer om sykdom og død: en litteraturoversikt 153

Aud Johannessen og Norunn Askeland

Kapittel 10 Hvilken farge har døden? En analyse av Erling Forfang

og Annlaug Auestads bildebok: Noen sier døden er svart (2006). 171

Eva Maagerø 
Kapittel 11 Barnet som morder i Karin Fossums forfatterskap...................... 189

Bente Aamotsbakken

Kapittel 12 Barnedrapenes stereotype medielogikk. Avisers

førsteoppslag når barn dør etter vold og omsorgssvikt i familien . 207

Jorun Ulvestad

Om forfatterne

.229 
TIT GÅR JEG IKKE UD AF LEJLIGHEDEN EN HEL DAG JEG SER SOLEN STÅ OP JEG SER DEN GÅ NED JEG SIDDER I MØRKET JEG LÆSER IKKE JEG SKRIVER IKKE JEG HØRER IKKE MUSIK JEG TÆNKER MED FORAGT PÅ FOLK DER SKRIVER OM DØDEN SOM KOKETTERER MED DØDEN MALER DØDEN DØDEN GÅR VED SIDEN AF OS DEN ER VIRKELIG DEN ER IKKE SKØNSKRIFT IKKE FUCKING FORESTILLET LIDELSE DEN ER VIRKELIG DEN ER EN MUR DET GØR MIG RASENDE MIN SORG GØR MIG RASENDE HADEFULD JEG ER RASENDE OVER AT VÆRE ISOLERET I MIN SORG JEG HADER KUNST JEG HADER ALT DET JEG SELV HAR SKREVET OM DØDEN FØR TIT GÅR JEG IKKE UD AF LEJLIGHEDEN I FLERE DAGE JEG SIDDER I MØRKET JEG SIDDER I MØRKET LÆSER IKKE SKRIVER IKKE HØRER IKKE MUSIK $^{1}$ Fra boken Har døden taget noget fra dig så giv det tilbage Naja Marie Aidt (2017, s. 42)

1 Brukt med tillatelse. Utdraget er ikke omfattet av CC BY-NC 4.o-lisensen til boka, og kan ikke gjenbrukes uten tillatelse. 



\section{Forord}

Denne boken er en tverrfaglig vitenskapelig antologi om døden sett fra ulike perspektiv. Utgangspunktet vårt har vært å synliggjøre at døden er til stede i livet. Vi ønsker å imøtegå den utbredte oppfatningen om at døden er lite synlig i vår kultur, og at vi snakker lite om den. Antologien utfordrer forestillingen om at døden er tabubelagt, fremmedgjort og taus i vår tid.

Vi har valgt tittelen Døden i livet for å understreke at døden og tankene om den er med oss og følger oss gjennom livet. Døden åpenbarer sin tilstedeværelse på mangfoldig vis: Vi ser den og opplever den i våre fysiske omgivelser, vi hører om den eller leser om den i taler, dikt, musikalske tekster, salmer, nekrologer, biografier, bildebøker, romaner og avistekster, og vi uttaler oss om død i samtaler med hverandre og gjennom fagspråk om sykdom og død. Ikke minst viser vi vår forståelse av døden gjennom visuelle uttrykk som i avisbilder, i bokillustrasjoner og i de språklige bildene og metaforene vi bruker når vi omtaler den.

Antologien består av bidrag fra forskere fra ulike fagfelt som helsefag, pedagogikk, idéhistorie, religionsvitenskap, litteraturvitenskap, språkvitenskap og retorikk. Tanken bak en så bredt sammensatt antologi er nettopp å kaste lys over hvordan døden er synlig i livet fra vugge til grav, både i eldre og nyere tekster.

Døden i moderne sangtekster behandles i kapitlet «Dylan og døden: menneskeleg liding og narrativ etikk». Her tar Oddgeir Synnes for seg Bob Dylans behandling av døden i sine sanger. Gjennom en nærlesing av sangene «Ballad Of Hollis Brown» (1963) og «Blind Willie McTell» (1983) viser han hvordan Dylans tematisering av døden kan knyttes til ulike posisjoner innenfor feltet «narrativ etikk», et fagfelt som vektlegger hvordan litteratur og fortellinger innebærer etiske vurderinger og problemstillinger. Her viser Synnes hvordan døden for Dylan i to konkrete sanger danner utgangspunkt for to svært ulike etiske og estetiske framstillinger.

Norunn Askelands kapittel er en analyse av to ulike salmer brukt i begravelser, den tyske salmen «Eg veit i himmerik ei borg», oversatt av 
Bernt Støylen, og Bjørn Eidsvågs «Eg ser». Den ene er en middelaldersalme, den andre er fra 1983, og begge har en enkel metaforikk om livet og døden. Begge framstiller livet og døden som en strevsom vandring, men når det gjelder livet etter døden, skiller salmene lag. Middelaldersalmen tegner et klart bilde av et liv i velstand og fryd, mens den moderne salmen ikke berører temaet i det hele tatt. Begge er åpne tekster som gir rom for leserens meddiktning, selv om den ene har et spesifikt kristent innhold, og den andre har et mer allmennmenneskelig preg.

I neste kapittel drøftes døden i et kulturhistorisk lys. Under tittelen «På tvers av døden» tar Olav Solberg oss med til grenselandet mellom levende og døde helt tilbake til tekster fra norsk middelalder. Tradisjonskilder gjør det klart at grensen mellom liv og død ikke ble oppfattet som absolutt, men lot seg overskride til visse tider og av visse personer. Forholdet til de døde fungerte blant annet som et korrektiv for de levende og ga retningslinjer for hvordan et godt liv skulle være.

I kapitlet «Religiøse forståelser av døden» tar Geir Winje utgangspunkt i tradisjonell vestlig religion og viser hvordan forestillingen om døden har endret seg i tiden etter 1850. Den framvoksende naturvitenskapen og innflytelsen fra østlig religion medførte nye forståelser av døden i så ulike religionsformer som Jehovas vitner og mormonene, i verdensanskuelser som teosofi, og i nyreligiøse strømninger som spiritisme. Etter hvert førte migrasjon også med seg religionspluralisme. Den teoretiske oversikten nyanseres ved hjelp av tre fortellinger: Den første er om Jack O'Lantern (halloween eller allehelgensdag), den neste er om Mogallana, en av Buddhas disipler (vulan), og den siste er fortellingen om en nær-døden-opplevelse (senmoderne alternativ religion).

Et menneskes dødsscene og endelige hvilested fungerer som en del av grunnlaget for hvordan han eller hun karakteriseres og minnes. I kapitlet «Steder for død. En vandring gjennom retorisk dødseulogi» tar Iben Brinch Jørgensen leseren med gjennom ulike retoriske sjangrer og praksiser hvor stedet for død tillegges betydning. Turen starter ved Napoleons dødsleie på St. Helena og fortsetter blant annet forbi Plutarks sammenlignende biografier og talene ved de offentlige begravelsene av falne soldater i Athen. Vandringen ender ved de ulike stedene hvor vi minnes våre døde - steder for død som rammer inn livet. 
At døden er utfordrende å forholde seg til, og at tiden endrer hvordan vi forholder oss til den, beskrives gjennom Ellen Kristviks kapittel «Død i mors liv». Her beskriver forfatteren en gravlund med en stein uten tilhørende grav, satt opp til minne om de mange som er gravlagt i det skjulte, som anonyme blindpassasjerer i andres graver. Dette handler om de som døde før de ble født, inntil nylig et ikke-tema. I dag er oppretting av eget gravsted, bruk av eksisterende familiegrav eller nedsetting i minnelund et valg for de etterlatte foreldrene. Denne nye praksisen åpner for at omfanget av sorg ikke kan avgjøres av noen utenfra, heller ikke sorgen over dem som dør i mors liv.

Gjennom flere tusen år har diktekunsten vært et språk for avansert tematisering av døden. På dette området viser Arnfinn Åslund hvordan Claes Gills «Portrett av en avdød venn» fra 1939 kan kaste lys over noen problematiske punkt i Heideggers dødsfilosofi i kapitlet «Claes Gill om den andres død og den egne». Dette gjelder særlig forholdet mellom individualitet («min-het») og sosialitet («med-væren») med tanke på døden. Det er bare ved å anerkjenne dødens individualitet at man også kan være til hjelp for den andre i relasjon til døden.

Døden er et gjennomgangstema også i den franske forfatteren og filosofen Simone de Beauvoirs forfatterskap. Utgangspunktet for Hilde Bondevik og Lisbeth Thoresens bidrag er en nærlesning av hennes personlige bok om sin mors dødsleie, En lett og rolig død. Forfatterne er særlig opptatt av hvordan Beauvoir forstår og forholder seg til døden. I kapitlet «Jeg steg inn i en annen historie. Om Simone de Beauvoirs bok En lett og rolig $d ø d_{»,}$ drøfter de hvordan hennes erfaringer og konteksten for morens død kan være en inngang til å forstå noen av de eksistensielle og allmennmenneskelige sidene ved døden i dag, femti år senere og i en norsk kontekst.

Hvordan vi språklig omgir oss med døden, er belyst i kapitlet «Metaforer om sykdom og død: en litteraturoversikt». Dette er en gjennomgang av metaforforskningen om sykdom og død innen helsesektoren, skrevet av Aud Johannessen og Norunn Askeland. Studien er basert på forskning om døende pasienter, deres nærmeste familie og helsepersonells bruk av metaforer om sykdom og død. Her finner vi krigsmetaforer, reisemetaforer, familiemetaforer, naturmetaforer og metaforer om søvn og hvile. Vi 
finner også metaforer om håp selv $i$ håpløse situasjoner, og metaforer som beskriver døden som en åndelig reise.

Bildeboka Noen sier døden er svart av Erling Forfang og Annlaug Auestad kom ut i 2006. Hovedpersonen i boka, Alfred, reflekterer over døden ved å ta utgangspunkt ikke bare i fargen svart, som så mange forbinder med død, men også i lyse og glade farger. Det hjelper ham med å bearbeide alle tankene han har fått etter at lillebroren til venninna døde. I kapitlet «Hvilken farge har døden? En analyse av Forfang og Auestads bildebok Noen sier døden er svart», tar Eva Maagerø opp hvordan farger skaper mening og gis mening $\mathrm{i}$ kulturen basert på multimodal teori. Viktig er det også hvordan farger hjelper hovedpersonen til å få ulike perspektiver på døden, perspektiver som ikke bare er forbundet med det mørke og svarte.

Døden i kriminallitteraturen behandles fra en litteraturvitenskapelig synsvinkel av Bente Aamotsbakken i kapitlet «Barnet som morder i Karin Fossums forfatterskap». Det uvanlige ved Fossums kriminalromaner er at hun lar barn inngå i rollen som mordere eller drapsmenn. Dette er samfunnsromaner i like stor grad som kriminalromaner, da Fossum er mer opptatt av hva som utløser en forbrytelse, enn av detaljene omkring ugjerningen. Det er med andre ord mer tale om hvorfor enn hvem og hvordan. Barnet er sårbart idet det er utlevert til voksnes omsorg og grensesetting gjennom oppvekst og skolegang. Dersom slik omsorg uteblir, kan et barn utvikle kriminelle tendenser.

Til sist i antologien bidrar Jorun Ulvestad med kapitlet «Barnedrapenes stereotype medielogikk. Avisers førsteoppslag når barn dør etter vold og omsorgssvikt i familien». Gjennom analyser av avisers førsteoppslag får vi innblikk i hvordan barnedrapene hovedsakelig konstrueres gjennom en diskurs der politi og rettsapparat tildeles rollen som hovedkilde. Dette journalistiske valget bidrar til en stereotyp logikk som definerer virkeligheten i tråd med tradisjonelle politi- og rettsfaglige verdier, mens andre perspektiver, verdier og interesser blir oversett. Slik bidrar avisene til å forme publikums forståelse av barnedrapene som historier om foreldrenes kriminelle gjerninger. Det som går tapt, er perspektiver på mulig systemsvikt innenfor hjelpeapparatet, og ikke minst historiene om barns død i familien som sosiale hendelser - forstått gjennom fortellinger om tragedier, sorg, fellesskap og forsoning. 
Som kapitlene viser, kan døden ses i mange ulike perspektiv. Felles for mange av bidragsyterne er at døden ofte kaller på våre sterkeste følelser, slik Naja Marie Aidt skildrer i store bokstaver i sin prosatekst, gjengitt i innledningen til denne boken.

Aud Johannessen, Norunn Askeland, Iben Brinch Jørgensen og Jorun Ulvestad (redaktører) 



\title{
KAPITTEL 1
}

\section{Dylan og døden: menneskeleg liding og narrativ etikk}

\author{
Oddgeir Synnes
}

VID vitenskapelige høgskole, Oslo

\begin{abstract}
Summary: Death has been a central theme throughout Bob Dylan's career. In the following chapter a close reading of two songs reveals how different ways of responding to human suffering and death can be understood as different versions of a narrative ethics. «Ballad Of Hollis Brown» (1963) presents a narrative ethics through the representation of a specific human destiny. Identification and empathic involvment are revealed in the depiction of the tragic history of Hollis Brown and his family. «Blind Willie McTell» (1983), on the other hand, offers a narrative ethics that deals with human suffering on a different level, and where it is not the emotional involvement or identification that is called for. Instead the song stresses the need for a historical consciousness through a continuing involvement and evolvement of the musical tradition that is steeped in human suffering and death. The analysis underscores the importance of death as an ethical topic in the songwriting of the Nobel laureate.
\end{abstract}

Keywords: death, Bob Dylan, human suffering, narrative ethics

\section{Innleiing}

Døden går som ein svart tråd gjennom Bob Dylans songlyrikk. Frå debutplata i 1962 med sine dødsfikserte tradisjonelle bluessongar, via menneskeleg liding og død i protestsongar på 1960-talet til meditasjonar over eigen dødelegheit og forgjengelegdom på 1990-talet, for berre å ha nemnd tre opplagte døme. I dette kapitlet vil eg argumentere for at Dylan sine framstillingar av menneskeleg liding og død inneber ein narrativ etikk (Booth, 2002; Newton, 1995). Omgrepet narrativ etikk viser til at forteljingar presenterer oss for ulike etiske og moralske problemstillingar gjennom dei hendingane og karakterane som møter oss, og gjennom den haldninga som forteljaren og forteljinga syner fram. 
Gjennom nærlesingar av dei to songane «Ballad Of Hollis Brown» (1963) og «Blind Willie McTell» (1983) vil eg syne korleis menneskeleg liding og død for Dylan blir eit utgangspunkt for ei kunstnarisk handsaming der lyttaren blir presentert for moglege måtar å relatere seg etisk til døden på.

\section{Bob Dylan som historieforteljar i møte med døden}

Gjennom heile Bob Dylans karriere har menneskeleg liding og død stått sentralt for historieforteljaren Dylan. Alt i 1982 hevdar Michael Roos at døden er det berande temaet i Dylans tekstar (Roos, 1982), og eit seinare blikk på Dylans produksjon syner at døden aldri er langt unna, til dømes om vi tar eit blikk på Tempest, den siste plata som Dylan har gitt ut med eigenkomponerte låtar frå 2012, der han syng om drap og sjølvmord i «Tin Angel», om Titanics forlis i tittelmelodien og i ein elegi over John Lennon («Roll On John»). Og slik kunne vi halde fram med å gå gjennom Dylans katalog; døden er nærverande - som menneskeleg realitet og som historisk medvit.

Når eg i dette kapittelet vel å legge vekt på Dylan som historieforteljar i møte med døden, så er det fordi Dylan evnar å handsame døden på ein kompleks måte som gjer den etisk og estetisk relevant. Då Dylan på første halvdel av 1960-talet blei kjend som den store protestsongaren, stod tematisering av menneskeleg død sentralt i songar som «Masters Of War», «The Death Of Emmet Till», «The Lonesome Death Of Hattie Carroll». Men det som skil Dylan frå dei andre låtskrivarane på denne tida, er den kompleksiteten han skriv inn i songane. Alt i 1964 peika Tom Wilson, Dylans plateprodusent på fleire av 1960-talets mest kjende plater (frå The Freewheelin' Bob Dylan i 1963 til Bringing It All Back Home i 1965), på dette når han hevda at Dylan ikkje må forståast som ein snever protestsongar: «Those early albums gave people the wrong idea [...] Basically, he's in the tradition of all lasting folk music. I mean, he's not a singer of protest so much as he is a singer of concern about people» (Hentoff 1964, s. 17). To interessante moment blir uttrykt av Wilson i sitatet. Det første er at Dylan i større grad er ein songar som har omsorg for andre 
menneske, meir enn at han er ein protestsongar. Det andre er at Dylan står i ein folkemusikktradisjon, noko som gjer at musikken hans blir ein del av denne levande tradisjonen ved at den ikkje er statisk og eindimensjonal. Då Dylan blei tildelt Nobelprisen i litteratur i 2016, var det nettopp for hans poetiske nyskaping og utviding av den store amerikanske songtradisjonen. I eit intervju frå 1966 uttalar Dylan seg kritisk om såkalla protestsongar eller songar med ein klar politisk bodskap: «Songs like Which Side Are You On? And I Love You, Porgy - they're not folk-music songs; they're political songs. They're already dead» (Hentoff, 1966, s. 98). Dylans songar, sjølv dei som ofte blir rekna som protestsongar, har ein annan kvalitet enn dei fleste andre protestsongar frå 1960-talet. Som den anerkjende Dylan-fortolkaren Michael Gray skriv: «Dylan’s work has that clear integrity capable of «representing the age» and is competent, therefore, to go beyond it...» (2000, s. 2). I analysen av Dylans poetiske praksis i møte med døden står nettopp desse aspekta sentralt: at songane både uttrykkjer ein etikk av omsorg, og at songane står i forlenginga av den levande amerikanske folkemusikken.

\section{Narrativ etikk}

I kapitlet vil eg gi innblikk i korleis Dylan gjennom to av sine songar framstiller menneskeleg liding og død, og eg vil analysere songane ved hjelp av omgrepet narrativ etikk (narrative ethics). Innan litteraturvitskapen og narratologien (studiet av forteljingar i vid forstand) har ein sidan 1980talet snakka om den etiske vendinga eller tilbakevendinga, der etiske og moralske spørsmål blir sett som ein uunngåeleg del av det å lese litteratur (Lothe \& Hawthorn, 2013). Til dømes hevdar den amerikanske litteraturkritikaren Wayne C. Booth at forteljingar er våre viktigaste moralske læremeistrar (2001, s. 20). Ei av dei sentrale stemmene innan området, James Phelan, gir følgjande definisjon av omgrepet narrativ etikk:

Narrative ethics explores the intersections between the domain of stories and storytelling and that of moral values. Narrative ethics regards moral values as an integral part of stories and storytelling because narratives themselves implicitly or explicitly ask the question, «How should one think, judge, and act-as author, narrator, character, or audience - for the greater good?» (Phelan, 2014, s. 1). 
Som Phelan understrekar, inneber det å fortelje alltid etiske val i høve til kva ein fortel, kven ein vel å fortelje om, synsvinkel, ståstad og så bortetter. På same vis inngår lesaren eller lyttaren alltid i ein etisk relasjon med det fortalde.

I det følgjande vil eg lese «Ballad Of Hollis Brown» og «Blind Willie McTell» i lys av to ulike posisjonar innan narrativ etikk. Den første posisjonen er knytt til den kapasiteten litteratur og forteljingar har til å skildre etiske dilemma og til å gi ei framstilling av menneskeleg handling og liding slik at dei angår oss. Argumentet er knytt til at kunst og litteratur inneber ei skapande og biletskapande kraft som gjer at vi kan sjå andre menneske sine lidingar på ein særskilt måte ved at framstillinga skapar ein empati og sympati hos lesaren. Den amerikanske filosofen Richard Rorty peikar på dette i boka Contingency, Irony, and Solidarity:

In my utopia, human solidarity would be seen not as a fact to be recognized by clearing away 'prejudice' or burrowing down to previously hidden depths but, rather, as a goal to be achieved. It is to be achieved not by inquiry but by imagination, the imaginative ability to see strange people as fellow sufferers. Solidarity is not discovered by reflection but created. It is created by increasing our sensitivity to the particular details of the pain and humiliation of other, unfamiliar sorts of people. Such increased sensitivity makes it more difficult to marginalize people different from ourselves by thinking, 'They do not feel it as we would,' or 'There must always be suffering, so why not let them suffer?' (Rorty, 1989, s. xvi)

Menneskeleg solidaritet er ifølgje Rorty ikkje ein intellektuell prestasjon som er knytt til ei rasjonell erfaring. Tvert om er det noko som blir skapt gjennom ein auka sensitivitet overfor andre menneske sine lidingar, menneske som vi ikkje kjenner, men som gjennom imaginasjonen angår oss som felles lidande menneske (fellow sufferers), og ved at deira lidingar blir løfta fram og gitt ei historie og eit andlet. Rorty argumenterer for behovet for ei «kjenslemessig utdanning» (sentimental education) og hevdar at ei viktig årsak til at slaveriet blei oppheva i USA, var folkelesnaden av Harriet Beecher Stowes Onkel Toms hytte (1852).

Den andre posisjonen innan ein narrativ etikk kan knytast til mellom andre litteraturvitaren Adam Zachary Newton (1995), som er sterkt 
influert av Emmanuel Levinas sin etikk. Der den første posisjonen representert med Rorty ovanfor er opptatt av identifikasjon, sympati og litteratur som ei vektlegging av felles verdiar, løftar Newton fram ein narrativ etikk som nettopp søkjer å kome unna ei fiksering av den Andre i ein posisjon av identifikasjon. I Levinas sine termar vil dette innebere å gjere den Andre til det Same, å plassere andre menneske innanfor vår (eller ein) horisont av forståing. Newton nyttar vidare Levinas sine omgrep «det sagte» (the Said) og «sigen» (the Saying), der det sagte er eit språk som alt er uttrykt, og der den Andre er fiksert i tekst. Sigen, derimot, er den levande tale vend til eit du. For Newton må ein narrativ etikk nettopp undersøkje korleis den Andre og den Andres alteritet motset seg ei enkel og eintydig kategorisering gjennom eit levande språk (sigen) som ikkje enkelt lar seg underordne ei totaliserande forståing. Newton åtvarar difor mot ei framstilling av menneske som fikserte personar. Jamvel eit litterært univers med fiktive personar kan innebere ei problematisk avgrensing når forfattaren framstiller personar som bestemte karakterar i eit overordna plott, og der dei blir tvungne til å spele avgrensa roller. I staden løftar han fram litteratur som legg vekt på eit levande, tentativt språk der lesaren blir invitert inn i sjølve ytringa eller skriveakta. Som Liesbeth Korthals Altes skriv, inneber denne posisjonen å miste seg sjølv «in the submission to the call of the text as Other, and to lose the work as a graspable, coherent whole» (2008, s. 144).

Den vidare lesnaden vil vise korleis desse to perspektiva gir avgjerande fortolkingsnøklar til Dylans handsaming av døden.

\section{«Ballad Of Hollis Brown»}

Å velje ut to songar av Dylan om døden er krevjande. Når eg her vil legge vekt på to, så er det fordi «Ballad Of Hollis Brown» (1963) og «Blind Willie McTell» (1983) gir innblikk i korleis Dylan på svært ulikt vis tematiserer død. Der «Ballad Of Hollis Brown» er henta frå Dylans tid som «protestsongar», er «Blind Willie McTell» ein song som aldri kom med på studioalbumet Infidels (1983), men blei utgitt på ei samling av uutgitte songar i 1991 (The Bootleg Series, Vol. 1-3). Likevel er «Blind Willie McTell» i 
Dylan-resepsjonen blitt ståande som ein av dei mest anerkjende og analyserte songane hans.

«Ballad Of Hollis Brown» blei utgitt på albumet The Times They Are A-Changin' i 1964. Som tittelen speglar, er dette eit album gitt ut i ei brytningstid og der Dylan tematiserer borgarrettskampen, sosial urettferd m.m. Ifølgje Dylan sjølv så er «Ballad Of Hollis Brown» basert på ei sann historie han hadde lese i ei avis, utan at nokon har klart å stadfeste om dette stemmer. Men som han sjølv uttalte ein gong under introduksjonen av ein annan song basert i verkelege hendingar ( Who Killed Davey More»): «This is taken out of the newspapers. Nothing has been changed, except the words» (The Bootleg Series, Vol. 1-3).

Songen går i sin heilskap slik:

Hollis Brown

He lived on the outside of town

Hollis Brown

He lived on the outside of town

With his wife and five children

And his cabin fallin' down

You looked for work and money

And you walked a rugged mile

You looked for work and money

And you walked a rugged mile

Your children are so hungry

That they don't know how to smile

Your baby's eyes look crazy

They're a-tuggin' at your sleeve

Your baby's eyes look crazy

They're a-tuggin' at your sleeve

You walk the floor and wonder why

With every breath you breathe

The rats have got your flour

Bad blood it got your mare

The rats have got your flour 
Bad blood it got your mare

If there's anyone that knows

Is there anyone that cares?

You prayed to the Lord above

Oh please send you a friend

You prayed to the Lord above

Oh please send you a friend

Your empty pockets tell yuh

That you ain't a-got no friend

Your babies are crying louder

It's pounding on your brain

Your babies are crying louder now

It's pounding on your brain

Your wife's screams are stabbin' you

Like the dirty drivin' rain

Your grass it is turning black

There's no water in your well

Your grass is turning black

There's no water in your well

You spent your last lone dollar

On seven shotgun shells

Way out in the wilderness

A cold coyote calls

Way out in the wilderness

A cold coyote calls

Your eyes fix on the shotgun

That's hangin' on the wall

Your brain is a-bleedin'

And your legs can't seem to stand

Your brain is a-bleedin'

And your legs can't seem to stand

Your eyes fix on the shotgun

That you're holdin' in your hand 
There's seven breezes a-blowin'

All around the cabin door

There's seven breezes a-blowin'

All around the cabin door

Seven shots ring out

Like the ocean's pounding roar

There's seven people dead

On a South Dakota farm

There's seven people dead

On a South Dakota farm

Somewhere in the distance

There's seven new people born ${ }^{1}$

Tittelen refererer til at dette er ein ballade, men melodien og oppbygginga av strofene er klassisk blues gjennom gjentakinga av dei første linjene og det avsluttande omkvedet. Samstundes er songen ein ballade gjennom tredjepersonperspektivet (blues har alltid førstepersons perspektiv) og det tydelege narrative/forteljande plottet (Solberg, 2003). Fleire har peika på at songen er i slekt med den amerikanske murder ballad-tradisjonen, som igjen har røter i den europeiske balladetradisjonen (sjå t.d. Marqusee, 2007). Murder ballads er songar som skildrar eit drap, stundom ut frå mordarens synspunkt, stundom ut frå offerets. Ein meir tradisjonell litterær tradisjon som songen kan seiast å stå i slektskap med, er den litterære retninga naturalismen, som frå 188o-talet og framover brukte ein detaljert realisme for å skildre korleis sosiale forhold (ofte arbeidarmiljø og lågare klassar), arv og miljø er med og forme den menneskelege karakteren. Sentralt står førestillinga om at ytre faktorar blir determinerande menneska blir eit produkt av dei vilkåra dei lever under. Naturalismen la stor vekt på fysiologi, og forteljingane endar nesten alltid i død og undergang (Lothe, Refsum \& Solberg, 2007). Eit anna element ved naturalismen var intensjonen om å få forteljinga til å framstå som sann, noko som

1 Bob Dylans «Ballad Of Hollis Brown» (c) 1963 Warner Bros. Inc/1991 Special Rider Music. Henta frå: https://www.bobdylan.com/songs/ballad-hollis-brown/. Brukt i samsvar med sitatretten. Songteksten er ikkje omfatta av CC BY-NC 4.o-lisensen til boka, og kan ikkje bli gitt att utan løyve frå den som har rettane. 
innebar bruk av empirisk materiale, t.d. avisutklipp, tidsskrift m.m. slik at diktinga kunne fungere nærmast som ein sosiologisk analyse - ein klar parallell til fleire av Dylans songar der han knyter tematikkar til dagsaktuelle hendingar og spelar på dette, jamfør hans utsegn om at historia bak Hollis Brown er ei reell hending.

I det følgjande vil eg peike på korleis Dylan si framstilling skapar ein narrativ etikk i songen gjennom måten han byggjer opp forteljinga kring kompositoriske og narratologiske trekk som konflikt, karakter, synsvinkel m.m. Den grunnleggande konflikten i songen blir vi introdusert for allereie i første strofe: «Hollis Brown/He lived on the outside of town/ With his wife and five children/And his cabin fallin' down». Dette er den sentrale utfordringa som karakteren Hollis Brown står overfor. Dylans portrett viser at Brown brukar alle middel for å gjere det han kan i den situasjonen han er i. "You looked for work and money/And you walked a ragged mile». Det er ikkje Brown sin karakter som gjer at han til slutt endar med å ta livet av familien og seg sjølv, men som i naturalismen er det dei ytre vilkåra som tvingar han til det: utan arbeid, ingen pengar, ingen vennar, ein fråverande Gud, og ein situasjon der naturen også er fiendtleg: hesten er død, mjølet er tatt av rotter, vatnet er vekke, og graset har visna: "Your grass is turning black». Og som i naturalismen har historia berre éin mogleg utgang, undergangen, noko som alt blir signalisert i frampeiket i første strofe: «And his cabin fallin' down».

Eit anna særmerkt kjenneteikn er korleis vi følgjer Hollis Brown heile vegen fram mot undergangen gjennom den spenninga og nerven som teksten presenterer gjennom eit biletskapande og fortetta språk som byggjer opp under det aukande presset som Hollis Brown står overfor. I strofe tre høyrer vi korleis auga til spedbarnet fysisk nappar i ermet til Brown. Denne sterke fysiske skildringa blir vidare utvikla i strofe seks der barnas skrik «It's pounding on your brain» og konas skrik knivstikk han. Eit anna aspekt ved denne strofa er koplinga mellom barna og konas skrik og regn. Barnas skrik er "pounding» - som kan sjåast som eit byrjande regn, medan i dei to siste verselinjene har skrika blitt til «dirty drivin' rain». Denne metaforen eller samanlikninga blir tatt opp og vidareutvikla i strofe ti når hagleskota lyder «Like the ocean's pounding roar». Det er demninga og Hollis Brown som brest - det byrjande regnet via det drivande regnet endar i flom. 
Vidare er her fleire andre kompositoriske trekk som underbyggjer stemninga. Strofe sju endar med at Brown brukar den siste dollaren på sju hagleskot, og sjølv om talet sju ikkje er nemnt tidlegare, veit vi at dette utgjer Brown, kona og dei fem barna. Strofa blir etterfølgd av ei strofe der ula frå ein coyote ytterlegare blir ein frampeikar mot det som skal kome: «Way out in the wilderness/A cold coyote calls». Dylan har sjølv nytta eit liknande bilete i ein seinare apokalyptisk song, «All Along The Wathctower»: «Outside in the distance a wildcat did growl». Ei svært effektfull utvikling i Browns ferd mot undergangen skapar Dylan i strofe åtte og ni når spranget frå å sjå hagla på veggen til at Brown held henne i handa, skjer nærmast umedvite eller i transe: «Your brain is a-bleedin'/And your legs can't seem to stand/Your eyes fix on the shotgun/That you're holdin' in your hand».

Heile teksten byggjer opp under ei klaustrofobisk kjensle, som blir forsterka av den monotone bluesen der hendingane blir gjentekne i kvart vers, at handlinga går føre seg i presens (vi er der når det skjer), og gjennom ein utstrakt bruk av allitterasjon som er med å byggje opp under ein suggererande effekt, t.d. «dirty, drivin' rain», «last lone dollar», «seven shotgun shells», «a cold coyote calls». Til saman skapar dette ei fortetta stemning der tilhøyraren ikkje slepp unna.

For Dylan blir Browns ferd mot undergangen eit høve til å uttrykkje ein allmennmenneskeleg situasjon - dette gjeld ikkje berre Hollis Brown og familien, men er ein kontinuerleg syklus: «Somewhere in the distance/ There's seven new people born». Her ligg ein klar parallell til Dylans spørsmål i «Blowin’ In The Wind»: «... how many years can some people exist/Before they're allowed to be free?»

Eit anna moment er korleis Dylan brukar namnet Hollis Brown og fleire andre symbol som kan underbyggje ei slik fortolking av ein allmennmenneskeleg situasjon. Brown er eitt av dei vanlegaste etternamna i USA, på linje med Jones, og Dylan har sjølv brukt etternamnet Jones som ein generell karakter $\mathrm{i}$ «Ballad Of A Thin Man» (1965) når han syng: «Do you, Mister Jones?» Og i antikrigssongen «John Brown», som Dylan skreiv i 1962, står John Brown som representant for den alminnelege soldat. Når Dylan nyttar etternamnet Brown, er det ei opplagt tolking at det kan lesast som den alminnelege mann. Hollis, derimot, er etymologisk 
knytt til heilag (holy), og betyr han som bur nær heilage buskar, wholy/ holly bushes, altså kristtorn, som i folketradisjonen blei rekna som heilage. Hollis Brown blir dermed den alminnelege heilage mann. Han blir ein omvend Kristus-figur som går til grunne i møte med eit samfunn som lar han gå til grunne. Fleire moment i songen kan lesast i tråd med ei slik tolking: Sentralt i songen står det heilage talet sju. Sjølv om Dylan hevdar dette er ein song basert på ei sann historie, verkar det ikkje tilfeldig, men snarare intendert at Brown og familien utgjer sju medlemmer. For dramatisk effekt kunne Dylan ha introdusert fleire barn, men fem passar inn i numerologien. Talet sju blir først uttalt i strofe sju. Og deretter blir det gjentatt seks gongar. Til saman sju gongar blir talet sju uttalt. Sju gongar sju er 49. I antikken var talet sju det ein rekna menneskealderen etter, og når ein var nådd sju gongar sju år, altså 49, gjekk det berre éin veg. 49 blei talet for der livet snudde (Kirk, 1995).

Den narrative etikken i «Ballad Of Hollis Brown» er knytt til framstillinga av den alminnelege, men samstundes heilage mann, forstått som ein av oss som ikkje blir anerkjend eller verdsett som det, og som går til grunne i Sør-Dakota, i ein konkret setting, utan at nokon er der og hjelper han. Som Dylan syng: «If there's anyone that knows/Is there anyone that cares?» I songen er der ingen som bryr seg, og lyttaren må følgje Hollis Brown og familien sin veg ned i avgrunnen utan å kunne gjere noko. Men den manglande omtanken som Hollis Brown møter i songen, skapar ein empati hos tilhøyraren som sjølv må svare på spørsmålet «Is there anyone that cares?» Det blir lyttarens oppgåve å gjere noko med dette, Dylans oppgåve er fullført gjennom forteljinga om Hollis Brown.

I lesnaden ovanfor ser eg «Ballad Of Hollis Brown» som ein song som plasserer seg innan ein narrativ etikk slik Richard Rorty etterspør den. Det er ein identifikasjon med Brown og hans lidingshistorie der Dylan vender seg til han gjennom det personlege pronomenet «du» frå strofe to og utetter. Heile songens oppbygging er meint å resultere i ein sympati hos ein lesar som lar seg bevege av Browns lagnad. Men det er òg ein identifikasjon med den evige menneskelege lidinga som blir gitt eit namn og ei historie. Som den franske filosofen Paul Ricoeur skriv, handlar dette om: «... the necessity to save the history of the defeated and the lost. The whole history of suffering [...] calls for narrative» (1984, s. 75). 


\section{«Blind Willie McTell»}

Trass i at Dylan aldri fann plass til «Blind Willie McTell» på ei studioplate, har songen blitt rekna som eit meisterverk i Dylans katalog, noko som òg har sett sine tydelege spor i Dylan-resepsjonen. Få songar har blitt gjenstand for så grundige analysar som nettopp «Blind Willie McTell» (sjå t.d. Ricks, 2003; Gray, 2000, 2006; Wilentz, 2005 for gode lesnader, og i Noreg har Mollerin, 2007 og Selnes, 2016 levert grundige analysar). I denne samanhengen er det uråd å yte dei ulike lesnadene rettferd; mitt fokus vil vere på korleis songen opnar for ei handsaming av døden som kan knytast til ein ganske annleis posisjon enn det Dylan gjer i «Ballad Of Hollis Brown». Men først teksten i sin heilskap:

Seen the arrow on the doorpost

Saying, 'This land is condemned

All the way from New Orleans

To Jerusalem'

I traveled through East Texas

Where many martyrs fell

And I know no one can sing the blues

Like Blind Willie McTell

Well, I heard that hoot owl singing

As they were taking down the tents

The stars above the barren trees

Were his only audience

Them charcoal gypsy maidens

Can strut their feathers well

But nobody can sing the blues

Like Blind Willie McTell

See them big plantations burning

Hear the cracking of the whips

Smell that sweet magnolia blooming

See the ghosts of slavery ships

I can hear them tribes a-moaning

Hear that undertaker's bell 
Nobody can sing the blues

Like Blind Willie McTell

There's a woman by the river

With some fine young handsome man

He's dressed up like a squire

Bootlegged whiskey in his hand

There's a chain gang on the highway

I can hear them rebels yell

And I know no one can sing the blues

Like Blind Willie McTell

Well, God is in His heaven

And we all want what's his

But power and greed and corruptible seed

Seem to be all that there is

I'm gazing out the window

Of the St. James Hotel

And I know no one can sing the blues

Like Blind Willie McTell ${ }^{2}$

Songen opnar med ei pil i ein dørkarm, som uttrykkjer at dette landet er fordømt, eit land som strekker seg frå New Orleans til Jerusalem. Slik rommar songen både dei amerikanske sørstatane og Jerusalem, kanskje den mest mytologiske av alle stader, og slik koplar Dylan slaveriets historie med israelfolkets, den nye og den gamle verda, og gjer dette til ein song over den menneskelege lidingshistoria. Dette blir ytterlegare forsterka av at Dylan i mange liveversjonar har sunge «All the way from New Orleans to New Jerusalem», noko som vidarefører den menneskelege lidinga inn i ei fjern framtid til det himmelske Jerusalem. Gjennom dei fem strofene blir vi presenterte for ulike scenario som i hovudsak er knytte til slaveriets historie i sørstatane. Vi høyrer om martyrar som fall i Aust-Texas i strofe ein, og Michael Gray (200o) har peika på at Aust-Texas

2 Bob Dylans «Blind Willie McTell» (C) 1983 Special Rider Music. Henta frå: https://www.bobdylan com/songs/blind-willie-mctell/. Brukt i samsvar med sitatretten. Songteksten er ikkje omfatta av CC-BY 4.o-lisensen til boka, og kan ikkje bli gitt att utan løyve frå den som har rettane. 
var eit kjerneområde for Ku Klux Klan, og Sean Wilents (2010) har understreka at fleire byar i sørstatane ber namnet Jerusalem, m.a. byen der slaveopprøraren Nat Turner blei hengd i 1831. Vidare høyrer vi i strofe tre om plantasjar som brenn, om lyden av piskeslag, slaveskip og klaging frå stammane. Ved sidan av augeblikksbilete frå slaveriets historie (som også kan lesast som ein del av israelfolkets historie - jamfør Jerusalem og omtalen av stammar, som kan lesast både som afrikanske stammar og Israels tolv stammar) - verkar strofe to å handle om eit omreisande show der ein mannleg artist (McTell) berre blir høyrt av stjernene. I den nest siste strofa blir vi nok ein gong presentert for bilete frå sørstatane gjennom lenkegjengar og opprørsrop. Den siste strofa endar med å slå fast at Gud er fjern i sin himmel, og at alt som er på jorda, er makt og grådigheit. Songar-eget endar med å stire ut av vindauget på St. James Hotel. Samstundes: Gjennom alle dei fem strofene i songen har vi fått høyre at ingen kan synge blues som Blind Willie McTell.

Ifølgje den anerkjende Dylan-skribenten Michael Gray (2006) tematiserer «Blind Willie McTell» det menneskelege dilemmaet det er å vitne og å konfrontere menneskeleg død generelt, snarare enn den individuelle. Det er lett å støtte denne vurderinga, og slik skil songen seg markant frå strategien i «Ballad Of Hollis Brown». Som Ian Bell skriv: «At no point in «Blind Willie McTell» is the listener's sympathy or tears demanded» (2015: 281). Det er ikkje ein identifikasjon med ein konkret menneskeleg lagnad som Dylan legg opp til, men eit historisk medvit over den menneskelege lidinga. Men kven er Blind Willie McTell, og kva gjer han i songen, korleis skal vi lese forholdet mellom Dylan og McTell, og kva signaliserer pila i dørkarmen?

Blind Willie McTell (1898-1959) var ein svart amerikansk bluesartist, kjend som ein eminent gitarist, songar og komponist og som bevegde seg i mange ulike sjangrar ved sidan av blues, som ragtime, religiøse songar m.m. (Wilentz, 2010). Jamvel om McTell hadde ein lang karriere og gav ut fleire album på ulike plateselskap, fekk han aldri eit større gjennombrot og døydde alkoholisert og relativt ukjend. Men kvifor er det nettopp McTell som er den artisten som Dylan insisterer på er unik, og som her blir ståande som den som kan synge ein elegi over menneskeleg liding? Fleire har lagt vekt på at McTell ikkje var ein typisk tradisjonell 
bluesartist, men ein fornyar og modernist som sprang ut av tradisjonen, ein klar parallell til Dylan sjølv (Bell, 2015; Selnes, 2016; Wilentz, 2010). Heller ikkje var McTell ein songar som tematiserte urettferd mot svarte. Ifølgje Selnes er det nettopp det store kreative spennet til McTell (som hos Dylan) som gjer han eigna til å fylle rolla som sannseiar eller sanningsvitne i songen, at han ikkje er redusert til ein type, eller ein songar med ein eintydig bodskap. Eg er samd i det, og eg vil hevde at slektskapen mellom McTell og Dylan er sentral gjennom heile songen alt frå første linja med pila i dørkarmen. Mange har knytt pila i dørkarmen til ulike jødiske samanhengar som lammets blod, pogromar m.m. (Gray, 2000; Mollerin, 2007; Wilentz, 2010), og dette er ein relevant lesnad. Men i min lesnad utgjer pila den opplagte koplinga mellom McTell og Dylan. Jamvel om Selnes er inne på tanken om at pila kan vere ei bodstikke, slår han den raskt frå seg og les pila primært som eit symptom på ufred meir enn som eit symbol. Men om vi ser pila som ei bodstikke, kven er ho frå, om ikkje McTell sjølv? Fleire har peika på at songen handlar om å sjå, noko som blir gjentatt gjennom heile songen: «seen the arrow», «see them big plantations burning», "gazing out the window». Men vel så mykje er dette ein song om ei stemme gjennom det å synge («nobody can sing the blues like...») og det å fortelje. Og i songen er McTell det syngande subjektet som indirekte fortel om den menneskelege lidinga som diktar-eget ser i dei ulike strofene.

Dette syner Dylan sitt meisterskap i å skrive fram og synge fram menneskeleg liding utan å freiste ein umogleg identifikasjon med historias offer. Når Newton (1995) i sin narrative etikk åtvarar mot ei kvar form for fiksjonalisering av menneske, nettopp fordi det inneber ei fiksering av andre, løftar han i staden fram ein narrativ etikk der sigen er eit levande språk som opnar for at verda stendig må skapast på ny. Fleire har peika på at McTell er ein variant av den arketypiske blinde sjåaren, men få har lagt vekt på McTell som ein forteljar gjennom etternamnet (Mollerin, 2007 nemner rett nok dette utan at det blir gjort eit større poeng ut av det). Når Dylan nettopp har vald Blind Willie McTell som karakter i songen, så er namnet ei opplagd årsak i ein song som handlar om å halde songen levande i møte med lidingshistoria. Slik kan pila i dørkarmen sjåast som ei pil sendt ut frå McTell sin boge/gitar (Selnes, 2016). At det er McTell som 
har sendt bodskapen, må også lesast ut frå at McTell er den einaste som har ei stemme i songen - forutan ugla som også blir kopla til McTell både som klokskap og ulukkesvarsel i strofe to (legg merke til korleis «Were his only audience» kan vise til både ugla og McTell). Og om vi ser pila som ei bodstikke, så er det opplagt at det er Dylan eller songaren som er mottakaren. Bodstikka er ikkje berre ein bodskap, men er meint å bringast vidare (tidlegare heitte t.d. stafettløp bodstikkeløp). Og kva for ein bodskap er det songaren/Dylan blir beden om å bringe vidare? Det er nettopp den levande songen og forteljinga. Kvart vers blir avslutta med oppmodinga om å fortelje (McTell). Og dette blir verkeleg hamra inn i siste strofe der songaren/Dylan stirer ut av vindauget på St. James Hotel (uttalt tell) og slik oppnår ei dobbel gjentaking og oppmoding om å fortelje. Det er neppe tilfeldig at dette blir uttalt etter at songar-eget er plassert på eit hotellrom som ein omreisande trubadur lik McTell. Det er ei oppmoding om ei forteljakt som må sjåast i lys av ein narrativ etikk som vil unngå ei overflatisk framsyning av menneskeleg liding, men som er knytt til eit historisk medvit om kva songen og tradisjonen spring ut av (Bell, 2015); den amerikanske songtradisjonen som direkte er knytt til slaveriets historie, og som både McTell og Dylan er ein del av. Slik blir dette ein song som syner det umoglege i ein identifikasjon med historias offer, men at songen likevel må halde fram og syngast på ny. Heller ikkje er dette ein identifikasjon med McTell, men med sjølve den skapande akta som McTells song og kunstnariske praksis inneber. Den levande songen blir ei etisk handsaming av menneskeleg liding og død; ikkje som enkel tematisering, men som kontinuerleg kunstnarleg aktualisering. Den franske forfattaren Maurice Blanchot argumenterer for ei slik form for estetikk når han hevdar: "The tale is not the narration of an event, but the event itself, the approach to that event, the place where the event is made to happen - an event which is yet to come and through whose power of attraction the tale can hope to come into being too» (Blanchot, 1982, s. 447).

\section{Avsluttande kommentar}

I analysen av «Ballad Of Hollis Brown» og «Blind Willie McTell» har eg vist korleis dei to songane er uttrykk for to ulike etiske posisjonar i Dylans 
handsaming av døden. «Ballad Of Hollis Brown» legg opp til ein identifikasjon og ein empati med protagonisten Hollis Brown. I framstillinga av Browns veg mot undergangen nyttar Dylan eit biletrikt og fortetta språk som gjer at lyttaren blir gjort ansvarleg i møte med enkeltindividets lagnad. Ein liknande narrativ etikk har Dylan nytta seg av i andre songar om menneskeleg død, til dømes «The Lonesome Death Of Hattie Carroll» (1964) og «Hurricane» (1975). Songane er meint å skape ein reaksjon og ein respons hos lyttaren gjennom framstillinga av konkrete menneskelege lagnadar. Samstundes er dette ein posisjon som primært kan knytast til Dylans tidlege karriere, og Dylan har sjølv ytra seg kritisk om musikkens etiske potensial, til dømes i boka Tarantula, når han skriv: «this land is my land \& this land is your land - sure - but the world is run by those who never listen to music anyway» (1966/1971). I lesnaden av «Blind Willie McTell» har eg synt korleis Dylan tar ein heilt annan posisjon i møte med menneskeleg død som kan lesast i lys av sitatet frå Tarantula. På mange måtar er det ei resignert framstilling der den menneskelege lidingshistoria blir løfta fram utan løysing eller ei form for katarsis hos lyttaren. Dylans svar på dette dilemmaet blir i «Blind Willie McTell» å tematisere den menneskelege lidinga, utan å ty til ei identifisering med offera. I staden løftar han fram den amerikanske songtradisjonen gjennom Blind Willie McTell som ein representant som kan synge og fortelje den menneskelege lidinga; og der Dylan plasserer seg som ein tradisjonsberar og tradisjonsfornyar med eit ansvar. I dette ligg det ein narrativ etikk som handlar om eit historisk og tradisjonshistorisk medvit der lyttaren og songaren stadfestar songen og held minnet om lidingshistoria levande.

Analysene av «Ballad Of Hollis Brown» og «Blind Willie McTell» har vist korleis døden for Dylan blir noko som krev ein identifikasjon med menneskeleg liding, samstundes som han viser det umoglege i det same. Slik syner Dylan fram døden som ein kompleks og mangetydig menneskeleg realitet som tvingar fram ein kontinuerleg etisk og estetisk respons.

\section{Referansar}

Korthals Altes, Liesbeth (2008). Ethical turn. I D. Herman, M. Jahn \& M.-L. Ryan (Red.), Routledge Encyclopedia of Narrative Theory (s. 359-36o). London: Routledge. 
Bell, Ian (2015). Time Out of Mind: The Lives of Bob Dylan. London: Pegasus Books. Blanchot, Maurice, \& Josipovici, Gabriel (1982). The Sirens' Song: Selected Essays of Maurice Blanchot. Bloomington: Indiana University Press.

Booth, Wayne Clayson (2001). Why ethical criticism can never be simple. I T. F. Davis \& K. Womack (Red.), Mapping the Ethical Turn: A Reader in Ethics, Culture and Literary Theory (s. 16-29). Charlottesville: University Press of Virginia.

Dylan, Bob (1963). Ballad Of Hollis Brown. Henta frå https://bobdylan.com/songs/ ballad-hollis-brown/ (lasta ned 10.01.2018).

Dylan, Bob (1966/1971). Tarantula. New York: Scribner.

Dylan, Bob (1983). Blind Willie McTell. Henta frå https://bobdylan.com/songs/ blind-willie-mctell/ (lasta ned 10.01.2018).

Dylan, Bob (1991). The Bootleg Series, Vol. 1-3 (Rare \& Unreleased) 1961-1991. Columbia Records.

Gray, Michael (200o). Song \& Dance Man III: The Art of Bob Dylan. London: Continuum.

Gray, Michael (2006). The Bob Dylan Encyclopedia. London: Continuum.

Hentoff, Nat (1964). «The crackin', shakin', breakin', sounds» by Nat Hentoff, The New Yorker, October 24, 1964. I J. Cott (2007), Dylan on Dylan: The Essential Interviews (s. 13-28). London: Hodder \& Stoughton.

Hentoff, Nat (1966). Interview with Nat Hentoff, Playboy, March 1966. I J. Cott (2007), Dylan on Dylan: The Essential Interviews (s. 93-111). London: Hodder \& Stoughton.

Kirk, Henning (1995). Da alderen blev en diagnose. København: Munksgaard.

Lothe, Jakob, Refsum, Christian, \& Solberg, Unni (2007). Litteraturvitenskapelig leksikon. Oslo: Kunnskapsforlaget.

Lothe, Jakob, \& Hawthorn, Jeremy (Red.) (2013). Narrative Ethics. Amsterdam: Rodopi.

Marqusee, Mike (2007). Den onde budboreren: Bob Dylan og sekstitallet. Oslo: Oktober.

Mollerin, Kaja Scherven (2007). På St. James Hotel. Agora, nr. 1-2, 126-150.

Newton, Adam Zachary (1995). Narrative Ethics. Cambridge, MA: Harvard University Press.

Phelan, James (2014). Narrative ethics. I P. Hühn et al. (Red.), The Living Handbook of Narratology. Hamburg: Hamburg University. Henta frå http://www.lhn.unihamburg.de/article/narrative-ethics (lasta ned 10. november 2017).

Ricks, Christopher (2003). Dylan's Visions of Sin. London: Viking.

Ricoeur, Paul (1984). Time and Narrative, Volume 1. Chicago: University of Chicago Press. 
Roos, Michael (1982). Fixin' to die: The death theme in the music of Bob Dylan. Popular Music \& Society, 8(3-4), 103-116.

Rorty, Richard (1989). Contingency, Irony, and Solidarity. Cambridge: Cambridge University Press.

Selnes, Gisle (2016). Den store sangen: kapitler av en bok om Bob Dylan. Oslo: Vidarforlaget.

Solberg, Olav (2003). Norske folkeviser: våre beste ballader. Oslo: Aschehoug. Wilentz, Sean (2010). Bob Dylan in America. New York: Doubleday. 



\title{
«Eg veit i himmerik ei borg» og «Eg ser». Metaforar i salmar brukte i gravferder
}

\author{
Norunn Askeland \\ Universitetet i Søraust-Noreg
}

\begin{abstract}
Summary: What metaphors about life, death and afterlife is found in hymns often sung in funerals? In order to get an historical perspective on this issue I analyse and compare the metaphors in two hymns, one popular hymn from the Middle Ages, translated from German to Norwegian, and one popular hymn from the 1980's, written by a Norwegian priest and pop artist. Both hymns portray life as a journey for a poor wanderer and his companion. The companion in the oldest hymn is with no doubt Christ, whereas the companion in the modern hymn can be Christ or another human being, depending on the context. Death is personified as a violent person in the oldest hymn and as something you have to taste in the modern hymn. The hymn from the Middle Ages portray life after death as living with Christ in a castle of gold in eternal joy in heaven, whereas the modern hymn does not mention heaven at all. The main metaphor in the oldest hymns is the castle of gold, maybe as a result of the fact that Germans in the Middle Ages all had a castle in the mountains before their eyes. The main metaphor in the modern hymn is Understanding is Seeing, as the life companion cannot do anything but see the wanderer's trouble and share it with him. This is compared to how modern Scandinavian priests in hospices talk to dying patients: they cannot talk about heaven directly in their own words, but they can follow the patients' thoughts about heaven. In this way the modern hymn is a symptom of a typical secularized society.
\end{abstract}

Keywords: afterlife, death, funerals, hymns, metaphors

\section{Innleiing}

I løpet av hausten 2017 var eg i to gravferder. Begge var i kyrkjeleg regi, der det vart sunge salmar, og i begge gravferdene song dei denne salmen, som begynner slik: «Eg veit i himmerik ei borg, ho skin som soli klåre». Den første gravferda var i ei fjordbygd på Vestlandet, og den andre var på vestkanten i Oslo. Dei gravlagde var høvesvis ei bondekvinne på 97 år og ein mannleg språkforskar på 75 år. Den første var truande kristen,

Sitering av denne artikkelen: Askeland, N. (2018). «Eg veit i himmerik ei borg » og «Eg ser». Metaforar i salmar brukte i gravferder. I A. Johannessen, N. Askeland, I. B. Jørgensen \& J. Ulvestad (Red.), Døden i livet (Kap. 2, s. 35-50). Oslo: Cappelen Damm Akademisk. https://doi.org/10.23865/noasp.40.ch2

Lisens: CC BY-NC 4.0 
den andre ikkje-truande ateist. Dei mange som var møtte fram, kunne salmen og song så det ljoma i begge gravferdene. Etter dette har salmen sunge seg sjølv inne i meg, sikkert på grunn av den vakre folketonen, men kanskje også fordi eg har sett den skinande borga i himmelen for mitt indre auge, takka vere metaforen i dei to første linjene i teksten. Slik vart eg inspirert til å sjå nærmare på metaforane i denne gamle salmen og om mogleg samanlikne dei med metaforane i ein annan og nyare salme.

Dette kapitlet skal med andre ord handle om metaforar i salmar brukte i gravferder. Eg vil ta for meg salmen «Eg veit i himmerik ei borg» frå før 1600, og samanlikne han med salmen «Eg ser» av Bjørn Eidsvåg frå 1983. Utvalet av salmar kan verke tilfeldig og intuitivt ved første augnekast, men gjennom samtalar med kollegaer og venner har eg fått stadfesta at desse salmane er i bruk i gravferder. Resultata frå analysen kan naturlegvis ikkje generaliserast til å gjelde alle salmar. Grunnane til at desse to salmane er utvalde til analyse, er for det første at begge salmane er i bruk i gravferder i dag. For det andre har salmane ulik alder, i og med at det er rundt 400 år mellom dei. Det er derfor truleg at metaforane og tenkjemåten om livet, døden og eit eventuelt liv etter døden vil vere ulik i dei to tekstane. Ikkje minst fordi ein del forsking tyder på at tenkjemåten om livet, døden og særleg livet etter døden har endra seg over tid. Vi begynner med det siste.

\section{Bakgrunn og problemstilling}

Kva er vanlege førestillingar om livet etter døden i dag? Førsteamanuensis i teologi Bjarte Leer-Salvesen har funne at himmelen eller etterlivet er til stades i prestars forkynning i norske gravferder, men at det som blir sagt om emnet, er lite konkret (Leer-Salvesen, 2011). Professor i religionssosiologi Pål Repstad hevdar at det generelt er feelgood meir enn frykt som pregar kristne forkynnarstrategiar i dagens kristenliv, og at det i dag er svært få som trur at menneske anten blir frelste eller går fortapt når dei døyr (Repstad, 2015). Det han slår fast, er at mange er usikre på kva som skjer etter døden, og at førestillinga om evig fysisk pine nærmast er borte. Kristendommen er med andre ord blitt mjukare, og Repstad peikar på ei rekkje forhold som kan ha svekt trua på helvete og fortaping, blant anna 
antiautoritære ideal, religionsdialog, toleranse, auka utdanning og mindre interesse for teologi. Han hevdar også at folkeleg kristendom i tidlegare tider har vore mjukare enn den omvendingspredikantar presenterte i det han kallar «pietismens gylne århundre», frå om lag 1870 til 1970. For å illustrere dette poenget deler han ein anekdote med lesaren:

Jeg minnes en historie fra lyngdalstraktene, der den lokale møteleder prøvde å glatte ut litt etter den omreisende predikants helvetestale: «Ja, dette var alvorlige ting. Men nå skal me ha et grann kaffi, så ser me kanskje lysere på det.» (Repstad, 2015, s. 72)

Førestillinga om evig fysisk pine var ei konkret førestilling, men ifølgje Repstad vart forkynninga meir abstrakt frå slutten av 1950-åra, og det vart understreka oftare at fortapinga var biletleg tale og forstått som eit liv utan Gud.

Ein ting er helvete, men kva med himmelen? Dei to danske prestane Birgitte Stimpel og Ole Raakjær (Stimpel \& Raakjær, 2016) gjer i artikkelen «Himlen, der forsvandt» greie for ein studie av danske prestar på sjukehus og hospice og deira måte å samtale med pasientar og pårørande om blant anna himmelen og eit liv etter døden. Det viser seg at prestar og lekfolk kan ha ulike tilnærmingar til himmelen. Teologar har hatt ei teosentrisk tilnærming, det vil seie at dei er mest opptekne av at ein kan få sjå Gud etter døden. Mens lekfolk har tenkt ut frå ein meir antroposentrisk modell, som handlar om å møte igjen sine kjære i himmelen. Desse motsetningane er brotne ned i det tjuande hundreåret, og dermed blir det tradisjonelle biletet av himmelen som stad løyst opp, og det kristne håpet blir plassert $\mathrm{i}$ «det evige nu» (Stimpel \& Raakjær, 2016, s. 21). To av prestane som vart intervjua, tvilte på om dei i det heile kunne seie noko om himmelen, og spørsmålet om korleis himmelen ser ut, vert oppfatta som eit avansert spørsmål, der ein må skilje mellom private, emosjonelle metaforar og fornuftsbaserte tankar. Alle prestane var skeptiske til den antroposentriske oppfatninga av himmelen som ein stad å møte sine kjære. Prestane var likevel opptekne av at det var pasientane som skulle setje dagsordenen, og var villige til å gå inn i ein medmenneskeleg samtale om himmelen som stad med pasienten. Himmelen blir då nærmast eit symbol på kontakten, og det er dei kristne rituala og språket i dei 
som snakkar himmelen fram. Begge partar veit like lite om himmelen, og denne mangelen på kunnskap utgjer ei bru mellom partane og gjer at dei begge blir medvandrarar. Sjølv om presten ikkje trur på himmelen som stad, blir han medtruande i samtalar der pasienten trur på det: «Tro på himmel og evighed synes at være et «mellemværende», en hændelse, der opstår i mødet snarere end en essens eller indre kerne» (Stimpel \& Raakjær, 2016, s. 25).

Så langt om bakgrunnen for emna, liv, død og livet etter døden, men kvifor studere metaforar om dette? Ein ting er at både livet og døden i seg sjølv er konkrete fenomen i den forstand at vi kan observere om ein person lever eller er livlaus. Men måten vi oppfattar liv og død på, kan vere metaforisk. Uansett vil himmelen og det eventuelle livet etter døden i vår tid vere meir abstrakt eller kanskje eit biletleg fenomen. Då kan det hende at ein metaforanalyse kan gjere både liv, død og livet etter døden meir konkret for oss og samtidig fortelje noko om korleis salmediktaren har tenkt om desse emna.

Eg vil derfor analysere metaforbruken i desse to tekstane med utgangspunkt i følgjande spørsmål:

1) Kva for metaforar er brukte om livet, døden og livet etter døden i «Eg veit i himmerik ei borg» og «Eg ser»?

2) Kva for førestillingar og tenkjemåtar gjev metaforane uttrykk for?

3) Er det skilnad på metaforbruk og tenkjemåte om livet, døden og livet etter døden i dei to salmane?

Før eg presenterer materialet for analyse, som er dei to salmane, vil eg gjere kort greie for det teoretiske fundamentet for analysen.

\section{Tidlegare forsking om metaforar om livet, døden og livet etter døden}

Metaforar er måtar å gjere det abstrakte eller ukjende meir konkret gjennom å samanlikne det ukjende eller abstrakte med det kjende og konkrete. Det vi samanliknar med, kallar vi kjeldeområdet, mens det vi omtaler, er målområdet (Lakoff \& Johnson, 1980; Lakoff \& Turner, 
1989). Kjeldeområdet er som oftast konkret og kjent, mens målområdet er meir abstrakt eller ukjent. Slik sett kan vi seie at ein metafor består av koplinga mellom to konseptuelle område, til dømes koplinga mellom målområdet livet og kjeldeområdet årstidene, der vår står for barndom og ungdom, sommar står for vaksenliv, mens haust og vinter står for alderdom. Til dømes er det vanleg å omtale både livet og døden som ei reise. Døden kan sjåast på som ein slutt på reisa eller som avgang for ny reise. Vidare blir livet ofte samanlikna med ein dag og døden med ei natt, der livet er lys og døden mørke. Livet blir også samanlikna med eit år, der årstidene utgjer ulike aldrar i menneskelivet. Vidare kan livet vere framstilt som trældom, og døden som ein frigjerande søvn. I tillegg kan døden samanliknast med eller framstillast som ein person, som t.d. mannen med ljåen, som meiar ned menneske som om dei skulle vere gras. Mennesket blir då samanlikna med ein plante eller til og med eit tre, som har røter, greiner og bladverk. Livet etter døden finst det òg forsking om, blant anna gjort greie for i eit kapittel i denne boka (Johannesen \& Askeland, 2018). Her ser vi at døden kan forståast som inngangen til ei ukjend verd, som porten til ein lysande himmel eller som ein evig søvn i pastellfargar. Det finst òg forsking om metaforar om helvete og fortaping, men det er mindre relevant for mitt materiale i dette kapitlet.

Som forskingsspørsmåla implisitt gjev uttrykk for, er det kognitiv og diskursorientert metaforteori som er grunnlaget for analysen (Lakoff \& Johnson, 1980; Semino, 2008; Steen, 2010). Dette er teoriar som går ut frå at det er ein samanheng mellom metaforane vi bruker, og måten vi tenkjer på. Om vi skildrar Gud eller Jesus som konge og brudgom, tenkjer vi for det første at livet etter døden handlar om rikdom, velstand og makt. For det andre ligg det implisitt $i$ tenkjemåten vår at Gud er mann og ikkje kvinne. At dette siste er det vanlegaste i siste utgåva av Norsk salmebok, vart grundig dokumentert av stipendiat i religionsvitskap Hanne Stenvaag då salmeboka sist vart revidert i 2013 (Stenvaag, 2013). Ho fann berre fire salmar som hadde kvinneleg gudsbilete, der Gud var omtalt som mor.

Hjernen vår er så å seie litterær på den måten at vi kan både skape og forstå komplekse konstruksjonar som forteljingar, likningar og metaforar. 
Det er dette som er grunnlaget for at vi i det heile kan lære språk, hevdar Mark Turner (Turner, 1996; 2006). Den metaforiske tenkinga er då grunnlaget for det menneskelege medvitet og for både kvardagsspråket og det litterære språket.

Som før nemnt er det lite snakk om himmel og herlegdom blant vestlege teologar i dag. Likevel er førestillingar om himmel og livet etter døden til stades i vestleg folkeleg religion og kunst, gjerne i enkle salmar som «Hjemme i himlen skal ingen mer gråte», som også er mykje brukt i gravferder. Her ser vi enno ein metafor om livet etter døden, nemleg heime. Livet er borte, mens livet etter døden er heime. Med dette som utgangspunkt skal vi sjå nærmare på dei to salmane i denne studien.

\section{Om salmane}

Spørsmålet om korleis ein skal definere ein salme, har ei lang historie. Jan Ove Ulstein tek for seg nokre av desse (Ulstein, 2017, s. $187 \mathrm{ff}$.). Eit kjenneteikn er at ein salme må kunne syngjast av alle, og ikkje berre vere ein appell til oss sjølve, men noko vi kan syngje oss opp på. Salmen må ha både god poesi og ein tone som lyftar, og må dessutan vere ein forsamlingssong. Ulstein støttar seg på Anders Aschim, som siterer lyrikaren og salmediktaren Oskar Stein Bjørlykke: «Ein salme er eit dikt som kan syngjast i kyrkja. Ein god salme er eit dikt det er godt å syngje i kyrkja» (Aschim, 2016, s. 191). «Eg veit i himmerik ei borg» er ein slik salme. Salmen med ein folketone frå Hallingdal er med i Norsk salmebok frå 2013, der han er plassert under overskrifta «Det kristne håpet». Salmen er opphaveleg frå før år 160o, og er omsett frå den tyske salmen «Ich weiss ein ewiges Himmelreich» til nynorsk av Bernt Støylen i 1905. Salmen har også røter tilbake til den sentimentale tyske skillingsvisa «Es liegt ein Schloss in Österreich», ei vise som har spela ei viktig rolle i songtradisjonen. Hovudmetaforen i salmen, slottet eller borga, er nok henta frå denne folkelege tradisjonen, ein tradisjon som også Luther byggjer på i salmen «Vår Gud han er så fast ei borg». Hovudpersonen i salmen er ein fattig ferdamann, som også er 
ein vanleg metafor i den folkelege tradisjonen heilt opp til våre dagar. Det er grunn til å tru at salmen har henta noko av livskrafta si frå dette feltet (Olav Solberg, personleg kommunikasjon, e-post 1.12.17). Borger eller slott var elles noko som var kjent, og som mange hadde rett for auga i Tyskland i mellomalderen.

Også Bjørn Eidsvåg er representert i Norsk salmebok, med i alt fem salmar, men «Eg ser» er ikkje blant dei. Grunnen skal visst vere at songen er vanskeleg å syngje som fellessong, men likevel vil mange meine at «Eg ser» er ein salme, blant anna fordi den er mykje brukt i kyrkja, både i bryllaup og i gravferder. Songen var føreslegen til å vere med i den nye salmeboka, men kom ikkje med. Eidsvåg sjølv meinte at songen ikkje er ein salme, og røper etter Ulsteins meining kanskje eit strengare salmesyn enn salmebokkomiteen. Vidare seier Ulstein dette om kvaliteten på teksten til «Eg ser»:

Men det er ei uhyre sterk tekst, i munnen på ein medvandrar som viser seg å vere Jesus. Songen er så sterk at han har redda liv. Då eg arbeidde med ein større artikkel om Eidsvåg, fekk eg ei historie frå ein forfattarkollega. Songen hadde bokstaveleg tala redda livet hennar. Han løyste ut ein gråt som løyste, og ho tok ikkje livet sitt. (Ulstein, 2017, s. 194)

Som analysen nedanfor vil vise, handlar songen om ein medvandrar på livets veg, men om denne medvandraren er Jesus, er ei anna sak. Her kjem det truleg an på samanhengen teksten vert brukt i.

Ein nøkkel til å forstå teksten kan vere Eidsvåg sjølv, som medieaktør og populærartist er han «kjendis» og får dermed innpass både hos kyrkjegjengarar og «kyrkjeframande». Dette fører også til at teksten vert uvanleg open, noko eg skal kome inn på i analysen nedanfor.

Eidsvåg har sjølv fortalt til Stavanger Aftenblad at songen vart til på eit kvarters tid då han skulle halde ei preike mens han var prest på Lier psykiatriske sjukehus i 1983 (https://no.wikipedia.org/wiki/Eg_ser). Det var gjennombrotssongen hans og er også blitt omtalt som den viktigaste songen han har skrive. Songen er med i Tillegg til Norsk Salmebok frå 1997 og kan vel av den grunn også kallast ein salme.

Her er begge salmane ved sida av kvarandre: 


\begin{tabular}{|c|c|}
\hline Eg veit i himmerik ei borg & Eg ser \\
\hline 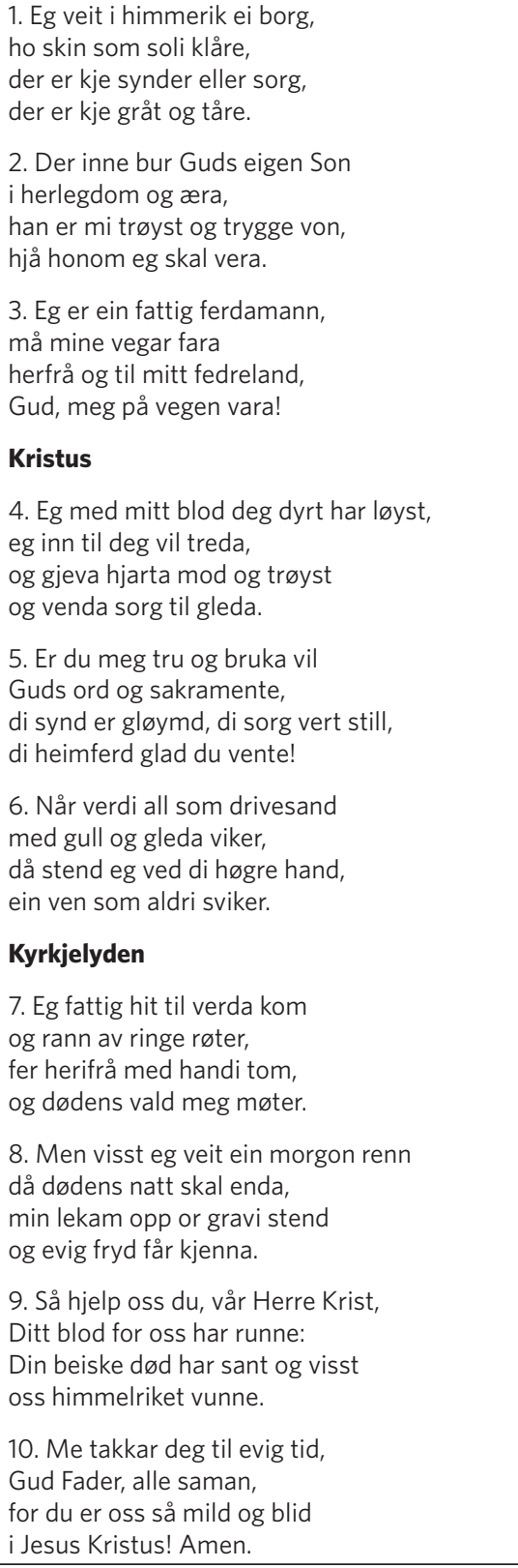 & $\begin{array}{l}\text { Eg ser at du e trøtt, } \\
\text { men eg kan ikkje gå alle skrittå for deg. } \\
\text { Du må gå de sjøl, } \\
\text { men eg vil gå de med deg, } \\
\text { eg vil gå de med deg. } \\
\text { Eg ser du har det vondt, } \\
\text { men eg kan ikkje grina alle tårene for deg. } \\
\text { Du må grina de sjøl, } \\
\text { men eg vil grina med deg, } \\
\text { eg vil grina med deg. } \\
\text { Eg ser du vil gi opp, } \\
\text { men eg kan ikkje leva livet for deg. } \\
\text { Du må leva det sjøl, } \\
\text { men eg vil leva med deg, } \\
\text { eg vil leva med deg. } \\
\text { Eg ser at du e redd, } \\
\text { men eg kan ikkje gå i døden for deg. } \\
\text { Du må smaka han sjøl, } \\
\text { men eg gjer død til liv for deg, } \\
\text { eg gjer død til liv for deg. } \\
\text { Eg har gjort død til liv for deg. }\end{array}$ \\
\hline Tysk, før 1600, omsett av Bernt Støylen, 1905 & Bjørn Eidsvåg, 1983 \\
\hline
\end{tabular}

1 Bjørn Eidsvågs «Eg ser»(C) Kirkelig kulturverksted. Henta frå: http://www.bjorneidsvag.no/ album/passe-gal/sanger/eg-ser. Brukt i samsvar med sitatretten. Songteksten er ikkje omfatta av CC-BY 4.o-lisensen til boka, og kan ikkje bli gitt att utan løyve frå den som har rettane. 
I diktanalysar er det vanleg å bruke termen strofe om større einingar og verslinje om ei enkelt linje i strofa. I denne analysen held eg meg til dei folkelege termane, som blir vers og linje. Som ein ser, har salmane ulik form. Salmen «Eg veit i himmerik ei borg» er forma som ein dialog mellom kyrkjelyden og Kristus. Kyrkjelyden syng om det vanskelege livet og om håpet i himmelen, mens Kristus syng om kva som ventar på den andre sida, og om kva kyrkjelyden må gjere for at håpet skal bli oppfylt. Salmen har heile ti vers, og det er fire linjer med enderim og fast rimmønster abab i alle versa. I gravferder er det mest vanleg å syngje berre fire vers, og det er som regel vers 1, 2, 3 og 8. Utvalet av nokre få vers er ifølgje Stig Wernø Holter «noe som naturligvis tilslører salmens indre struktur og mening» (Holter, 2011, s. 291). I analysen nedanfor vil eg derfor ta for meg alle versa i salmen.

«Eg ser» har fire vers, der dei tre første har seks linjer og det siste har åtte linjer. Her er det berre ein person som fører ordet, og som forklarer at det finst håp i det håplause for den som har kome så langt ned at han eller ho vil gje opp livet. Håpet ligg $i$ at det finst ein medvandrar som er villig til å vere der midt i det som er vanskeleg.

Det er elles verdt å merke seg at salmane er ulike med omsyn til språkleg form. «Eg veit i himmerik ei borg» er skriven på normert nynorsk, rett nok ikkje etter den siste rettskrivinga for skulen, der i-mål (soli) ikkje lenger er innanfor norma, mens «Eg ser» er skriven på dialekt frå Sauda-traktene, Rogaland, der Eidsvåg kjem frå. Det er ikkje svært vanleg med salmar på dialekt, og i nokre høve kan dialekt føre til at salmen får eit mindre høgtideleg preg, og at salmen framstår som nærmare livet og det menneskelege.

\section{Metaforar i salmane}

I denne delen vil eg ta for meg ein og ein salme, ved først å omtale metaforar om livet, deretter metaforar om døden og til sist metaforar om livet etter døden.

\section{Eg veit i himmerik ei borg}

Metaforar om livet finn vi i vers 3,6 og 7 . Først om metaforar i vers 3:

Eg er ein fattig ferdamann,

må mine vegar fara 
herfrå og til mitt fedreland,

Gud, meg på vegen vara!

Eg-personen framstiller seg sjølv som ein fattigferdamann på ein veg, eit kjent pilegrimsmotiv og ein kjend metafor frå mellomalderen, og målet for reisa er fedrelandet. Her ser vi med andre ord at livet er framstilt som ei farleg reise frå ein framand stad (livet på jorda) til ein heimstad eller eit fedreland (himmelen). Vegane er ikkje trygge, og Gud er framstilt som ein vaktmann eller bergingsmann på den farlege reisa.

Meir om livet kjem i vers 6:

Når verdi all som drivesand

med gull og gleda viker,

då stend eg ved di høgre hand,

ein ven som aldri sviker.

Verda eller menneskelivet utan Gud er likna med drivesand, som noko som ikkje er varig, og det er heller ikkje gull og gleder i verda. Då er det at følgjesveinen og medvandraren Kristus står ved menneskets høgre hand som ein ven utan svik, nærmast som ein klippe. At det er høgre handa og ikkje venstre, er ein referanse til fleire stader i Bibelen, der det blir vist til at Gud grip den truande si høgre hand, ut frå at den høgre sida er rekna for å vere den gjævaste (Holter, 2011, s. 291).

Dei siste metaforane om livet i denne salmen finn vi i vers 7 :

Eg fattig hit til verda kom

og rann av ringe røter,

fer herifrå med handi tom,

og dødens vald meg møter.

Her ser vi at fattigdommen igjen blir understreka, og at mennesket blir framstilt som eit tre eller ein plante med røter, som også er svake eller fattigslege (ringe røter). Det fattigslege blir igjen understreka av at eg-personen reiser med handi tom. I siste linje møter eg-personen døden.

«Eg veit i himmerik ei borg» omtaler døden i vers sju og ni. Dei to siste linjene i vers sju er slik:

fer herifrå med handi tom

og dødens vald meg møter. 
Gjennom uttrykket fer herifrå blir også døden metaforisert som ei reise, og gjennom uttrykket dødens vald, som er ei personifisering, blir døden framstilt som ein valdeleg person. Også i vers ni møter vi døden, gjennom at Kristi blod «har runne» og gjennom uttrykket din beiske død. Vår motstand mot døden blir her framstilt med hjelp av metaforar knytte til smak, eller som ei gift. Når noko smakar beiskt, vil vi gjerne spytte det ut og ikkje ta imot det eller svelgje det.

Vidare teiknar salmen eit bilete av livet etter døden gjennom dei to første versa:

Eg veit i himmerik ei borg,

ho skin som soli klåre,

der er kje synder eller sorg,

der er kje gråt og tåre.

Der inne bur Guds eigen Son

i herlegdom og æra,

han er mi trøyst og trygge von,

hjå honom eg skal vera.

Her stig det fram eit bilete av ei borg, eit gullslott, ein opphøgd og opplyst stad som er bustaden til Guds eigen son, eit trygt og godt haldepunkt for eg-et i salmen. I det verdslege, tyske førelegget til salmen vart metaforen slott brukt. Borg, som er brukt i den norske salmen, er innført av Støylen og ifølgje Holter truleg inspirert av Salme 46. Holter peikar også på at resten av strofa refererer til visjonen om det nye Jerusalem i Openberringa 21 (Holter, 2011, s. 291). Det er til den skinande borga den fattige ferdamannen har tenkt seg etter døden. Men han må gjennom døden før dette kan skje, i det åttande og niande verset:

Men visst eg veit ein morgon renn

då dødens natt skal enda,

min lekam opp or gravi stend

og evig fryd får kjenna.

Så hjelp oss du, vår Herre Krist,

Ditt blod for oss har runne:

Din beiske død har sant og visst

oss himmelriket vunne. 
Her kjem metaforane på rekkje og rad: Tida er framstilt som ei elv, der morgonen renn fram. Livet er morgon, og døden er natt. Og etter døden kjem oppstoda, der lekamen både bokstaveleg og metaforisk tala reiser seg frå grava til ein tilstand av evig liv og evig fryd. Vidare er kampen med døden vunnen gjennom Kristi død, og dermed er det himmelen som er målet og meininga med livet. Det siste verset i salmen er då også formulert som ein takk for denne store gåva. Slik sett står denne salmen for eit klassisk håp om evig liv, ved at han framstiller døden som inngang til eit nytt liv.

\section{Eg ser}

Den første metaforen vi møter i Eidsvågs tekst, er knytt til verbet å sjå. «Eg ser» er gjentatt mange gongar gjennom teksten, gjennom at eg-personen ser at den andre er trøytt, har det vondt, vil gråte og vil gje opp å leve. Her blir det etablert eit konvensjonelt metaforisk band mellom å sjå og å forstå, eit samband som er så kvardagsleg og vanleg at det er nesten umerkeleg. Også i Eidsvågs tekst er livet ei reise, der det er snakk om å gå til fots. Og det finst ein medvandrar, med evne til å sjå og forstå. Livet er framstilt som ei lang og tung reise, som ein kamp som medfører mange skritt og tårer, men medvandraren er ikkje framstilt som ei klippe, slik Kristus står fram i den første salmen. Medvandraren kan heller ikkje love så mykje som Kristus kan, men han lovar å gå saman og gråte saman med den lidande. I tredje vers kjem den dramatiske metaforen: «Eg ser du vil gje opp». Når livet er ein kamp, vil det å gje opp bety det same som å gje opp kampen, å resignere, eller også ta sitt eige liv. Det motsette av gje opp er å halde fram med å kjempe og leve livet sitt. Også her må medvandraren vedgå at han ikkje kan leve livet for den andre: «eg kan ikkje leva livet for deg, du må leva det sjølv, men eg vil leva med deg.» I denne strofa ligg døden og lurer som eit val og som eit alternativ til å leve, men døden viser seg ikkje tydeleg før i det fjerde og siste verset.

Metaforar knytte til reise og smak finn vi også i «Eg ser» i det siste verset:

Eg ser at du e redd,

men eg kan ikkje gå i døden for deg.

Du må smaka han sjøl, 
Her er det uttrykket gå $i$ døden og smaka han som står for dei same kjeldeområda som i den første salmen, men her er ikkje sjølve smakstypen omtalt. Å smake her står for å ta ein liten bit av, og at det då er slik at døden høyrer med til livet. Døden blir då ikkje berre slutten av livet, men også ein del av livet som alltid er med oss, og som vi må forsone oss med.

Ved første gjennomlesing av Eidsvågs tekst tenkte eg at dette er ein tekst som først og fremst handlar om livet og litt om døden, men at det ikkje er spor av noko liv etter døden i salmen. Men etter kvart har eg tenkt meg fram til at dei fire siste linjene kan handle om livet etter døden:

men eg gjer død til liv for deg,

eg gjer død til liv for deg.

Eg har gjort død til liv for deg.

Om ein forstår eg-personen som Kristus, vil den tradisjonelt kristne forståinga av Kristi død og oppstode kunne stå for det å gjere død til liv. Men ein kan også tenkje seg at død her skal forståast metaforisk og ikkje bokstaveleg. Ein som er full av sorg, vil kunne kjenne seg som å vere død, sjølv om han eller ho er i live. Då opnar teksten for ei forståing av at eg-personen og medvandraren kan vere eit medmenneske til hjelp og støtte i bratte bakkar på livsvegen. Men samtidig vil den siste setninga: «Eg har gjort liv til død for deg» igjen styre tankane i retning av Jesu død på korset og ei kristen tolking. Men her vil som sagt samanhengen salmen blir brukt i, kunne avgjere korleis han blir forstått.

\section{Oppsummering av funn}

Innleiingsvis presenterte eg tre spørsmål om kva metaforar som er brukte om livet, døden og livet etter døden i dei to salmane, kva førestillingar og tenkjemåtar metaforane er uttrykk for, og om det er skilnad på metaforbruk og tenkjemåtar i dei to salmane.

For det første er det mange konvensjonelle metaforar i begge salmane, mens det er meir litterære og tydelege metaforar, som til dømes borga i himmelriket, i den første salmen. Dei konvensjonelle metaforane i begge salmane framstiller livet som ei hard og slitsam reise, og som ein strid 
eller kamp. Begge salmane har metaforar om ein følgjesvein på reisa, Kristus i den første salmen og kanskje Kristus eller eit medmenneske i den andre. Som eg var inne på tidlegare, hevdar Jan Ove Ulstein at medvandraren er Kristus. Andre lesarar har fortalt meg at dei har sett for seg at det er eit medmenneske som snakkar, og at salmen ikkje har noko spesifikt kristent innhald for dei. «Eg ser» er med andre ord ein open tekst (Eco, 1984), ein tekst som inviterer til fleire tolkingar, mens ein lukka tekst er ein som inviterer til ei bestemt tolking. I ein open tekst er det samanhengen som avgjer korleis medvandraren og metaforane blir oppfatta. I den første salmen, som er ein opplagt kristen tekst, er det også sagt rett ut at medvandraren er Kristus, ein følgjesvein som aldri svik. Den andre salmen, derimot, kan tolkast både kristent og humanistisk, alt etter kva kontekst salmen blir brukt i. Dermed vil det også vere ulik forståing av kva døden er i dei to salmane.

I begge salmane er døden framstilt som noko ein smakar på, og som smakar vondt. Men i den første salmen er døden samtidig ei trøyst og ein inngang til ei ny reise mot evig liv og evig fryd og fest i ei sterkt opplyst borg, og lyset spelar ei viktig rolle. Dette kan ha samanheng med at det er ein eldre tekst, frå før 1600. Som vi såg i Olav Solbergs kapittel i denne boka, har Umberto Eco (1986) funne at mellomalderestetikken var prega av det skinande lyset, som representerer både himmelsk og jordisk venleik.

I den andre salmen, derimot, er både liv og død prega av mørke, og i tillegg kan både liv og død oppfattast som metaforar for tilstandar, som å vere frisk eller deprimert, særleg om konteksten er ikkje-kyrkjeleg.

Ingen av salmane oppfattar døden som søvn eller kvile, og det er heller ikkje metaforar knytte til helvete og fortaping i dei. Dette er interessant sett $\mathrm{i}$ lys av at det er så stor skilnad i alder mellom tekstane. Ein skulle kanskje tenkt at helvete ville vere til stades i ein tekst som er så nær mellomalderen. I den grad denne salmen er del av folkeleg kristendom, kan Repstad ha rett $i$ at folkeleg kristendom kan ha vore mjukare enn kristendommen hos helvetesorienterte omvendingspredikantar.

Når det gjeld spørsmålet om metaforane er teosentriske eller antroposentriske, om målet er å møte Gud eller å møte sine kjære etter døden (sjå side 37), er den første salmen opplagt teosentrisk, mens den andre salmen 
ikkje tek opp dette spørsmålet direkte. I den grad himmelen finst, er han flytta ned på jorda gjennom samtalar mellom den som lid, og den som ser og forstår. På dette området plasserer «Eg ser» seg i det meir terapeutiske feltet saman med danske prestar som ikkje kan snakke om himmel, men er medtruande i samtalar der den andre trur på ein himmel.

I den grad Gud er til stades i salmane, korleis er så gudsbiletet med omsyn til kjønn? I den første salmen er det opplagt at Gud er mann, i og med at det er Kristus, Guds son, som snakkar. Dette er då også det vanlege i både eldre og nyare salmebøker (Stenvag, 2013). I den andre salmen kan Gud vere ein mann, men også eit medmenneske, som då vil kunne vere både kvinne og mann.

Språket vårt om Gud, liv og død er nedarva, og vi er delvis fanga i dei metaforane vi har arva gjennom tidene. Særleg er dette relevant for religiøs språkbruk og salmar, som oftast har Bibelen som grunnlag. Å endre patriarkalsk orienterte metaforar vil vere å likne med eit sisyfosarbeid, sjølv om det finst måtar å endre verda på, også språkleg:

Når feministpresten Gyrid Gunnes skriv eller syng salmar, erstattar ho alltid «fader» med «moder». «Ideelt sett burde man bruke begge pronomenene, men i en tradisjon hvor de fleste bruker «han» er det viktig å si «hun». Enn så lenge, sier feministpresten Gyrid Gunnes.» (Klassekampen 23. februar 2013, s. 10.)

Mens vi ventar på at metaforane om Gud skal endre seg og gje oss bilete av både mann og kvinne, kan vi halde fast på metaforane om ein forståande følgjesvein som seier «Eg ser», og ei klar og skinande borg som ventar på oss $\mathrm{i}$ «himmerik».

\section{Referansar}

Eco, Umberto (1984). The Role of the Reader: Explorations in the Semiotics of Texts. Bloomington: Indiana University Press.

Holter, Stig Wernø (2011). Eg veit i himmerik ei borg. I Stig Wernø Holter, Ragnar Grøm \& Vigdis Berland Øystese (Red.), Nytt norsk salmeleksikon. B1:A-G.

Trondheim: Tapir Akademisk Forlag.

Johannesen, Aud, \& Askeland, Norunn (2018). Metaforer om sykdom og død - en litteraturoversikt. I Aud Johannesen, Norunn Askeland, Iben Brinch Jørgensen \& 
Jorun Ulvestad (Red.), Døden i livet. Oslo: Cappelen Damm Akademisk. https:// doi.org/10.23865/noasp.40.

Lakoff, George, \& Johnson, Mark (1980). Metaphors We Live By. Chicago: University of Chicago Press.

Lakoff, George, \& Turner, Mark (1989). More Than Cool Reason. A Field Guide to Poetic Metaphor. Chicago: University of Chicago Press.

Leer-Salvesen, Bjarte (2011). Levende håp: En praktisk-teologisk analyse av 51 presters forkynnelse ved gravferd. Avhandling for graden philosophiae doctor ( $\mathrm{PhD})$, Fakultet for humaniora og pedagogikk, Institutt for religion, filosofi og historie, Universitetet i Agder.

Repstad, Pål (2015). Fortapelse og feelgood. Endringer i synet på helvete og fortapelse. Teologisk tidsskrift, nr. 1, 2015, 65-85.

Solberg, Olav (2018). På tvers av døden. Grensa mellom levande og døde i kulturhistorisk lys. I Aud Johannesen, Norunn Askeland, Iben Brinch Jørgensen \& Jorun Ulvestad (Red.), Døden i livet. Oslo: Cappelen Damm Akademisk. https://doi.org/10.23865/noasp.40.

Stenvaag, Hanne (2013). Salmebok gjør Gud til mann. Verdidebatt.no. Lesedato 19.03.17.

Stimpel, Birgitte Bjørn, \& Raakjær, Ole (2016). Himlen, der forsvandt. Omsorg, nr. 1, 2016, 20-25.

Turner, Mark (1996). The Literary Mind. The Origins of Thought and Language. Oxford: Oxford University Press, US.

Turner, Mark (2006). The Artful Mind. Cognitive Science and the Riddle of Human Creativity. Oxford: Oxford University Press.

Ulstein, Jan Ove (2017). Salmar på dialekt? - Litt om lokalisering av trusuttrykk. Kirke og kultur, nr 2, 2017, 187-199. 


\title{
KAPITTEL 3
}

\section{På tvers av døden. Grensa mellom levande og døde i kulturhistorisk lys}

\author{
Olav Solberg \\ Universitetet i Søraust-Noreg
}

\begin{abstract}
Summary: In the old preindustrial society people felt that they lived surrounded by supernatural powers. Even the dead continued to live a life of their own in the grave, and there was a continued contact between the dead and the living. Folk tales, legends and ballads tell stories of how the dead could return to society for a short time, and vice versa how the living might gain access to the afterlife. In my article I discuss some texts from oral tradition in order to shed light on the relationship between the living and the dead in the old society. There is no doubt that revenants and the land of the dead seemed frightening to most people, but still the contact between the two opposite worlds created an alternative and in some respects fascinating picture of society. This alternative picture might function as a useful corrective to people in their ordinary lives.
\end{abstract}

Keywords: afterlife, ghosts, paradise, two worlds, vision

I det gamle og førmoderne samfunnet levde folk i eit system av makter. Det var for det første dei himmelske maktene - englane og helgenane med jomfru Maria i spissen. Dei himmelske maktene var aldri langt unna og kunne påkallast til hjelp og støtte. Om helgenane offisielt vart forviste ved reformasjonen, levde dei vidare i folketrua. Så var det dei naturmytiske maktene som levde i naturen, i haug og berg, i vatn, elvar og sjøar. Tilhøvet til dei underjordiske var ambivalent. Det galdt å stå på god fot med dei og la dei vera i fred.

Endeleg var det dei døde. Dei døde var nok borte, men levde likevel vidare - ikkje berre i minnet, men i gravene på kyrkjegarden, i skirselden, i himmelen. I det følgjande skal vi sjå korleis grensa mellom liv og død har vore oppfatta. Litterære og historiske kjelder, og ikkje minst folketradisjonen, er tydelege på at denne grensa ikkje har vore noko uoverstigeleg

Sitering av denne artikkelen: Solberg, O. (2018). På tvers av døden: Grensa mellom levande og døde i kulturhistorisk lys. I A. Johannessen, N. Askeland, I. B. Jørgensen \& J. Ulvestad (Red.), Døden i livet (Kap. 3, s. 51-67). Oslo: Cappelen Damm Akademisk. https://doi.org/10.23865/noasp.40.ch3

Lisens: CC BY-NC 4.0 
skilje. Det har vore mogleg for levande å krysse grensa til dødsriket, og koma frå det med livet, dvs. koma attende til menneskesamfunnet. Og ikkje minst finst det mange vitnemål om at døde menneske kan koma tilbake til livet på jorda, for ei kort tid.

Kva har dei døde betydd for dei levande? På kva måte kunne dei døde gjera seg gjeldande i livet? I kva grad kunne dei døde formidle innsikt om livet etter døden og altså fungere som vegvisarar $\mathrm{i}$ «den andre heimen»? Metodisk er tilnærminga ein kombinasjon av nykritisk nærlesing og nyhistorisme, dvs. at tekstane skal analyserast i lys av det samfunnet der dei vart til. Det dreiar seg om korte tekstar, der det litterære relativt tydeleg refererer til det verkelege. Alle historiske problemstillingar gjeld eigentleg vår eiga tid. Dette betyr at spørsmåla eg drøfter, har meining for moderne menneske.

I det følgjande drøfter eg nokre tradisjonstekstar, eventyr, balladar, segner - dvs. tekstar som tilhøyrer dei «store» folkediktingssjangrane. Språk, stil og forteljeteknikk er ulik, men uansett formidlar tradisjonstekstar alltid ei oppfatning av menneske og samfunn. Det gjeld også eventyret, det nærmaste tradisjonsdikting kjem fantasy. Som kjent gir eventyret seg sjeldan ut for å vera sant, men det er berre på overflata. Det «sanne» ligg i tematikk, menneskeskildring, samfunnsoppfatning. Balladen er den formelt sett mest bundne av dei tre sjangrane, lett å kjenne igjen på strofer og omkvede. Balladen og andre tradisjonsviser framstiller ei mengd sentrale emne, alvorlege og humoristiske. Segna er meir jordnær og forteljeteknikken relativt enkel, jamvel om vi må vera klar over at Asbjørnsens huldreeventyr-segner er bygde ut, forbetra og gjort meir litterære. I den munnlege tradisjonen var det ei spesialkunst for dei få å framføre lange balladeforteljingar eller å fortelja underfulle eventyr med episk kraft. Segnforteljing var derimot noko dei fleste kunne klare. Men eventyr, balladar og segner levde i same miljø og har derfor påverka kvarandre.

\section{Døde går igjen}

\section{Gjengangarar i kyrkja}

At døde kan koma tilbake til menneskeverda som gjengangarar, spøkelse, gjenferd eller draugar, er ei eldgammal førestilling. Ikkje eingong kyrkja 
er nokon trygg tilhaldsstad i møte med gjengangarar, går det fram av Peter Chr. Asbjørnsens huldreeventyr «En gammeldags juleaften». Denne klassiske grøssaren stod første gongen på trykk i avisa Den Constitutionelle i 1843, og vart seinare utgjeven (1845) med nokre mindre endringar i Norske Huldreeventyr og Folkesagn. Første Samling (Solberg, 2008, s. 55-60, 178-179). Asbjørnsens huldreeventyr er oftast sette saman av rammeforteljingar kring ei rekke korte historier (segner). Desse historiene har som regel eit felles tema, og $\mathrm{i}$ «En gammeldags juleaften» er temaet julefeiring $\mathrm{i}$ gamle dagar, i Asbjørnsens barndom og tidlegare. Hovudhistoria er ei eldgammal segn, den såkalla «Dauinggudstenesta», som vart skriftfest første gongen av krønikeskrivaren Gregor av Tours, kring 600 e.Kr. Seinare har segna blitt skriven ned i mange land, også i Noreg. Den eldste norske varianten vart oppteikna i 1786 av seljordspresten Hans Jacob Wille.

Kort fortalt handlar «Dauinggudstenesta» slik Asbjørnsen fortel segna, om ei enke som skal til ottemesse tidleg juledagsmorgonen. Så har klokka hennar stansa, og ho kjem for tidleg i kyrkja. Der er ikkje alt som det skal, ho synest dei andre i benken ser så underleg bleike ut, og presten er heilt ukjend. Dessutan er det så stilt at ho kan høyre ei nål falle, og ingen hostar eller harkar slik folk gjerne gjer i kyrkja. Då er det ei kone bøyer seg mot henne og kviskrar at ho skal kaste kåpa laust om seg og gå, for det er dei døde som held gudsteneste:

[...] Da hun hørte stemmen og så på konen, kjente hun henne; det var nabokonen hennes, som var død for mange år siden, og da hun nu så seg om i kirken, husket hun godt at hun hadde sett både presten og mange av menigheten og at de var døde for lange tider siden. Det isnet i henne, så redd ble hun. Hun kastet kåpen løst om seg, som konen hadde sagt, og gikk sin vei; men da syntes hun de vendte seg og grep efter henne alle sammen, og benene skalv under henne, så hun nær hadde segnet ned på kirkegulvet. (Asbjørnsen \& Moe, 1978 1, s. 28)

Heldigvis går det bra med enka, og det kan ho takke den døde grannekona for. Dei døde lèt henne sleppe unna og nøyer seg med å rive kåpa i tusen stykke.

I Willes variant av segna møter vi også ei kone som kjem for tidleg til ottemesse, men med henne går det ille. Det hjelper ikkje at ho blir åtvara 
av ei død syster: «Vi er Drouger, nu faar du løbe, thi see din Bedstefader, hvor vred han er fordi du ikke har kaldet ham op (reist ham up), han vil dræbe dig» (Hodne, 1992, s. 128). Systera ber henne springe for livet og kaste av seg det eine klesplagget etter det andre, først trøya, deretter beltet og så forkledet. Kona gjer slik den døde systera seier, men har så lang veg heim at den rasande bestefaren får tak i henne. Han «greb [...] hende og klemte hende mellem Hænderne, saa hun døde 2 Dage derefter» (Hodne, 1992, s. 128).

Den grunnleggjande førestillinga $\mathrm{i}$ «Dauinggudstenesta» er at den normalt uoverstigelege grensa mellom levande og døde kan kryssast. Til visse tider, ved visse høve og på visse stader kan dei døde koma attende. Då må dei ikkje forstyrrast, slik begge dei to konene ufrivillig kjem til å gjera. Av Willes segn går det fram at den døde bestefarens aggressive framferd har ein grunn. Kona har ikkje kalla han opp. Segna fungerer altså som ei påminning til dei levande om å følgje slektssamfunnets normer. At ein bestefar skulle hate barnebarnet sitt så intenst at han vil ta livet av vedkomande, verkar sjølvsagt ikkje logisk. Men gamle segner er ikkje alltid logiske ut frå moderne tankegang, det logiske og viktige er at dei døde kan vera livsfarlege i visse situasjonar.

Natta er dei dødes tid. Gjengangarar viser seg gjerne nattetider, men når hanen gjel, må dei skunde seg attende til gravene. Julenatta opnar alle graver seg, og då held dei døde si eiga gudsteneste i kyrkja. Ein kan sjå lys i kyrkja og høyre song:

I en Värmlandssocken såg kyrkvaktaren en gång att ljusen var tända i kyrkan kl. 12 på julnatten. Han skyndade sig dit och fann till sin förskräckelse att det i bänkarna sat fullt med benrangel, klädda i sina liksvepningar, och alla sjöng:

Med lätta fötter gånge vi,

Med kalla tungor sjunga vi.

Hur långt det är till domedag, det fråga vi.

(Hagberg, 2016, s. 662)

Det er ingen tvil om at folk flest i det gamle samfunnet trudde at gjengangarar fanst. Det galdt å ta sine forholdsreglar slik at ein kunne sleppe å møte dei. Like sikkert er det at trusførestillingane fungerte som grunnlag 
for dikting og fantasifull utbrodering. Gjengangartematikken var som skapt for underhaldning, tidtrøyte og spenning - frygdefull grøss og gru. Dette kjem klart til uttrykk i «Dauinggudstenesta» og endå tydelegare i visene og forteljingane om den døde festarmannen.

\section{Den døde festarmannen}

Gjengangarane har alltid eit viktig ærend når dei kjem attende til jordelivet. Fleire gamle viser og prosaforteljingar kretsar rundt eitt spesielt motiv - ein død mann vender attende frå grava for å hente kjærasten sin. I «Festarmann i grava», ein av dei gamle mellomalderballadane, er dette motivet sentralt. Her blir det fortalt at festarmannen døyr like før bryllaupet, og kjærasten sørgjer så sårt at den døde ikkje får fred i grava. Til sist tek festarmannen kista på ryggen og går til jomfruburet der kjærasten ventar. Han bankar på døra, men ho tør ikkje opne, og ber han nemne Jesu namn. Det gjer festarmannen, og ho slepper han inn. Men han må attende til grava før hanen gjel. Det heile endar på kyrkjegarden. Der blir festarmannen borte i den svarte molda, mens kjærasten står sorgtyngd att på grava. Kort tid etter er ho sjølv død.

Balladar og andre viser i stil med «Festarmann i grava» har funnest $i$ mange europeiske land. Desse interesserte den tyske lyrikaren Gottfried August Bürger seg for, og i 1773 skreiv han kunstballaden «Leonore». Diktet vart ein formidabel suksess, «en av de store inspirasjoner i romantikkens balladediktning» (Midbøe, 1946, s. 41-42). Bürger vart med denne balladen ein av føregangsmennene i skrekkromantikken og den såkalla gotiske litteraturen. «Leonore» vart omsett til mange språk og har inspirert andre diktarar, komponistar og målarar.

I Bürgers ballade er handlinga utbygd og dramatisert. Strofene er heller ikkje vanlege balladestrofer, og framstillinga minner ikkje mykje om den vanlegvis objektive stilen i tradisjonsballaden. I Bürgers tekst blir det makabre emnet underbygd av enorm aktivitet og ikkje minst av lydar rop, skrik og huing. Vinden susar, klokker klemtar, det gnistrar under hestehoven. Handlinga går føre seg like etter sjuårskrigen. Wilhelm, som er kjærast med Leonore, har ikkje kome attende, og ho er engsteleg for kva som kan ha skjedd. Så ved midnatt bankar ein framand på døra, og denne 
framande liknar til forveksling på Wilhelm. Han bed Leonore setja seg på den svarte gangaren og følgje med til ektesenga. Glad stig Leonore opp, og dei rir av stad i eit forrykande tempo, i månelys og i eit spøkelsesaktig landskap. Leonore blir redd og spør kvifor dei rir så fort, men ryttaren svarar at dei døde alltid rir på denne måten. Ved soloppgang når dei fram til kyrkjegarden, og då viser seg det seg at ryttaren ikkje er Wilhelm, men Døden sjølv, i form av eit beinrangel med sigd og timeglas. Ektesenga er grava, der den døde Wilhelm ligg. Jorda brest under Leonore, og ånder dansar kvilelaust rundt henne i ring:

Ha sieh! Ha sieh! im Augenblick,

Huhu! ein grässlich Wunder!

Des Reiters Koller [rustning], Stück für Stück,

Fiel ab, wie mürber Zunder [knusk].

Zum Schädel [hovudskalle], ohne Zopf und Schopf [hår],

Zum nackten [bar] Schädel ward sein Kopf,

Sein Körper zum Gerippe [beinrangel],

Mit Stundenglas [timeglas] und Hippe [sigd].

(Midbøe, 1946, s. 46)

Bürgers ballade vart ikkje berre omsett til andre språk, den inspirerte også til nye viser med liknande emne. Innhaldet vart dessutan forma ut i andre sjangrar. I ei segn frå Nordland blir det fortalt om ei jente som heiter Karen. Festarmannen døyr, og ho sørgjer tidleg og seint. Ein kveld bankar den døde festarmannen på og spør om ho vil følgje med han. Ja, det vil ho, og dei set seg opp på den svarte hesten hans. I månelyset rir dei til kyrkjegarden. Der bind festarmannen hesten i ein gravkross og gjev seg til å kaste opp grava si. Men då angrar jenta, ho spring inn i likhuset og låser døra etter seg. Der får ho uventa selskap av eit lik som ventar på å bli gravlagt. Kort tid etter kjem festarmannen og ber henne opne døra, men jenta har ikkje lenger lyst til å døy. Festarmannen ropar då til liket i likhuset:

«Du bror, som inde er, luk op», men fik til svar: «Aanei, jeg kan ikke staa op, for de har vendt hovedet mit til døren.» Saa maatte pigen sitte i lighuset, til det blev morgen; men siden sørgede hun ikke paa en saa ufornuftig vis over sin fæstemand. (Nicolaissen, 1887, s. 26-27) 
Av fleire detaljar kan vi sjå at Bürgers ballade ligg til grunn for segna. I begge tekstar rir festarmannen på ein svart hest, og festarmannen i segna stiller eit spørsmål som refererer til dei skrekkromantiske skildringane i balladen: «Paa veien sagde han til hende: «Jeg rider sagte, og maanen skinner saa silde, Karenmor, er du ræd?» «Nei», svarede pigen, og mere blev der ikke talt» (Nicolaissen, 1887, s. 26-27). Segna er tilpassa den nordnorske kvardagen, med likhus og ein vanleg kyrkjegard, der festarmannen sjølv må spa opp grava si. Bodskapen er jordnær, ein skal ikkje sørgje over dei døde på ufornuftig vis, slik at ein tek skade av det. Segna blir dessutan innleidd med eit allment råd om korleis ein skal hindre døde i å gå igjen: «Det er paa flere steder skik at lægge staal og en gudelig bog hos den døde, som ligger paa ligstraa, for at han ikke skal gaa igjen, og at vende hans hoved mod døren» (Nicolaissen, 1887, s. 26). Det siste tiltaket skal hindre at den døde ser kvar utgangen på rommet er, noko som kunne setja han på tanken om å gå sin veg.

\section{$\AA ̊$ rette opp synd og skam}

Ein viktig grunn til at døde vender tilbake som gjengangarar, er at dei har gjort noko gale i levande live, som dei ikkje har fått retta opp. Deildegasten er ein gjengangar av denne typen. Han har flytt grensesteinar eller deilder til sin eigen fordel. I det gamle bondesamfunnet der jord var avgjerande for livsgrunnlaget, vart slikt sett svært alvorleg på. Den som vart teken i å stela jord på denne måten, vart dømd til eit liv som fredlaus (Kvideland \& Sehmsdorf, 1988, s. 118-121). Dessutan måtte han rekne med streng straff etter døden. I «Draumkvedet» møter Olav Åsteson syndesjeler av fleire kategoriar, deriblant ein mann som har flytt deilder. Som straff må han gå med blodige eller blødande hender, heiter det. I tradisjonen om deildegasten blir det elles fortalt at han strevar med ein diger grensestein som han prøver å løfte opp og få på plass. Men dette greier han aldri, og må slite med steinen til evig tid. Det einaste som kan gje han fred i grava, er om nokon vågar å spørje han kvar steinen opphavleg stod, og få sett den på rett stad (Espeland, 2002, s. 103-105).

Når nokon døydde i det gamle samfunnet, knytte det seg stor interesse til korleis det ville gå med den døde. Det avgjerande spørsmålet var om vedkomande kunne ha von om å koma på rette staden. Var kista med 
den døde lett å dra for hesten, kunne ein rekne med at sjela var på veg til himmelen. Kvite fuglar i lufta og tretoppane var også eit godt varsel, mens svarte fuglar spådde ille (Kvideland \& Sehmsdorf, 1988, s. 87-89). Både etter teologien og folketrua stod det klart at det berre var enkelte heilage menneske som kom direkte til himmelen, alle andre måtte finne seg i eit opphald i skirselden.

I balladen «Den vonde stemora» er det i alle høve slik at ei død mor kjem direkte til himmelen. På dødsleiet har ho rådd mannen sin til å finne seg ei ny kone med godt sinnelag, og ikkje bry seg om vakker utsjånad og fine klede. Men når kona vel er komen i jorda, gløymer han dei gode råda. Den nye kona blir stemor for barna hans, og ho blir ei vond stemor. Barna græt og klagar seg, og dette høyrer den døde mora i himmelen. Vårherre gjev den døde mora løyve til å vende attende til livet på jorda. Men ho må vera tilbake før hanen gjel to gonger:

Signelill går for sin herre å stå:

«Må eg meg på jorderik gå?»

«Du må deg på jorderik gå, når du kjem att til hanen gjel to».

(Solberg, 2003, s. 53)

Ei mørk natt kjem så den døde og talar den vonde stemora til rette. Ho på si side skjønar alvoret og blir heretter ei god stemor. Gjengangarar held som regel til i gravene på kyrkjegarden, eller dei kan vera gravlagde andre stader. Den døde mora har alt kome til himmelen, og høyrer eigentleg ikkje til gjengangar-kategorien. Likevel illustrerer «Den vonde stemora» at grensa mellom levande og døde kan kryssast når noko avgjerande står på spel.

\section{På besøk i den andre heimen}

\section{Vener i liv og død}

Asbjørnsen og Moes eventyr «Smeden som de ikke torde slippe inn i helvete» formidlar på ein humoristisk måte ei førestilling om at det kan vera vanskeleg å få innpass både i himmel og helvete. Hovudpersonen er ein smed som har gjort ein fordelaktig kontrakt med djevelen og hatt god 
nytte av det i mange år, og han prøver først å få tak over hovudet i helvete. Men djevelen har lært smeden å kjenne som ein vriompeis, og vil ikkje gje han husrom. Derfor syter han for å låse porten med ni låsar og ein ekstra hengelås på toppen. Smeden må freiste lykka i himmelen, men dit kjem han kanskje for seint, for St. Peter er i ferd med å slå porten igjen bak ein mager skreddarsvein.

Ifølgje dette eventyret går vegen både til himmel og helvete via ein port. Førestillinga om himmelporten er etter alt å døme henta frå Johannes' åpenbaring kap. 21, der det blir fortalt om ein ny himmel og ei ny jord og dei tolv perleportane til det nye Jerusalem. Men korleis såg det ut bak perleporten? Korleis var livet på denne vidunderlege staden? Om dette spørsmålet handlar eit anna Asbjørnsen og Moe-eventyr, «Venner i liv og død». Dette eventyret har vore relativt vanleg her i landet. Det finst dessutan i mange andre land og skal visstnok kunne sporast tilbake til ein latinsk tekst frå 1200-talet (Hodne, 1998, s. 182-187).

Eventyret handlar om to unge menn som er så gode vener at dei gjer ein avtale om ikkje å skiljast, verken i liv eller død:

Den ene ble ikke gammel før han døde, og en stund etter fridde den andre til en gårdmannsjente, fikk henne til kjæreste og skulle gifte seg. Da de ba til bryllups, gikk brudgommen selv til kirkegården, der vennen lå, banket på graven og ropte på ham. (Asbjørnsen \& Moe, 1978 2, s. 210)

Langt om lenge dukkar den døde opp og blir med i bryllaupet, slik dei har avtala tidlegare. Når den døde venen seinare skal attende til kyrkjegarden, følgjer brudgomen med. Han er nyfiken på korleis det ser ut i dødsriket, og det endar med at han blir med ned i grava. Det ber av stad gjennom mørker, kjerr og myrlende til dei kjem til ein diger port. Porten opnar seg, og snart kjem dei til ein buskap som beiter på gildt og godt gras, men likevel ser kyrne magre og elendige ut. Brudgomen undrar seg over dette, og den døde svarar at det heile er ei likning. Dei magre kyrne er eit bilete på griske menneske som aldri er fornøgde, same kor mykje dei skaffar seg av gods og gull. Dei to dreg vidare og kjem snart til ein annan buskap. Desse kyrne er blanke og feite i skinnet, trass i at dei beiter på knausar og skarvefjell. Dette er ei likning på menneske som var fornøgde med lite her på jorda, forklarer den døde venen. 
Ved eit strålande vakkert vatn forlèt den døde venen brudgomen ei stund, og brudgomen sovnar. Når han vaknar, er han heilt overgrodd av mose og buskar. Den døde venen følgjer han attende til grava, og brudgomen legg straks vegen til bryllaupsgarden. Men når han kjem dit han meiner bryllaupsgarden skulle vera, «kunne han ikke kjenne seg igjen. Han så seg om på alle kanter, og han spurte alle han møtte; men han fikk hverken hørt eller spurt brud eller slekt eller foreldre» (Asbjørnsen \& Moe, 1978 2, s. 213). Til sist går han til presten, og presten finn ut av kyrkjebøkene at bryllaupet stod for hundrevis av år sidan. Så lenge har brudgomen vore borte, målt i jordisk tid. Eventyret endar med at brudgomen - nå ein eldgamal mann - klatrar opp i den store eika som står i prestegarden, ramlar ned og slår seg i hel.

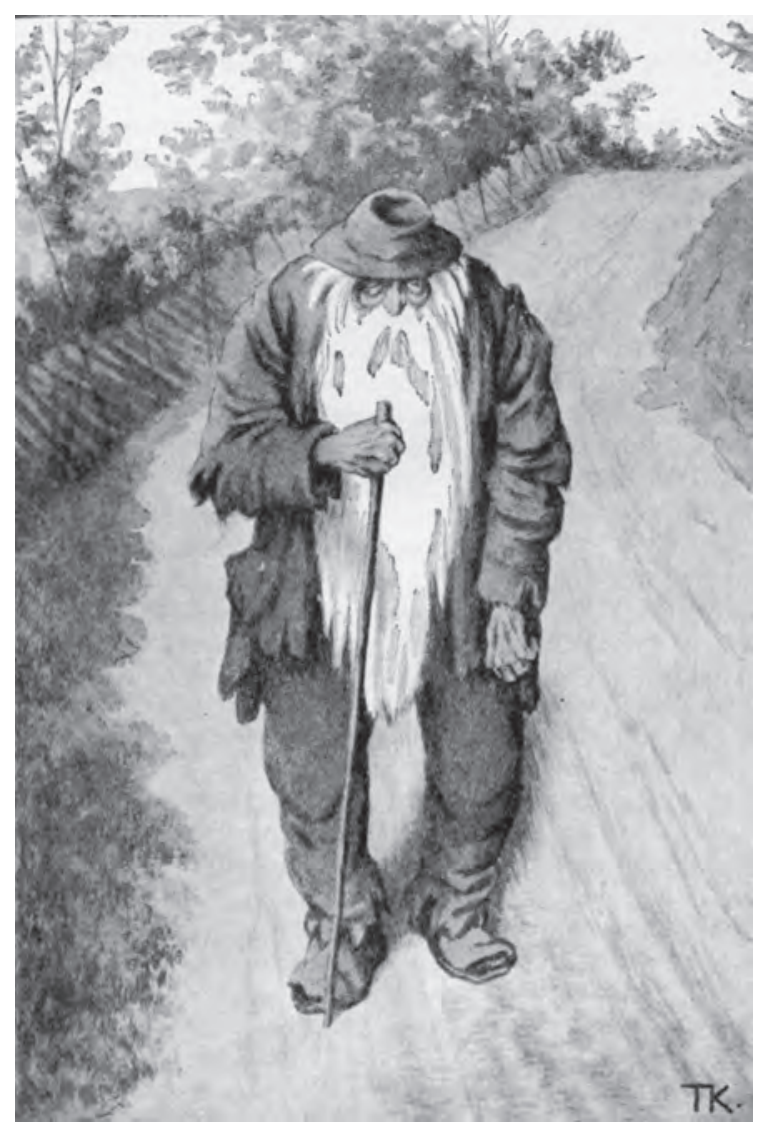

«Alle undret seg over denne skikkelsen som gikk der og så ut som en folkeskremme». Theodor Kittelsens illustrasjon til Asbjørnsen og Moe-eventyret «Venner i liv og død». 
Av teksten går det fram at den døde ikkje lenger held til i grava på kyrkjegarden. Grava er berre døra til ein eksistens i den andre heimen, dvs. himmelen. Himmelen er kort skissert som eit stort vatn «så lyst og blankt at brudgommen ikke tålte å se på det». At nettopp det skinande lyset representerer både himmelsk og jordisk venleik, er i samsvar med mellomalderens estetikk (Eco, 1986, s. 43-51). Vegen til himmelen går gjennom stummande mørker, kjerr og myrer, noko som assosierer til Olav Åstesons lange vandring i skirselden i «Draumkvedet». Dei to buskapane skal vi altså oppfatte som likningar - menneske med totalt ulik innstilling til livet, noko som får konsekvensar i den andre heimen. Truleg er likningane lånt frå Første Mosebok. Her blir det fortalt at farao drøymer om sju feite kyr som stig opp av Nilen. Deretter følgjer sju magre kyr, og desse magre kyrne sluker dei sju feite kyrne utan at det kan merkast på dei. Farao skjønar ikkje kva draumen varslar, og Josef forklarer då at dei sju feite kyrne er eit uttrykk for sju gode år, mens dei sju magre kyrne står for sju uår, som skal koma etter dei gode åra. Sentralt i eventyret er vidare tidsdimensjonane, dette at jordisk tid er så totalt annleis enn himmelsk tid. Jordisk tid er kortvarig og avgrensa til det enkelte mennesket sitt liv, mens himmelsk tid varer evig. Salme 90, som ligg til grunn for eventyret, slår dette fast.

Det er altså mogeleg for eit vanleg menneske å krysse grensa til dødsriket og koma attende, seier eventyret. Av handlinga går det fram at det finst eit godt liv i himmelen, der det er så strålande vakkert at det ikkje kan skildrast av noko jordisk vesen. Vegen dit går gjennom skirselden, der menneske som har handla urett i levande live, får si straff. Men kva får brudgomen eigentleg ut av besøket i den andre heimen? Det er ikkje til å koma frå at han forlèt kjærasten, foreldre, vener, slekt på sjølve bryllaupsdagen. Når han endeleg kjem attende, har livet gått frå han, og han kjenner seg ikkje att nokon stad. Moralen synest å vera at det jordiske livet har verdi i seg sjølv. Eit vakkert liv på den andre sida av grava finst, men ein bør ikkje freiste å koma dit før tida er inne.

\section{Munken og fuglesongen}

Som nemnt var det berre unntaksvis at nokon kom direkte til himmelen, slik profeten Elia gjorde. Han fór til himmelen i ei stridsvogn med 
eld og hestar, blir det fortalt i Andre Kongebok i Bibelen. Munken i det følgjande eventyret kjem dit på ein meir diskre måte. Han går ein tur i skogen og får høyre ein fugl som syng så urimeleg vakkert. Munken står og lyder på fuglesongen og tenkjer at han vil sjå denne fuglen. Dermed følgjer han etter fuglen, lenger og lenger inn i skogen. Men når han endeleg kjem attende til klosteret, er det ingen der som kjenner han, og ikkje kjenner han nokon sjølv heller:

Han hadde ikkje lagt merke til kor tida hadde fare. Han bad om losji for natta, og det fekk han. Men då dei kom til honom morgonen etter, så var det berre mold att i senga der han hadde lege. Han hadde lote koma att med sine jor-diske løyvor [restar], berre sjela fekk koma inn i himmerike. (Strompdal, 1929, s. 59)

Det er nærliggjande å oppfatte fuglen som ein himmelfugl. I folketradisjonen kan kvite fuglar og særleg duer symbolisere den heilage ande, og ikkje minst menneskesjeler. I ein nordlandsvariant til «Venner i liv og død» blir hovudpersonen ført til skirselden, der han får beskjed om å ta med seg to fuglar i eit klede. Utanfor porten slepper han så fuglane fri, og to kvite duer flyg sin veg «med lysteligt kvidder. «Du vidste ikke, hvem de fugle var, som du der bar ud,» sagde den døde; «det var din fars og mors sjæle, som du nu han frelst»» (Hodne, 1998, s. 185). Fuglesongen er det rimeleg å oppfatte som eit uttrykk for himmelsk musikk. Munken er nok velkjend med vakker musikk, og har sikkert mang ein gong sunge gregoriansk song i klosteret. Men dette er song på eit anna nivå, forstår vi.

Når det gjeld tidsmotivet i denne teksten, minner det om Asbjørnsen og Moes eventyr. Poenget er også her at himmelsk tid varer evig, mens tida på jorda er avgrensa til nokre få tiår. Menneskets feste i det jordiske kjem til uttrykk i molda som ligg att etter den døde munken, mens fuglesongen altså representerer den himmelske tidsdimensjonen. Men vi får ikkje inntrykk av at munken har skusla bort livet sitt, jamvel om han forlèt klosteret og gjev seg på vidvanke i skogen. Kanskje skal vi oppfatte munken som eit unntak og eventyret som eit mellomaldersk exemplum, ei moralsk-didaktisk forteljing? 


\section{I lys av visjonen}

Visjon tyder synsoppleving, framtidssyn, religiøs openberring. I mellomalderen fanst det mange litterære tekstar som vart kalla visjonar, og som formidlar ei religiøs openberring, ei religiøs oppleving. Visjonane - slike som Tundals visjon, Gottskalks visjon og Thurkills visjon - vart omsette til fleire europeiske språk, deriblant norrønt, og vart lesne høgt i kyrkjer og kloster. Slik kom visjonane til å inspirere til nydikting, både på vers og prosa. Den mest kjende norske visjonsteksten av denne typen er utan tvil «Draumkvedet». Det er ein visjonsballade som etter alt å døme vart til i mellomalderen ein gong, kanskje på 1300-talet, og som levde eit langt liv i munnleg tradisjon før den vart skriven ned på 180o-talet, hovudsakleg i Telemark. Moltke Moes restituerte tekst på 52 strofer er den mest kjende tekstforma av «Draumkvedet», men her tek eg utgangspunkt i varianten etter Maren Olsdotter Ramskeid, som song den beste av Draumkvede-variantane (Jonsson \& Solberg, 2011, s. 334-337).

Hovudpersonen i «Draumkvedet» er Olav Åsteson. Olav fell i svevn på julekvelden. Det er ingen vanleg svevn, men ein langvarig, ekstatisk svevn - sterkan svevnen - og når han endeleg på trettandagen vaknar, skundar han seg til kyrkja for å fortelja kyrkjelyden om den religiøse openberringa han har hatt. Her stiller han seg i kyrkjedøra slik den skulle gjera som hadde noko viktig å leggja fram. Olavs forteljing om kva han har opplevd i draume, er kjernen i balladen. Olavs sjel har vore på ei lang reise i dødsriket. Han har sett syndarar bli straffa i skirselden, han har skjøna verdien av sosial medkjensle, han har møtt sjølve himmeldronninga, jomfru Maria, han har opplevd det dramatiske møtet på domedag, der erkeengelen Mikael kallar syndesjelene fram:

Men då skalv alle syndesjelene,

som ospelauv for vinde,

og kvar den, kvar den sjel der var,

ho gret for syndene sine.

Og det var sankte såle-Mikkjel,

han vog med skålevekt.

Så vog han alle syndesjelene, 
bort til Jesum Krist.

(Solberg, 2003, s. 71)

Det kan synast overraskande at alle syndesjelene blir frelste, og det er ikkje i samsvar med mellomalderteologien. Men vi må hugse på at sjelene har vore gjennom ein lang reinsingsprosess i skirselden før dei kjem så langt som til domen. I Draumkvede-tradisjonen høyrer vi om drapsmenn, gjerrigknarkar, folk som har flytta grensemerke, og folk som har gift seg i strid med kyrkjelege reglar. Alle får dei sine straffer. Poenget er nok at nettopp sankte såle-Mikkjel [«sjele-Mikael»] spelar ei så viktig rolle i domsscenen. Erkeengelen Mikael hadde til vane å hjelpe syndarar meir enn dei hadde fortent. I mellomalderkunsten blir han gjerne framstilt ståande med ein finger oppunder vekstskåla med syndesjeler, slik at syndene ikkje skulle tyngje for mykje på skåla.

Brudgomen i Asbjørnsen og Moes eventyr har med seg ein følgjesvein på vandringa $\mathrm{i}$ «den andre heimen», og i Tundals visjon, som «Draumkvedet» delvis byggjer på, viser ein engel veg for visjonæren. Korleis kan det ha seg at Olav Åsteson må greie seg på eiga hand? Dei første strofene i «Draumkvedet» strekar under at Olav er ein uvanleg lovande ung mann «han var som ein seljerunne». Foreldra er glade i han, heiter det, ein sjeldan karakteristikk i balladediktinga. I nokre variantar blir Olav kalla nytan drengen, dvs. ein uvanleg dugande mann. Han går kledd i skarlak og står såleis høgt sosialt. Alt dette set Olav Åsteson i ei særstilling, skulle nokon finne fram i dødsriket, måtte det vera han.

Tundals kropp ligg kald og død frå onsdag middag til laurdag ettermiddag, heiter det. Berre på venstre side av bringa kan venene hans kjenne litt varme (Dietrichson, 1984, s. 19). Olavs vandring i dødsriket varer atskillig lenger, men verken i Tundals visjon eller i «Draumkvedet» har det noko å seia at visjonæren går over i ein annan tidsdimensjon og vender attende. Det ser ut til å vera samsvar mellom dei to tidsdimensjonane. Ei anna sak er at Olav sjølv må ha opplevd den pinefulle vandringa i dødsriket som langvarig. For ikkje å snakke om syndarane Olav møter på sin veg, dei må ha opplevd tida i skirselden som nærmast uendeleg.

Når Olav vaknar etter den ekstatiske svevnen, salar han straks hesten sin og rid til kyrkja. Der stiller han seg i kyrkjedøra og gjev presten følgjande klare melding: 
«No stend'e du for altaren, og legg ut teksten din.

Så stend’e eg i kyrkjedøri,

fortelje vil eg draumen min.»

(Solberg, 2003, s. 65)

Den antitetisk utforma strofa kan tolkast som om Olav tek eit oppgjer med presten, som om draumen Olav nå vil leggja fram, er viktigare enn prestens tekstlesing. Kanskje er det slik. Presten har ikkje vandra i dødsskuggens dal, men det har Olav Åsteson gjort. Han kjem med ferske inntrykk frå «den andre heimen» og veit ikkje minst kva for pinsler som ventar i skirselden. Men pinslene kan avgrensast i tid dersom menneska lever eit rett kristent-moralsk liv, slik dei såkalla «sælestrofene» i «Draumkvedet» peikar på, med si understreking av at ein vart sæl (salig) ved å gje almisser til dei fattige:

Sæl er den i fødesheimen,

den fattige gjev'e korn.

Han tarv ikkje reddast på Gjeddarbrui,

for kvasse stutehorn.

(Solberg, 2003, s. 68)

Mellomalderkyrkja ynskte å ha kontroll over etterlivet og særleg skirselden, og teologane visste sjølvsagt at ingen greidde å leva kristent-moralsk rett. Men mykje kunne rettast opp dersom folk var viljuge til å betala kyrkja for messehald og bøner, og gav almisser (Le Goff, 1992, s. 74-76). Slik vart læra om skirselden ei viktig inntektskjelde for kyrkja i seinmellomalderen. Men dette står det ingenting om i «Draumkvedet», som kan oppfattast som eit motinnlegg mot offisiell katolsk lære.

\section{Til slutt}

Ovanfor har vi sett fleire døme på kor stor rolle dei døde og livet etter døden spela for dei som levde i det førmoderne samfunnet. Grensa mellom levande og døde var tydeleg, men ikkje uoverstigeleg. Ved at enkelte døde kom attende som gjengangarar, og ved at nokre utvalde fekk visjonære innsyn $i$ «den andre heimen», vart det skapt eit motbilete til kvardagen. 
Av folketradisjonen får vi inntrykk av at dei døde kunne verke skremmande, dei dødes rike var ingenting å trakte etter. Men likevel kunne motbiletet fungere som korrektiv til gjeldande samfunnsordning, som ei påminning om korleis dei levande helst burde leva.

\section{Referansar}

Alver, Brynjulf, et al. (Red.) (1974). Norsk eventyrbibliotek. Band 5. Oslo: Det Norske Samlaget.

Asbjørnsen, Peter Chr., \& Moe, Jørgen (1978). Samlede eventyr 1-3. Oslo: Gyldendal. Bibelen. (2011). Det gamle og Det nye testamente. Oslo: Bibelselskapet.

Dietrichson, Jan W. (Red.) (1984). Tundals visjon. Oslo: Aschehoug. Thorleif Dahls Kulturbibliotek.

Eco, Umberto (1986). Art and Beauty in the Middle Ages. New Haven og New York: Yale University Press.

Espeland, Velle (2002). Spøkelse! Hvileløse gjengangere i tradisjon og historie. Oslo: Humanist Forlag.

Grambo, Ronald (1991). Gjester fra graven. Norske spøkelsers liv og virke. Oslo: Ex Libris Forlag AS.

Greenblatt, Stephen J. (1992). Learning to Curse. Essays in Early Modern Culture. New York og London: Routledge.

Hagberg, Louise [1937] (2016). När döden gästar. Svenska folkseder och svensk folktro $i$ samband med död och begravning. Stockholm: Ersatz.

Hodne, Ørnulf (1992). De dødes gudstjeneste. Et gammelt sagn i nytt lys. Norveg, 35: Universitetsforlaget.

Hodne, Ørnulf (1998). Det norske folkeeventyret. Oslo: Cappelen.

Jonsson, Bengt, \& Solberg, Olav (2011). «Vil du meg lyde». Balladsångare i Telemark på 18oo-talet. Oslo: Novus.

Kvideland, Reimund, \& Sehmsdorf, Henning K. (Red.) (1988). Scandinavian Folk Belief and Legend. Oslo: Norwegian University Press.

Le Goff, Jacques (1992). The Medieval Imagination. Chicago og London: The University of Chicago Press.

Midbøe, Hans (1946). Romantikkens balladediktning. Oslo: Gyldendal.

Nicolaissen, Olaus (1887). Sagn og eventyr fra Nordland. Anden Samling. Kristiania: Malling.

Petzoldt, Leander (1968). Der Tote als Gast. Volksage und Exempel. Helsinki: Academica Scientiarum Fennica.

Solberg, Olav (Red.) (2003). Norske Folkeviser. Våre beste ballader. Oslo: Aschehoug. 
Solberg, Olav (Red.) (2008). P. Chr. Asbjørnsen. Norske Huldreeventyr og Folkesagn. Oslo: Det Norske språk- og litteraturselskap.

Storaker, Johan Th. (1921). Tiden i den norske folketro. Kristiania: Norsk Folkeminnelag.

Strompdal, Knut (1929). Gamalt frå Helgeland. Oslo: Norsk Folkeminnelag. 



\title{
KAPITTEL 4
}

\section{Religiøse forståelser av døden}

\author{
Geir Winje \\ Universitetet i Sørøst-Norge
}

\begin{abstract}
Summary: In the first part of this essay, I give a brief overview of how death is understood in the most numerous religious communities in Norway. Two main categories are Western religions, with a linear understanding of time and life, versus Eastern religions, based on a cyclic understanding. However, as modernity paved way for new attitudes in Western culture towards e.g. reincarnation, this model does not fit any longer. Consequently, the second part of the essay deals with a third main category: modern, or rather late modern, religiosity, characterized by eclecticism. In the third and final part of the essay, I illustrate and colour this model by comparing three tales about death, each one corresponding to one of the main categories.
\end{abstract}

Keywords: death, halloween, modernity, religion, vulan

\section{Innledning}

De fleste religioner inneholder teorier som motsier døden og har programmer for å overvinne den (Davies, 2002; Garces-Foley, 2015; Oestigaard, 2004). Å dø kan forstås som å fødes inn i en ny tilværelse; jamfør katolske helgener som i hovedsak feires på sin dødsdag, ikke på sin fødselsdag. Dette kapittelet undersøker hvordan religiøse forståelser av døden endrer seg i Norge og andre vestlige land. Jeg gjør først rede for forståelser av døden i et utvalg tradisjonelle religioner, både fordi de utgjør et nødvendig bakteppe for å kunne se og forstå endringene, og fordi en slik oversikt har verdi i seg selv. Deretter trekker jeg frem noen religiøse nyskapninger fra de siste 150 årene, med vekt på hvordan de kan forstås som konsekvenser av nye kombinasjoner, ikke minst mellom en vestlig forståelse av tid og utvikling og en østlig tro på reinkarnasjon. Til sist nærleser jeg tre fortellinger om døden som korresponderer med 
religioner eller religiøse strømninger som er tatt opp tidligere i kapittelet. Dette for å illustrere, men også nyansere, den mer teoretiske tilnærmingen. Hver av kapittelets tre hoveddeler belyser altså en problemstilling:

Del 1 - bakteppe: Hvordan forstås døden i tradisjonelle religioner som gjør seg gjeldende i Norge i dag?

Del 2 - hovedspørsmål: Hvordan forstås døden innenfor moderne religiøsitet?

Del 3 - nyansering: Hvordan forstås døden i fortellinger som korresponderer med vestlig, østlig og (sen)moderne religion/religiøsitet?

\section{Utvalg og metode}

Før jeg går inn i tematikken rundt død og religion, vil jeg gjøre rede for valgene mine angående hvilke religioner jeg trekker frem, hvorfor jeg trekker inn fortellinger, hvilke fortellinger jeg har valgt, og hvilke analytiske grep jeg tar.

Når jeg har valgt å se på kristendom, islam, buddhisme og hinduisme, er det fordi dette er de fire mest omfangsrike religionene i Norge og globalt. Ifølge Statistisk sentralbyrå har Den norske kirke oppunder 3,8 millioner medlemmer (www.ssb.no - tall for 2017 - lest 28.01.2018), altså 71,5 \% av Norges befolkning. Medlemstallet synker litt for hvert år, i likhet med de fleste andre kristne kirkesamfunn. To viktige unntak er den katolske og den ortodokse kirken, som i hovedsak vokser på grunn av innvandring (ibid. - det bor over 150 ooo katolikker og nesten 22000 ortodokse kristne i Norge). Av samme grunn bor det over 153 ooo muslimer, over 17 ooo buddhister og nesten 9000 hinduer her i landet.

Med den samme prosentvise fordelingen vil det i en skoleklasse med 20 elever være 14 eller 15 som tilhører Den norske kirke, samt én muslim, én katolikk og én som tilhører pinsebevegelsen eller et annet kristent trossamfunn. Tilhørigheten for de to siste elevene vil variere, men det er ikke usannsynlig at den ene er uten noen religiøs tilhørighet, mens den andre tilhører en «innvandrerreligion».

I media vektlegges gjerne forskjellene mellom islam og kristendom, men når det gjelder sentrale teologiske spørsmål, er likhetene flere enn 
ulikhetene. Det henger sammen med at både kristendom og islam religionshistorisk sett har sine røtter i jødedom. Forståelsen av døden er derfor i hovedsak den samme i disse tre religionene, som jeg stort sett omtaler som «vestlige». Med «østlige religioner» sikter jeg til hinduisme og buddhisme, som begge er store globalt, og som i Norge utgjør ganske store minoriteter. I samme kategori plasseres gjerne sikhismen, som i Norge har rundt 3650 registrerte medlemmer (ibid.). Selv om disse tre forfekter ulike menneskesyn, og dermed ulike forståelser av døden, forholder de seg alle til gjenfødsel.

Likhetene mellom religioner som plasseres i samme kategori, kan imidlertid overdrives. Det underkommuniseres for eksempel ofte hvor mye en vestlig religion som kristendom har felles med en østlig religion som hinduisme når de, som de to eneste verdensreligionene, forholder seg til Gud som har blitt menneske, jamfør begreper som inkarnasjon (fra latin: «i kjøtt») og avatar (fra sanskrit: «nedstigning»). Det er også interessant hvordan forkynnelsen i to så ulike religionsformer som theravada-buddhismen og islam dreier seg om å slippe straff i et helvete som skildres detaljert.

Nå er det under hundre år siden en lignende vektlegging av straffen i helvete preget kristen forkynnelse i Norge. Når den er tonet ned, henger det sammen med at den verken er kompatibel med naturvitenskap eller humanisme - den passer kort sagt ikke inn i det moderne. I tillegg til kategoriene vestlig og østlig religion bruker jeg derfor «førmoderne», «moderne» og «senmoderne» om tre grunnholdninger som korresponderer med mentalitetshistoriske epoker.

En førmoderne forståelse av døden kjennetegnes blant annet av at den er gitt, og at religiøse autoriteter sørger for at den håndteres i samsvar med gammel tradisjon og rett lære. Det førmoderne er særlig representert ved religioner og trossamfunn. «Det moderne» viser til en historisk epoke som tok til på 180o-tallet (noen vil si renessansen), og som slår ut i sekularisering, humanisme, naturvitenskap, demokrati og fremtidsoptimisme. Mange kombinerer de to mentalitetene: De møter en klinisk død på sykehuset og tar et kultisk farvel med den døde i kirken noen dager senere. «Det senmoderne» brukes her om modernitetens seneste fase, som korresponderer med tiden etter annen verdenskrig. En senmoderne 
mentalitet skiller seg fra den tidlige moderniteten ved et pessimistisk syn på fremtiden. Tillit til vitenskapen er erstattet med skepsis, og organisert religion fortsetter å tape terreng. Lykken, fremtidshåpet og religionen er privatisert, og den enkelte kan utvikle sin egen forstålse av døden, gjerne med elementer både fra det førmoderne og det moderne.

Jeg har valgt å nyansere den teoretiske fremstillingen ved hjelp av tre til dels folkelige fortellinger om døden. De er ikke uten videre sammenlignbare, da to av dem inngår i førmoderne, kollektive kontekster og er knyttet til hver sin religiøse høytid, mens den tredje har blitt til i en senmoderne, individualistisk sammenheng. Dessuten er to av fortellingene i utgangspunktet muntlige, mens den tredje er nedskrevet i en hellig tekst som resiteres under den årlige feiringen av vulan i Vietnam og andre østasiatiske land. Når jeg likevel har valgt å sammenligne dem, er det fordi de har stor utbredelse og appell. Selv om de kan knyttes til hver sin religion, kan de ikke representere hver sin religion. De lever sitt eget liv og representerer kun seg selv, men nettopp derfor kan de i større grad enn mange andre kilder motsi, og dermed nyansere, de mer teoretiske perspektivene.

Alle tre fortellingene tematiserer døden og det som kommer etter døden. De handler også om motstand og aksept. I en analyse er det derfor interessant å forsøke å avdekke de maktstrukturene som faktisk gjelder. For å få tak i disse strukturene leser jeg tekstene i lys av en enkel versjon av Greimas' aktantmodell (lansert i 1966; Hébert, 2006):

- The axis of desire: (1) subject / (2) object (...)

- The axis of power: (3) helper / (4) opponent (...)

- The axis of transmission (the axis of knowledge, according to Greimas): (5) sender / (6) receiver

Modellen omfatter tre sentrale akser, hvorav den første («axis of desire» eller prosjektaksen) gjelder hovedpersonens (subjektets) prosjekt, nemlig å erverve et objekt - i dette tilfellet å unnslippe døden eller helvete. Langs de to andre aksene finner vi «hjelper» versus «motstander» og "giver» versus «mottaker». I en enkel kristen modell vil Gud være både giver og hjelper, og fortellingens happy end finner sted når subjektet mottar 
objektet fra ham. Fullt så enkelt går det ikke for seg i de fortellingene jeg har valgt.

\section{Del 1: Tradisjonelle religiøse forståelser av døden - i vest og i øst}

Jeg tar som nevnt først for meg problemstillingen: Hvordan forstås døden $i$ tradisjonelle religioner som gjør seg gjeldende i Norge i dag? En vanlig måte å kategorisere tradisjonelle religioner på er å dele dem i én østlig og én vestlig gruppe. De østlige religionene har en syklisk tidsforståelse; alt gjentas, også menneskelivet. De vestlige religionene opererer derimot med en lineær forståelse av historien og menneskelivet, som begge har én begynnelse og én slutt.

Ifølge en jødisk-kristen modell lever hvert menneske sitt ene liv, og døden er endelig i den forstand at de døde er ikke-eksisterende og uten bevissthet. Men samtidig er ikke døden endelig, for på dommens dag vil alle vekkes til live igjen. Folkelig kristendom er ikke like stringent som kirkens formelle lære, så i praksis har mange troende gjennom kristendommens to tusen år lange historie forholdt seg til de døde som om de levde videre i en annen dimensjon. På 1200-tallet formaliserte den katolske kirken den allerede utbredte troen på at mennesket umiddelbart etter sin død må oppholde seg en viss tid i skjærsilden.

Mange surer i Koranen slår også fast at alle skal dø og gjenoppstå. En ofte sitert ayat (vers) er: «Hvert menneske vil smake døden. På oppstandelsens dag vil dere få fullt oppgjør» (sure 3,185 - alle koransitatene er hentet fra Einar Bergs oversettelse, utgaven fra år 2000, slik den er tilgjengeliggjort på islam.no). I en modell basert på hadith (tradisjonen etter Muhammad) og tidlig islamsk teologi er imidlertid den døde ved bevissthet i barzach (tiden mellom dødsøyeblikket og dommens dag; Eidhamar, 2017, s. 215; se også Smith \& Haddad, 2002). Etter gravferden hentes den døde fra graven av dødsengelen Azrail, som bringer ham til paradiset, der han enten slipper inn eller stenges ute. På dommens dag gjenforenes han så med kroppen sin.

Det poengteres for øvrig i gravferdsritualene i vestlige religioner at mennesket er skapt av jord, og at det på ingen måte er hellig eller har 
en guddommelig sjel. Under jordpåkastelsen siteres den jødiske Toraen (Moseloven) av den kristne presten: «Av jord er du kommet, til jord skal du bli, av jord skal du atter oppstå» (jf. Første Mosebok 3,19). Muslimsk gravferd ledes gjerne av en imam (bønneleder i moskeen) som under jordpåkastelsen sier omtrent det samme: «Av jord har Vi skapt deg og til den lar Vi deg vende tilbake og av den skal Vi bringe deg frem en gang til» (Neegaard, 1993, s. 56; jf. Koranen 20,55 - pronomenet «Vi» brukes når Guds direkte tale gjengis).

Både kristendom og islam fremsto i sine tidligste faser som apokalyptiske eller dommedagsorienterte. Dette i motsetning til jødedommen, som i større grad handler om det dennesidige i form av folkets overlevelse. I de eldste surene (kapitlene) i Koranen er det særlig tre budskap som ofte gjentas: Det finnes bare én Gud, Muhammed er hans profet, og dommedag nærmer seg. Og i det første brevet til tessalonikerne, som sannsynligvis er den eldste teksten i Det nye testamente, er dommedag så nær forestående at Paulus regner med at mange troende kommer til å rykkes bort før de rekker å dø en naturlig død (kap. 4 - alle bibelsitater er hentet fra Bibelselskapets utgave på bibel.no - sist lest 13.02.2018):

For når befalingen lyder, når erkeengelen roper og Guds basun høres, da skal Herren selv stige ned fra himmelen, og de døde i Kristus skal stå opp først. Deretter skal vi som er igjen og ennå lever, bli rykket bort sammen med dem i skyene for å møte Herren i luften. Og så skal vi være sammen med Herren for alltid (...)

Både kristent og muslimsk menneskesyn innebærer altså at mennesket dør når det dør. Det lever ikke videre, verken som engel eller spøkelse, og det gjenfødes verken som dyr eller menneske. Innenfor islam er imidlertid «livet i graven» preget av en form for bevissthet, og i både jødisk, kristen og muslimsk folketro finner vi forestillinger om de dødes fortsatte eksistens. I bibeltekstene kan døden assosieres med søvn (se f.eks. Paulus' første brev til korinterne 15,18), men oftere med «dødsriket» (Hades), der de døde venter på å vekkes til live igjen på dommens dag. Forestillingen om et dødsrike er også en forutsetning for troen på at Jesus i dagene mellom sin død og sin oppstandelse forkynte evangeliet «for de døde» (jf. Peters første brev 4). 
I de østlige religionene er gjenfødsel et grunnleggende vilkår. Ordet «gjenfødsel» er en oversettelse av sanskrit-begrepet samsara, som har grunnbetydningen «strøm» (som vann i en elv). Samsara viser til den materielle verden, der alt endrer seg hele tiden, og der intet er fast eller varig. Den enkeltes gjenfødsel styres av karma, som er sanskrit for «handling» og «konsekvens av handling». Alt en gjør i dette livet, får nemlig konsekvenser - enten i dette eller i det neste livet. I tradisjonell hinduisme er det atman, sjelen, som gjenfødes og lever videre i en ny kropp. Kroppen er timelig, men atman er evig. Når kroppen kremeres, frigjøres atman fra materien, men finner snart en ny kropp å gi liv til. Etter en lang rekke med liv vil atman til sist vende tilbake til brahman (Gud, «verdenssjelen»), som atman opprinnelig er ett med eller del av.

Perioden mellom to liv anses som farefull. Noe av det verste som kan skje, er at den døde ikke finner noen kropp å leve videre i. Dersom han heller ikke er klar for å smelte sammen med brahman, vil han leve videre uten kropp, med andre ord som en ånd eller et spøkelse (Jacobsen, 2003, s. 219 ff.). De etterlatte ofrer ris for å hjelpe den døde med å få en fysisk kropp igjen. Ofring av mat genererer god karma, og karma kan videreformidles.

Buddhismen var i utgangspunktet en hinduisk reformbevegelse. Den viktigste forskjellen mellom de to religionene er tydeliggjort i det buddhistiske begrepet anatman («ikke-sjel»). Buddha tok nemlig avstand fra den hinduiske læren om atmans enhet med brahman. Han hevdet at mennesket ikke hadde noen guddommelig sjel eller kjerne, men at dets dypeste drivkraft var begjær. Det er ikke sjelen, men begjæret, som i form av fem skandaer («opphopninger» av begjær knyttet til sanseinntrykk) blir gjenfødt. Den som begjærer noe i samsara, vil bli gjenfødt i samsara. Livet som menneske er imidlertid bare én av fem eller seks mulige tilværelsesformer. En kan også bli gjenfødt som en gud, en sulten avdød ånd, et dyr eller et vesen i ett av mange helveter (Jacobsen, 2011, s. 52).

\section{Del 2: Moderne religiøse forståelser av døden}

Det moderne førte med seg sekularisering - eller sekularisering var en forutsetning for moderniteten. Når samfunnet «avkristnes», åpner det for ateisme og positivisme, men også for religiøse nyskapninger. Modernitetens 
utforskende impuls førte ikke bare til at naturen ble undersøkt og kunsten ble eksperimentell. Den viser seg også i at vestlige mennesker dro østover ikke for å misjonere, men for å studere religioner. I 1875 ble Teosofisk samfunn stiftet, med madame Blavatsky som det mest profilerte medlemmet. Blant samfunnets formål kan nevnes: « $\AA$ oppmuntre til sammenlignende studier i religion, filosofi og vitenskap» og «å undersøke naturens skjulte lover og menneskets latente krefter» (Winje, 1999, s. 202 - se også Gilhus \& Mikaelsson, 1998, 2005). Teosofene var pådrivere under etableringen av religionshistorie som universitetsfag. De ville påvise at religionene dypest sett gikk ut på det samme, at naturvitenskapen bekreftet religionene og vice versa. Et typisk eksempel finner vi i The Key to Theosophy (1889), der Blavatsky forklarer teosofien i spørsmål-svar-form:

ENQUIRER. But who is it that creates each time the Universe?

THEOSOPHIST. No one creates it. Science would call the process evolution; the pre-Christian philosophers and the Orientalists called it emanation: we, Occultists and Theosophists, see in it the only universal and eternal reality casting a periodical reflection of itself on the infinite Spatial depths. This reflection, which you regard as the objective material universe, we consider as a temporary illusion and nothing else. That alone which is eternal is real.

De forsto det slik at evolusjonsteorien (jf. Darwin) bekreftet den tradisjonelle, østlige læren om gjenfødsel, og etablerte dermed en vestlig variant av denne. En sentral bok i denne sammenhengen - både for teosofer og andre - var Bardo Thodol (Den tibetanske dødebok), som kom i engelsk oversettelse i 1927 (Kværne, 2005; Mathisen, 200o). Den fikk stor utbredelse, men fordi den historiske konteksten var ukjent for leserne, ble den tolket på mange og til dels svært fantasifulle måter (Kværne, 20oo). I The Psychedelic Experience. A Manual Based on the Tibetan Book of the Dead (Alpert mfl., 1964) ble den til og med forstått som en «reisehåndbok» for LSD-tripper.

Den tibetanske dødebok er egentlig den tekstlige delen av et langvarig dødsritual, der de gjenlevende ofrer for den døde for å hjelpe ham gjennom det nødvendige oppholdet i bardo, «mellomtilstanden» mellom to liv. Her møter den døde mange skremmende vesener som i Bardo Thodol 
forstås psykologisk, som projeksjoner av den avdødes nylig avsluttede liv (Mathisen, 2000, s. 53):
Nå som den sanne værens mellomtilstand [bardo] kommer til syne,
vil jeg ikke la meg styre av redsel for skremmende opplevelser.
Hva jeg enn møter, vil jeg gjenkjenne det som bilder skapt av meg selv, og vite at det er på denne måten mellomtilstanden kommer til uttrykk.
Jeg har nå nådd dette kraftfulle øyeblikk fylt med mening,
og jeg vil frykte hverken de milde eller de vrede guddommene, som er bilder skapt av meg selv.

Noen av disse tankene videreføres i dag innenfor New Age- eller alternativbevegelsen. Troen på reinkarnasjon har fulgt med yogakurs og gurubevegelser, så vel som med innvandring, som en selvsagt faktor (Jacobsen, 2011). Og selv om Teosofisk samfunn aldri ble stort i Norge, har den antroposofiske bevegelsen videreført et teosofisk menneskesyn basert på reinkarnasjon. Allerede for ti år siden viste flere spørreundersøkelser at rundt $25 \%$ av Norges voksne befolkning regnet med at dette livet var ett av mange (www.aftenposten.no/norge/i/8Qjvr/n-avfire-nordmenn-tror-pa-reinkarnasjon - lest 05.08.2017).

Moderne spiritisme, som også preget siste halvdel av 180o-tallet, representerte et noe annet syn på døden enn dem vi har sett på så langt (Kalvig, 2016). Spiritus (fra latin) kan oversettes med ånd, noe som indikerer et dualistisk menneskesyn: Mennesket er en ånd som lever videre selv om kroppen dør - som i østlige religioner. Men vestlig spiritisme er først og fremst en praksis som omfatter kommunikasjon med ånder, gjerne etter avdøde mennesker, som kontaktes eller tar kontakt. De vanligste kommunikasjonsformene på 180o-tallet var bankelyder, åndebrett (oujaboard) med bokstaver, tall og «ja»- og «nei»-felt, brev som materialiserte seg, samt medier - det vil si mennesker som i transe fungerte som formidlere eller mellomledd mellom de døde og de levende.

Selv om spiritismen videreførte førmoderne forestillinger og praksiser, hadde den også et moderne preg - fordi deltagere og observatører forsto det som skjedde under seansene empirisk, og anvendte naturvitenskapelig terminologi. De var opptatt av viten og ikke av tro, og tok i bruk siste nytt innen teknologi for å dokumentere at de døde levde videre i en 
parallell tilværelse som var så nær at kontakt var mulig. Ånder (avdøde) som materialiserte seg, og møbler som beveget seg i løse luften, ble fotografert, og det ble gjort lydopptak under seanser der en kunne høre de dødes stemmer. Parapsykologi ble et nytt fagfelt som skulle undersøke fenomener som spiritisme, telepati og clairvoyance (klarsynthet) på en naturvitenskapelig måte.

På 180o-tallet ble det også etablert flere nye trossamfunn som svarte på modernitetens utfordringer på ulike måter. Noen av dem forsto seg selv som kristne kirker med rom for spiritisme, da medlemmene så det som Guds vilje at levende og døde kommuniserte med hverandre og viste hverandre omsorg. Mange av dem var inspirert av Allan Kardec, sannsynligvis den viktigste aktøren innenfor organisert spiritisme på denne tiden. Han ville harmonisere spiritisme og kristendom, og inkorporerte også reinkarnasjon i sin lære. I dag er spiritismen utbredt over hele verden. Betegnelsen «spiritualisme» brukes gjerne om spiritistiske trossamfunn som ikke knytter seg til Kardec.

Også trossamfunnene Jehovas vitner (etablert 1870) og Jesu Kristi Kirke av Siste Dagers Hellige (mormonene, etablert 1830) kan til dels forstås som responser på spiritismen (Winje, 1999). Førstnevnte bygger på et fundamentalistisk bibelsyn og tar derfor alle Bibelens utsagn om spiritisme og åndemaning bokstavelig: «Det skal ikke finnes hos deg noen som (...) rådspør et åndemedium, eller (...) noen som spør de døde. For enhver som gjør disse ting, er en vederstyggelighet for Jehova» (Ny verden-oversettelsen 1996, Femte Mosebok 18,10, se også Tredje Mosebok 19,31 og Paulus' brev til galaterne 5,19-21). Advarsler mot spiritisme er et av hovedsporene i de eldste årgangene av Vakttårnet, som er Jehovas vitners viktigste organ. Fordi de døde er uten bevissthet frem til de gjenoppvekkes på dommens dag, tilbakevises også nær-døden-opplevelser. «De levende vet at de skal dø; men de døde vet slett ingen ting» (Forkynneren 9,5).

Mormonene nevnes her fordi de forholder seg til de døde på en måte som kan minne om spiritisme. Trossamfunnet lærer at de døde lever videre uten kropp i en åndeverden. De tar riktignok ikke kontakt med de levende, men de levende hjelper de døde, først og fremst ved å la seg døpe på vegne av avdøde slektninger (se Paulus' første brev til korinterne 15,29). 
Både mormonene og spiritistiske grupper bruker uttrykk som «den andre siden» om åndenes «sted».

Nye forståelser av døden fører med seg behov for nye gravskikker, noe Gunnar Neegaard tok opp i 1993, først og fremst i lys av innvandring (s. 41):

Etter hinduistisk skikk skal asken spres i rennende vann. Ettersom askespredning ikke er tillatt i Norge, må man avfinne seg med at urnen må gravsettes. Alternativt kan pårørende velge å bekoste frakt av urnen til India, slik at innholdet kan spres på Ganges, indernes hellige elv.

Året etter uttalte Kirkemøtet seg negativt om askespredning, men i 1996 ble det tillatt etter søknad til fylkesmannen. Siden har det vist seg at behovet for askespredning ikke bare gjelder nordmenn med bakgrunn i østlige tradisjoner. Ifølge NRK ønsket nemlig hver tiende nordmann askespredning i 2014. Ida Marie Høeg ved Senter for kirkeforskning uttalte i den forbindelse:

Sterk samhørighet med naturen er bare én forklaring på at mange ønsker dette. En annen viktig forklaring er at en del av oss ikke har den samme tilknytningen til de gamle norske gravskikkene. Folk er mer åpne for nye impulser og ønsker å gjøre det på [sin] egen måte (www.nrk.no/norge/flere-onsker-a-spre-askenetter-dod-1.11520434 - lest 17.03.2017).

I samme sending intervjues en person som har spredd sin avdøde fars aske, men som samtidig etterlyser muligheten til å ha farens navn på en gravstein.

«Askespredning er et alternativ til gravlegging. Det gis derfor ikke mulighet for $\stackrel{a}{ }$ få navn og data på gravminne på kirkegården dersom man har valgt dette», er begrunnelsen på Kulturdepartementets nettsider (ibid.).

Denne lille gravskikkfortellingen illustrerer hvordan førmoderne, moderne og senmoderne mentaliteter er tungt til stede i samfunnet. Når kirkemøtet i 1994 avviser den fremmede skikken, utøves makt basert på religion - på førmoderne vis. Når departement og fylkesmann overprøver kirkemøtet, bruker de makt for å sikre religionsfrihet, som må sies å 
være en moderne verdi. Men når de samme aktørene utøver makt for å regulere enkeltmenneskets frihet til å kombinere elementer fra forskjellige dødsritualer, fremstår det moderne som formynderi.

\section{Del 3: Tre fortellinger om døden}

Jeg har valgt tre fortellinger som korresponderer med ulike forståelser av døden. Som jeg har gjort rede for ovenfor, er de ikke uten videre sammenlignbare, men de har til felles at hovedpersonen eller subjektet kjemper imot død og/eller helvete. Selv om fortellingenes kontekst er kristendom, buddhisme og alternativ religiøsitet, er de ikke representanter for disse trosretningene.

Den vestlige fortellingen om Jack O'Lantern har mye til felles med det norske folkeeventyret om «Smeden som de ikke torde slippe inn i helvete». Den representerer ikke noen formell, kirkelig kristendomsform, men eksemplifiserer folketro og underholdning i en førmoderne kristen kultur: Den irske smeden Jack var en drukkenbolt som en gang lurte djevelen til å la seg fange i pengepungen sin. Djevelen slapp ikke fri før han hadde lovet Jack å vente ett år før han kom tilbake for å kreve sjelen hans. $\mathrm{Da}$ året var omme, kom djevelen tilbake, men denne gangen fanget Jack ham i et eple, og slapp ham ikke fri før han hadde lovet aldri mer å kreve Jacks sjel. Da Jack døde, ble han først avvist i himmelen fordi han hadde levd et syndig liv, og så ble han avvist i helvete fordi han hadde fått dette løftet av djevelen. Derfor vandret han hjemløs rundt i mørket i all evighet. For at han skulle få litt lys, ga djevelen ham et stykke glødende kull fra helvete. Det la Jack i en uthulet kålrot, i noen varianter av fortellingen en uthulet nepe. Hver halloween kan Jack O'Lantern ses der han vandrer omkring med lykten sin. Da svært mange irer utvandret til USA under hungersnøden i 1840-årene, ble fortellingen med på lasset, og høytiden ble amerikanisert. Blant annet ble lykten nå et uthulet gresskar.

Halloween (All Hallows' Eve) er på mange måter en kristen videreføring av den førkristne, keltiske høytiden samhain, som markerte at vinteren tok til. Da lå også grensen mellom de levende og de døde nede. På grunn av de germanske folkevandringene og andre historiske forhold fikk irsk kristendom en periode stor innflytelse over hele Europa, og rundt år 1000 
etablerte den irske høytiden seg i form av to katolske festdager som fremdeles eksisterer. Allehelgensdag markeres 1. november for alle de døde som på grunn av sitt hellige liv eller sin martyrdød lever videre nær Gud. De navngis i lange litanier, og det er vanlig å be dem om å gå i forbønn for seg. Dagen etter er alle sjelers dag, og her fokuseres det på alle døde mennesker. I Norge har ikke 2. november vært så viktig, men allehelgensdag har tatt opp i seg elementer fra alle sjelers dag. Da den sammen med en del andre helligdager ble tonet ned i 1770, forble den likevel viktig for mange, og deler av feiringen ble revitalisert etter kong Olavs død i 1991 (Aagedal, 1996, 2010). Halloween fremstår i dag som en kommersiell, amerikansk nykommer blant de norske merke- og helligdagene, men den er eldre enn mange er klar over. Høytiden, og med den fortellingen om Jack, inngår altså i flere historiske kontekster. Den tiltrekker seg dessuten barn og unge med behov for grøss, og gir en sjelden anledning til å tematisere døden.

Den buddhistiske, østlige fortellingen om munken Maudgalyayana (kortform: Mogallana) og moren hans er nedskrevet i den mahayana-buddhistiske Ullambana sutra (fritt oversatt: Loreteksten om frigjøring for dem som lider i helvete). Mogallana var en av Buddhas ti disipler, som alle ifølge de gamle tekstene hadde utviklet overnaturlige evner. Mogallanas evne var å kunne bevege seg mellom ulike verdener eller tilværelsesmåter (se ovenfor). Derfor hadde han møtt sin egen avdøde mor, som måtte være i helvete, der hun ble straffet for sin gjerrighet ved at alt hun fikk å spise, ble til glødende kull i det øyeblikket hun tok i det. Sønnen hentet ris til henne i menneskenes verden, men den ble også til kull da hun ikke ville dele den med noen. Mogallana visste ikke hva han skulle gjøre. Han kunne ikke hjelpe sin sultende mor så lenge hun ikke endret mentalitet, så han spurte Buddha om hjelp. Da lærte Buddha munkene hvordan de gjennom meditasjon kunne opparbeide et overskudd av god karma, som de så kunne dele med Mogallanas mor. Og så mediterte hele sanghaen (munkesamfunnet) hver dag mens den var samlet gjennom den tre måneder lange regntiden, og det langvarige ritualet ble avsluttet med et stort måltid for de døde, før munkens mor kunne forlate helvete som en gavmild kvinne.

Dette er et typisk mahayana-buddhistisk tema. Mahayana kan oversettes med «stor farkost» fordi denne retningen, som dominerer i Øst-Asia, 
inklusive Vietnam, vektlegger hvordan buddhaer og andre kan overføre god karma til dem som trenger det. Farkosten er stor fordi flere vil oppleve nirvana eller gjenfødes i et paradis, også de som ikke fortjener det.

Ullambana sutra blir resitert hvert år under vulan, som er den vietnamesiske betegnelsen på en høytid som feires over hele Øst-Asia ved regntidens avslutning $\mathrm{i}$ august. Høytiden kalles også ullambana (kortform: bon), «de dødes dag», «kinesisk halloween» og/eller «kinesisk morsdag». Denne dagen rettes oppmerksomheten mot foreldre - levende som døde - særlig mødre. Under feiringen i templene får barn med en mor som er i live, en rød rose av munkene, mens barn som har mistet moren sin, får en hvit rose.

Den siste fortellingen jeg har valgt, handler om en nær-døden-opplevelse (NDO), gjengitt i intervjuform i Magasinet Visjon nr. 1/2014 (magasinetvisjon.no/visjon/eben-alexander-himmelsk-reise/ - lest 02.10.2017). Eben Alexanders bok Proof of Heaven (Himmelen finnes, 2013), handler om den samme opplevelsen, som i store trekk faller sammen med tilsvarende opplevelser som først ble samlet og publisert av Raymond Moody i Livet etter livet (1996, først utgitt i 1975). Det reklameres da også for Alexanders bok på nettsteder som nettopp Life after life (lifeafterlife.com/ - lest 02.10.2017).

Det er visse opplevelser som går igjen i Moodys materiale, selv om han er nøye med å understreke at ingen av informantene har hatt alle disse opplevelsene. De døende som ikke døde likevel, rapporterer i ettertid om en følelse av fred og velvære, uten smerter, der bevisstheten virker uavhengig av kroppen og en opplever seg selv «utenfra», flyter i et mørke og beveger seg igjennom en slags tunnel. Der tunnelen tar slutt, møter de et gyllent lys, og noen ganger har de en form for kommunikasjon med dette lyset. I mange NDO-fortellinger inngår også det å gjenoppleve sitt eget liv, før det hele kulminerer i opplevelsen av å nærme seg en annen verden, som er vakrere enn den en kommer fra. Eben Alexanders fortelling skiller seg fra 1970-tallsfortellingene ved at kontrastene er mye sterkere:

Mens familien forberedte seg på at han skulle dø, var Eben i et eldorado av farger, lys og lyd. Mørket han hadde befunnet seg i, gikk i oppløsning. En levende lyd, den aller vakreste musikken han noen gang hadde hørt, strømmet mot ham. Han fløy, svevde over trær og enger, elver og fosser. En vakker pike med 
høye kinnben og dypblå øyne var ved hans side. Eben kommuniserte med orber [lysende kuleformete vesener] og andre lysvesener, og med det han kaller «om», eller Gud. Han forteller om en dyp innsikt i det som fins bakenfor alt. Han så høyere verdener som er usynlige for oss, og verdener som er synlige, men langt mer avanserte enn livet på jorden. (Nygaard, 2014)

Dette korte utsnittet er et godt eksempel på senmoderne, eklektisk religiøsitet. Her inngår elementer som umiddelbart gir assosiasjoner til hinduisme (mantraet «om»), vestlig religion (Gud), naturreligion (trær og enger), sjamanisme (sjelen reiser uavhengig av kroppen) og muligens UFO-religiøsitet (piken med høye kinnben, jf. Semjase; Winje, 1999, s. 306). Aller mest synes Alexanders fortelling å reflektere et gnostisk grunnsyn, der «høyere verdener» er virkeligere og vakrere enn «lavere verdener», og innsikt i det åndelige er mer verdifullt enn innsikt i det materielle. I den forbindelse gjøres det et nummer av at Alexander har naturvitenskapelig bakgrunn. Når han, en nevrokirurg som per definisjon er opptatt av kvantifiserbar empiri, påpeker at naturvitenskapen ikke er noe godt forståelsesverktøy, virker han troverdig:

I ettertid hadde han sterkt behov for å skrive og forstå, også fra hans vitenskapelige, nevrokirurgiske ståsted. Sammen med andre nevrokirurger og forskere har han analysert og reflektert over hypoteser som kunne forklare alt han opplevde, sett fra et klassisk vitenskapelig ståsted. Ingen av teoriene holdt mål. Eben konkluderte med at hjernen umulig kan ha fabrikkert de sterke opplevelsene. Hjernen hans fungerte ikke bare feilaktig, den fungerte ikke i det hele tatt. Den delen av hjernen som tar imot informasjon fra sansene og skaper verden vi lever i, ifølge medisinsk teori, var ute av drift. Likevel hadde han vært i live, og i høyeste grad bevisst, i et kjærlighetsfullt univers. (Nygaard, 2014)

\section{Hovedbudskapet er altså kjærlighet:}

Vi alle må søke å forstå hva uforbeholden kjærlighet er, og den enorme makten og kraften som ligger i kjærligheten. Kvinnen formidlet det slik: «Du er elsket og avholdt, inderlig og alltid. Du har ingenting å frykte. Det er ingenting du kan foreta deg som er galt.» Mange avfeier kjærlighetsbudskapet som tull fra New-Age-bevegelsen, og går dessverre glipp av den enorme sannheten, og dermed den helende kraften, ifølge Eben. (Nygaard, 2014) 


\section{Sammenligning, oppsummering, konklusjon}

Felles for de tre fortellingene er at subjektet eller hovedpersonen i utgangspunktet ønsker å unngå døden og det som kommer etter den. For Jack O'Lantern arter døden seg som mørke, kulde og ensomhet. På grunn av veddemålene han har inngått, får han ikke fellesskap med noen - verken i himmelen eller i helvete. Og selv om livet i helvete ikke varer evig for Mogallanas mor, straffes hun hardt og lenge - ikke av Gud eller djevelen eller noe annet mytologisk vesen, men av tilværelsens egen lovmessighet: karma. Begge fortellingene samsvarer mer eller mindre med formaliserte dogmer innenfor henholdsvis kristendom og buddhisme, mens Eben Alexanders fortelling og dens implisitte forestillinger om døden er vanskeligere å plassere. Fordi han opplevde «himmelen» mens han var i ferd med å $\mathrm{d} ø$, har han et mer positivt syn på døden enn de to andre. Alle tre ønsker behag, fellesskap og tilhørighet, men Jack får ikke noe av dette, og Mogallanas mor får det ikke før sanghaen tar affære.

Jack O'Lantern er et menneske som har innledet forhandlinger med mytologiske krefter i stedet for å godta livet og døden slik de er innrettet. Etter å ha «vunnet» to omganger og sluppet unna både døden og helvete, går han til sist i sin egen felle. Moralen i fortellingen synes å være at mennesket må godta sin plass og rolle som menneske og ikke agere guders likemann. Når Jack forhandler med sin motstander, blir hjelperen (Gud selv) en enda større motstander, og med begge to imot seg klarer han seg ikke.

Fortellingen om Mogallana foregår i et mytologisk univers, men uten mytologiske aktører. Her er det karmaloven som gjelder, og den er mer som en naturlov som alle bare må innrette seg etter. Selv om både Buddha og disiplene hans har overnaturlig innsikt og magiske evner, er de mennesker, og fortellingen viser hvor stor makt mennesker kan ha dersom de samhandler. Et menneskelig fellesskap kan ikke endre eller oppheve karmaloven, men det kan samarbeide med den. Munkene synes - i motsetning til aktørene i de to andre fortellingene - å være motivert av empati.

I fortellingen med kristen bakgrunn kjemper hovedpersonen en ensom og ujevn kamp mot både Gud og djevelen. Jack, som en gang var så handlekraftig, er i døden hengitt til vesener med mye større makt enn ham. Den 
buddhistiske fortellingen handler om empati og disiplin - ingen guder, bare mennesker som trumfer helvetesstraffen ved å overstyre karmaloven. Den siste fortellingen tilhører ikke noen gammel, etablert trostradisjon. Her er alt snudd på hodet: Døden er attraktiv, full av farger og lys, og det finnes ingen straff der «det er ingenting du kan foreta deg som er galt».

\section{Referanser}

Aagedal, Olaf (2010). Lystenning på graver som folkekyrkjeleg praksis. I Pål Ketil Botvar \& Ulla Schmidt (Red.), Religion i dagens Norge. Mellom sekularisering og sakralisering. Oslo: Universitetsforlaget.

Aagedal, Olaf (1996). Folkelege ritual. Religion og livssyn nr. 1.

Alexander, Eben (2013). Himmelen finnes. En nevrokirurgs fascinerende reise inn $i$ døden og tilbake. Oslo: Cappelen Damm.

Alpert, Richard, mfl. (1964). The Psychedelic Experience. A Manual Based on the Tibetan Book of the Dead. Ukjent utgivelsessted.

Blavatsky, Helena P. (1889). The Key to Theosophy. Hentet fra www.theosociety.org/ pasadena/key/key-6.htm (lest 02.08.2018).

Davies, Douglas J. (2002). Death, Ritual and Belief. 2. utg. London/New York: Continuum.

Eidhamar, Levi Geir (2017). Er straffen i helvetet rettferdig? Unge muslimers tanker om livet etter døden. I Ida Marie Høeg (Red.), Religion og ungdom. Oslo: Universitetsforlaget.

Garces-Foley, Kathleen (Red.) (2015). Death and Religion in a Changing World. New York: Routledge.

Gilhus, Ingvild, \& Mikaelsson, Lisbeth (Red.) (1998). Skjult visdom - universelt brorskap. Teosofi i Norge. Oslo: Emilia.

Gilhus, Ingvild, \& Mikaelsson, Lisbeth (2005). Kulturens refortrylling. Nyreligiøsitet $i$ moderne samfunn. 2. utg. Oslo: Universitetsforlaget.

Hébert, Louis (2006). The Actantial Model, Signo. Hentet fra www.signosemio.com/ greimas/actantial-model.asp (lest 29.10.2017).

Jack O'Lantern. Hentet fra https://www.aktivioslo.no/guide/halloween/jack-olantern/ (lest 05.03.2017).

Jacobsen, Knut A. (2003). Hinduismen. Oslo: Pax.

Jacobsen, Knut A. (Red.) (2011). Verdensreligioner i Norge. 3. utg. Oslo:

Universitetsforlaget.

Kalvig, Anne (2016). Spiritisme. Samtaler mellom levende og døde. Oslo: Pax.

Kværne, Per (200o). Den tibetanske dødeboken, buddhismen og Vesten.

I Henrik Mathisen (Overs.), Den tibetanske dødeboken. Oslo: Gyldendal.

Kværne. Per (Red.) (2005). Tibet. Oslo: Bokklubben. 
Mathisen, Henrik (Overs.) (200o). Den tibetanske dødeboken. Oslo: Gyldendal.

Moody, Raymond A. (1996) [1975]. Livet etter livet. Hva som skjer etter «døden»beskrevet av folk som ble erklort døde, men siden gjenopplivet. Oslo: Grøndahl Dreyer.

Neegaard, Gunnar (1993). Religion, livssyn og gravferd. En håndbok om gravskikker. Oslo: Kommuneforlaget.

Nygaard, Kai (2014). Eben Alexander: Himmelsk reise. Magasinet Visjon nr. 1/2014 Hentet fra magasinetvisjon.no/visjon/eben-alexander-himmelsk-reise/(lest 02.10.2017).

Ny verden-oversettelsen av De hellige skrifter (1996). New York: Watch Tower Bible and Tract Society of Pennsylvania. Hentet fra https://www.jw.org/no/ publikasjoner/bibelen/bi12/boker/ (lest 17.08.2017).

Oestigaard, Terje (2004). Death and World Religions. Human Responses to the Inevitable. Bergen: BRIC Press.

Smith, Jane Idleman, \& Haddad, Yvonne Yazbeck (2002). The Islamic Understanding of Death and Ressurection. Oxford/New York: Oxford University Press.

Winje, Geir (1999): Fra bønn til magi. Nye religioner og menneskesyn. Kristiansand: Høyskoleforlaget. 


\title{
KAPITTEL 5
}

\section{Steder for død. En vandring gjennom retorisk dødseulogi}

\author{
Iben Brinch Jørgensen \\ Universitetet i Sørøst-Norge
}

\begin{abstract}
Summary: Eulogy (from Greek eulogia) includes the act of speaking about (and sometimes to) dead people in epideictic, rhetorical genres and during ceremonial situations. In this article, the reader will be taken on a guided tour around the rhetorical practice of eulogy of death, not in general, but to highlight how places form and frame the rhetoric of death. During the tour, we go back to antique texts and walk along the line to modern rhetorical discourses. Plutarc's biographical texts show how the place where a person dies offers a symbolic meaning that can be used in the characterization of this person's virtues. The symbolic meaning of places of death has rhetorical power. The official funeral speeches in Athens use the polis as the central premise to accept war and loss of soldiers. To die for the nation is also a central theme in modern rhetoric. The rhetorical practices use specific places to frame the rites and rituals, and we build places to empower the places for remembering in a certain way. How death is valued has impact on architecture, landscapes and cities. These places become a part of our lives and frames the future eulogy of death.
\end{abstract}

Keywords: death, epideictic rhetoric, eulogy, place, rhetoric

\section{Introduksjon}

Huset ligger utsatt til på St. Helanas nordvestlige side. Lenge hadde det vært snakk om å bygge et annet hus til den prominente fangen. Et som lå mer beskyttet for vær og vind enn Longwood House. Men på sin dødsdag i mai 1821 var Napoleon Bonaparte fremdeles bevoktet der. Det ble hans sted å dø. Longwood lå ikke bare ytterst på ei øy, men øya lå langt ute i Sør-Atlanteren, hinsides det Frankrike som Napoleon både hadde kjempet for militært og vært keiser for. Ingen hustru var ved hans side slik at hun kunne ha holdt ham i hånden på dødsleiet. Det var nok ikke skjebnen som ville at Longwood ble Napoleons sted å dø. Det var snarere hans engelske fangevokter som forhalet flyttingen til et annet hus.

Sitering av denne artikkelen: Jørgensen, I. B. (2018). Steder for død. En vandring gjennom retorisk dødseulogi. I A. Johannessen, N. Askeland, I. B. Jørgensen \& J. Ulvestad (Red.), Døden i livet (Kap. 5, s. 87-102). Oslo: Cappelen Damm Akademisk. https://doi.org/10.23865/noasp.40.ch5

Lisens: CC BY-NC 4.0 
Kanskje vil noen si at stedet der Napoleon døde, var noe paradoksalt sett i relasjon til hans liv. Vurdert med retoriske briller fungerer Napoleons endelikt i fangenskap på ei fjern øy først og fremst som et argumentved å være et eksempel på hvordan stedet hvor døden skjer, spiller en rolle i den kollektive tolkningen av en persons karakter og betydningen av hans eller hennes liv. Sammen med dødsårsaken og tidspunktet for døden utgjør stedet en del av konklusjonen på argumentet om hva som var meningen med livet. Storhet og fall. Den lille korsikaneren som blir innhentet av sin faktiske størrelse.

I dette kapittelet forsøker jeg å fange retorikkens tematisering av steder for død med et stormasket nett. Målet er å komme nærmere en forståelse av hvordan stedet for død har blitt tillagt retorisk betydning. Jeg har selvfølgelig vært nødt til å fiske der jeg har hatt en forforståelse av at det er noe å hente, som i Plutarks sammenlignende biografier. Men jeg har også søkt mer bredt og fulgt strømmer gjennom kildematerialet fra de atenske begravelsesritualene og Platons dialoger, fra Lincolns åpning av gravlunden for falne soldater fra borgerkrigen til statsminister Stoltenbergs tale etter terrorhandlingen 22. juli 2011 i Norge - og videre til ulike steder hvor vi minnes våre døde.

Steder for død skal altså forstås ganske bredt: som stedet du faktisk faller om eller sovner inn, stedet du venter på å bli begravd, brent eller sendt ut på sjøen, stedet du finner den siste hvile, stedet du blir minnet, og stedet dine etterlatte forestiller seg at du har kommet til etter at du forlot dem. De retoriske sjangrene hvor stedet for død tematiseres, er likeledes lang: fra de verbalspråklige eulogiske sjangrene som nekrolog, epigram, begravelsestale, minnestund og biografi til de stedene som har en retorisk funksjon for å tematisere død, som gravplasser, kirkegårder, minneparker, kirker, templer og steder med minneplater. Vi har emblematiske skulpturer av engler og skjeletter som minner oss om at vi skal dø, og vi har gater, plasser og institusjoner som oppkalles etter døde personer. Retorikk, sted og død krysser hverandre på mange steder.

Innsamlingen av materialet er generert av en «topisk» tilnærming til det å søke. Dette innebærer en heuristisk metode innen retorikken der man leter etter stoff på ulike «topoi», altså «steder» (Andersen, 1995, s. 154). En topos er et sted på gresk, og en topisk metode betyr da å bevege seg rundt 
i bevissthetens og kulturens abstrakte - og for dette kapittelet altså også konkret fysiske - landskap for å hente stoff for ens tematiske tenkning og til ens egen retoriske fremstilling (Söderberg, 2017, s. 7; Togeby, 2009, s. 8). Underveis i letingen får man innblikk i kulturens måter å kategorisere og verdibestemme temaet og undertemaer på - man blir kjent med doxa (Rosengren, 2008). Samtidig vil man finne anvisninger om måter å fremstille temaene på i en retorisk diskurs, og dermed også få innblikk i argumentasjonsformer knyttet til temaet (Gabrielsen, 2008, s. 83).

\section{Doxa og død}

Noen av de topoi vi ser i spill når vi vurderer den retoriske betydningen $\mathrm{i}$ Napoleons død, er den geografiske avstanden mellom virkested og dødssted, den standsmessige kontrasten mellom de stedene han var på høyden av sitt liv og dødsstedet, det kvalitative og kvantitative forhold til andre mennesker - mellom hvilke og hvor mange mennesker som er rundt den døende, og hvordan han ellers har stått $\mathrm{i}$ livet når det gjelder relasjoner. Hertil kommer en endring i maktposisjon som stedet representerer. Slike topoi viser til de «stedene» av språklig, argumentatorisk og kulturell karakter som vi kan bruke retorisk. Disse ulike topoi, og særlig der det oppstår kontraster eller stor fallhøyde, byr på paradokser.

Nå spør du kanskje deg selv om hvor disse topoi kommer fra, og muligvis også om denne listen er uttømmende. Svaret på det siste er at listen selvfølgelig kunne vært både annerledes, kortere og lengre hvis en annen person hadde laget den. Den baserer seg på samme tid på kulturens felles topoi og på topoi som er spesifikke for dette forskerjeget og dette eksemplet. Skulle jeg ha tatt Napoleons eksempel videre og søkt etter flere topoi, måtte jeg ha tematisert resten av fortellingen om hans død. Han ble nemlig først begravd på St. Helena, men levningene hans ble 19 år senere - i 1840 - fraktet «hjem» og kjørt gjennom gatene i Paris, for året etter å få sitt siste hvilested i form av en storslått sarkofag i en krypt i bygningskomplekset Saint-Louis des Invalides. Slik sett snus den paradoksale historien til en historie om triumf og om storslåtte og symbolske nasjonale begravelesskikker. En praksis der den retoriske verdien ved Paris og et historisk bygg som steder brukes til fulle. 
Ved å undersøke og vurdere hvilke topoi som brukes om steder mennesker dør og begraves, får vi et grep om doxa, altså de bakenforliggende delte livsanskuelsene og verdensbildene vi kan trekke frem til heder eller diskusjon (Aristoteles, 2006; Rosengren, 2008; Söderberg, 2012). Det viktigste i en retorisk, doxologisk undersøkelse er nettopp å peke ut hvilke topoi som er innrammet, frontet og klynget sammen i betydningsenheter (Berry, 2012; Brinch Jørgensen, 2016; Burke, 1966). Ensartet og forskjellig bruk av topoi viser hegemonier og diskurskamper. Slik kan vi bruke en topoianalyse som inngang til både synkrone og diakrone analyser av doxa, og altså også i undersøkelsen av doxa knyttet til død. Det kan ikke gjøres fra en objektiv vinkel, men må gjøres i kraft av en fenomenologisk-hermeneutisk metode for å trosse og trekke på analytikerens livsverden og fordommer (Brinch Jørgensen, 2016; Dahlager \& Fredslund, 2011; Villadsen, 2009). Hadde vi i stedet brukt Goethes død som eksempel, hadde det vært andre topoi. Han døde i sin seng i sitt hjem i Weimar, i det landet han elsket, med sin lege ved sin side (der han ryktes å ha sagt «Mehr Licht!» som det siste). Det at han som romantiker passende døde av et hjerteinfarkt, må også tas med. Vi hadde da fått øye på toposen sammenheng mellom liv og død, noe som på forunderlig vis også kan bli ironisk, særlig for den som ser ironien i klisjeen.

\section{Ord mot døden}

«Mer lys.» Viktigheten av de eksakte ordene som blir sagt før døden inntreffer, er ikke til å spøke med. Goethes liv og lære stod til en lys og ikke en nihilistisk avslutning. Han skulle til et opphøyet sted, ikke til et ikkested. Ordene får en alvorsfull tyngde når noen er $\mathrm{d} ø \mathrm{~d}$, noen begraves og noen minnes. Metaforene brukes flittig for å beskrive kampen mot kreften og de følelsesmessige brytetakene når man mister en far, en ektefelle, et barn. Bruken av ord ved død er «ord mot døden», «words against death», slik religionsviter Douglas Davies beskriver dødens retorikk i boken Death, Ritual and Belief. The Rhetoric of Funerary Rites (Davies, 2002): «Words against death need to be spoken, and they can be secular words just as they may be religious words» (s. 215). 
Ordet «mot» kan virke krigerisk. Men det er slik Davies ordlegger seg. Imidlertid ser det ut til at han mener at ordene er redskaper $i$ en eksistensiell prosess snarere enn blott til forsvar, og at vi er dødelige, selvbevisste skapninger som bruker språket som vårt primære medium i selvbevissthetens kontinuerlige tilblivelse (Davies, 2002, s. 1). Her kommer betydningen av stedet inn: «funerary rites frame this verbal response, relating it to other behavioural features of music, movement, place, myth and history» (min kursivering; Davies 2002, s. 2). Ordene innrammet av ritualer og satt i forbindelse med blant annet stedet, er det som blir eksistensens forsvar mot døden. Dette forsvaret har ikke bare en kognitiv funksjon, men gjør mennesket som skapning bedre skikket til å leve: "human beings are transformed in ways which make them better adapted for their own and for their society's survival in the world» (Davies, 2002, s. 2).

Stedet bidrar til å innramme døden i alle dens stadier: fra den døende, til den «våte» og nettopp avdøde kroppen og til den «tørre» kroppen i form av bein, aske eller mumie (Robert Hertz' teori gjengitt hos Davies, 2000). Vi har å gjøre med to sett med riter knyttet til de to fasene i form av den våte og den tørre død, og de ritene tar seg ulikt ut i ulike kulturer og opp gjennom historien. Napoleons «siste sted» ble fortalt to ganger med to ulike riter og to ulike utfall - der narrativet og meningen med eksemplet er forskjellig. Vi har steder til å begrave levningene eller plassere eller spre aske, og vi har steder til å holde taler for de døde, sette opp minnesmerker, lage parker, plasser og gater med de dødes navn. Hertil kommer den ikke ubetydelige abstrakte og religiøse forestillingen om hvilket sted den døde kommer til etter døden, som vi også minner oss selv om gjennom ord og ritualer, men også på steder ved å plassere ulike kulturelle og kunstneriske artefakter der som skal minne oss om Døden, transendens, stedene for etterlivet samt forfedrene.

Et underliggende premiss hos Davies er at individet faktisk tilhører et fellesskap som deler et språk mot døden. All profesjonalisering, institusjonalisering og standardisering av hvordan vi håndterer døende, døde og minnesmerker i ord og ritualer, bidrar til å flytte dødens eksistensielle utfordring for den enkeltes selvbevissthet til fellesskapets kollektive bevissthet (Davies, 2002, s. 17). Det er derfor at det er i praktiseringen av 
tradisjonen (diskurs og rituell praksis) og i offentlighetens diskusjoner av endringer av tradisjonen at vi finner ut mer om doxa. Det er i skapingen, reproduksjonen og utviklingen av retoriske sjangrer knyttet til dødsritualer at vi finner retorikkens bidrag til fellesskapets håndtering og forsvar mot døden. Her blir det tydelig at forsvaret mot døden ligger i kulturelle og språklige fellesskap, og at individer i et urbanisert, kosmopolitisk og mer eller mindre sekularisert samfunn kan stille ganske svakt overfor tap i hjemmets sfære (Davies, 2002, s. 17). Det kan tenkes at etableringen av sjangrer som bloggtekster om individers håndtering av død og tap tilhører denne individualiserte kulturens «ord mot døden». I tillegg kan det forklare hvordan taushet eller spontan retorikk kan bli rett retorisk respons på rett sted, og hvorfor stedet i seg selv ikke markeres som betydningsfullt for fellesskapet, men bare for de etterlatte.

Davies skriver om en britisk nåtidig virkelighet der det å spre aske er langt fra en kristen symbolsk forståelse av asken som symbol på den avdøde kroppen. Han skriver at det å spre asken på et valgfritt sted snarere er en «this-worldly fulfillment of life through human relationships, rewarding work and lesisure» (Davies, 2002, s. 141). Hvis for eksempel en partner dør, kan den etterlatte velge å spre asken på et sted i naturen hvor de to har hatt det fint sammen. Stedet for død blir da av personlig og relasjonell betydning. Videre forklarer Davies at handlingen krever få ord, at folk faktisk ofte sprer aksen i taushet eller fulgt av spontant fremførte setninger eller planlagte strofer fra en sang eller et dikt (Davies, 2002, s. 141). Dette er langt fra den offentlige gravtalen, og har en helt annen retorisk funksjon. Videre skriver Davies at den lokaliseringen som er valgt for askespredning, sjelden minnes på konkrete måter med inskripsjoner eller lignende, og slik sett heller ikke bidrar til å plassere døden i våre delte omgivelser. Kanskje man kan tilføye at stedet blir viktig i kraft av sin egenskap av natur fremfor kultur, og at denne måten å bruke stedet på viser at også naturen kan brukes retorisk.

Samtidig har publikum til en slik askespredning en helt annen status enn publikum på en offentlig minnesmarkering av døde soldater eller ofre for en terrorhandling. 


\section{Døden finner sitt publikum}

Ved å se på hvem som lar seg fortelle en livs- og dødshistorie, får vi øye på oss selv og hverandre som retorisk publikum (Bitzer, 1997[1968]). Å la seg tiltale betyr i retorisk - så vel som i hermeneutisk - forstand at vi har en forforståelse av temaet og dets kulturelle betydninger som vi utfordrer. Vi stiller oss åpne for å forstå bedre eller på en ny måte, dvs. flytte oss fra vår forforståelse, enten det er en bekreftelse på den eller en endring av den. Når vi stiller oss åpne for å forstå, er vi et publikum for andres diskurs og argumentasjon. Den som ønsker å overbevise eller overtale, kalles med en referanse til den klassiske retorikken for taleren, selv om det i moderne retorikk like fullt kan være snakk om skribenten. Sett fra talerens synsvinkel er publikum dem han eller hun ønsker å nå med sitt budskap, en slags visualisert og innbakt konstruksjon i den retoriske diskursen (Perelman \& Olbrechts-Tyteca, 2010[1969], s. 19). Publikum er da å forstå som den mottaker som taleren eller avsenderen skriver inn i sin fortelling på den ene siden, og den rollen vi går inn i som publikum når vi lar oss tiltale, på den andre. Det siste er et viktig poeng, for det gjør at også publikum blir tildelt et etisk ansvar for hvordan det lar seg tiltale.

Som retorisk publikum må vi vurdere hva den retoriske praksisen og eulogien gjør med oss som individer og som fellesskap. Er det først og fremst vår individuelle forforståelse og identitet som utfordres? Eller er det doxa og kollektivets selvforstålse? Vi er publikum til den retoriske diskursen der steder for død tematiseres, og vi er publikum $p a ̊$ steder - in situ - hvor død tematiseres og innrammes av ulike artefakter og arkitektoniske miljøer. Stedene for død tilfører - sammen med mennesker og ting - «a framework of significance to our lives» (min kursivering; Davies, 2002, s. 13).

\section{Retoriske dødssjangrer}

Når det gjelder retoriske ytringer etter et menneskes død, er det først og fremst begravelsestalen (epitaphioi) som må trekkes frem som en viktig sjanger med dens dype røtter i antikken og tette forbindelser til 
utviklingen av selve det atenske demokratiet (Loraux, 2006). Av begravelsestalen springer også flere skriftlige sjangrer frem - som nekrologen og ulike former for minneord fremsagt i mer litterær form som dikt eller i brevform, med den latinske betegnelsen consolatio. Slike minneord kan spores tilbake til den romerske retoriske tradisjonen, særlig hos Cicero og hos renessansens humanister. Vi har også epigrammet, som fant sitt publikum - særlig fra opplysningstiden og fremover - gjennom en bredere offentlighetskultur. I tillegg til disse sjangrene som hører direkte til vår vestlige kulturs «ord mot døden», kan vi også snakke om eulogisk retorikk og det å eulogisere som talehandlinger i andre sjangrer. Eulogiske trekk finner vi i særlig grad i moralske tekster, i biografien, i selvbiografien og i episke fortellinger. Eulogisering av menneskers død tydeliggjør at det finnes et siste sted for døden: Minnet. Dette er et sted som eksisterer så lenge mennesker ivaretar muntlige og skriftlige kilder. Hvis minnet dør, er døden endelig. I hvert fall blant de levende.

\section{Døden som dydens eksempel}

Paradoksale steder å dø på, enten det er i sakprosaen eller i skjønnlitteraturen, fungerer som sensasjonelle, spektakulære eller fortettede eksempler på hvordan et liv kan og bør leves. Og hvordan det kan eller bør avsluttes. Et eksempel kan skape grunnlaget for generalisering, det kan tjene som en illustrasjon på en allerede etablert kultur eller vedtatt sannhet, eller det kan oppmuntre til etterfølgelse (Gabrielsen, 2008; Perelman \& Olbrechts-Tyteca, 2010[1969], s. 350). I antikken var man opptatt av hva kjente personer - mytiske, litterære og etter hvert også historiske - kunne gi av lærdom i kraft av sitt eksempel. Det såkalte «emulasjonsprinsippet» besto $i$ at beskrivelsen av gode karaktertrekk og handlinger hos den skildrede ville inspirere publikum (Egeland, 20o1, s. 38 og 53).

Plutark (ca. 46-120 e.Kr) skrev i det første århundre en rekke sammenlignende biorafiske tekster, Bioi Paralleloi (Plutarch, 2004 [1892-99]; Russell, 1966, 1982). Tekstene er bygget opp slik at en greker og en romer skildres parvis - først hver for seg og så i en sammenligning. I disse tekstene finner vi kimen til en biografisk fremstilling med vekt på en persons virke, fysiske trekk, dyder og handlinger. I enkelte av biografiene ser vi de 
klassiske dydene diskutert opp mot dødsårsak og stedet for døden, begravelsen og hvordan den skildrede blir minnet (Plutarch, 2004 [1892-99]). Måten noen døde på, kan hos Plutark ikke skilles fra stedet det skjedde på. Dødsårsaken, dødsstedet og stedet for begravelse blir diskutert særlig inngående i den parallelle skildringen av Pelopidas og Marcellus (Plutarch, 2004 [1892-99]. Del II). Måten disse to døde på, hadde tilsynelatende mange fellestrekk, men nyansene var viktige for å forstå om de var gode eller mindre gode eksempler på homo virtus.

Både Pelopidas og Marcellus var hærførere som ble drept i krig på fremmed jord, men Plutark er likevel ikke overbevist om at deres død stod i forhold til deres liv. Pelopidas kunne bli unnskyldt fordi han var oppspilt i løpet av slaget, og at det var hans modige karakter som drev ham frem mot fienden i et forsøk på å ta fiendens leder og oppnå den høyeste ære. Hans død var ingen ulykke, «but a premeditated act» (Plutarch, 2004 [1892-99], s. 64, Vol. II, del 66). Like fullt er dette bare det nest beste for en slik general; det beste er å seire og overleve. Marcellus, derimot, kastet seg «hodeløst» inn i farene og døde «spionens død» snarere enn døden til en hedret general. Han satte alle sine æresbevisninger og fem konsulutnevnelser over styr imot de «verdiløse livene» til sine fiender: «They themselves must have felt ashamed at their success, that the bravest, most powerful, and most celebrated of the Romans should have fallen among a reconnoitring party of Fregellans» (Plutarch, 2004 [1892-99], s. 64, Vol. II, del 66).

Plutark diskuterer heretter om de to fikk den begravelsen som passet seg for deres karakter og handlinger. Både Pelopidas og Marcellus ble begravd borte fra hjemstedet av andre enn sine egne. Men her blir det sett på som bedre å bli begravd respektfullt av sine fiender, slik Marcellus gjorde, enn av sine allierte, slik tilfellet var for Pelopidas: «[A]s the spectacle of an enemy honouring the valour by which he has suffered is greater than that of a friend showing gratitude to a friend», og videre: «In the one case it is the man's glory alone that is respected, in the other, his usefulness and value are as much thought of as his courage» (Plutarch, 2004 [1892-99], s. 64, Vol. II).

Den sammenlignende biografien, slik Plutark skriver den, er et moralsk lærestykke der argumentasjonen i seg selv blir utslagsgivende for 
hvordan en persons minne blir kanonisert i kulturen. Tekstene hans har hatt en omfattende virkningshistorie for utviklingen av retoriske tekster, slik som essayet hos Montaigne og vår egen Holberg. Utviklingen av selve biografien som en litterær sakprosasjanger som ikke primært er opptatt av historisk korrekthet og beskrivelsen av begivenheter, men vel så mye av scenisk underholdning og diskusjon av karakterutvikling, står også i gjeld til Plutark (Egeland, 2001). Biografisjangeren i sin tradisjonelle drakt, der den biograferte følges fra vugge til grav, er et utbygget eksempel på et levd liv (Caine, 2010). Ofte er den biografiske teksten i seg selv av litterær kvalitet, og dermed en epideiktisk sjanger, og vi blir også kjent med den biograferende forfatterens selv (Egeland, 2000, 2001). Dette inkluderer biografens forhold til betydningen av død og steder for død.

Stedet for døden kan brukes i eulogiske tekster for å styrke sammenhengene hos en karakter eller underbygge kontraster. Steder har altså en verdi å låne bort til den døde - deres egen «stedets retorikk» (Brinch Jørgensen, 2016, s. 30). Samtidig trenger døden en taler eller en tekstforfatter, altså en biograf som kan formulere en passende eulogi for å sette stedets retorikk inn i konteksten. Fravoret av å nevne stedet for avslutningen har empirisk verdi for den forskeren som ønsker å kartlegge sammenhengen mellom sted og død.

\section{Å dø for polis og fellesskapets bestående}

Også tidligere tekster enn Plutarks tematiserer døden retorisk. Den klassiske greske historikeren Thukydid (460/455-40o f.Kr.) skrev om Peloponneserkrigen - krigen mellom Athen og Sparta som vartei 27 år (Thucydides, 1999). I hans verk gjengis en tale holdt av Perikles, som var både hærfører og statsmann (Thucydides, 1999, bok 2, avsnitt 34-46). Perikles fikk det ærefulle vervet å holde den årlige talen for de falne atenere ved den felles statsbegravelsen, en ære som var få forunt (Loraux, 2006).

Perikles gjør i den gjengitte talen mye ut av å beskrive Athen som det stedet, den byen og den polis som de falne kommer fra og har kjempet for med livet som innsats. Her blir Athen som sted den motvekten som skal rettferdiggjøre tapet av de unge mennenes liv. Athen er saken som man kjemper og dør for: «Deres [i.e. de falnes] død synes meg å vitne om deres 
tapperhet, enten nå døden var den første som meldte om den eller den satte kronen på verket. Har noen av dem vært ikke fullt så bra i andre forhold, er det riktig å fremheve deres tapperhet overfor fienden til forsvar for fedrelandet» (Thucydides, 1999, s. 117). Nicole Loraux skriver i The Invention of Athens. The Funeral Oration in the Classical City om hvordan begravelsestalen var en «institusjon», hvor det symbolske hele tiden økte det funksjonelle ved talen, nemlig å skape generalisert lovprisning av Athen (Loraux, 2006, s. 27). Likevel var ikke talen bare en epideiktisk tale for å underholde og understreke fellesskapet. Den var bygget på en demokratisk topos, hvor innbyggerne valgte sin mann til å tale for sine falne og for polis. Begravelsestalen var på denne måten en direkte ytring om det unike ved Athen som demokrati, samtidig som institusjonen "gravtale for de falne» var en gjennomspilling av grunntanken ved det atenske, aristokratiske demokratiet (Loraux, 2006, s. 39).

Talen til Perikles ble en mønstertale for begravelsestalen, og angir dermed at nettopp en lang lovprisning av det stedet soldatene kjemper for, er nødvendig, ikke bare som rettferdiggjørelse av tapene, men også som en styrkelse av tilhørernes fellesskapsfølelse og ønske om å støtte fremtidige kriger. Det var likevel ikke selve byen - med dens agora, hus, jorder og utmark - som var polis. Athen kunne forlates og likevel bestå. Det var den delte idéen om Athen som var polis. Denne måten å tenke på et sted på, gå i krig for det og lovprise det i begravelsestaler har blitt brukt videre i det vestlige begrepet om nasjonen frem til i dag. På den måten inneholder moderne retorikk i forbindelse med krig og terror lignende trekk der saken i form av fellesskapet som et sted kalt nasjon, er fremtredende. Likevel har talen til Perikles hos Thukydid en vri som knapt er å finne i moderne nasjonsbundne minnetaler for falne soldater eller ofre for terror, nemlig at «fremragende menn har hele jorden som sin grav»: «[D]en herligste grav, ikke den som deres legemer hviler i, men den hvor deres ry lever evig så lenge som en tale eller en handling vil gi anledning til å minnes dem» (Thucydides, 1999, s. 118).

Ifølge Øivind Andersen finnes det fem bevarte antikke greske begravelsestaler som deler mange av de samme topoi, og som også har den minimale referansen til religion til felles (Andersen, 2003). Med Platons tekst Menexenos finner vi en begravelsestale som Platon lar Sokrates fremføre 
som en hermende pastisj over sjangeren (Plato \& Andersen, 2006). Teksten har fungert som en modell for senere eulogiske tekster - på samme måte som talen til Perikles hos Thukydid. Andersen har skrevet innledningen til Menexenos i den norske utgaven fra 2006. Her står det at teksten ikke skal ses som en alvorlig ment modelltekst og et grunnlag for innblikk i doxa, men at den like fullt «inneholder (iallfall implisitt) politisk refleksjon og politiske anbefalinger», noe som gjør den deliberativ og «også er til å bli klok av» (Plato \& Andersen, 2006, s. 326). Gravtalen kan leses som en parodi på den retoriske sjangeren gravtale, men den er imidlertid for sjangertro til at den fungerer bare som parodi. Den inneholder nemlig de fleste av de topoi man finner i de andre gravtalene.

Gravtalen består av en innledning der talen settes inn i sin kulturelle kontekst og henviser til gjengse ritualer og tradisjoner rundt død. Innledningen gir også en oversikt over hva som kommer i talen, som er en lovprisning av de døde, herunder deres avstamning, oppvekst og ikke minst deres dyder. Lovprisningen av de falnes dyder knyttet til kamper og kriger fyller mest i talen. Heretter følger en oppmuntring og trøst til de etterlatte i form av en tale fra de falne til deres sønner og foreldre. Her bruker Platon en særlig retorisk figur, nemlig eidolopoiia, der de døde taler fra den andre siden. Vi kjenner den igjen i mange fiktive karakterers møte med døde, for eksempel i scenen der Gjenferdet viser seg for Hamlet på skansen på Kronborg og kaller seg «din faders ånd». En slik figur vitner om at det finnes en allmenn aksept i kulturen for at det er et sted etter døden, der den døde «kan komme tilbake fra» eller kommunisere til de levende fra et annet sted.

Talen til Platon avsluttes med et avsnitt som beskriver hvordan byen skal minnes sine døde: «De falne selv holder byen aldri opp å ære. Én gang årlig utfører den felles for alle de ritualene som ellers gjøres privat for hver især. I tillegg arrangerer den tevlinger i gymnastikk og hestesport og all slags musisk kunst» (Plato \& Andersen, 2006, s. 345). Byen skal som helhet brukes til å innramme minnestunder. På et vis gjøres selve byens rom og bylivet til møteplasser mellom levende og døde, og transenderer avstanden mellom liv og død: «For de avdøde står byen $\mathrm{i}$ arvingens og sønnens sted, for sønnene i farens sted og for de falnes foreldre i en forvalters sted: Den har full omsorg for alle alltid» (Plato \& Andersen, 2006, s. 345). 
Retorikken i de her nevnte klassiske gravtalene har gjennom historien spilt en stor rolle ved begravelser og innvielser av minnesmerker. På denne måten har de klassiske tekstene hatt betydning i utviklingen av en retorisk praksis. Et sentralt eksempel på noe som minner om den klassiske gravtalen, er talen som den amerikanske presidenten Abraham Lincoln holdt i november 1883 for de falne soldatene i den amerikanske borgerkrigen, den såkalte Gettysburg Address. Talen ble holdt på Soldiers’ National Cemetery i Gettysburg i staten Pennsylvania. Den er blitt Lincolns mest berømte tale, kanskje fordi den knytter de falne soldatene så tett sammen med nasjonen som et sted basert på en idé om frihet og demokrati. Talen fungerer langt på vei som den atenske gravtale - til å hedre og forene:

It is rather for us to be here dedicated to the great task remaining before usthat from these honored dead we take increased devotion to that cause for which they gave the last full measure of devotion - that we here highly resolve that these dead shall not have died in vain - that this nation, under God, shall have a new birth of freedom - and that government of the people, by the people, for the people, shall not perish from the earth. (Lincoln 1883/1884)

Den korte talen er gjengitt på tavler og satt opp på et minnesmerke på gravplassen for de falne, og har på denne måten blitt til en del av stedet. I forhold til den greske begravelsestalen spiller religion en stor rolle hos Lincoln.

Ved minnemarkeringen av ofrene for terroren 22. juli 2011 i Regjeringskvartalet og på Utøya holdt daværende statsminister Jens Stoltenberg en tale som bygger på en lignende sammenstilling av topoi, der døden gis mening som en markering av nasjonens verdier: «I fellesskap knytter vi en ubrytelig lenke av omsorg, demokrati og trygghet. Det er vårt vern mot vold» (Stoltenberg, 2011). Den spontane handlingen der folk i Oslos gater legger ned roser og holder roser i hendene under de offentlige talene, kan ses på som en sterk markering av at publikum lar seg tiltale. Publikum tok på seg et etisk ansvar som deltakere i den retoriske responsen på den utfordringen som ofrenes død representerte.

\section{Steder for dødsrefleksjon}

Roser på gaten. En hilsen skrevet til de døde festet til en bamse. Slike symbolske ytringer er en sentral del av den retoriske responsen på død. 
De etterlatte taler på et vis på tvers av liv og død til den døde - på vegne av seg selv eller fellesskapet. Slike retoriske praksiser viser samtidig en spontan bruk av stedet, og at den eksakte lokaliseringen av noens død har betydning. Vi har innrettet vårt kulturelle landskap og våre byer med fysiske steder som er ment å reflektere over død. Steder som er viet til dette, er kirker, kirkegårder, gravplasser og minneparker, selvfølgelig, eller steder i større parker med statuer og minneplater over falne. Man kan også nærmest falle over slike steder som er ment for dødsrefleksjon når man plutselig ser minneplater på fortauet utenfor ulike byhus til minne om deporterte jøder. Alt dette er minnesteder, måter å innramme refleksjonen over død, Døden og de døde selv på. At vi fortsatt ikke vet hva vi skal gjøre med Utøya og Regjeringskvartalet, forteller om divergens i doxa.

Forestillingene om livet etter døden har preget og preger fremdeles kulturlandskapet i stor grad. Jeg trenger ikke å nevne våre forhistoriske gravhauger eller gravplasser - eller pyramidene ved Giza, for den saks skyld. Davies kaller disse stedene «building against death» i stedet for «words against death» (Davies, 2002, s. 207). I renessansen bygget man parker som hadde emblematiske elementer i form av symbolske skulpturer og printede aforismer for å moralisere og for å minne om dyder og religion (Heiberg, 2016, s. 202-203). Døden som skjelett, kranium og som mannen med ljåen er en gjenganger i rennessansens motivkrets. Fremstillingen av Skjærsilden, Helvete og Himmelen går også igjen. Latinske aforismer som «memento mori» var en viktig del av renessansens emblematikk. Inngravert, innskrevet og innprentet på steder for dødsrefleksjon.

\section{Avslutning}

Steder for dødsrefleksjon skapes altså spontant. De markeres eller bygges på steder der folk faktisk døde, de skapes på steder ment for dødsrefleksjon, eller de etableres på steder der naturen bidrar til en stemning av fordypelse. Ofte markeres stedet med kjent symbolikk fra kulturens forestillinger om død. Steder tas også i bruk ved fremføringen av eulogier og brukes dermed retorisk for den verdien de tilfører. Retorikken har bidratt med topoi - måter å argumentere på, sjangrer og retorisk praksis, herunder bruk av 
stedet - til vår kulturs måter å møte døden på. Men det er også andre steder som på mer tilfeldig vis kan bli steder for død og dødsrefleksjon. For eksempel bordet hjemme, der jeg - som Finn Carling en gang før jeg ble født - avslutter skrivingen om død med ordene: "Allikevel, uansett hvor langt vi kommer i vår søken, vil vår bevissthet bare nå frem til en del av sannheten. Resten vil alltid forbli i taushet» (Carling, 1973, s. 159).

\section{Referanser}

Andersen, Øivind (1995). I retorikkens hage. Oslo: Universitetsforlaget.

Andersen, Øivind (2003). Æres den som æres bør: Et sjangertrekk i greske gravtaler. I Jon W. Iddeng (Red.), Antikke samfunn i krig og fred. Festskrift til Johan Henrik Schreiner (s. 76-86). Oslo: Novus Forlag.

Aristoteles (2006). Retorikk (Tormod Eide, Overset.). Oslo: Vidarforlaget.

Berry, Philippa (2012). Shakespeare's Feminine Endings: Disfiguring Death in the Tragedies. London: Taylor and Francis.

Bitzer, Lloyd. F. (1997[1968]). Den retoriske situation. Rhetorica Scandinavica, 3, 9-17.

Burke, Kenneth (1966). Language as Symbolic Action: Essays on Life, Literature, and Method. Berkeley: University of California Press.

Caine, Barbara (2010). Biography and History. Basingstoke: Palgrave Macmillan.

Carling, Finn (1973). Resten er taushet: Skisser om døden. Oslo: Gyldendal Norsk Forlag.

Dahlager, Lisa, \& Fredslund, Hanne (2011). Hermeneutisk analyse - forståelse og forforståelse. I Signild Vallgårda \& Lena Koch (Red.), Forskningsmetoder $i$ folkesundhedsvidenskab (4. utg.). København: Munksgaard.

Davies, Douglas (200o). Robert Hertz: The Social Triumph over Death. Mortality, 5(1), 97.

Davies, Douglas (2002). Death, Ritual and Belief: The Rhetoric of Funerary Rites (2. utg.). London: Continuum.

Egeland, Marianne (200o). Hvem bestemmer over livet? Biografien som historisk og littercer genre. Oslo: Universitetsforlaget.

Egeland, Marianne (2001). Biografiens retorikk (ph.d.-avhandling). Oslo: Universitetet i Oslo.

Gabrielsen, Jonas (2008). Topik, ekskursioner i den retoriske toposlore. Birkerød: Retorikforlaget.

Heiberg, Steffen (2016). Nye horisonter: Europas kulturhistorie i renossancen. København: Gads Forlag.

Jørgensen, Iben Brinch (2016). Når steder skapes: Fire studier av stedsutviklingens visuelle retorikk (ph.d.-avhandling). Oslo: Universitetet i Oslo. 
Lincoln, Abraham (1883/1884). The Gettysburg Address. Hentet fra http://rmc. library.cornell.edu/gettysburg/good_cause/transcript.htm

Loraux, Nicole (2006). The Invention of Athens: The Funeral Oration in the Classical City (2. utg.). New York: Zone Books.

Perelman, Chaïm \& Olbrechts-Tyteca, Lucie (2010[1969]). The New Rhetoric: A Treatise on Argumentation. Notre Dame, Ind.: University of Notre Dame Press.

Plato \& Andersen, Øivind (2006). Samlede verker: Hippias minor; Hippias maior; Euthydemos; Gorgias; Menon; Menexenos (Vol. B. 3). Oslo: Vidarforlagets kulturbibliotek.

Plutarch (2004 [1892-99]). Plutarch's Lives. Vol 1-4. A. Stewart \& G. Long (Red.), Hentet fra https://www.gutenberg.org/ebooks/search/?query=plutarch

Rosengren, Mats (2008). Doxologi: En essä om kunskap. Åstorp: Retorikförlaget. Russell, Donald A. (1966). On Reading Plutarch's Lives. Greece \& Rome, 13(2), 139-154. https://doi.org/10.1017/Soo1738350001545X

Russell, Donald A. (1982). Plutarch and the Antique Hero. The Yearbook of English Studies, 12, 24-34. https://doi.org/10.2307/3507396

Stoltenberg, Jens (2011). Tale ved nasjonal minnemarkering for 22.7.2011 i Oslo Spektrum, 21. august 2011. Hentet fra https://www.nrk.no/norge/statsministerenstale-1.7758132https://www.regjeringen.no

Söderberg, Maria Wolrath (2012). Topos som meningsskapare. Retorikens topiska perspektiv på tänkande og lärande genom argumentation. Ödåkra: Retorikförlaget.

Söderberg, Maria Wolrath (2017). Aristoteles retoriska toposlära: En verktygsrepertoar för fronesis. Hentet fra http://urn.kb.se/resolve?urn=urn:nbn:se:sh:diva-33305

Thucydides (1999). Peloponneserkrigen (H. Mørland (Red.) Vol. 1). Oslo: Aschehoug i samarbeid med Fondet for Thorleif Dahls kulturbibliotek og Det Norske Akademi for Språk og Litteratur.

Togeby, Ole (2009). «Steder» i bevidsthedens landskab - grene på idéernes tro: Om at finde stof til belysning af en sag. Aarhus: Aarhus Universitetsforlag.

Villadsen, Lisa S. (2009). Fortolkningens rolle i retorisk kritik. I Hanne Roer \& Marie L. Klujeff (Red.), Retorikkens aktualitet. Grundbog i retorisk kritik (s. 39-59). København: Hans Reitzels Forlag. 


\title{
Død i mors liv. Endringar i handtering og markering av dødfødslar i Noreg
}

\section{Ellen Kristvik}

Akershus universitetssykehus

\begin{abstract}
Summary: This paper addresses the change that has happened in the understanding, attitude and handling of stillbirths in Norway. Until a few decades ago, children who died at the very onset of life were not recognized as a cause for mourning. Parents seldom saw their children if they were born dead or expected to die soon afterwards. Today, parents who lose their child in stillbirth are encouraged to see and touch the child, and supported in facing and processing the loss. Still, there are many bereaved parents who have experienced a loss that was never acknowledged, without knowing what happened to the child they lost. With reference to the concept of closure in gestalt psychology, this paper discusses how ritual practices can contribute to a healing process. The discussion draws on material from an ongoing research project. The paper illustrates how inventive rituals can promote a reconciliation with an unrecognized loss, even if this take place long after the event.
\end{abstract}

Keywords: bereavement support, Norway, rituals, stillbirth

\section{Innleiing}

Litt vest for kapellet på Stalsberghagen gravlund står ei steinblokk i lys granitt. Steinen har form som eit tilhogd rektangel, litt lenger i breidda enn i høgda, og på venstre side er det bora eit hol tvers gjennom granitten. Framfor denne steinen er der stadig tente lys og friske blomstrar. Ein benk gir høve til å ta ein pause, for eit kort pusterom eller så lenge som ein kjenner for.

Ulikt andre minnesmerke på Stalsberghagen er det inga grav på nett denne staden. Den gjennombora granittsteinen er sett opp til minne om dei mange som rett nok ligg på denne gravlunden, men som er

Sitering av denne artikkelen: Kristvik, E. (2018). Død i mors liv. Endringar i handtering og markering av dødfødslar i Noreg. I A. Johannessen, N. Askeland, I. B. Jørgensen \& J. Ulvestad (Red.), Døden i livet (Kap. 6, s. 103-118). Oslo: Cappelen Damm Akademisk. https://doi.org/10.23865/noasp.40.ch6

Lisens: CC BY-NC 4.0 
gravlagde i løynd, som anonyme blindpassasjerar i andre sine graver. Dette handlar om dei som døydde før dei vart fødde, noko som var eit ikkje-tema inntil nyleg. Anonym gravlegging av dødfødde i framande graver var vanleg praksis fram til 1990-talet, då det vart slått fast at alle, uansett alder, har rett til ei eiga grav (Kultur- og kirkedepartementet, 2006). Steinen på Stalsberghagen kom etter press (Romerikes Blad, 2009).

Minnesmerket på Stalsberghagen har fleire parallellar. Steinar og skulpturar av ulik utforming er å finne på ulike gravstader i Noreg. I likskap med den gjennombora granittsteinen på Stalsberghagen er nokre av desse reine påminningar om dei anonymt gravlagde andre stader på kyrkjegarden. Andre stader markerer dei også eit område for nye graver, men der dei dødfødde blir lagt etter ønske frå dei etterlatne foreldra. Liknande minnesmerke er no å finne i mange andre land, som også har hatt ein praksis som svarar til den norske (Peelen, 2009; Walter, 1999 Wretmark, 1993).

Kva betyr det å ha fått desse minnesmerka? Noko av det dei representerer, er viljen til å ta oppgjer med tidlegare praksis og synleggjere det som lenge gjekk føre seg i løynd. Det eg spesielt vil fokusere på i dette kapittelet er korleis desse markeringane også kan inngå i eit sorg- og forsoningsarbeid for dei som har mista barn før fødselen, i ei tid der død i mors liv vart forteia og underslått. Å nærme seg det spørsmålet krev ei forståing av sorg og sorgarbeid. Eg byrjar derfor med å skissere nokre av dei tilnærmingane som har gjort seg gjeldande, og det perspektivet eg sjølv bygger på.

Kapittelet bygger til dels på mitt eige arbeid om avskjedsmarkering, sorg og sorgarbeid i tilknyting til tapet av barn i dødfødsel. Kjeldematerialet til prosjektet Parting with children who die before being known. Perspectives of bereaved parents and health care professionals on challenges connected to prenatal loss omfattar observasjon frå ulike former for minnemarkeringar, og intervju med etterlatne foreldre, jordmødre og sjukehusprestar. Feltarbeidet går framleis føre seg når dette kapittelet blir ferdigstilt. Etterlatne foreldre etter 26 dødfødslar er då med i prosjektet. Informantane er rekrutterte frå tre sjukehus, over ein periode på to år. 


\section{Om sorg og sorgarbeid, uferdig erfaring og det å lukke ein gestalt}

Synet på sorg og sorgarbeid har endra seg over tid. Pioneren Sigmund Freud trekte tidleg eit skilje mellom sorg som ein normal og naturleg reaksjon på eit tap, og den meir kompliserte og diffuse tilstanden han kalla melankoli (1917). Freud var også den som introduserte tanken om sorgarbeid. Dette såg han som ein nødvendig lausrivingsprosess; ein prosess som innebar eit brot med banda som knytte ein til det som var tapt, og gjorde det mogleg å skape nye tilknytingar i staden. Freuds arbeid om sorg og sorgarbeid står framleis som ein grunnleggande referanse på feltet, og deler av det har blitt vidareutvikla i ettertid. Men det er også eit arbeid som har blitt kraftig imøtegått. Medan Freud såg brot med emosjonelle band som avgjerande for ein god prosess, er det i dag erkjent og akseptert at relasjonen ikkje treng å gå tapt sjølv om eit kjært menneske døyr, og innhaldet i eit sorgarbeid kan vere å integrere band som held fram i ein ny kvardag (Bowlby, 1980; Klass et al., 1996).

Mange modellar for sorgarbeid har vore lansert. Ikkje minst har Elisabeth Kübler-Ross (1973) sitt banebrytande arbeid om den siste livsfasen til døyande gitt opphav til skjematiske oppsett på ulike stadium i ein sorgprosess, som ofte har vore framstilt som obligatoriske viss ein skal unngå utviklinga av ein komplisert tilstand. I dag er det vanleg å sjå sorg som ein kjenslemessig tilstand ein kan gå inn og ut av. Den sokalla toprosessmodellen ser sorg som to parallelle prosessar: ein som er tapsorientert, og ein rehabiliterande eller gjenoppbyggande, der ein tar for seg konsekvensane av tapet og utfordringane det fører med seg (Stroebe \& Schut, 1999). Heller enn å lansere eit gitt, føreseieleg forløp som alle sørgande blir forventa å gjennomgå, er det no større aksept for at intensiteten i kjenslene og rytmen i vekslinga mellom sorg og normaltilstand er noko som vil variere frå individ til individ. Kva meining ein legg i tapet, er noko av det som er med på å avgjere skilnaden (Neimeyer, 2006). Skiljet mellom normal og stagnert sorgprosess står framleis ved lag. Komplisert sorg er no også med i reviderte versjonar av diagnosemanualane ICD-10 og DSM-IV (Kristensen, 2013). I dette ligg ei erkjenning av at dette er ein kompleks tilstand. Å kome vidare då kan krevje aktive tiltak. 
Det gjeldande synet på sorg og sorgarbeid i dag er sett saman av mange impulsar og er påverka frå fleire hald. I dette kapittelet skal eg gå særskilt inn på den gestaltterapeutiske tilnærminga, fordi den synest vere godt eigna for å kaste lys over prosessane eg tar for meg her. I likskap med andre former for terapeutiske tilnærmingar har gestaltterapien eit siktemål om å skjerpa medvit og auka innsikt i problem og utfordringar, særleg det som kan blokkere for utfalding og hemme ein inntrykksflyt. Jamført med mange andre meir kognitive og reint analytiske terapiformer legg gestaltterapien vekt på at ny forståing skjer gjennom ny erfaring, ein prosess som involverer kroppsleg sansing så vel som refleksjon og fortolking. Gestaltterapien ser mennesket som grunnleggjande sjølvregulerande; i utgangspunktet utstyrt med ei naturleg, ibuande evne til å oppdage og oppsøke det ein har bruk for. Denne evna eksisterer i oss som ein dynamisk og fleksibel funksjon, men ho kan også bli forstyrra og køyre seg fast.

Menneskeleg oppleving og erfaring inneber i utgangspunktet ein medvitsflyt der merksemda er retta mot det ein blir oppteken av, som ein her kallar ein gestalt, til dette blir uttømt og erstatta av ein annan gestalt, og får ei ny rørsle i forhold til denne. Uferdige erfaringar, slik gestaltpsykologane omtalar det, er eit mentalt oppheng eller etterslep frå eit handlings- eller erkjenningsforløp som har blitt avbrote før personen var klar (Polster \& Polster, 1974, s. 36). Uferdige erfaringar kan binde energien, og hindre personen i å gå vidare i ein utviklingsprosess. Når stoffet er viktig nok, vil drivet til å fullføre ifølge gestaltpsykologien halde fram til det har funne sitt uttrykk, anten ved at ein vender tilbake til den opphavlege situasjonen, eller relaterer seg aktivt til ein tilsvarande, notidig situasjon. Ved å erkjenne og gi til kjenne det som vart avbrote, vil ein kunne fullføre det uforløyste, og late att den fasthaldne gestalten.

\section{Handtering av dødfødslar i Noreg: grunntrekk og vendepunkt}

Eit sentralt premiss i gestaltterapien, som i mange andre terapeutiske tradisjonar, er at det som ikkje blir vedkjent og får kome til uttrykk, ikkje blir borte. Forteia og fornekta kan det tvert imot få stor kraft, og stå i vegen for den dynamiske sjølvreguleringa som elles karakteriserer menneskeleg 
utfalding og utvikling. Denne tankegangen har no fått stor påverknad på praksisen i norske fødeavdelingar, som har endra seg radikalt i løpet av få tiår. Dødfødslar blir i dag rekna som reelle dødsfall, verdige å minnast og markerast. Sorga over dei som døyr i mors liv, er i større grad godtatt som ei legitim sorg, og mykje blir gjort for å gi etterlatne foreldre sjanse til å ta i bruk det sterkt tidsavgrensa høvet til å ta farvel. For få tiår sidan var dette heilt annleis. Dødfødslar var dyssa ned, skjult og forteia, og barna vart oftast fjerna rett etter fødselen. Tanken var at dette var best for foreldra, som då lettare kunne gløyme det som var hendt, og gå vidare med livt sitt. Den løynde gravlegginga i andre sine graver var i samsvar med dette, sjølv om denne praksisen hadde langt eldre røter.

Korleis den fordekte gravferdpraksisen av dødfødde i Noreg oppstod og vart halden ved like fram til den kontante avviklinga på 1980-talet, er ikkje gjort mykje greie for. Dei eldste røtene går truleg tilbake til tida før reformasjonen, då vektlegginga av dåpen som sakrament og avgjerande vilkår for religiøst fellesskap vart tolka som grunnlag for ei ekskludering av udøypte på kyrkjegarden (Amundsen, 1989; Wretmark, 1993; Peelen, 2009; Kristvik, 2014). Løynd nedlegging av dødfødde i andre sine graver eller skjult plassering av små esker i kyrkjemuren var fordekte strategiar for å unngå denne utelatinga, og sikre ein plass på heilag grunn.

Esker med restar av dødfødde og aborterte foster som hadde blitt funne i grunnmuren under restaureringa av gamle kyrkjebygg, var ein del av bakgrunnsmaterialet i dokumentaren De anonymt gravlagte av Trude Teige (2005). Denne dokumentaren kom medan den tradisjonelle, løynde praksisen framleis galdt. I tillegg til det historiske materialet viste dokumentaren til den aktuelle situasjonen der mange som hadde opplevd å miste barn i mors liv, var intenst opptekne av kva som hadde skjedd med det døde barnet. Denne dokumentaren vekte mykje til live og førte til ein flaum av etterlysingar av gravene til dei som vart fødde og gravlagde i løynd. Spørsmål som lenge hadde vore haldne tilbake, og gjerne først hadde kome fram når demenssjukdom braut ned dei mentale sperrene, som heldt avstengde kjensler i sjakk, vart retta til sjukehus og prestekontor: «Kvar vart det av barnet mitt?» (Misje, 2010).

Helsevesenets kontroll over fødselssituasjonen kom med oppbygginga av sjukehussystemet, som for alvor kom i gang midt på 1900-talet. Trua 
på fordelane ved å verne etterlatne foreldre mot å bli konfronterte med tap av barn i dødfødsel, og gløyme det som var hendt fortast råd, var lenge einerådande blant helsepersonell. Flaumen av spørsmål og etterlysingar, lenge forteia, men like fullt intenst uttrykt når dei først kom fram, viste at forsøket på å verne mot sorg og smerte ikkje fungerte etter intensjonen. Uttrykket vart knebla, men behovet for svar forsvann ikkje av den grunn.

Då eg, som del av feltarbeidet mitt, var til stades ved avdukinga av minnesmerket på Stalsberghagen, vart eg sitjande ved sida av eit par som hadde mista sin førstefødde tretti år tidlegare, ein son dei aldri hadde sett. Dei hadde fått fire friske barn etter det. Like fullt gav dei uttrykk for at dei gjennom opprettinga av det nye minnesmerket på Stalsberghagen opplevde noko dei hadde venta på i tretti år.

Mot slutten av 1970-talet vart dei rådande haldningane på fødeavdelinga utfordra, noko som utløyste ein heftig debatt om psykologiske konsekvensar for kvinner som fekk sjå og halde sitt dødfødde barn (Lewis, 1976; Hughes et al., 1999; 2002). (For meir om denne debatten, sjå Wretmark, 1993; Christoffersen \& Teigen, 2013). I dag har den tidlegare skjerminga snudd til det motsette, idet ein no oppmodar nølande foreldre til å sjå, halde og stelle det døde barnet sitt, i eit medvit om ein unik sjanse til avskjed som er til stades i eit avgrensa tidsrom (LUB Krybbedødspermen).

Men før sjukehusa tok over, var heimefødslar det som var vanleg i Noreg. Då var det også familien som hadde ansvar for det som skjedde når barnet døydde. Praksisen var truleg då langt meir variabel, og nærleiken til det som skjedde større, også når barnet døydde. Ole Bernt Misje fortel om korleis barnefedrar sjølve kunne stå for gravlegging av det døde barnet, anonymt eller namngitt (Misje, 2010).

Dødfødslar har aldri vore lette å handtere. Dei har alltid markert eit brot med det ein forventar. Men medan fødslane var i regi av familien, kunne ulike, ofte motstridande kjensler brytast med kvarandre, meir ope og direkte enn kva som vart tilfellet då sjukehusa tok over. Ei skjønnlitterær skildring av ein heimefødsel der barnet døyr, er å finne i Sigrid Undsets Vaaren frå 1914. Denne forteljinga om paret som mister sin førstefødde i dødfødsel, viser korleis moras spontant uttrykte ønske om å sjå og halde sitt dødfødde barn - noko som no er heilt i samsvar med 
gjeldande normer på norske fødeavdelingar, men som den gongen verka skremmande og spesielt. Når Rose ber mannen Torkild hente det døde barnet inn til seg for å kjærteikne og stelle det steglar han, men han gjer det like fullt (Undset, 1914, s. 153).

\section{Dagens praksis: Den viktige avskjeden}

Dei gjeldande retningslinene for handteringa av dødfødslar på norske fødeavdelingar er prega av endringane som har skjedd i synet på sorg, tap og terapi. Den tidlegare strategien, som satsa på forteiing og fornekting, er erstatta av ei vektlegging av sjansen til å ta ordentleg farvel, og tilrettelegging for det som ei aktiv handling. For mange byrjar avskjedsprosessen når meldinga kjem om at det vesle hjartet ikkje lenger slår.

I nokre tilfelle er det eit fullbore barn som døyr, i samband med sjølve fødselen. Langt oftare skjer dødsfallet på eit eller anna tidspunkt før dette. Dei fleste eg snakka med, var svært merksame på faren i dei første 12 vekene. Etter det kjende dei seg trygge, og nokre sa dei slett ikkje hadde tenkt på at dei kunne miste barnet langt uti svangerskapet. At barnet ein såg fram til å innlemme som ei varig forplikting i livet, døyr før ein i det heile har fătt møtt det, er ei radikal omstilling, som oftast også kjem brått på. Tanken på å gjennomgå ein naturleg fødsel i denne situasjonen er for mange framand og urimeleg i utgangspunktet. Å sørgje for at det blir tid til å omrømme seg, er noko av det som blir vektlagt då. Når det kjem til stykket, kan fødselen også inngå i avskjedsprosessen. Fleire av dei kvinnene eg snakka med, la vekt på det å vere mest mogleg vaken og medviten undervegs, for å vere fullt til stades og kunne minnast denne økta dei hadde saman med barnet. Som ei av dei sa: «Det var iallfall noko eg kunne gjere for henne.»

Jordmødrene hastar ikkje lenger ut med det døde barnet. Foreldra blir oppmoda til å ta imot, halde og stelle den nyfødde, spesielt rett etter fødselen, når barnet enno er varmt (jf. Teigen et al., 2017). Dei fleste blir verande på sjukehuset i fleire dagar, for å få meir tid med barnet. Dette er ei tid for å samle og skape minne. Å ta vare på klesplagg eller teppe tiltenkt barnet, eller som barnet har brukt, kan inngå i dette. Likeins bandet som vart festa til handleddet for identifikasjon, ein avklipt hårlokk, og avtrykk av små hender og føter. 
Fotografering er ein viktig del av minnesamlinga. Det døde barnet endrar seg frå dag til dag, og det å bevare minna frå det første møtet kan bli svært dyrebart. Likeins fotografering saman med slektningar og venner som kjem på besøk. Bilda er med på å gjere det som har hendt, verkeleg, også for andre. At besteforeldre, andre slektningar og venner kom til sjukehuset og fekk sjå det døde barnet, vart sterkt vektlagt av mange av dei eg snakka med. Par som hadde opplevd det, fortalde at dei kjende seg mindre einsame i sorga. Det skapte også ei felles referanseramme mellom foreldra og dei nærståande. Par som ikkje hadde opplevd det, snakka om det som eit sakn.

Det å samle minne er også ein del av ein aktiv avskjedsprosess. I dag tenkjer ein altså ikkje lenger at avskjeden må føre til eit definitivt brot, der ein skal leggje ting bak seg fortast råd. No tenkjer ein meir i retning av varige band, eller integrering av tapet $\mathrm{i}$ det livet ein har. Tapet må erkjennast, men for at det skal kunne skje, må ein først vedkjenne seg kva det er ein taper. I dette inngår også det å gi namn til det døde barnet. Det har både med tilknyting og lausriving å gjere. Eigennamnet markerer at barnet ikkje lenger berre er ein del av mora.

Formaliserte avskjedsmarkeringar vil stå i ein kulturell og religiøs samanheng (Kristvik, 2016). I ein norsk kontekst er det vanleg å ha ei minnestund i sjukehuskapellet eller i den lokale kyrkja. Den norske kyrkja har ikkje nokon eigen liturgi for dei dødfødde. Den vanlege gravferdsliturgien, som er tilpassa markeringa av eit levd liv, høver ikkje heilt i denne situasjonen. Element frå gravferdsliturgien kan likevel nyttast når det stemmer for foreldra. Ulike innslag i seremonien blir sett saman i samarbeid mellom dei etterlatne foreldra og prestane. Fråveret av eigen, standardisert liturgi er ikkje berre ein mangel. Det gir også opning for å finne dei musikalske, visuelle og tekstlege rammene som gir meining for dei einskilde.

\section{Gravstad og gravlegging}

Spørsmålet om kva som skal skje med det døde barnet, er det no opp til foreldra å avgjere. Då er der fleire alternativ. Individuell gravstad med eiga gravstøtte er eit vanleg val. Andre gjer bruk av ein eksisterande 
familiegravstad. Når foreldra ikkje ønsker å involvere seg i slike markeringar i eit rituelt rom eller ein kyrkjegard, blir barnet sett ned i minnelund. Nedsetjing i minnelund kan også vere eit aktivt val for foreldre som vil ta farvel, men som ikkje knyt dette til eit ønske om å ta ansvar for ein eigen gravstad. Dei fleste norske kyrkjegardar har minnelundar som også gir rom for dei dødfødde, og stadig fleire har også eigne minnelundar spesielt for dei.

Tradisjonelt har det ikkje vore høve for pårørande å vere til stades ved gravleggingar i minnelund. Etter iherdig innsats, først og fremst gjennom pionerarbeidet til den engasjerte jordmora Liv Trønnes, har det likevel blitt opna for at etterlatne foreldre får vere til stades ved nedlegging i minnelundane for dødfødde i Oslo. Dette skjer fire gongar i året. I mange år var det Liv Trønnes som stod for leiinga då. I ein tidleg fase av prosjektet mitt fekk eg vere med på ei av desse. Ramma var enkel: Kistene vart oppstilt kring dei opne gravene før foreldra kom, med ei tent lykt framfor kvar av dei. Der foreldra hadde sagt ja til å vere med, var kistene merkte med namn. Dei andre var umerkte. Etter at representanten for gravferdsetaten, som også alltid var til stades, hadde ønskt velkomen, bar foreldra kistene fram til grava og rekte dei over til gravaren der. Ein av fedrane hadde med seg kompass, slik at han kunne finne retninga til Mekka. Kista var retta dit mens han gjekk mot grava og rekte den over til gravaren, som var påpasseleg med å halde rett posisjon då han la kista ned til dei andre. Då alle foreldra hadde overrekt sine kister, bar jordmora dei andre til grava, ein etter ein.

Dei fleste foreldra hadde med seg blomsterkransar eller bukettar, som vart med kistene i grava. Men eit par som verka litt eldre enn dei andre frammøtte, kom ikkje med blomster. Dei hadde i staden med seg eit vårgrønt babyteppe. Rett før det vart deira tur til å bere kista fram til grava, braut kvinna ut i sterk gråt. Då var jordmora straks til stades, og tok dei til sides. Paret snakka litt med jordmora før dei gjekk tilbake til grava og gav kista ifrå seg der. «Eg måtte berre forvisse meg om at dei ikkje brann inne med eit ønske om å sjå barnet sitt ein gong til», forklarte jordmora meg. Det var tydeleg at dersom dei hadde gitt uttrykk for eit slikt behov, hadde ho opna kista på nytt, for å gi dei to ein sjanse til eit siste farvel. 
Denne jordmora viser eit skarpt medvit om verdien av dei tidsavgrensa sjansane til å ta farvel. Tilbodet om å sjå det døde barnet før kista vart senka i grava, kunne auke dei sørgande sin sjanse til å fullføre ein avskjedsprosess, og unngå problematisk etterslep. I gestaltterapeutisk terminologi kunne dette gjere det meir mogleg å avslutte eller lukke ein gestalt, som altså ikkje er det same som «å bli ferdig med» ei smertefull erfaring, men å integrere denne i si livshistorie og erfaringsregister.

\section{Tap, stad og forsoning}

Som eg alt har vore inne på, var slike sjansar til å ta farvel med det døde barnet lenge svært avgrensa. Sjølv om haldningar og praksis no har endra seg radikalt, er det framleis mange som aldri har fått sett det barnet dei mista, eller fått vite kvar det vart av. Spørsmål om dette blir stadig retta til aktuelle fødeavdelingar, spesielt i etterkant av oppslag og innslag om tematikken, som dokumentaren om dei anonymt gravlagde som eg alt har nemnd. Mykje har blitt gjort av prestar og jordmødrer som fekk førespurnadane frå etterlatne foreldre på leit. I mange tilfelle lét det seg faktisk gjere å oppspore kvar barna hadde blitt av. Den anonyme gravferdspraksisen er faktisk godt dokumentert. Sjølv om foreldra til det dødfødde barnet, så vel som pårørande til den som offisielt vart gravlagt, var uvitande om kva som skjedde, vart det ofte notert i kyrkjebøkene, og kunne då stadfestast lenge etterpå.

Det å få vite kvar det vart av barnet ein mista - eit barn ein kanskje aldri fekk sjå - var for mange avgjerande for å kunne forsone seg med det som var hendt. For nokre vart det utgangspunkt for etableringa av ei symbolsk grav, idet dei fekk med seg noko av jorda frå den opphavlege grava, over til den nye minnestaden. I andre tilfelle hadde eigarane av gravstaden falle frå, og foreldra til den dødfødde kunne overta ansvaret. Men det var lenge langt frå sjølvsagt at dei etterlatne foreldra fekk tilgang til informasjonen om kvar barnet deira vart gravlagt, sjølv om dokumentasjonen låg føre. Omsynet til graveigaren overstyrte i første omgang omsynet til dei etterlatne foreldra. Etter vedvarande press vart det likevel gitt etter: I 2006 (Kultur- og kirkedepartementet, 2006) vart det slått fast at retten til eiga grav for dei dødfødde også skulle omfatte pårørande sin rett til å få vite kvar eit dødfødd barn var gravlagt. 
Men det var ikkje alle etterlysingane som førte fram til ein gravstad. I nokre tilfelle måtte oppsporingsforsøka konkludere med at barnet var handtert som organisk avfall. Trønnes fortalde at ho, då ho såg seg tvungen til å konkludere slik, sjølv hadde reist ut til Grønmo, den lokale søppelfyllinga, for å hente jord til den sørgande mora derifrå.

Ida Faye, ein sjukehusprest eg snakka med, som vart konfrontert med ein tilsvarande situasjon, valde å invitere kvinna til ei alternativ, retrospektiv avskjedsmarkering. Det var då mange år sidan denne kvinna hadde mist sitt einaste barn, som var altfor tidleg fødd. Ho budde no i ein annan by, men vende seg til presten på sjukehuset der ho ein gong var, då spørsmålet om oppsporing av gamle gravstader for dei dødfødde kom opp på den offentlege agendaen. Presten tok tak i saka, og fann dokumentasjon på at barnet var obdusert. Då ingenting var registrert etter det, forstod ho at barnet truleg var blitt destruert etter obduksjonen. Svaret til kvinna vart derfor: «Eg trur du må kome hit. Så skal vi gå den vegen saman, du og eg, som barnet ditt gjekk den gongen.»

Kvinna sa ja til invitasjonen. Den spesielle vandringa saman med presten byrja i kjølerommet. Det var der dei dødfødde låg før dei vart køyrt i omnen. Av den svære omnen var det berre pipa som stod att, men presten peikte på den: «Dit gjekk reisa for barnet ditt.» På veg bort til pipa vende presten seg mot kvinna og oppmoda henne til å leve seg inn i situasjonen: «Kan du kjenne tyngda av barnet ditt, kan du kjenne kor tungt det er å bere?» Då dei hadde gått heile vegen fram, spurde kvinna om ho kunne leggje ned nokre blomster. Ho gjekk ut og plukka det ho fann av markblomster der ikring, og la ned ein bukett ved dørstokken til rommet der omnen hadde stått. «Kan eg også få leggje ned litt oske?» spurde ho så. «Veit du?» svarte presten, «eg trur ikkje det vart noko oske att etter det vesle barnet. Det gjekk opp i luft.»

Kvinna roa seg med svaret. Men ho spurde til sist om presten kunne ta eit bilde av henne der ved blomstrane på dørstokken. Ei stund etter tok ho kontakt for å takke for den reisa dei hadde gjort, og for å fortelje at vennene hennar sa at det var som ho var blitt langt yngre etter reisa til Oslo. Noko hadde sleppt taket. Sorga var der framleis, men den tyngde henne ikkje slik som før.

Det presten gjorde her, står i skarp kontrast til den tidlegare praksisen om å unngå og verne seg mot såre kjensler, og gløyme fortast råd. 
Historia til denne kvinna viser også at den strategien ikkje verka. Men det er viktig å merke seg at det presten gjorde, var eit svar på kvinna sitt initiativ. Ei slik ritualisert tilbakereise vil ikkje vere det rette for alle, og vil ikkje vere aktuell å gjennomføre utan ei tydeleg melding om eit behov.

Korleis presten svarte dei som vende seg til henne med spørsmål om kvar barnet deira var blitt av, handla slik ikkje berre om det som var hendt, men også om måten behovet kom til uttrykk på. Eit anna døme Faye nemnde for meg, var eit tilfelle der ho kom fram til at barnet var lagt i ein minnelund. Også då vart presten med på ei reise tilbake, då til gravlunden. Då hadde ho først oppmoda kvinna til å skrive brev til barnet, eit brev dei tok med seg ut til minnelunden. Der tende dei lys, og brende brevet som ei rituell markering av tapet.

Handlingar som dette kan tolkast som aktive grep for å fullføre det uforløyste, det som innan gestaltpsykologien blir kalla closure of unfinished business. Å leggje markblomster på terskelen til rommet med forbrenningsomnen, eller brenne eit brev på minnelunden, er handlingar som kan verke forsonande, og få den sørgande til å kome fram til ei avslutting på det som har blitt «hengande» som tappande energisluk. I andre tilfelle kan det handle om framskaffing av ein dødsattest, eller etablering av ei symbolsk grav. I dette ligg det ikkje at smerta blir borte, men at ein kjem ut av ein tilstand der all energi blir bunden opp i det som har hendt. Ein føresetnad for at det skal verke slik, er at dette gir meining for den det gjeld, og står i samsvar med eit opplevd behov.

\section{Grensedraging og gråsoner i byrjinga av livet}

Kva det betyr å miste eit barn før det er fødd, kan ikkje avgjerast på eit generelt plan. For den innsikta må ein gå til den einskilde (Jutel, 2006). Noko av det som kan spele inn, er når i svangerskapet avbrotet skjer, kulturelt og religiøst rammeverk, og sosioøkonomiske forhold (Hockey, \& Draper, 2005; Kaufman \& Morgan, 2005).

Spørsmålet om når livet byrjar, og når eit avbrot blir rekna som eit rettmessig dødsfall, har ikkje noko eintydig svar. Grensa for registrering av dødfødslar i det nasjonale fødselsregisteret her til lands er sett til 22 veker. WHO lar grensa gå 6 veker seinare, og definerer dødfødde som dei 
som blir fødde utan teikn til liv etter 28 vekers svangerskap. Nokre land trekker skiljelina på anna vis, og gjer grensa avhengig av vekt (dvs. eit minimum på 500 gram), heller enn gestasjonsalder (Lawn et al., 2016).

For tilgang på etablerte sorggrupper i regi av eit av sjukehusa der eg gjorde feltarbeidet mitt, er det sett ei grense som svarar til den som blir brukt for den nasjonale statistikken: 22 veker. Tilbodet om å vere med i ei gruppe gjeld dei som mister barn etter det. Det er grunn til å rekne med ein samanheng mellom når i svangerskapet tapet skjedde, og etterlatne foreldre sitt behov for støtte til sorgarbeid. Men det er ingen automatikk i dette.

Intervjumaterialet mitt inkluderer døme på foreldre som har mist barn få dagar før denne grensa, og som då er stengt ute frå eit tilbod dei sårt kjenner behov for.

Eit avgjerande skilje i byrjinga av livet går ved 12 veker; dvs. grensa for sjølvbestemt abort. Stadfestinga av ein graviditet kan vere sterkt etterlengta, knytt til intens lukke og forventing. Og som påpeikt av ei kvinne som høyrde om prosjektet mitt: For nokre kan den månadlege menstruasjonsblødinga vere ei stadig påminning om skøyrt håp - som brest. Men ein graviditet kan også vere knytt til intens fortviling, for den som ikkje ser seg i stand til å ta imot eit barn.

Høvet til å avbryte eit svangerskap er ein hardt tilkjempa rett, ei viktig kampsak for kvinnerørsla over lang tid. Likevel kan lite takast for gitt med omsyn til kjenslemessige reaksjonar når ei kvinne søker abort, og får utført eit svangerskapsavbrot. Letten over å få gjennomført det som verkar tvingande naudsynt, kan skugge over alt anna i ein pressa situasjon. Det vil ikkje seie at den som ber om eit abortinngrep, ikkje kan kjenne på sorg og fortviling over denne avgjerda. Sorga etter ein abort er blitt kalla ei einsam og ordlaus sorg (Worden, 2010, s. 197). Ei forsvarleg handtering av denne komplekse tematikken ville sprenge rammene for dette kapitellet. Viss plassen hadde gitt rom for det, kunne ein vist til fleire skjønnlitterære døme som inkluderer forsøk på å gi uttrykk også for dete sorga, og late att ein gapande gestalt (Nedreaas, 1947; Larsen, 1989).

\section{Nokre ord til slutt}

Med tanke på den korte tida det er sidan dødfødde barn vart gravlagde i løynd, er det svært mykje som har skjedd på få tiår. Frå å ha vore eit 
ikkje-tema om dei som døyr i mors liv, er retten til eiga grav no lovfesta som ein eintydig rett utan aldersgrense. Dette er ei stor omstilling, der kyrkja har gått inn for ein regel som er meir fleksibel enn andre reglar på feltet. Som minnesmerket på Stalsberghagen er uttrykk for, er dette ei haldningsendring som ikkje berre gir nye vegar å gå for dei som opplever ei form for graviditetstap. Den omfattar også oppgjer med tidlegare praksis, prega av forteiing og neddyssing, og ei vedkjenning av den smerta som for mange framleis er knytt til det. Den radikale haldningsendringa som har skjedd blant helsepersonell som møter etterlatne foreldre etter ein dødfødsel, har ikkje berre gjort dei i stand til å støtte dei etterlatne til å stå i sorga, og avverje kompliserte sorgreaksjonar. Omsorgs- og innsiktsfulle hjelparar kan også medverke til at dei som kjem med gamal sorg, finn uttrykk for det smertefulle på forløysande vis.

Heller ikkje i dag er det alle som får ei eiga grav. Det har heller ikkje vore intensjonen med den nye lovreguleringa. Men no er oppretting av eigen gravstad, bruk av eksisterande familiegrav eller nedsetjing i minnelund eit val det er opp til dei etterlatne foreldra å ta stilling til. Den nye praksisen opnar for ei vedkjenning av at omfanget av sorg ikkje kan avgjerast av nokon som kjem utanfrå, heller ikkje sorga over dei som døyr i mors liv.

\section{Referansar}

Amundsen, Arne Bugge (1989). Folkelig og kirkelig tradisjon. Dåpsforståelser sæerlig på 180o-tallet. Oslo: Solum Forlag.

Bowlby, John (1980). Attachment and Loss: Loss, Sadness and Depression (Vol. 3). London: Hogarth.

Christoffersen, Line, \& Teigen, Janne (2013). Når livet slutter før det begynner. Foreldres opplevelser etter en dødfødsel og det etterfølgende svangerskapet. Oslo: Abstrakt forlag.

Freud, Sigmund (1917). «Mourning and Melancholia» The Standard Edition of the Complete Psychological Works of Sigmund Freud, Vol XIV (1914-1916): On the History of the Psycho-Analytic movement, Papers on Metapsychology and other Works, 237-258.

Hockey, Jenny, \& Draper, Janet (2005). Beyond the Womb and the Tomb: Identity, Embodiment and the Life Course. Body and Society, 11(2), 41-57. https//doi. org/10.1177/1357034X05052461 
Hughes, Patrica, Turton, P., Hopper, E., \& Evans, C. D. H. (2002). Assessment of guidelines for good practice in psychosocial care of mothers after stillbirth: A cohort study. The Lancet, 360(9327), 114-118. https://doi.org/10.1016/So14O6736(02)09410-2

Hughes, Patricia M., Turton, P., \& Evans, C. D. (1999). Stillbirth as risk factor for depression and anxiety in the subsequent pregnancy: Cohort study. BMJ, 318(7200), 1721-1724. https://doi.org/10.1136/bmj.318.7200.1721

Jutel, Annemarie (2006). What's in a name? Death before birth. Perspectives in Biology and Medicine 49(3), 425-434.

Kaufman, Sharon, \& Lynn Morgan (2005). The anthropology of the beginnings and ends of life. Annual Review of Anthropology 34, 317-341.

Klass, Dennis, Silverman, Phyllis R., \& Nickman, Steven. (1996). Continuing Bonds: New Understandings of Grief. Washington, DC: Taylor and Francis.

Kristensen, Pål (2013). Sorg som diagnose. Tidsskrift for den norske legeforening $133(8), 856$.

Kristvik, Ellen (2016). Traditions in transition: Practices related to stillbirth in a multicultural society. I Nate Hinerman \& Mary Ruth Sanders (Red.), Care, Loss and the End of Life (s. 139-147). Oxfordshire: Inter-Disciplinary Press.

Kristvik, Ellen (2014). In memory of children who die before being known. A ritual field in a formative phase. I Carol McAllum \& Madeline Gorman (Red.), Mapping the Perimeter of Death and Dying (s. 139-146) Oxfordshire: InterDisciplinary Press.

Kultur- og kirkedepartementet (2006). Rundskriv V-18 B/2006. Henta frå https://www.regjeringen.no/no/dokumenter/rundskriv-v-18-b20o6/id109635/ (Lasta ned 5. sep. 2017).

Kübler-Ross, Elisabeth (1973). Før livet ebber ut. Oslo: Gyldendal Norsk Forlag. Larsen, Britt Karin (1989). Du er likevel til. Brev til et barn som ikke ble født. Oslo: Gyldendal Norsk Forlag.

Lawn, Joy E., et al. (2016). Ending preventable stillbirths 2. Stillbirths: Rates, risk factors, and acceleration towards 2030. The Lancet (387) 587-603. Henta frå http://www.thelancet.com/pdfs/journals/lancet/PIISo140-6736(15)oo837-5.pdf (Lasta ned 19. feb. 2018).

Lewis, Emanuel (1976). «The management of stillbirth - coping with an unreality.» The Lancet ii: $619-620$.

LUB. Krybbedødspermen, lagt ut på Helsebiblioteket. Henta frå http://www. helsebiblioteket.no/retningslinjer/krybbed\%C3\%B8dspermen/1-akutt/1.5utfyllende-veileder (Lasta ned 5. sep. 2017).

Misje, Bent-Inge (2010). «Hvor ble det av mitt barn? En undersøkelse om kirkens behandling av dødfødte barn i Norge.» Olavsstipendet for prester. Rapport. Nedreaas, Torborg (1947). Av måneskinn gror det ingenting. Oslo: Aschehoug. 
Neimeyer, Robert A. (2006). Bereavement and the quest for meaning: Rewriting stories of loss and grief. Hellenic Journal of Psychology 3, 181-188.

Peelen, Janneke (2009). Reversing the past: Monuments for the stillborn children. Mortality, 14(2), 173-186.

Polster, Erving, \& Polster, Miriam (1974). Gestalt Therapy Integrated. Contours of Theory and Practice. New York: Random House.

Romerikes Blad (2009, 8. mai). Kan få minnes-merke. Henta frå https://www.rb.no/ lokale-nyheter/kan-fa-minnes-merke/s/1-95-4318147 (Lasta ned 5. sep. 2017).

Stroebe, Margaret, \& Schut, Henk (1999). The dual process model of coping with bereavement: Rationale and description. Death Studies, 23, 197-224.

Teige, Trude (2005). De anonymt gravlagte. TV-dokumentar, TV2.

Teigen, Janne (2017). Dødfødsel/ intrauterin fosterdød etter 22. svangerskapsuke psykososial oppfølging. Fagprosedyrer lagt ut på Helsebiblioteket. Henta frå http://www.helsebiblioteket.no/fagprosedyrer/ferdige/dodfodsel-intrauterinfosterdod-etter-22-svangerskapsuke-psykososial-oppfolging (Lasta ned 19. feb. 2018).

Undset, Sigrid (1914). Vaaren. Kristiania: Aschehoug \& co.

Walter, Tony (1999). On Bereavement. The Culture of Grief. Maidenhead: Open University Press.

Worden, J. William (2010). Grief Counseling and Grief Therapy. A Handbook for Mental Health Practitioners. London: Routledge.

Wretmark, Astrid Andersson (1993). Perinatal Death as a Pastoral Problem. PhDavhandling. Uppsala: Bibliotheca Theologiae Practicae. Kyrkovetenskapliga studier 50. 


\title{
Claes Gill om den andres død og den egne. En lesning av «Portrett av en avdød venn» i lys av Heideggers dødsfilosofi
}

\author{
Arnfinn Åslund \\ Universitetet i Sørøst-Norge
}

\begin{abstract}
Summary: Claes Gill (1910-1973) was a Norwegian poet and actor. He published only two books of poetry, but this was sufficient to establish him as a symbolist and modernist pioneer. This essay focuses on his preoccupation with death, especially in the enigmatic «Portrait of a Deceased Friend» from 1939. The theoretical framework consists of the existentialist hermeneutics of death presented by Martin Heidegger in his major work Sein und Zeit (1927). This contribution is still highly relevant for discussions on death and mortality. Some of his views on individuality and sociality (Mitsein, «being-with») in relation to death have been questioned. Our interpretation of Gill's poem tries to clarify an important aspect of this difficult part of Heidegger's philosophy. It is only when recognizing the individuality of death that one can truly be of help to the other in his relation towards death.
\end{abstract}

Keywords: Gadamer, Claes Gill, Heidegger, modernist poetry

\section{Introduksjon}

Helt siden antikken har døden vært et hovedtema i europeisk lyrikk. Slik er det også hos Claes Gill. Hans status som modernistisk pioner beror på to samlinger: Fragment av et magisk liv fra 1939 og Ord i jorn fra 1942. Den første er både den mest eksperimentelle og den mest slående. Her finner vi det gåtefulle «Portrett av en avdød venn».

Diktet er relevant for eksistensfilosofiske diskusjoner om døden, som den vi finner i Martin Heideggers analyse av dødsfenomenet i Sein und Zeit fra 1927, et bidrag av vedvarende interesse. I en nylig utkommet antologi om døden skriver den finske filosofen Sara Heinämaa: «In the study

Sitering av denne artikkelen: Åslund, A. (2018). Claes Gill om den andres død og den egne. En lesning av «Portrett av en avdød venn» i lys av Heideggers dødsfilosofi. I A. Johannessen, N. Askeland, I. B. Jørgensen \& J. Ulvestad (Red.), Døden i livet (Kap. 7, s. 119-135). Oslo: Cappelen Damm Akademisk. https://doi. org/10.23865/noasp.40.ch7

Lisens: CC BY-NC 4.0 
of death and mortality, Heidegger's hermeneutical phenomenology has long been the dominant discourse» (Heinämaa, 2015, s. 101).

For Heidegger representerer dødsmuligheten en irredusibel «min-het». Den er knyttet til min eksistens og kan ikke overtas av andre. Heidegger bruker «derværen» (Dasein) som betegnelse for menneskets væremåte. Det betyr at mennesket alltid er «der» som et forhold til væren. Eksistensen er det fremtidsrettede ved der-væren, mulighetsrommet som avdekkes med tanke på fortsettelsen. Ettersom døden innebærer et forhold til slutten, representerer den også derværens mulighet til å forholde seg til tilværelsen som helhet. At dødsmuligheten er eksklusivt knyttet til den enkelte, synes å innebære en lukning om den egne eksistensen som står i strid med Heideggers vektlegging av medværen som grunnleggende i menneskets væremåte. Dette betyr at medværen alltid allerede er et moment i der-værens tilværelse. Sosialiteten er like opprinnelig som individualiteten. Den engelske filosofen Simon Critchley har kritisert Heidegger på dette punktet, det samme har den norske filosofen Vigdis Songe-Møller gjort. I Heideggers begrep om ikke-relasjonalitet, som dreier seg om det individualiserte ved døden, finner hun en tanke om selvtilstrekkelighet som vanskelig kan forenes med medværen (Songe-Møller, 2012). Her ser hun en apori i Heideggers filosofi. En hypotese for vår lesning er at diktets sammenstilling av død og vennskap kan oppklare dette problematiske punktet.

Diktets tittel peker mot det mer overgripende forholdet mellom språket og døden, og dette angår lyrikkfortolkningens teori og metode. I kraft av sin soliditet fastholder skriften kontrasten mellom våre tankers inderlighet og tegnenes utvendighet, mellom de levendes presens og de dødes perfektum. Parallelle synspunkter finner vi i Hans-Georg Gadamers diskusjon av skriftens temporalitet i Sannhet og metode. Det handler om muligheten for en levendegjørende aktualisering av overleverte meningsobjekter. Skriftmediet har en egenartet dobbelthet:

Skriften og litteraturen, som har del i skriften, er åndens mest fremmedgjorte og ytre form. Skriften er det reneste spor av ånd, samtidig som intet er mer avhengig av en forstående ånd enn skriften. Det skjer et mirakel når skriften blir dechiffrert og tydet, en forvandling av noe fremmed og dødt til en absolutt 
samtidighet og fortrolighet. Dette ligner ikke på noen annen overlevering som kommer til oss fra fortiden. [...] Den som er i stand til å lese skriftlige overleveringer, bevitner og fullbyrder fortidens rene nåtid. (Gadamer, 2010, s. 196)

Lyrikkfortolkningen forsøker å gjøre fortid til nåtid - slik også Gills portrettdikt fremstiller sin avdøde venn som levende nærvær. I Det skjønnes aktualitet fra 1977 fremholder Gadamer at kunstens opprinnelse ligger i menneskets tilbøyelighet til lek og spill, men like viktig er døden. Selv om alt skal forsvinne, finnes en kulturens relative varighet som er en forutsetning for sivilisasjon. For den skapende kunstner og for den medskapende mottager er det å skjenke varighet en avgjørende impuls. Litteraturfortolkningen er solidarisk med verkets fortsatte liv. Gadamers nøkkelbegreper er spill, symbol og fest. Spillet viser til deltagelsen som forutsetning for kunstverket. Tilegnelsen er en dialog der verket blir subjekt. Det symbolske angår det eksistensielle erkjennelsesaspektet, mens festen fremhever det sosiale og inviterende ved kunstnerisk kommunikasjon. Ordet «fest» innebærer ikke nødvendigvis en euforisk partystemning. Det kan være den tyngste sorg som samler oss. Som festen har også kunstverket sin egen tid og sitt eget sted. Å dvele i verket er metoden.

\section{Fragment}

På vei inn i diktet merker vi oss først konteksten. Samlingen heter altså Fragment av et magisk liv. Denne assosiasjonssterke tittelen har en implisitt dødsreferanse. Den mest drastiske fragmenteringen av organismen setter inn når livet opphører. Tittelen gir det fragmentariske en metastatus overfor de enkelte diktene. Innenfor hermeneutikken er mening utlagt som et spill mellom helhet og del. Ettersom det fragmentariske angår nettopp dette forholdet, blir tittelen en påminnelse om det problematiske ved fortolkningen. Åpningsdiktet slår an dødstemaet: «gi ord, o tvil - hvad skjer/når øiet lukkes av jord - jord». Døden er den erkjennelsesimpulsen som driver prosjektet helt til avslutningsdiktets konklusjon: «Død er det hellige vanvidds lodd.»

«Portrett av en avdød venn» ble første gang trykket i Samtiden i 1936. En viss «modning» har altså skjedd når det kommer i bokform i 1939: 


\section{Portrett av en avdød venn}

Så blev da rammen engang den:
en tropisk natt
betændt av hvit og giftig duft
heliotrop og vannsyk jord
et lummert kratt
omkring en halvtom bar
i døsig lys og muggen luft

Og så en blind, alene ved et bord,

klimprende gitar,

da tiden risset siste strek

i det som blev en venns portrett.

$\mathrm{Nu}$ fullført i en rask retrett

fra denne meningsløse lek.

Hvad sier denne form: en spinkel kropp

en giftig formel skapt i ben og blod,

hvad eller en funksjon av Pauli' ord,

hvad vet vi vel om disse ting;

hvad vet vi vel om dette blikk?

foruten det vi ser: et gjenfærdsskjær

av vold og brann langs med Adige,

og sidenhen et likhvitt skinn av kokain.

Vi hører disse ord:

kanhænde er det dette syn

av lotusblomst i vårhvitt flor

som ikke er, men engang var;

kanhænde har jeg sett mig mett.

Og vi, hvad kan vi si

som angår ham og ikke oss? 
Og så igjen:

kanhænde er det denne krig

i tredve år om liv og død

som ikke er, men engang var;

kanhænde har jeg gått mig trett.

Og vi, hvad kan vi ikke si

som undgår ham, om ikke oss.

Og som svar på vertens skrik:

et skudd! hvem skjøt? o, se et lik!

Hvad kan vi si og ikke si

som stiller fritt en venns portrett

i rammen, som den engang var:

et nattlig bar-rum

tropisk hett

klimprende gitar

Det er en dramatisk scene. Et skudd er avfyrt, og en mann er død. Diktet presenterer også rommet hvor hendelsen finner sted. Gill hadde oppholdt seg en tid i Latin-Amerika, og den mørke troperomantikken trekker nok veksler på erfaringer derfra, men teksten er fattig på geografiske og biografiske referanser. Den eksistensielle problematikken står nakent frem.

Denne studien inngår i et flerfaglig prosjekt, så vi konsentrerer oss om innholdet og trekker inn lyrikktekniske forhold kun hvor de har spesiell betydning. Her kan nevnes at det påfallende oppsettet antyder forskjellige stemmer eller nivåer i diktet. Det er utpreget modernistisk, men ikke uten regelmessighet. Med kun tre unntak er det gjennomført jambisk versemål, og det er mannlig enderim nesten hele veien, men rimspennet varierer, og fullrim alternerer med halvrim. De metriske unntakene representeres av tre linjer som har trykksterk åpning: «klimprende» (to ganger) og «tropisk». Den jambiske strukturen brytes i tredje siste linje med spondeen «bar-rum». 


\section{Portrett}

Det er tradisjon å tale om littercere portretter, men portrettbegrepet innebærer like fullt en overføring fra bilde til tekst. Bildekunstens terminologi preger diktet: portrett, ramme, risse, strek. Metaforikken utvides slik at også tiden blir portrettør. Dermed handler portretteringen om selve virkeligheten. Den får en ontologisk dimensjon. Diktet er et portrett som handler om å portrettere også i eksistensiell forstand.

Portrettets muligheter ble utvidet med oppfinnelsen av fotografiet. I diktet leser vi: «Hvad vet vi vel om dette blikk?» Her manes blikket frem i sin uutgrunnelighet. Er det den avdødes levende blikk eller hans døde øyne? Omtrent samtidig med Gills dikt skriver Walter Benjamin at fotografiets reproduksjonsmuligheter bidro til å svekke den aura som omgir tradisjonens kunstverk. Men portrettfotografiet er auraens siste tilholdssted. Blikket ser tilbake på betrakteren, og den auratiske kraften potenseres når portrettet viser en kjær avdød (Benjamin, 2014, s. 376). Diktet bruker nyordet «gjenfærdsskjær» om avdødes blikk. Gjennom blikket som manes frem, bevares et fragment av et magisk liv. Gjenferdsskjæret blir en metafor for diktet selv.

Det glimtvise ved diktet minner om fotografiets evne til å rive øyeblikket ut av den episke sammenhengen og fryse det fast med lysets skrift. Vennen opptrer uten identifiserbart ansikt. Auraen fanges idet den forsvinner. Paradoksalt nok kan anonymiteten virke intimiserende, som om avdøde utelukkende hører til det lyriske subjektets nære krets, $i$ et personlig vennskap. Vi trekkes inn i pendlingen mellom sjokkpreget nærhet og kunstnerisk distanse. Avdødes navn har ikke offentlig interesse, for det dreier seg om noe viktigere enn navn. Anonymiteten understreker det navnløse intet, men åpner også opp diktet. Dødens vilkår gjelder oss alle.

Portrettbegrepet har referanse til oppdragskunst og leilighetsdikt. Minnedikt kan fungere som rituell brukspoesi ved sørgehøytiden. Slike dikt viser tilbake til den dødskult som Gadamer regner som en av kunstens kilder. Modernismen står i et spenningsfullt forhold til slik heteronomi. Selv om også brukskunst preges av det eksperimentelle formspråket, vil en binding til en institusjon legge føringer som kan true autonomien - det å stille portrettet fritt - som det heter på slutten av diktet. Diktet er viet 
saken uten hensyn til kollektivt seremoniell. Pronomenet «vi» kan minne om en konkret sørgeforsamling, men peker snarere mot menneskehetens «vi». Slik vi alle er utlevert til samme endelikt, for «annerledes er det ikke innrettet for oss mennesker», sier Sapfo (2005). Men i diktet er den døde skilt fra det levende «vi» med sin tale i førsteperson, døden lukker oss om vår mest egne mulighet.

Åpningslinjen nevner «rammen», og ordet gjentas mot slutten. En ramme markerer et bildes avgrensning mot det som er utenfor. Den markerer verkets selvstendighet og angår forholdet mellom fiksjon og virkelighet. Landskapsbildets ramme gjør bildet til et vindu mot verden der ute. Her er det omvendt. Gjennom rammen ser vi inn i baren. Det er brukt preteritum når «rammen» omtales. Adverbet «engang» markerer det singulære ved hendelsen, men assosierer også til eventyrets innrammende fiksjonsmarkør «det var en gang». Preteritumsformen markerer det avsluttede ved det som befinner seg inne i rammen. Tidens uavvendelighet blir selv en ramme, grensen for det som var, men som ikke lenger er. Men selve rammen blir et tvetydig overgangsfenomen, en dobbelthet som diktet demonstrerer. Ved at den lyriske stemmen benevner rammen innlednings- og avslutningsvis, skjer en performativ innramming av motivet, samtidig som denne rammen utgjør en del av det større portrettet som tittelen presenterer. Ettersom vi forstår at diktet opererer med ramme i metaforisk forstand, problematiseres ordets grensesettende funksjon, også når det dreier seg om kunstens grense mot det som ikke er kunst. Den estetiske grensesettingen kobles på den mer fundamentale grensesettingen mellom liv og død. For når rammen omtales, dreier det seg om å innkretse døden, som selv er livets ramme, men slik at døden samtidig er del av livet; den står inn i eksistensen som dens mest egne mulighet. Åpningslinjen avsluttes med det første av i alt sju kolon. Disse skilletegnene har også en rammefunksjon - de markerer innholdsmessige overganger, vekslinger mellom forskjellige virkelighetsplan.

\section{Tropisk}

Diktet plasserer oss i tropene, åpenbart i regntiden, for jorden er «vannsyk». Opphopningen av assosiasjonsrike nominalledd gir et sanselig 
nærvær. Stemningen er dekadent. Luktesansen utfordres av ubehagelige inntrykk. Adjektivene brukes metaforisk og metonymisk. Krattet er «lummert», her knyttes nattemørke og luktinntrykk til den trykkende fornemmelsen som varsler et kommende uvær. Påfallende nok er duften $h v i t$, slik man kunne se for seg sigarrøyk fra baren, men med koblingen til betennelse og gift minnes vi om at hvitt også er dødens farge, slik det tydeliggjøres med sammensetningen «likhvitt» lenger nede, hvor hvitheten kobles til kokain. Kort etter hvitheten kommer det litt påfallende «heliotrop». Her aner vi blomsternavnet hvit heliotrop, som alluderer til diktet «White Heliotrope» av Arthur Symons (1974), en forfatter Gill var opptatt av. Hvit heliotrop er en giftig parfymeplante. Hos Symons er duften uadskillelig fra den nedtrykkende atmosfæren $\mathrm{i}$ «the feverish room», hvor den syke kvinnen ligger.

Sammenstillingen av «tropisk» og «heliotrop» i samme strofe assosierer til det tropiske i betydningen billedlig språkbruk. Grunnbetydningen av «trope» har å gjøre med å vende eller snu. En heliotrop plante vender seg etter solen (helios). I diktet blir «heliotrop» grammatisk tvetydig: Ordet kan være både substantiv og adjektiv, en mulig lesemåte er at det er den vannsyke jorden som er heliotropisk. Det er vanlig å regne med fire mestertroper: metafor, metonymi, synekdoke og ironi. Sammenstillinger som «døsig lys» og «muggen luft» er metonymiske. Her indikeres det at lyset er svakt og stemningen søvnig. I den stillestående og fuktige luften kjennes duften av mugg. Det er altså kontakt eller nærhet, og ikke likhet, som forbinder leddene. Situasjonen er mettet av gift, betennelse og sykdom.

Det synekdokiske er operativt når de impresjonistiske detaljene maner frem en hel verden. Vi ser for oss det sosiale livet omkring baren. Nå er den «halvtom», noe som ikke er synonymt med halvfull. Ordene har forskjellig dynamikk: At en bar er halvfull, gir et mer forlatt inntrykk. Gadamer snakker om analogien mellom kunstverket og festen, men her er festen i ferd med å ebbe ut. Om diktet inviterer oss inn, er det til selskap med døden. Bildet peker utover det nære miljøet, det peker mot en større verden og gestalter seg som en representant for denne: 1930-tallets depresjon med sår etter forrige storkrig - og på vei mot neste, kunne man si i retrospekt. 


\section{Tidens riss}

Den forlatte stemningen forsterkes i neste avdeling. Den blinde gitaristen er kunstens representant i diktet, tett på døden. Han sitter alene, og spillet hans kan ha vært mer intenst tidligere på kvelden. Blindheten kan virke skjerpende, man blir mer var for stemningsskifter. Gitaren er et klimpreinstrument, så verbet «klimpre» er langt fra påfallende, men det kan også konnotere en mer nølende måte å spille på: Han demper musikken for å høre hva som foregår i rommet.

Selve dødsbegivenheten er fremstilt figurativt: «tiden risset siste strek». Her er tiden blitt portrettkunstner, metaforikken gjør virkeligheten til kunstverk. Tiden tegner våre liv, og med siste strek er portrettet fullført. Ordet «retrett» er en eufemisme for å dø, og begrepet forutsetter et aktivt subjekt. Man er ikke objekt for en handling utført av andre. Altså må dødsfallet forstås som selvmord. Senere fremgår det at døden kom etter et skudd. Vennen har skutt seg (Gill, 1995, s. 86, Hagerups etterord).

At tiden risser, er en tankevekkende metafor. Verbet hører sammen med substantivet riss. Vi har vist til Heideggers dødsfilosofi, hvor tiden er fundamental. Senere vektlegger han risset i Kunstverkets opprinnelse (Heidegger, 1950/2000). Et riss kan være et lineært spor: en rift eller en revne. Det tyske ordet Riss henger sammen med reissen, som også har betydningen å rive. På norsk kan substantivet riss ha revne og rift som bibetydninger. Et riss markerer dermed en skillelinje som etablerer to motsatte sider: de to sidene av risset eller revnen. Det risset som interesserer Heidegger, er revnen mellom jorden og verden. Disse ledeordene inngår i diskusjonen av sannhet, forstått som den striden mellom tildekning og avdekning som kunstverket iverksetter: «I og med at en verden åpner seg, så trer jorden frem» (Heidegger, 2000, s. 74). I denne åpningen avdekkes menneskets mulighet for fortsatt eksistens: Risset er ikke bare en revne, det er også en plan eller et utkast: «Revnen er et grunnriss. Den er et ut-kast som tegner grunntrekkene til hvordan det værendes lysning åpner seg» (Heidegger, 2000, s. 74-75). Vi er kastet inn i verden og utlevert til vårt eget utkast. Hos Gill er det tiden som risser. Tidens riss er revnen mellom det som var og det som skal komme. Dette er den revnen mennesket står i, hvor åpningen skjer, hvor muligheten for fortsettelse av væren-i-verden risses opp. 
Tidens «siste strek» er en grense. At mennesket eksisterer, vil si at det har en fremtid, hvilket innebærer at det gjør utkast for fortsatt eksistens. Når mennesket er fratatt sin fremtid, har det heller ikke noen eksistens. Da har omslaget skjedd, omslaget fra et værende som eksisterer, til et værende som bare er for hånden, én ting blant andre ting. Heidegger diskuterer om begrepet om å være avdød representerer et mellomværende. Mennesker som har stått oss nær, synes å fortsette med det etter sin død. De blir ikke helt redusert til ting:

Til forskjell fra den som bare er død, er den «avdøde» blitt revet bort fra de «etterlatte» og blir gjenstand for «besørging» i form av sørgehøytid, begravelse og gravpleie. Dette skyldes at den avdøde i sin værensmåte er «mer» enn en ren bruksting som er omverdenslig til hånden og som kan besørges. Når de etterlatte dveler ved den avdøde gjennom å sørge over ham og minnes ham, er de hos den avdøde i modus av ærbødig forsorg. (Heidegger, 2007, s. 253)

Men Heidegger fremhever at den døde selv ikke inngår i fellesskapet. Avdøde er bare et minne i vår verden. De andre erfarer ikke den andres død - som det «å være-kommet-til-ende». Så lenge man kan erfare, er man ikke død. Og når man er død, kan man ikke erfare. Det går en grense mellom fellesskapets medværen og døden som min mest egne mulighet.

Vennens portrett omtales i preteritum: Det «blev» et portrett, det er «fullført». Tidens åpnende riss lukket seg med selvmordet som siste utkast. Når livet er fullført, kan det ikke erfares som om man har nådd et mål. I det øyeblikk portrettet er fullført, kan ikke den portretterte betrakte det. Om portrettet skulle være en metafor for den avdødes liv, blir dette utilgjengelig for avdøde i det øyeblikket det er ferdig. Det blir bare tilgjengelig for de etterlatte, og ettersom de ikke kan erfare døden i avdødes liv, har heller ikke de tilgang til et «fullført» bilde av avdødes liv. For den eksisterende er livet alltid u-fullført. Det å se innebærer å kartlegge eksistensens mulige fortsettelse. Kun for den andres blikk er det fullførte portrettet synlig. I diktet fremstilles dette som et paradoks: Portrettet er «fullført $i$ en rask retrett». En retrett innebærer tilbaketrekning fra de andres synsfelt, ut av det bildet de andre har av en, ut av portrettet. En slik retrett innebærer eksistensens forsvinning i samme øyeblikk som den fullføres. Den blir synlig som fullført portrett i det øyeblikk den blir usynlig. 
Eksistensen trekker seg tilbake fra «denne meningsløse lek». For Gadamer er mennesket et lekende vesen. Eksistensens riss er dypest sett å lage et selvportrett. Lekens kreativitet inngår i prosjektet med å finne mening i verden. Vår forstående aktivitet kan oppleves som meningsfull nok, inntil det slås en revne som avdekker fraværet av grunnleggende mening. Eksistensens mening har et menings-løst grunnlag. Den har ingen annen grunn enn eksistensen selv. Denne erfaringen har angsten som stemningsuttrykk. Alt blir likegyldig. Meningens grunn er det grunnløse intet som vitner om døden. Møtet med dette kan paradoksalt nok gi en type forankring. For i dette møtet kan der-væren overta sin egen eksistens ut fra forutsetningen om at livsmeningen ikke er gitt på forhånd som et trygt fundament. Døden kan bare erfares som et fenomen i livet. Ved at angsten rykker oss ut av det tildekkende forholdet til døden, kan vi få et forhold til eksistensen som helhet. I avgjørelsen om eksistensens fortsettelse finnes verken fasit eller risikofrihet:

Verden er snarere en lysning som fremkommer ved at alle viktige avgjørelser slutter seg sammen til retningsgivende anvisninger. Hver avgjørelse har imidlertid sitt grunnlag i noe ikke-behersket, skjult, villedende, ellers ville det ikke være en avgjørelse. (Heidegger, 2000, s. 63)

\section{En giftig formel}

Diktet går nå inn i en refleksiv modus som preges av en rekke spørsmål. Spørreordet «Hvad» opptrer sju ganger, og det formodende «kanhænde» brukes også spørrende. Konfrontasjonen med plutselig død reiser temaet om livets mening. Det første spørsmålet er retorisk: «Hvad sier denne form.» For problemet er at denne døde kroppen ikke sier noe. Spørsmålet peker bare tilbake på den spørrende, mot intet. En dødsmetafor introduseres når mennesket sammenlignes med «en giftig formel». Organismen er programmert til å dø. Ordet «formel» indikerer et kvasivitenskapelig perspektiv, mens det giftige minner oss om døden som del av livet. I neste linje kommer det religiøse perspektivet som et kvalitativt alternativ. Apostelen Paulus var en av kristendommens grunnleggere. I Apostlenes gjerninger taler han for filosofene i Aten - om oppstandelsen og om Gud 
som menneskets skaper. Men formår kroppen å vitne om dette guddommelige opphav eller om livet etter døden? Den lyriske diskursen ender negativt: «Hvad vet vi vel om disse ting». Gills blikk er fenomenologisk og spekulerer ikke i det hinsidige. Han er «skolert i fenomenenes sprog», som det heter i et annet dikt.

Neste strofe er mer personlig: «Hvad vet vi vel om dette blikk?» Men blikket kan ikke tydes når det ikke lenger er seende. Hva kan vi vite «foruten det vi ser», står det, altså handler det like mye om vårt eget blikk, slik det møter den dødes øyne. Den dødes blikk har ingen meningsgivende fremtid, men vi aner en fortid som kanskje skjuler selvmordets årsak. I et slikt tilfelle er ikke vårt eget blikk nakent og sterilt. Det er nettopp et levende, intensjonalt blikk, og dermed bærer det med seg de betydninger som har avleiret seg i vårt forhold. Synsinntrykket av avdøde vil veksle mellom kroppens livløshet og våre minner om personlig nærvær. Fortiden hefter ved vennens døde blikk som «et gjenfærdsskjær».

Krigsminner trenger seg på. Elven Adige har sine kilder i de sveitsiske alper og renner ut i Adriaterhavet. Under første verdenskrig var området en del av den italienske fronten. Her døde over to millioner soldater og en halv million sivile. Krigens lidelser går igjen i vennens blikk. Lidelsen gir skinn av å være samtidig. At dette skinnet er vevd inn i virkeligheten, viser seg i selvmordets realitet. Kokainet nevnes i siste linje, et middel til å døyve krigens traumer. Misbruk innebærer økt selvmordsfare, så det «skinn» som rusen gir, den kunstig frembrakte tilstanden, kan med rette karakteriseres som «likhvitt».

Ved å forklare selvmordet på denne måten innordnes det i en forhåndenværende kausalsammenheng. Kanskje er forklaringen riktig, og vi tar krigens lidelser på største alvor, men også i fredelige tider kan et menneske overveldes til selvmord.

\section{Vi hører disse ord}

Diktets «vi» tar ordet, og etter kolon kommer et sitat som representerer den dødes tale. I retorikken er dette kjent som eidolopoiea, en form for ironi, i den grunnleggende betydningen av forstillelse. Diktet presenterer den dødes tale som samtidig tale i førsteperson. Her oppviser diktet et 
høyt refleksjonsnivå: De andre kan ikke forstå den enes egne væren-tildøden. Den kan bare forstås i førsteperson. Diktet får et dialogisk preg, der «vi» slipper til den døde og lar hans stemme lyde på en måte som gir inntrykk av nytt liv. Slik også fortolkningen må la diktets stemme få nytt liv, ifølge Gadamer.

Strofen åpner opp for selvmordet som mulighet, formidlet av det vakre synet av lotusblomsten. Dens symbolikk henger sammen med stilkens oppadstigende bevegelse: fra roten i det mørke mudderet, gjennom vannets dyp og opp mot overflaten som brytes med blomsten. I buddhismen tolkes lotusblomsten som oppvåkning. Men det vakre synet er likevel bare et syn. Skjønnheten makter ikke å heve mennesket over det biologiske nivået, slik blomsten hever seg over vannet. Det skjer intet kvalitativt sprang, bare en kvantitativ metning. For blomster må visne, og det vårhvite går over i høstens mørke. Jorden krever sitt. Neste linje hentyder til dette ved å minne om tidens uavvendelighet. Tiden åpner verden, og autentisk forstått åpner den også for en besinnelse på endeligheten. Mettheten kan potenseres som kvalme. Den som har sett seg mett, orker ikke se mer. En slik desillusjon er nedslående, men peker også mot mulig autentisitet - overtagelse av egen eksistens. I Odysseen kobles lotusdyrkelse til rusmisbruk. Lotofagerne forførte Odyssevs' menn slik at de glemte seg i øyeblikkets nytelse. Allerede synet av lotus kan for en stund få oss til å glemme døden. Skjønnheten anerkjennes, men den løser ikke eksistensens problem.

Neste strofe fortsetter avdødes tale. De tretti årene med krig kan vise til bokstavelig eller metaforisk krig. Den kan være et kynisk bilde på livet eller et hint om den sannhetens strid som eksistensen står i. Vi er kastet inn i verden. Dette begrenser både forståelsen og våre muligheter. Ikke minst er vi belemret med den «giftige formel», den dødens labyrint vi ikke finner ut av. Hvert øyeblikk kan vi velge å ikke fortsette. Den muligheten vet vi om, men den erfares sjelden som reell. Den eksistensen som åpner seg for dødens utfordring, og på dette grunnlaget fortsetter sin væren-i-verden, har forsøkt å gjøre livet til sitt eget, men dette kan være svært krevende. I Einführung in die Metaphysik snakker Heidegger om å bli overveldet av væren. Derværen kan da svare på den volden den overveldes med ved å vende sin egen vold mot seg selv. Dette er den uhyggeligste strategien derværen har til rådighet. Heidegger viser til Ødipus $i$ 
Kolonos av Sofokles, ${ }^{1}$ hvor koret gir uttrykk for at det aller beste er ikke å være født, det nest beste er å dø fortest mulig: «Dette dikteriske ord uttaler det inderligste i Der-væren i dens forhold til Væren og i dens åpning (Eröffnung), hvor det som er fjernest fra væren, nemlig ikke-væren, kan nevnes» (Heidegger, 1953/1983, s. 135).

Selvmordets mulighet hører til det å eksistere, men også livets strid er noe som forgår. Lotusens skjønnhet representerer et idealisert eller estetisert bilde av livet, mens krigen viser oss den materielle, eller naturlige siden. En slik livsvisjon kan virke utmattende og kvalmende. Adverbet «Kanhænde» forekommer tre ganger og gir strofene et formodende preg. Som om den talende forsiktig anfører argumenter for selvmord. Referansen til Adige og krigen leverer grunnlaget for den eksistensielle krigsmetaforikken.

Én linje gjentas: «som ikke er, men engang var». Utsagnet peker utover den dødes tale og utdyper det tidens riss vi har kommentert. Vi aner en positiv konnotasjon: Det er en lettelse at livet er over.

\section{Også vi}

Etter hver av de to strofene med den dødes tale kommer diktets «vi» med kommenterende spørsmål. Medværen trekkes inn i dødens dialog. Hvordan møte vennens selvmordstanker? Spørsmålene dreier seg om skyld og om eksistensiell forståelse. For det er usikkert om våre ord kunne gjort en forskjell. Man kan ikke ta døden fra et menneske. Velmente råd i fortvilelsens stund kan oppfattes som klisjeer fra «das Man». Kastetheten (Geworfenheit) kan ikke oppheves. Ingen har bedt om å komme til denne verden som vi også alle må ut av. Så spørres det etter hva vi ikke kan si: Vennens selvmord kan fortrenges, men forfølger oss som en eksistensiell realitet. Også vi skal dø vår egen død. Disse kommenterende strofene peker mot en besinnelse på dødens ikke-relasjonalitet. At vi skal dø, er et allment forhold som kan kommuniseres til andre. Våre forestillinger om døden er kulturelt preget. Men det er en rest tilbake, og det er den det kommer an på: At jeg skal dø, er ikke en konstruksjon, men en eksistensiell realitet. Selvmorderens skudd etterfølges av vertens utrop. Han vandre med stakket frist / dithen hvorfra du nys er kommet» (Sofokles, 1924, s. 155). 
konstaterer raskt at skuddet var velrettet. Her er det ikke snakk om et nølende forsøk, men om derværens resolutte «vold mot seg selv».

Mot slutten kommer to trelinjede strofer: «Hvad kan vi si og ikke si» er en oppsummering av spørsmålene foran, med alternativene eksplisert. Her dreier det seg også om diktets egen utsigelse og om utfordringen ved å portrettere en avdød ved hjelp av ord. Oppgaven er presisert dithen at portrettet krever å bli stilt fritt. I et estetisk perspektiv har vi her å gjøre med et autonomimotiv. Kunstens autonomi er en forutsetning for dens sannhet. Det frie verket kan fremstille sannheten uten å skjele til oppdragsgiverens interesse. Kunstens strid er en iverksettelse av sannhetens strid. Men om vi tar i betraktning at portrettet her nærmer seg livet selv, og at ditt liv er ditt selvportrett, blir denne strofen en appell om å se den andre som selvstendig intensjonal derværen, som et genuint individ, ikke bare et eksemplar av arten menneske. Derfor har diktet fremstilt vennen i førsteperson, som en eksisterende. Han portretteres ikke ved ytre kjennetegn, men ved å få komme til orde med sine fortvilede tanker. Han portretteres innenfra. Vi har kanskje overdrevet det logisk-argumentative ved avdødes diskurs, som om selvmordet var konklusjonen på en bevisprosedyre, men stemningen veier like tungt. Hvordan vennen befinner seg, er like viktig som argumentenes beviskraft. Følelser kan vanskelig omsettes i ord, men fortvilelsen over å være overveldet kan gjenkjennes i den rystelsen diktet formidler til den dvelende lesningen - som føyer seg etter det Gadamer kaller kunstverkets egentid. Slik at også den komplekse og opprevne formen får virke.

I diktet refererer «vi» til den levende menneskehet, mens «jeg» er den døde. Han kretses forsiktig inn. Ordene som høres, kan forstås som den dødes tale, slik ordene huskes og gjenoppvekkes ved hjelp av diktets resonans. Avgjørelsen om selvmord fremstilles på avdødes egne premisser. Dermed blir hans tale foruroligende. Oppmerksomheten om krigstraumer og påfølgende rusmisbruk har en samfunnskritisk gehalt. Diktet er et vitne om hvordan krig kan selvmyrde de overlevende. Men den avdødes ord viser til et eksistensielt sjikt som enhver leser bør ta innover seg. Diktet er et eksistensielt lærestykke. Krigstraumene har kanskje forstyrret den beroligende uegentlighet vi er avhengige av for å kunne befinne oss vel. Den folkerettslige krigen kan sammenlignes med den strid eksistensen står i: derværens strid når den overveldes av væren. 
Innledningsvis var vi innom kritikken mot Heideggers dødsfilosofi. Gjennomgangen av Gills dikt gjør det mulig å belyse begrepet om ikke-relasjonalitet på en måte som også viser dets berettigelse. Selv om vi har erfart at andre mennesker dør, betyr ikke det at døden som sådan er sosialt formidlet. Slik eksistensen er min, så er også døden min egen. Folk kan gå i døden for meg, men ingen andre kan dø min død. Forholdet mellom døden og medværen må forstås på en annen måte: Derværen er medværen. Vi er grunnleggende sammen med de andre som kan opptre som «das Man». Dette er beroligende og oppbyggelig, men det fjerner oss fra oss selv. I angsten rives eksistensen bort fra «das Man» og støtes tilbake på seg selv. Medværen settes ikke ut av funksjon, men får en dypere innebyrd. For vi deler de eksistensielle vilkårene. Derfor kan vi være der for den andre, ikke ved at vi bortforklarer eller adspreder, men i kraft av at vi selv vet hva det dreier seg om. Når vi selv har erfart at den ene må dø sin egen død, og at den er hans mest egne mulighet, bare da kan vi være der for vår venn. Dette er eksistensielle realiteter som kan erfares av den enkelte. Døden kan ikke reduseres til sosial overlevering eller kulturelle konstruksjoner. Heidegger danner en motpol til sivilisasjonsteoretikeren Norbert Elias, som i sin bok om De døendes ensomhet argumenterer for å ufarliggjøre døden ved hjelp av medisinske fremskritt og moderne opplysning. Han ignorerer avgrunnen mellom den enkeltes eksistens og den kollektive overlevering:

Døden skjuler ingen hemmelighet. Den åpner ingen dør. Den er slutten på et menneskeliv. Det som overlever mennesket, er hva det har gitt til andre og som forblir i erindring. (Elias, 1984, s. 95)

Elias var en gammel mann da han skrev denne boken. Kanskje har arbeidet vært en form for terapi. Filosofisk minner han om Epikur, som forsøkte å fjerne dødsangsten på lignende vis. En hovedsak for Elias er å avhjelpe den ensomheten mange føler i møtet med døden. Her tror jeg nok Heidegger ville sagt at det dreier seg ikke så mye om å frykte døden som å ta innover seg at den innebærer slutten. Dersom vi mister dødens alvor, mister vi også livet. Elias er derfor en representant for «das Man». Veien til en forståelse av døden må gå gjennom ensomheten. Innledningsvis tok vi opp Gadamers hermeneutikk og hans tanker om kontinuitet. Den hermeneutiske praksis innebærer en omgang med de døde som 
stadig minner oss om at døden er vårt felles vilkår, men som også viser hvordan døde skrifttegn kan våkne til nytt liv i vår egen tenkning, i vår egen skrift, også når de er viet døden.

\section{Referanser}

Benjamin, Walter (2014). Skrifter i utvalg [I]. Arild Linneberg (Red.). Oslo:

Vidarforlaget. Den siterte teksten er oversatt av Arild Linneberg.

Elias, Norbert (1984). De døendes ensomhet. Oversatt av Niels Magnus Bugge. Oslo: Pax forlag.

Gadamer, Hans-Georg (2010). Sannhet og metode. Oversatt av Lars Holm-Hansen. Oslo: Pax forlag.

Gadamer, Hans-Georg (1977). Aktualitet des Schönen - Kunst als Spiel, Symbol und Fest. Stuttgart: Reclam.

Gadamer, Hans-Georg (u.å.). Konst som spel, symbol och fest. Oversatt av Pehr Sällström. Ludvika: Dualis Förlag.

Gill, Claes (1939). Fragment av et magisk liv. Oslo: Cappelen.

Gill, Claes (1995). Samlede dikt. Etterord ved Henning Hagerup. Oslo: Cappelen.

Hakola, Outi, Heinämaa, Sara, \& Pihlström, Sami (Red.) (2015). Death and

Mortality: From Individual to Communal Perspectives. Helsinki: Helsinki

Collegium for Advanced Studies.

Heidegger, Martin (1927/2007). Veren og tid. Oversatt av Lars Holm-Hansen. Oslo: Pax forlag.

Heidegger, Martin (1950/200oa). Kunstverkets opprinnelse. Oversatt av Einar Øverenget. Oslo: Pax forlag.

Heidegger, Martin (1953/1983): Einführung in die Metaphysik. Gesamtausgabe bd. 40, Frankfurt am Main: Vittorio Klostermann.

Heidegger, Martin (20oob). Introduction to Metaphysics. Oversatt av Gregory Fried \& Richard Polt. New Haven \& London: Yale University Press.

Heinämaa, Sara (2015). The Many Senses of Death: Phenomenological Insights into Human Death. I Outi Hakola et al. (Red.), Death and Mortality: From Individual to Communal Perspectives. Helsinki: Helsinki Collegium for Advanced Studies.

Sapfo (2005). «Nytt Sapfo-dikt», oversettelse ved Svein Jarvoll, Morgenbladet, 5. august 2005.

Sofokles (1959). Tragedier. Oversettelse ved Peter Østbye. Oslo: Gyldendal.

Songe-Møller, Vigdis (2012). Heidegger og den andres død. Norsk Filosofisk Tidsskrift 47(4), 245-258. Oslo: Universitetsforlaget.

Symons, Arthur (1974). Selected Writings. Roger Victor Holdsworth (Red.). London: Fyfeld Books/Carcanet. 

KAPITTEL 8

\title{
Jeg steg inn i en annen historie. Om Simone de Beauvoirs bok En lett og rolig død
}

\author{
Lisbeth Thoresen og Hilde Bondevik \\ Universitetet i Oslo
}

\begin{abstract}
Summary: Death is a common theme in the writings of Simone de Beauvoir (1908-1986), and in her small book A very easy death from 1964, she describes the deathbed of her mother, Françoise de Beauvoir (1885-1963). In reading this very personal and touching story, we become aware of how death is described as taboo and handled as something shameful and silenced, by the health care professionals at the hospital as well as by Beauvoir and her sister, Hélène. The dying mother has not been informed that she has cancer, and she dies while being served another lie. A very easy death mirrors contemporary attitudes and practices in French middle class end-of-life care in the 1960s, but these are also common approaches to dying and death in other Western countries at that time. The book can also be read as a critique of the strong medical regime and lack of a more compassionate and open end-of-life care. In today's Norwegian health care service, most cancer patients receive palliative care at the end of life, which means good palliation of pain and other symptoms. An important aspect of palliative care is that patients shall be informed about and involved in decisions regarding care and treatment. Even if the dying process can be softened in some ways, it seems like dying and death continue to challenge and shake us, as it did to Beauvoir. Being at the deathbed was an opportunity to talk about it, but as far as we know, Simone de Beauvoir remained silent on this topic. Even today we regard $A$ very easy death as an invitation to talk about dying and death.
\end{abstract}

Keywords: Simone de Beauvoir, cancer, death, literature, phenomenology

\begin{abstract}
«Hun hvilte og drømte, i en uendelig avstand fra sin råtnende kropp, med ørene fulle av støyen fra våre løgner og fullstendig samlet om et drømmende håp: å bli frisk.»
\end{abstract}

(Beauvoir, 2000 s. 69)

Sitering av denne artikkelen: Thoresen, L., \& Bondevik, H. (2018). Jeg steg inn i en annen historie. Om Simone de Beauvoirs bok En lett og rolig død. I A. Johannessen, N. Askeland, I. B. Jørgensen. \& J. Ulvestad (Red.), Døden i livet (Kap. 8, s. 137-152). Oslo: Cappelen Damm Akademisk. https://doi.org/10.23865/ noasp.40.ch8

Lisens: CC BY-NC 4.0 
Døden er et gjennomgangstema i den franske forfatteren og filosofen Simone de Beauvoirs (1908-1986) forfatterskap. Fra hun var ganske ung fryktet Beauvoir døden, og omtalte den som et radikalt fravær og en skandale. I Moden alder (Beauvoir, 1960/2004) skriver hun eksempelvis at døden skremte henne så snart hun forsto at hun var dødelig (s. 575). Mye tyder på at hun fortrengte frykten eller i det minste unnlot å tale om den som ung. Krigen ble i så måte en vekker. «Aldri», skriver Beauvoir, «hadde min egen død og de andres død opptatt meg på en så påtrengende måte som i disse årene. Det er på tide å snakke om det» (s. 575). Og hennes roman Alle mennesker er dødelige (1946) kan fremfor alt sies å være et langt streiftog mot døden. Om denne teksten sier hun selv at hun forsøker å rette opp den moralske optimismen fra sine to foregående verker gjennom nettopp å beskrive døden (Beauvoir, 2004, s. 582). Det er talende for Beauvoirs livsholdning at hun betrakter eksistensen som grunnleggende tvetydig, noe essayet Alderdommen (1970/2016) illustrerer til fulle. Hun preges av både intens livsglede og dødsangst.

Grunntonen hos Beauvoir er med andre ord pessimistisk og dypt eksistensialistisk. Det er nettopp denne vi igjen møter i hennes både svært personlige og erfaringsnære tekst om morens, Françoises, dødsleie, En lett og rolig død (Beauvoir, 1964/200o). I forordet til den norske utgaven skriver Bente Christensen, som har oversatt boka fra fransk, at Beauvoirs private erfaringer fra sin mors syke- og dødsleie er allmennmenneskelige. Til tross for at morens død skjer innenfor rammene av fransk helsevesen på 1950-tallet $\mathrm{og}$ av datidens medisinske kunnskap, syn på pasienten, religion og middelklassekultur for øvrig, vekker historien som fortelles, gjenklang hos dagens lesere. En lett og rolig død illustrerer noen fellesmenneskelige følelser og erfaringer - den beveger og berører fremdeles. I dette kapitlet tar vi utgangspunkt i Beauvoirs selvbiografiske bok og undersøker hvordan hun gjennom sin erfaring forstår og forholder seg til døden. Vår oppfatning er at hennes beskrivelser og skjønnlitterære tekst kan være en inngang til å forstå noen av de eksistensielle og allmennmenneskelige sidene ved døden i dag, femti år senere, og i en norsk kontekst. Vi spør: Hvordan beskriver Simone de Beauvoir sine egne erfaringer og opplevelser av morens dødsleie? Og hvordan kan En lett og rolig død fungere som en inngang til å reflektere rundt vår tids holdninger og praksiser rundt døden? 
Vår lesning er ledet av en oppmerksomhet rundt detaljene i teksten, en nærlesning som forsøker å ta høyde både for Beauvoirs særegne erfaringer, slik hun selv beskriver dem, og for det vi mener berører noen fellesmenneskelige, eksistensielle dimensjoner. Lesningen kan også sies å ha en tematisk inngang, idet noen temaer og detaljer har vært mer sentrale enn andre. Av særlig interesse for oss, og som følgelig får betydning for vår oppmerksomhet, er døden som et taust og tabubelagt fenomen. Et sentralt tema blir betydningen av løgnen og forstillelsen Beauvoir skriver frem. En slik tematisk lesning tar gjerne også hensyn til den litterære tekstens sosiale cogito, det vil si de historiske og idéhistoriske horisontene den var en del av og videre peker frem mot. Slik utgjør de kontekstuelle rammene teksten er skrevet innenfor, også et anliggende for oss og bidrar til at vi kan tolke Beauvoirs tekst inn i en samfunnskritisk sammenheng, noe vi diskuterer avslutningsvis. Vi har søkt å være tett på Beauvoirs tekst, samtidig som vi diskuterer den i relasjon til enkelte av hennes andre arbeider samt andre betydningsfulle idéhistoriske og kultursosiologiske arbeider om døden.

\section{Om En lett og rolig død}

En lett og rolig død kan betraktes som en memoartekst. Det er Simone de Beauvoirs egne erindringer, hennes personlige erfaringer og refleksjoner rundt morens død vi kan lese om. Slike memoarer må skilles fra dagboksnotater, som gjerne skrives ned samtidig som hendelsene det er snakk om, skjer. Hendelsene i boka er nedskrevet i perioden etter morens død, noen dager etter begravelsen, slik Beauvoir retrospektivt erindrer hendelsesforløpet og sine egne følelsesmessige reaksjoner. Det er en innsiktsfull og følsom tekst, men den er også urovekkende og utfordrende. Ifølge Toril Mois bok om Beauvoir, demonstrer En lett og rolig død også hennes evne til å formidle - og overvinne - sorgen gjennom skriften (Moi, 1995, s. 280). Vi gjenkjenner både hennes eksistensialistiske orientering og hennes fenomenologiske forankring i teksten: Hun er tett på egen erfaring, situasjonen og meningsaspektene i livet - på valg, løgn, tap, ensomhet, angst, tid, det kroppslige og altså død.

En lett og rolig død er en liten bok. De snaue hundre sidene kan man lese på én kveld, noe som bidrar til en fortettet leseropplevelse. 
Handlingen i boka spenner over et tidsrom på noen uker, fra moren blir innlagt på sykehus og til hun dør. Det er Beauvoir som er fortellingens jeg. Som et bakteppe til sykehistorie og død er morens biografi et tema i boka. Beskrivelsen av hennes barndom, ungdomsår, ekteskap, lykke og ulykke fyller ut bildet av den svært syke og sengebundne kvinnen vi blir kjent med. Beauvoir omtaler foreldrene som mamma og pappa, og det gis ganske nærgående skildringer av disse to, deres samliv og forholdet mellom særlig mor og døtrene Simone og Hélène - eller Poupette, som hun ble kalt. De biografiske detaljene og nærheten gjør at fortellingen fremstår som troverdig, men også personlig og intim. Beauvoir beskriver altså morens dødsleie gjennom sin egen opplevelse av den, usentimentalt. Slik utgjør denne teksten en personlig stemme og illustrerer en helt annen type diskurs enn den vi møter i medisinske og helsefaglige bøker om døden, eller i informasjonsmateriale og offentlige dokumenter. Men samtidig kan boka også leses som en pamflett, som en etisk og politisk oppfordring til mer åpenhet rundt sykdom og død, og ikke minst som en kritikk av fransk helsevesen anno 1950, av dens praksis rundt alvorlig syke og døende pasienter.

\section{Dødens historie}

Boka begynner med nøyaktig steds- og tidsangivelse for hvor Beauvoir var da hun fikk oppringning med beskjed om at moren hadde falt og var innlagt på sykehus. Også andre steder i boka bidrar liknende opplysninger til å sette morens sykeleie og det som skulle vise seg å være hennes siste tid, inn i en konkret historisk periode og en samfunnsmessig og kulturell kontekst. En person som særlig har bidratt til å gjøre oss oppmerksomme på at handlinger og holdninger til døden må forstås i lys av sin samtid, er en landsmann av Beauvoir, den franske filosofen Philippe Ariès (1918-1984). Hans bøker (Ariès, 1976, 1981, 1985) regnes som standardverk når det gjelder å beskrive hvordan kollektive oppfatninger og holdninger til døden har endret seg betydelig i den vestlige del av verden gjennom århundrene. Ariès (1976) identifiserer fire faser eller perioder i dødens historie som spenner fra middelalderen og frem til det 20. århundre: den temmede døden, min død, din død og den forbudte døden. 
Karakteristisk for de tre første historiske periodene er samfunnets fortrolighet med døden, bevisstheten om at døden er uunngåelig, og at døden forstås og gis mening som del av en større religiøs horisont. Skiftene i synet på døden har skjedd så langsomt at de knapt har vært merkbare gjennom århundrene, men den perioden Ariès omtaler som den forbudte døden, karakteriseres av nokså brå og store endringer, nærmest av å være en revolusjon. Fra begynnelsen av 1900-tallet blir døden borte fra det alminnelige hverdagslivet og det offentlige rom. Den flytter inn på sykehuset, og forbindes der med medisinsk nederlag, skam og forlegenhet. Den danske sosiologen Michael Hviid Jacobsen (2009) omtaler dette som dødens store forsvinningsnummer.

Det er sin egen samtid Ariès definerer som dødsfornektende, og det er innenfor denne fasen av dødens historie fortellingen om Beauvoirs mor finner sted. Gjennom å være tett på Beauvoirs fortelling vil vi vise hvordan den rådende mentaliteten, de forestillingene og den praksisen som Ariès beskriver som karakteristisk for den forbudte døden, til fulle er til stede ved morens dødsleie. I tillegg vil vi vise hvordan Beauvoir reflekterer over og problematiserer sine egne tanker, reaksjoner og handlinger.

\section{Begynnelsen på slutten}

Beauvoir befant seg i Roma da telefonen kom en oktoberdag i 1964. Moren hadde falt hjemme i sin egen leilighet, og hun ble deretter innlagt på en akuttavdeling. Man antok at hun hadde brukket lårhalsen. Beauvoir dro til Paris straks hun hadde fått vite hva som hadde skjedd. Samme kveld besøkte hun sin mor, og fikk beskjed om at det likevel ikke var et lårhalsbrudd, og at tre måneders hvile var det som skulle til. Moren hadde hatt vondt i magen tidligere, og en lege sa han ville la moren gjennomgå noen undersøkelser. Beauvoir skriver: «Jeg kom ikke før tirsdag morgen. Jeg skjøv opp døren og stivnet der jeg sto. Mamma, som fra før var mager, syntes nå å ha blitt enda magrere og mer sammenskrumpet: hun var sprukken og uttørret og liknet på en rosafarget druestengel. Ansiktet hennes var falt sammen, det var fortrukket og ulykkelig» (s. 26). Samme kveld ble Beauvoir oppringt av en lege ved klinikken som fortalte at moren ikke var bra, og at Beauvoir burde komme tidlig neste morgen. Samtalen 
ble avsluttet med at det var funnet en svulst som blokkerte tynntarmen. «Kreft. Det hadde ligget i luften. Det var til og med slående tydelig: De blå ringene, magerheten» (s. 26).

\section{På hospitalet}

Beauvoir ble oppringt på ny neste morgen med beskjed om at moren hadde kastet opp hele natten og neppe ville overleve dagen. Sammen med søsteren Poupette blir hun informert når de kommer til klinikken om at en narkoselege skulle tømme morens mage ved hjelp av en sonde gjennom nesen. «Men hva er det godt for å plage henne dersom hun er dømt? Bare de kunne la henne dø i fred og ro, sa Poupette gråtende til meg» (s. 27). Beauvoir spør legen om sonden, om den virkelig er nødvendig. «Hvorfor torturere mamma når det ikke lenger er håp?» (s. 28). Legen, doktor N, omtales som «en ung mann med lukket ansikt, i hvit frakk og hvit kalott» (s. 28). Han svarte at han gjør det han må gjøre, og at han har reddet henne.

Beauvoir forteller at hun ikke våget å spørre ham «til hva?» (s. 28). Moren hennes blir liggende på rommet sitt med intravenøst drypp og en sonde ut fra nesen og ned i en beholder med gulaktig materie. «Neseborene hennes var sammentrukne, ansiktet var blitt enda mer innskrumpet; det hadde et uttrykk av fortvilet lydighet» (s. 28). Beauvoir beskriver hvordan legene vurderte operasjon, men var usikre fordi moren var så svak. En sykepleier sa til Beauvoir: «Ikke la henne opereres! Hvis doktor $\mathrm{N}$ visste at jeg har sagt dette til dem! Jeg snakker som om det dreide seg om min egen mor» (s. 29). Operasjon ble planlagt, men moren til Beauvoir ble ikke informert om denne. Hun ble i stedet fortalt at hun skulle ta noen røntgenbilder, og at hun skulle få en beroligende sprøyte i forkant. Det skjer, og hun ble trillet inn til operasjon og ikke til røntgenundersøkelser. «En time senere var Poupette i telefonen: Kom straks. De har åpnet magen; de har funnet en enorm svulst, ondartet. [...] Halsen min snørte seg av frykt. [...] Vi spurte oss selv hva vi skulle si til mamma når hun våknet. Det var enkelt: røntgenbildene hadde vist at hun hadde bukhinnebetennelse, og de hadde straks besluttet å operere henne» (s. 29-30). Beauvoir beskriver legen, dr. Ns stolthet over å ha reddet 
morens liv, takket være moderne teknikk og narkosemetoder. Beauvoir deler ikke gleden, hun er dypt fortvilet. Hun gråter og sørger, ukontrollerbart. Hun skriver at hun mangler kontroll over gråten fordi en annen gråter i henne: moren. Det er morens ensomhet i livet og i døden som river i henne, en ensomhet «som ikke måtte innrømmes» (s. 31).

\section{Løsrevet fra livsverdenen}

Rammen for fortellingen om morens død er altså sykehuset på 1960tallet. Gjennom Beauvoirs tekst blir det slående tydelig hvordan det er sykehusets og den kliniske tenkningens logikk som legger premissene og som styrer, nokså autoritært og paternalistisk, morens siste tid. Legene ser ut til å drives nærmest av en handlingstvang: De gjør det de må gjøre, og gjennom det de gjør, mener de at de redder moren. Dr. N legger en sonde ned i morens mage, og han tar beslutningen om operasjon. Døden bekjempes eller utsettes ved at den døende pasienten blir underlagt det arsenal av behandling og medisinskteknisk utstyr som var tilgjengelig, slik at Beauvoirs mor blir «lenket» til sonder, sug og kanyler. Men hvorfor en slik pågåenhet overfor en alvorlig syk og svekket gammel kvinne? Hvorfor ikke la døden komme?

Hviid Jacobsen (2009) peker på ulike forklaringer på at døden gikk fra å være en naturlig og fortrolig del av (familie)livet til noe som ble fremmed og vanskelig å akseptere utover på 1900-tallet, også for legene. Den medisinske kunnskapsutviklingen bidro til en generell optimisme når det gjaldt hva medisinsk behandling kunne utrette, og det fremste målet for behandlingen var tilfriskning. Døden ble derfor oppfattet som et nederlag og noe man forsøkte å holde unna. Ariès (1976) hevder at mens den døende i tidligere tider var midtpunktet i dødsprosessen, omgitt av familie og kjente, har legene og de andre ansatte på sykehuset blitt «the masters of death» (s. 89). Når døden blir til et medisinsk og teknisk anliggende, dekonstrueres døden, ifølge den polsk-engelske sosiologen Zygmunt Bauman, den mister mening. Til tross for alle fremskritt representerer døden på denne tiden det som fremdeles ikke kan kontrolleres. Den blir uttrykk for det man ikke lykkes med, den oppfattes som en feiltagelse eller skandale (Hviid Jacobsen, 2009). Å forstå den aktive 
og nærmest pågående behandlingen som Beauvoirs mor underlegges, i lys av disse tenkemåtene, gir mening, slik vi ser det. Følgene av at døden blir forsøkt overvunnet, er at den ikke lenger blir anerkjent som en del av livet. I stedet fornektes og forties den.

\section{Den forferdelige hemmeligheten}

At det var en dødskamp moren gjennomlevde, var først og fremst kjent for legene og for den nærmeste familien. Når Beauvoirs søster Poupette spør legen hva de skal si til moren når sykdommen blusser opp igjen, er svaret at hun ikke skal være urolig: «Vi skal finne på noe. Vi finner bestandig på noe. Og den syke tror bestandig på det» (s. 44). Moren, som ifølge Beauvoir tror hun skal bli frisk igjen, uttrykker derfor overraskelse da Poupette sier at hun vil sove hos henne. Moren gir uttrykk for at hun føler seg svak, og hun ønsker å unngå enhver anstrengelse. Derfor erklærer hun at hun ikke vil spise mer, og at hun vil klippe håret sitt kort. Smerter gjør at hun helst vil gjøre fra seg rett i lakenet, og slippe å bli løftet opp på et bekken. Moren får sprøyter for å motvirke plager av urinstoff. Sprøyten omtales som smertefull, og moren virker så plaget at sykepleieren nøler med å sette den. «Gjør det, sa mamma, siden det er bra for meg» (s. 51). Beauvoir omtaler løgnen som får moren til å gjøre det som hun tror er bra for henne, som «den forferdelige hemmeligheten» (s. 50), og uttrykker at hun har lyst til å be en eller annen om forlatelse (s. 51).

Moren plages av sitt eget endrede utseende, men også av alt det smertefulle og plagsomme hun må gjennom. Å få en ny veneflon (nål inn i en blodåre) er vondt og gjør at den ene armen svulmer opp. Beauvoir skriver: «Om kvelden ble hun grepet av angst: hun var redd for natten, for et nytt uhell, for smerten. Med sammentrukket ansikt tryglet hun: pass godt på dryppet! Og denne kvelden spurte jeg meg selv på nytt, mens jeg betraktet armen hennes hvor det rant inn liv som ikke lenger var annet enn ubehag og plage: hvorfor?» (s. 52).

Beauvoir bebreider seg selv at hun ikke har hindret at moren ble operert, og hun omtaler bebreidelsen som en kreftsvulst som tærer henne. Hun mener hun har sviktet sin egen moral, men (Jean-Paul) Sartre, hennes livsledsager gjennom mange år, sier henne imot. Det er ikke moralen, 
men teknikken som har vunnet over Simone, mener han - teknikken og spesialistene. At det er slik, viser seg i hvordan Beauvoir ikke våger å opponere mer mot legenes beslutninger enn det hun gjør. Hun ønsket å be om at de skulle la moren være i fred, la henne dø, men hun visste at hun ville møte motstand fordi legene ville vise til muligheten for at moren ville leve videre - «Og jeg ville være nødt til å gi etter» (s. 53). Beauvoir fortviler og bebreider seg selv:

Og selv om døden vant, for et avskyelig bedrag! Mamma trodde at vi var sammen med henne, men vi befant oss allerede på den andre siden av hennes historie. Lik en ondskapsfull, allvitende demon, kjente jeg baksiden av kortene, og hun sloss langt borte, i menneskenes ensomhet. Hennes hårdnakkede kamp for å bli frisk, hennes tålmodighet, hennes mot, alle kortene var merket. Hun ville ikke få gevinst på noen av sine lidelser. Jeg så igjen for meg ansiktet hennes: «Siden det er bra for meg.» Jeg led fortvilet over en feil jeg hadde begått uten å kunne noe for det, en feil jeg aldri kunne gjøre god igjen. (s. 54)

\section{Å stige inn i en annen historie}

Etter morens operasjon blir noe dramatisk endret. Beauvoir skriver om hvordan det erfares som å stige inn i en annen historie da hun kom tilbake til klinikken. Omgivelsene der trer frem for Beauvoir på andre måter, de blir mer tydelig og beskrivelsene mer inngående. Rekonvalesens og normalitet var avløst av dødskamp og tragedie. Beauvoirs beskrivelser av morens sykeleie er sterk kost. Hun sparer ikke leseren for noen detaljer, tvert om leser vi om de mest intime og personlige situasjoner. Beauvoir deler sine observasjoner av hvordan morens kropp brytes ned og endres; hun beskriver lukter og utsondringer, smertefulle prosedyrer, men også ansiktsuttrykk og stemninger. På én måte står den konkrete og detaljrike fortellingen og alt som legges frem for leseren, i kontrast til det som ikke snakkes om mellom moren, døtrene og legene de ukene morens sykeleie varer. Som leser får man vite alt. For hovedpersonen i boka holdes sannheten tilbake. Kreftdiagnosen er dramatisk, og behandlingen er smertefull og en stor påkjenning. Likevel leser vi fortielse og løgn som det mest sentrale og gjennomgripende temaet i Beauvoirs bok. Moren blir ikke på 
noe tidspunkt informert om at hun har kreft, og at hun har kort forventet levetid. Tvert om blir hun servert den ene usannheten etter den andre, både av legene og av sine nærmeste pårørende, døtrene. Beauvoir, som ellers fremstår som en meget verbal og modig kvinne, våger ikke å utfordre legenes beslutninger, og moren på sin side uttrykker ifølge Beauvoir en fortvilet lydighet. En sykepleier forsøker riktignok å hjelpe Beauvoir til å motsi legene, men på en måte som viser at også hun er underlagt autoritære krefter. Tatt i betraktning at etikk og mellommenneskelige relasjoner omtales som sentrale temaer i Beauvoirs filosofi og forfatterskap (Gothlin i Rustad \& Bondevik, 1999), er dette særlig interessant, og trolig også en medvirkende grunn til at Beauvoir hadde så sterkt behov for å skrive denne boka. Hvilke mentaliteter, forestillinger og diskurser gjorde løgnen til nærmest en dyd og en selvsagt handling i fransk helsevesen på 1960-tallet?

\section{Skal pasienten få vite sannheten?}

Spørsmålet om pasienten skal få vite sannheten om sykdommen og prognosene, er beskrevet som kjente dilemmaer. Susanne Malchau (1993), som har studert sykepleie til døende i Danmark i perioden 1926-1965, viser at dette spørsmålet har vært kilde til stor uenighet mellom (mannlige) leger og (kvinnelige) sykepleiere. Legenes syn var sterkt influert av forestillinger om at døden var et nederlag, og at pasientene ikke tålte å få høre sannheten. Sykepleierne var ikke enige, og mente at pasientene burde få vite hvordan det stod til, men på en skånsom måte. På den måten kunne pasienten forberede seg «både materielt og åndelig» (s. 113). Ariès (1976) hevder at legenes motivasjon for fortielsen var hensynet til den syke, og at samfunnet skulle spares for den emosjonelle belastningen som «the ugliness of dying» (s. 87) medførte. Basert på en klassisk feltstudie fra amerikanske sykehusavdelinger, publisert i 1965 under tittelen Awareness of dying, finner sosiologene Barney Glaser og Anselm Strauss (1965) at nettopp graden av åpenhet omkring den nær forestående døden er nøkkelen til å forstå samhandlingen mellom pasient, pårørende og helsepersonell. Forfatterne skiller mellom fire ulike former for åpenhet: open awareness, suspicion awareness, mutual pretence og closed awareness. Den 
siste typen innebærer at pasienten ikke er klar over at hun skal dø, og Glaser og Strauss beskriver flere strategier leger og sykepleiere tar i bruk for å holde denne sannheten borte fra pasienten. Praksisen med å tie eller lyve ser ut til å ha vært en typisk væremåte og strategi i møte med døende pasienter på denne tiden. Beauvoir beskriver dette som en kamp som hun selv er en del av. Hun anklager og bebreider seg selv for løgner, fortielser og halvsannheter - og for ikke å gripe sjansene som byr seg til en ærlig samtale med moren.

\section{Det siste spillet}

Beauvoir finner moren forandret når hun kommer tilbake fra en liten reise. Moren er gul og hoven i ansiktet. Poupette har kvelden før stanset en blodtransfusjon fordi det var så smertefullt. Doktor $\mathrm{N}$ hadde vært rasende. Dagene går, og morens tilstand svinger mellom relativt gode og marerittaktige dager. Beauvoir beskriver hvordan hun venner seg til denne tilværelsen. Verden utenfor morens værelse mister betydning. Den fremstår som en scene, og Beauvoir omtaler sin virkelighet som der moren befinner seg. Selv om Beauvoir skriver om dette som sin virkelighet, er det et spill som foregår, en komedie: «Med de solbrillene likner du Greta Garbo! Men tungen føltes råtten i munnen min. Jeg hadde følelsen av å spille komedie overalt» (s. 67). Beauvoir forteller hvordan moren tolker det at begge døtrene er hos henne, som et tegn på at hun er blitt dårligere. Også denne anledningen til å fortelle moren sannheten lar døtrene passere: «vi tvang henne til å tie stille med sin uro, til å fortrenge sin tvil: hun følte seg på en gang - som så ofte i sitt liv - skyldig og uforstått. Men vi hadde ikke noe valg: håp var det hun trengte mest» (s. 6o). Moren kjemper med døden, men uten å vite det selv:

Jeg betraktet henne. Der var hun, nærværende, bevisst og fullstendig uvitende om den historien hun levde. Det er normalt å ikke vite hva som foregår under huden. Men til og med utsiden av kroppen hennes unnslapp henne: magen med såret, åpningen, avfallet som rant ut av den, den blå hudfargen, væsken som trakk ut av porene; hun kunne ikke utforske den med hendene, for de var nesten lammet, og når hun ble stelt, la hun hodet bakover. Hun hadde ikke bedt 
om speil flere ganger; det døende ansiktet eksisterte ikke lenger for henne. Hun hvilte og drømte, i en uendelig avstand fra sin råtnende kropp, med ørene fulle av støyen fra våre løgner og fullstendig samlet om et brennende håp: å bli frisk. (s. 69)

Beauvoir og søsteren Poupette blir vitne til morens grusomme smerte, den råtnende kroppen, stanken, liggesårene. De siste dagene får hun jevnlig morfin og beroligende medisiner. Hun dør en natt mens Poupette er der. Beauvoir blir ringt etter, men rekker ikke frem. Poupette har opplevd morens siste timer som grusomme. Hun sier til søsteren at legene hadde sagt at moren ville slukne som et lys: «...det var ikke slik, ikke i det hele tatt, sa min søster hulkende. - Men frue, svarte nattevakten, jeg forsikrer Dem at det var en lett og rolig død» (s. 78).

Det kan se ut som om «spillet» omkring morens dødsleie fortsetter også etter at hun er død. Til tross for alle åpenbare symptomer og tegn på at moren har smerter og kjenner angst helt til det siste, forsikres Poupette om det motsatte - at moren døde lett og rolig. Utsagnet er antagelig ment som trøst, men for oss lesere befestes inntrykket av at den franske klinikken verken har rom eller språk for dødens smerte, uro og heslighet. Nattevakten vil liksom ikke akseptere eller anerkjenne morens angstfylte møte med døden. Like urovekkende kjennes det å lese at selv om begge søstrene uttrykker fortvilelse over alt hva moren må gjennomgå til ingen nytte, bidrar de begge - helt inn i døden - til å opprettholde løgnen, eller til å holde tilbake sannheten. Like før moren dør «... mumlet hun med en stemme som var litt uklar: Dere må holde tilbake dø-sen - Må vi holde tilbake døren? - Nei, sa mamma. Døden. Hun la spesielt trykk på ordet: døden. Hun la til: jeg vil ikke dø. - Men du er frisk! (svarte Poupette)» (s. 78). Kort tid etter dør hun.

\section{Dødens ensomhet}

Boka slutter ikke der, med morens død. Beauvoir beskriver videre det praktiske som måtte ordnes, men ikke minst forsøker hun i en etterrefleksjon å forstå hva som skjedde disse tretti dagene morens syke- og dødsleie varte. Hun stiller spørsmål om hvorfor hun ble så forferdelig rystet over morens død (s. 91), hun spør igjen om det var riktig med intensiv 
behandling og operasjon (s. 83), og hun forundres over hvorfor moren, hvis «[...] religionen var krumtappen og selve innholdet i livet hennes» (s. 8o), ikke ba om å få snakke med en prest. I disse refleksjonene fremkommer det at redselen for døden var noe Beauvoir hadde til felles med moren. Den redselen var så stor at religionen ikke kunne hjelpe, skriver Beauvoir. Men var hun og Poupette til noe hjelp? Bidro de to til å lindre? Ja, mener Beauvoir. Ja, fordi de stilte opp og var der sammen med henne. Moren slapp å ligge alene hos «udyrene», hun slapp å «øle seg som en forsvarsløs ting, fullstendig i hendene på likegyldige leger og overarbeidede sykepleiersker» (s. 84). De hvite løgnene som søstrene fortalte moren, fylte «den tause intetheten». Likevel må Beauvoir medgi at løgnen holdt de to fra hverandre, og bidro til dødens ensomhet.

\section{En lett og rolig død - en modernitetskritikk?}

Françoise de Beauvoir døde i 1963, og boka kom ut året etter. Beauvoirs beretning om morens død svarer langt på vei til karakteristika ved den forbudte døden. Ariès (1976) er meget kritisk til hvordan døende tas hånd om i sin samtid. Mye av kritikken, og særlig mot sykehusenes praksis på dette området, fanges opp av den gryende hospicebevegelsen, med den engelske legen Cicely Saunders i spissen. Hun publiserte på 1960-tallet flere artikler og bokkapitler hvor nettopp pasientfortellinger fikk en fremtredende rolle; «[...] bringing the intense human expression of suffering to clinical audience» (Saunders \& Clark, 2006, s. xv). Selv om sjangrene er ulike, bidrar både Beauvoirs selvbiografiske bok og Saunders' beskrivelser av møter med enkeltmennesker til å konkretisere, situere og nyansere hva som står på spill. Begge bidrar til at døden får ansikt og kropp, den blir relatert til bestemte personer og hendelser. Selv om Saunders var lege, utviklet hun et nært forhold til enkelte pasienter, til og med kjærlighetsforhold. Som Beauvoir ble Saunders derfor «rammet» av - og erfarte sterkt - hvordan døden er et så til de grader rystende sosialt og relasjonelt fenomen. Fremveksten av hospice er en del av den eller de strømningene man refererer til som «death awareness movement», «naturlig død-bevegelsen» og «thanatologibevegelsen» (Graven, Lund \& Hviid Jacobsen, 2013). Disse bevegelsene vokste frem på midten av det 20. århundre som 
en reaksjon på medikaliseringen og teknologiseringen av døden, men også som talerør for en generell politisk og sosial «bølge» av ulike frigjøringsstrategier som krevde autonomi og en individuell tilnærming, også for døende pasienter. Beauvoirs bok kom samtidig med disse strømningene, og kan leses som en kritikk av samtidens forestillinger og praksiser rundt døden og den døende. Det er en kritikk hun selv rammes av, men som hun også retter mot andre: mot den kalde teknologiske tilnærmingen og hospitalets ensomme død.

\section{En lett og rolig død - allmenngyldig?}

I innledningen til dette kapitlet sier vi at Beauvoirs bok har allmenn interesse og gyldighet, også i dag. Samtidig har vi gjort et poeng av at forestillinger, holdninger og måten man håndterer den døende og døden på, er kulturelt og historisk situert. Så - hva er allment, og hva vekker gjenkjennelse i dag? Som vi nevnte, er dette en bok vi lar oss berøre av. Måten Beauvoir fletter morens biografi inn i fortellingen på, gir den dybde og gjør at vi forstår mer av relasjonen mellom de to. Beauvoir skriver at hun som oftest tenkte på moren med likegyldighet før hun ble syk, og at hun blir overrasket over sine egne sterke følelsesmessige reaksjoner (s. 91). Kanskje var det særlig morens ensomhet som rystet henne, en ensomhet som Simone de Beauvoir mente hun bidro til fordi hun løy for moren sin. Flere steder i boka skriver Beauvoir om hvordan moren og døtrene mentalt befinner seg på forskjellig «sted», fordi moren holdes for narr. Selv om det er grunn til å anta at open awareness (Glaser \& Strauss, 1965) omkring alvorlig sykdom og død er normen i dag, er kanskje den enkeltes ensomhet i møte med døden noe vi stadig rystes av?

Det er ikke lett å se og vurdere sin egen samtids praksiser og forestillinger utenfra. Det er heller ikke uten videre enkelt å vite hvordan de rådende normene og idealene for hva som i dag omtales som en god og verdig død, omsettes i praksis. Disse normene og idealene finner vi uttrykt i helsepolitiske dokumenter og i faglitteraturen. Her fremheves blant annet betydningen av respekt og åpenhet, at informasjon om at pasienten er døende, skal formidles til pasienten, og betydningen av at pasienten medvirker til beslutninger, for eksempel om å avslutte behandlingen (Helsedirektoratet, 2015). Dette ser ut til å være noe helt annet enn det Beauvoir forteller 
om. Hvordan åpenheten ivaretas i praksis, er imidlertid et annet spørsmål. Her er det trolig store variasjoner. Vi vet dessuten at helsepersonell fortsatt ofte kvier seg for å snakke med pasienten om livets sluttfase og døden. Et ytterligere tema i Beauvoirs bok er hvordan legene lar moren gjennomgå smertefulle undersøkelser og behandlinger selv om hun er døende. At dette stadig er en aktuell problemstilling, viser for eksempel utgivelsen av temaheftet Når er det nok? (Tholens, 2017). Her diskuterer norske leger og sykepleiere hvorfor det er så vanskelig å avslutte behandling og la alvorlig syke eller svært gamle mennesker dø. Relevant for dette er at Hviid Jacobsen (2009) har foreslått en femte fase av dødens historie, som han benevner den spektakulære og paradoksale døden (s. 26). Han argumenterer for at det i dag er større åpenhet og en form for demokratisering av døden - i den forstand at flere faggrupper ytrer synspunkter om den, samtidig som den generelle individualiseringen i samfunnet også viser seg i oppmerksomhet omkring ens egen død. Poenget hans er at vi i dag tror at vi kan velge eller påvirke hvordan vi skal dø, men at det paradoksalt nok ikke er så enkelt når det kommer til stykket, slik det viser seg i spørsmål om kommunikasjon, åpenhet og behandlingsbeslutninger. Også Wencke Mühleisens personlige og tankevekkende bok om sin egen mors siste fase og død, Jeg skulle løftet deg varsomt over (2009), illustrerer at flere av problemstillingene fra En lett å rolig $d ø d$ fremdeles er relevante. Følelsene av avstand og nærhet, utilstrekkelighet og omsorg, helsevesenets tilkortkommenhet og mange av de andre dimensjonene ved døden behandles og reflekteres over på måter som har mange likhetstrekk med Beauvoirs erfaringsnære og filosofiske tilnærming.

Interessant nok står En lett og rolig død på listen over forslag til videre lesning i det omtalte temaheftet. Det er flere enn oss som finner at denne lille boka synliggjør evig aktuelle temaer som åpenhet om og fortielse av alvorlig sykdom og død, helsepersonellets makt og ikke minst hvordan dødens sosiale, kulturelle og eksistensielle dimensjoner flettes sammen. Døden er et gjennomgangstema i Beauvoirs forfatterskap, og å skrive om døden var kanskje et forsøk på å komme til en forsoning med den. Men ifølge oversetter Bente Christensen skjedde aldri det for den franske forfatteren og filosofen. Morens dødsleie var en anledning til «å snakke om det», men Beauvoir grep ikke sjansen. Med En lett og rolig død har hun gitt denne sjansen videre til oss andre. 


\section{Referanser}

Ariès, Philippe (1976). Western Attitudes Toward Death: From the Middle Ages to the Present. London: Marion Boyars.

Ariès, Philippe (1981). The Hour of Our Death. New York: Knopf.

Ariès, Philippe (1985). Images of Man and Death. Cambridge, Mass: Harvard University Press.

Beauvoir, Simone de (1946). Tous les hommes sont mortels (Alle mennesker er dødlige). Paris: Gallimard.

Beauvoir, Simone de (1964/200o). En lett og rolig død (B. Christensen, Overs.). Oslo: Solum.

Beauvoir, Simone de (1960/2004). Moden alder (B. Christensen, Overs.). Oslo: Pax.

Beauvoir, Simone de (1970/2016). Alderdommen (B. Christensen, Overs.). Oslo: Vidarforlaget.

Glaser, Barney, \& Strauss, Anselm Leonard (1965). Awareness of Dying. New York: Aldine.

Graven, Vibeke, Lund, Louise, \& Hviid Jacobsen, Michael (2013). A Revival of Death? - Death, Dying and Bereavement in Contemporary Society. I M. Hviid Jacobsen (Red.), Deconstructing Death (s. 27-54). Odense: University Press of Southern Denmark.

Helsedirektoratet (2015). Nasjonalt handlingsprogram for palliasjon i kreftomsorgen. Hentet fra https://helsedirektoratet.no/Lists/Publikasjoner/Attachments/918/ Nasjonalt\%2ohandlingsprogram\%2ofor\%2opalliasjon\%2oi\%2okreftomsorgenIS-2285.pdf

Jacobsen, M. Hviid (2009). Den femte fase - med Philippe Ariès ind i det 21. århundrede. I Anders Gustavsson (Red.), Döden speglad i aktuell kulturforskning (s. 15-40). Uppsala: Sweden Science Press.

Malchau, Susanne (1993). Sygepleje af døende: $i$ et kvindehistorisk perspektiv 1926-1965. Århus: Skrift-serie / Danmarks Sygeplejerskehøjskole.

Moi, Toril (1995). Simone de Beauvoir: en intellektuell kvinne blir til. Oslo: Gyldendal. Mühleisen, Wencke (2009). Jeg skulle ha løftet deg varsomt over. Oslo: Gyldendal.

Rustad, Linda, \& Bondevik, Hilde (Red.) (1999). Kjønnsperspektiver i filosofihistorien. Oslo: Pax.

Saunders, Cicely, \& Clark, David (2006). Cicely Saunders Selected Writings 19582004. Oxford: Oxford University Press.

Tholens, Barth (Red.) (2017). Når er det nok? Hentet fra https://sykepleien.no/articlethemes/nar-er-det-nok 


\title{
KAPITTEL 9
}

\section{Metaforer om sykdom og død: en litteraturoversikt}

\author{
Aud Johannessen og Norunn Askeland \\ Universitetet i Sørøst-Norge
}

\begin{abstract}
Summary: This chapter is a literature review of metaphor research about illness and death within medical and health care from 2010 and onwards. The starting point of 2010 is based on David Southall's (2012) review of research about dying patients' use of metaphors, but our study also includes next of kin, health care personell and medical doctors. The review investigates the use of metaphor theories and definitions of metaphors in the studies, metaphors about illness and death used by the groups mentioned, and the conclusions in the papers regarding the usefulness and role of metaphors. The studies in our review find many of the same metaphors as Southall's (2012) studies do, like military metaphors, journey metaphors, family metaphors, nature metaphors and metaphors of sleep and rest. In addition, our study finds that researchers today are more critical to this, especially military metaphors about cancer. We also find defence of metaphors of hope even in hopeless situations, and of metaphors framing death as a spiritual journey, where anyone can travel in one's own time. As to the usefulness and role of metaphors, patients seem to appreciate caregivers' and doctors' use of metaphors from the domains of agriculture, the military and sports, especially within cancer treatment. In spite of the researchers' critical view of military and sport metaphors, patients find that such metaphors can enhance communication about their illness, especially if they are used for encouragement.
\end{abstract}

Keywords: death, hope, illness, literature review, metaphors

\section{Introduksjon}

En frekk innbruddstyv

Even as I sit here, he stands behind me clamping two colossal hand om my shoulders and bends down and whispers to my neck:

Sitering av denne artikkelen: Johannessen, A., \& Askeland, N. (2018). Metforer om sykdom om død: en litteraturoversikt. I A. Johannessen, N. Askeland, I. B. Jørgensen \& J. Ulvestad (Red.), Døden i livet (Kap. 9, s. 153-169). Oslo: Cappelen Damm Akademisk. https://doi.org/10.23865/noasp.40.ch9

Lisens: CC BY-NC 4.0 
From now on,

you write about me. ${ }^{1}$

(Bonanno, 2015)

Utdraget ovenfor er hentet fra et dikt om en person som bryter seg inn $i$ et hjem, kontrollerer telefonen, setter seg ved middagsbordet og spiser i taushet før han legger seg mellom ektefellene i sengen. Deretter legger han sine to kolossale hender på skuldrene til jeg-personen og hvisker i øret hennes: «Fra nå av er det meg du skal skrive om.» Det er døden som snakker, her framstilt metaforisk som en insisterende og frekk innbruddstyv. Å framstille døden som en person er vanlig i vår kultur. Mannen med ljåen er vel et av de mest kjente bildene på døden. Videre er det vanlig å bruke eufemismer, omskrivinger eller metaforer for det å dø. I dødsannonser leser vi ofte: «Hun har forlatt oss», og «Han sovnet stille inn» (Sexton, 1997, s. 340). Hendelser som gjelder sykdom og død, kan være vanskelige å uttrykke, men på dette området kommer metaforene oss til hjelp - som en linse som kan gi spesiell innsikt i måten vi forstår disse fenomenene på.

I dette kapittelet ønsker vi å gi en litteraturoversikt over forskning om bruk av metaforer i samtaler om sykdom og død blant pasienter, pårørende og helsepersonell. Allerede i 1979 uttrykte litteraturforskeren Wayne C. Booth (1979, s. 47) at interessen for metaforforskning var i sterk vekst. Han mente at vi i 2039 kom til å ha «more students of metaphor than people». En annen metaforforsker, Ray Gibbs Jr. (1999, s. 29), gjorde Booths ord til sine da han forsøkte å oppsummere metaforforskning før år 200o: «As we approach the millennium, I am beginning to believe that Booth's prophecy might turn out to be literally true.» Dette uttalte han tjue år etter at Booth hadde kommet med sin spådom. I mellomtiden hadde George Lakoff og Mark Johnson (1980) gitt ut sin bok Metaphors we live by, som viste hvordan metaforer er en integrert del av måten vi tenker på, og som gjorde at metaforforskningen skjøt enda mer fart og økte i volum, også innen forskning om metaforer knyttet til sykdom og død.

1 Gjengitt i henhold til sitatretten. Utdraget er ikke omfattet av bokas CC BY-NC 4.o-lisens, og kan ikke gjenbrukes uten tillatelse fra rettighetshaveren. 
Å gi en oversikt over denne omfattende forskningen er vanskelig, og som en starthjelp har vi tatt utgangspunkt i David Southalls (2012) litteraturstudie om døende pasienters bruk av metaforiske uttrykk i samtaler med helsepersonell. Southall (2012) fant at kognitiv metaforteori var dominerende i studiene, og at metaforene som ble brukt, kunne karakteriseres som militærmetaforer, reisemetaforer, familiemetaforer, naturmetaforer og søvn-/hvilemetaforer. Videre fant han at metaforene spilte en viktig rolle i å fremme kommunikasjon og forståelse i vanskelige samtaler, og at de var til nytte i omsorgen for døende.

I vår studie har vi sett på forskningslitteratur etter 2010, med de samme forskningsspørsmålene som Southall (2012), men utvidet dem til å gjelde både pasienter, pårørende og helsepersonell. Målet med vårt kapittel er å forsøke å gi svar på følgende tre spørsmål:

1) Hvilke metaforteorier og metafordefinisjoner er brukt i studiene?

2) Hva slags metaforer benyttes om sykdom og død av de ulike gruppene?

3) Hva framheves som metaforers rolle og nytte i omsorg for døende?

\section{Søkestrategier}

Det ble gjort et systematisk litteratursøk etter artikler som var publisert fra januar 2010 til januar 2017. For å få svar på forskningsspørsmålene arbeidet vi med å finne relevante søkeord - for deretter å kombinere disse slik at vi satt igjen med et håndterbart antall artikler (Forsberg \& Wengström, 2016). Det ble søkt i aktuelle databaser som CINAHL, PsychINFO, MEDLINE, Embase og Norart med bruk av følgende søkeord: death, death metaphor, dying people, figure of speech, hospice, metaphoric, narrative, palliative care, parable, terminal care og trope. Videre, for å finne relevant litteratur i nevnte databaser, valgte vi å inkludere studier skrevet på både engelsk og skandinavisk, med tilgjengelige sammendrag.

Ved å benytte denne metoden fikk vi fram 60 artikler i CINAHL, 72 artikler i PsychINFO, 65 artikler i MEDLINE, 16 artikler i Embase og 78 artikler i Norart. Vi leste alle sammendragene for deretter å lese hele artikkelen der det var aktuelt. I denne prosessen fant vi at 16 artikler 
kunne bidra til å besvare våre forskningsspørsmål. I tillegg benyttet vi oss av Scoping review som metode (Arksey \& O’Malley, 2005), hvor snøballmetoden og uformell muntlig forespørsel til aktuelle kontakter og nettverk ble benyttet. Én artikkel ble hentet fra nettverket (Johannessen et al., 2014), og denne ble inkludert i studien. Totalt ble 17 artikler tatt med. Vi har også lagt vekt på at disse er utformet etter kriterier som er godkjent av ulike etiske komiteer.

\section{Resultat og diskusjon Innledning om funn}

I det følgende vil funn bli presentert ut fra rekkefølgen til forskningsspørsmålene. I denne redegjørelsen vil noen av metaforene bli gjengitt på engelsk, fordi de ikke kan oversettes direkte til norsk.

\section{Teoretisk fundament og metafordefinisjoner}

Det første forskningsspørsmålet dreier seg om teoretisk fundament og metafordefinisjoner, og handler om hvilke teorier og metoder for definering og registrering av metaforer som er benyttet i studiene.

Innen metaforforskning skiller en gjerne mellom tre ulike tilnærminger: klassisk metaforteori (KMT), kognitiv metaforteori (CMT) og diskursorientert metaforteori (DMT). Grovt sett er forskjellen på tilnærmingene at KMT i tradisjonen fra Aristoteles ikke forbinder metaforbruk primært med tenkning, men ser på metaforer som et rent språklig fenomen. Derimot er CMT fast fundert på at språkbruk og tenkning henger nøye sammen, og at metaforene vi bruker, er fundert $i$ at kroppslige erfaringer manifesterer seg i språklige skjema i bevisstheten. Vi erfarer kroppen som en beholder, og dette gjør at vi ofte bruker beholdermetaforer om følelser, som når vi sier at vi er fulle av håp eller av mismot (Lakoff, 1999). Tilnærmingen DMT er representert av forskere som Lynne Cameron og Elena Semino (1999; 2008). Her dreier det seg om å undersøke metaforer i skrevne tekster og samtaler, og en tar ikke stilling til om de finnes i bevisstheten eller ikke. Metoden egner seg til 
å undersøke store tekstmengder. Flere av artiklene i vårt materiale gjør nettopp dette, men bare én av dem gjør det på grunnlag av DMT. Det gjelder undersøkelsen av profesjonelle helsearbeideres metaforer om håp i omsorg for døende (Olsman et al., 2014). Det kan tyde på at DMT ikke har særlig fotfeste - verken som teoretisk inngang eller som metode blant metaforforskere på dette feltet innen helsefagene.

Et stort flertall av artiklene går ikke nevneverdig inn på verken teori eller metode for metaforidentifisering, men tar for gitt at de fleste lesere er fortrolige med hva en metafor er, og hvordan den kan defineres. Grunnen kan være at mange av forfatterne ikke er språk- eller tekstforskere, men forskere innen helsefagene. Unntak fra denne regelen er studien til Bruce Arnold og Linda Lloyd (2014), som er utført av et tverrfaglig team, inkludert en litteraturviter og en poesiekspert. Andre unntak er Aud Johannessen et al. (2014), som utforsker metaforbruk hos yngre personer med demens. Her gjøres det greie for både teoretisk plattform og metoder for metaforidentifisering. Metode for metaforidentifisering gjøres også rede for av Stina Öresland et al. (2011), som tar for seg verdier og normer i hjemmesykepleie. Videre finnes det en grundig redegjørelse for CMT hos Jannicke Rabben og Berit Johannessen (2015), der positive og negative sider ved metaforer om kreft utforskes.

Mange artikler gjør imidlertid mye ut av å dokumentere tidligere forskning, altså forskning utført før 2000, og de påpeker hvor viktige metaforer er i kommunikasjonen. Her omtales blant annet Susan Sontags (1978) kjente essay om metaforer, i kombinasjon med studier som bygger på Lakoff og Johnson (1980), som representerer CMT. Sontags (1978) metaforsyn kan kort forklares som at en bør omtale sykdom uten å bruke metaforer, mens Lakoff og Johnsons (1980) metaforsyn går ut på at en ikke kan omtale verken sykdom eller andre fenomener uten å bruke metaforer. Her er teoriene tilsynelatende motstridende, men en kan også kalle dem kompletterende. Sontags studie (1978) dokumenterte at metaforer er til stede i alle diskurser, også i diskurser om sykdom, og poenget er at en ikke må omtale pasienter som offer eller gjøre dem ansvarlige for sykdommene sine. Å være kritisk til metaforbruk er også et hovedpoeng hos Lakoff og Johnson (1980), så slik sett kan en si at deres syn på metaforer har noe felles med Sontags (1978). 
Videre finner vi at flere artikler kombinerer KMT - gjennom henvisning til filosofen Paul Ricoeur (2003) - med CMT slik den er framstilt hos Lakoff og Johnson (1980). Dette er to tradisjoner som tilsynelatende ikke så lett lar seg forene, da Lakoff og Johnson (1980) har lagt stor vekt på at deres metaforteori er et brudd med KMT, der metaforer tradisjonelt har blir sett på som språklig pynt og ikke nær forbundet med måten vi tenker på. Men dette er også en forenkling når en tar Ricoeurs (2003) bidrag til metaforteori i betraktning. Han kombinerte fransk, tysk og angloamerikansk metafortilnærming. De artiklene som henviser til Ricoeur (2003), tar for seg temaer av eksistensiell karakter, som håp og spiritualitet og verdsettelse av åndelig liv (Olsman et al., 2014) eller språkbruk i terapeutiske dialoger i omsorgen for personer med demens (Johannessen et al., 2014). På dette feltet kan Ricoeur egne seg som grunnlag for analyse, da han som nevnt kombinerer mange tradisjoner og dessuten beskjeftiger seg med hermeneutikk og fenomenologi, noe man ikke i samme grad ser hos Lakoff og Johnson (1980). I tillegg er han opptatt av hvordan en med hjelp av metaforer kan skape en ny forståelse av virkeligheten, noe vi også finner i tradisjonen etter Lakoff og Johnson (1980).

Sammenfatningsvis kan en si at ulike metaforteorier og metoder for identifisering lever godt ved siden av hverandre innen helsefagene. Videre er det ingen tvil om at CMT er den dominerende retningen. Innenfor denne tradisjonen defineres bruken av metaforer som å overføre noe fra et kildedomene (f.eks. reise) til et annet kildedomene (f.eks. livet). Denne retningen har som nevnt fått kritikk for manglende presisjon når det gjelder å definere metaforer i sammenhengende tekst. At så mange studier i materialet støtter seg på CMT, kan forklare hvorfor det legges lite vekt på metafordefinisjoner og framgangsmåte for identifisering i flere av de undersøkte artiklene innen helsefaget.

\section{Ulike metaforer brukt innen helsefag}

I det følgende avsnittet kategoriseres metaforene, fulgt av aktuelle eksempel, der metaforene er kursiverte. For å få fram nyanser og rikdom i metaforbruken velger vi å kategorisere de ulike gruppenes praksis, før vi oppsummerer hvilke metaforer som brukes. 
Pasienter: Noen av pasientene som er undersøkt, er ikke i en døende fase, men under behandling eller pleie for langvarige sykdommer. En slik gruppe er medisinerte eldre med kroniske sykdommer (Beuthin et al., 2012). I denne studien identifiserte forskerne flere metaforiske temaer, noen positive og noen negative. Et negativt tema var å vore i fengsel, bli bombardert med medisiner og fôret med rottegift. Et annet negativt tema var knyttet til aldring og død, der metaforene går ut på at det går nedoverbakke, og at en må gjennom en kvern for å unngå å bli en byrde for samfunnet eller bli liggende der som en grønnsak. Kroppen omtales også med mekanistiske metaforer som pumpe, rør og press, der rørsystemet bryter sammen og kroppen slår seg av.

En annen studie (Johannessen et al., 2014) ser på metaforbruk hos personer med demens og finner tre metaforiske tema: å være utenfor, å legge igjen spor og å være helt alene i verden. Det første temaet kommer fram gjennom metaforer som å gli ut, å falle ut og å føle seg utenfor. Å få en demensdiagnose kan for noen føles som et stigma og som å få et stempel $i$ panna. For å bekjempe et stigma kan pasientene kjempe for å få tilbake et sosialt liv, og kan være nøye med å legge igjen spor der de har vært, slik at de husker hva de har gjort. De blir også opptatt av å være aktive og bruke hjernen for å hindre at de faller ut. Følelsen av å være helt alene i verden er sterkt til stede, og den uttrykkes også metaforisk gjennom at pasientene vet at de er alene og sammen med andre på samme tid.

Flere studier av døendes metaforer dreier seg om åndelig styrke og åndelige opplevelser (Arnold \& Lloyd, 2014; Mundle, 2011). Førstnevnte har utforsket to «spiritual strength stories» gjennom case-studier og funnet at slike historier er korte, at de bruker symboler og metaforer, at de fokuserer på det åndelige og religiøse, og at de er repeterende. I den ene casen presenterer pasienten, James Oak, seg som the tree of life, forst som en spøk, men senere kommer det fram at det er en mening i denne metaforen. Eiketrær er store og sterke, og de gir næring, ly og beskyttelse til mindre dyr. Dette var en funksjon som var viktig for denne pasienten. Faren hans hadde dødd av hjerteinfarkt, og dette ble beskrevet med en tremetafor som at han ble cut down with a crash. Pasienten ønsket å være en person som vokser åndelig, med samme kraft som et eiketre kan vokse. 
I den andre casen er det en pasient med demens som presenterer seg slik: «I am Doris Sara Loxley, and I am lost in a fog, so we sent Willy, A St. Bernard's Dog, who found me and brought me safely home, so we gave him a big juicy bone.» I dette lille diktet er det både metaforer, symboler og mening, noe rytmen og rimet støtter opp under. Legen som behandlet denne pasienten, la seg diktet på minne og brukte det i samtaler med pasienten for å bekrefte hennes opplevelse av egen situasjon.

Studien til Arnold og Lloyd (2014), som er den eneste som har inkludert litteraturvitere i forskergruppen, dreier seg om hvordan døende pasienter snakker om åndelige opplevelser. Deres erfaringer uttrykkes på flere måter. Mange vegrer seg for å snakke om det, til tross for at de mener slike erfaringer er viktige. Når de snakker om det, er det for noen som en lek, gjennom å beskrive materielle og jordiske opplevelser, enkle ting som andre tar for gitt, som god kaffe eller gode venner. Pasientene ser ting på nye måter, og uttrykker det med metaforer som at alt blir forstørret og forklaret, gjennom en slags oppvåkning og brå overgang fra én tilstand til en annen og bedre tilstand. Det mest framtredende trekket ved de åndelige opplevelsene er fred og tilfredshet. Pasientene kan føle at de flyter på luft, eller at de er i en slags konvolutt av kjorlighet og tilfredshet. De har sluttet fred med fortiden og er ikke redde for å d $\varnothing$ - fordi de vet hvem som er skaperen og hvor de skal. Her ser vi at synsmetaforen er underliggende for å beskrive forstålse (å se ting på nye måter uttrykker at å se er å forstå), og at reisemetaforen er sentral enten gjennom mentale reiser og overganger eller gjennom at selve døden oppfattes som en reise.

Reisemetaforen er altså til stede i flere av de omtalte studiene om pasienter, der det er snakk om sykdom, liv og død. Vi ser også at søvn-/hvilemetaforen er til stede, og at naturmetaforer er representert, som $i$ «tree of life». Disse tre metafortypene var også representert i Southalls (2012) studie.

Pårørende: To av studiene berører pårørende, men har ulike perspektiv. Den første omhandler kjærlighet og død, nærmere bestemt hvordan et barns død kan påvirke relasjonen mellom foreldrene (Umphrey \& Cacciatore, 2014). Her beskrives relasjonen mellom foreldrene som det å være i bevegelse, som en levende organisme og metaforisk som en reise. Tapet 
av barnet kunne føles som en amputasjon og som å vore $i$ en sterk malstrøm eller på en endeløs vei. Sorgen beskrives primært som en type reise, og kommunikasjonen mellom partene beskrives metaforisk som en dør som er åpen eller stengt. Sorgen kan føre til at partene kommer noermere hverandre, at de kan støtte seg til hverandre, og den kan være noe som sementerer og knytter dem mer sammen. Men den kan også føre til at partene glir fra hverandre og at de må skille lag. For noen ble sorgen uttrykt og opplevd som elefanten $i$ rommet, noe man listet seg på tå rundt, noe som stengte for kommunikasjon. Uansett fortalte de pårørende at reisemetaforen var til nytte i sorgprosessen. Når sorg forstås som å navigere i vanskelig terreng, kan den som sørger, bedre forstå hvorfor sorg noen ganger er vanskelig og andre ganger lettere å leve med.

En annen studie utforsker hvordan pårørende til kreftpasienter som søker alternativ behandling, oppfatter metaforer om kreft, og her drøftes positive og negative sider ved metaforene (Rabben \& Johannessen, 2015). De pårørende knytter sine erfaringer til håp om overlevelse og økt livskvalitet og beskriver en kamp mot kreft, der bruken av militærmetaforer er tydelig. Bruken av slike metaforer kan ifølge forskerne påvirke både pasienter og pårørende negativt, ved at en rettferdiggjør bruk av alle våpen - inkludert medisinsk fåfengt behandling - i stedet for å dra nytte av tiltak som kan øke livskvaliteten den tiden en har igjen.

For gruppen pårørende er både reisemetaforen og militærmetaforen i bruk for å beskrive sorg og sykdom, særlig kreft, også når alt håp ser ut til å være ute. Dette siste er også påpekt av Southall (2012).

Studenter og pleiere: Bare én artikkel tar for seg metaforbruk blant sykepleierstudenter (Jo \& An, 2012). Hele 133 koreanske studenter er blitt intervjuet om død gjennom åpne spørreskjema og egne kunstneriske kollasjer. Gjennom studier av svar og kollasjer dukket det opp fire metaforiske temaer, og disse er knyttet til fysisk hvile (på en reise), psykologisk frykt, separasjon og nytt åndelig liv. Forfatterne hevder at død i Korea ofte blir uttrykt indirekte med eufemismer, noe som også er vanlig i vestlige land. Til tross for disse likhetene hevder Kae Jo og Gyeong An (2012) at angsten for død er lavere i asiatiske samfunn enn i vestlige, og de hevder videre at asiater ser på døden som en overgang til en annen eksistens og ikke 
som noe endelig. Denne oppfatningen kommer også til syne i studentenes bruk av metaforer: «Døden er et komma, ikke et punktum. Livet er en pause på hele reisen, og jeg tror at livet og døden er tett forbundet med hverandre.» Å dø blir også sett på som å betale tilbake et lån, livet, og som en evig søvn i vakre pastellfarger (Jo \& An, 2012).

Studien deres viser også at metaforene knyttet til frykt uttrykkes som noe uventet og truende, akkurat som aksjekurser som kan gå opp og ned, eller som en person som følger deg hele livet. Døden kan være uklar som en tåkete dag, eller den kan være som et svartkledd monster. Videre kan den oppfattes som å passere en lang og mørk tunnel og som å gå på en vei der det ikke er mulig å komme tilbake.

Andre og mer positive metaforer i den samme studien dreier seg om å se døden som begynnelsen på et nytt liv, som å gå inn en port til en ny verden, eller som et nytt startpunkt, akkurat som livet var det. Døden står også for lys og håp om å bli husket av sine kjære og kanskje møte dem igjen. Og sist, men ikke minst, ses døden på som inngangen til en ukjent verden over regnbuen der mennesker lengter etter å komme inn i himmelen.

Jo og An (2012) hevder at noen av metaforene er typisk koreanske, da det er vanlig i Korea å si at han har returnert når noen er død. Når det uttrykkes usikkerhet og sorg rundt døden, eller når den oppfattes som et monster, mener de det reflekterer koreansk sjamanisme, der sjeler i dyp sorg ikke dør, men vandrer rundt i underverdenen i et strevfullt raseri. Slike metaforer representerer et ønske om ikke å dø hos de studentene som ble intervjuet.

I omtalen av pleiere (sykepleiere og andre pleiere) alene er to studier aktuelle. Den ene ser på hjemmesykepleie, og omtaler pleie av døende som an endless journey (Öresland et al., 2011), en endeløs reise mot et ukjent mål. Pleierne omtaler seg selv som en reisefelle på pasientens helsereise, men er samtidig både konduktør og kontrollør, gjennom at de bestemmer veien som skal gås, og sjekker at pasienten gjør som avtalt. De snakker om å voere i forkant av pasienten og om å lykkes i å fa pasienten med på noe. Pasienten kan ha mange sykdommer i bagasjen, og er noen ganger $p a ̊$ riktig vei, mens det andre ganger går nedover med ham eller henne. Alle disse reisemetaforene ses som uttrykk for at pleierne er reiseledere som «eier» pasienten og har makt over vedkommendes helsereise. 
Også på sykehjem viser reisemetaforen seg egnet for å beskrive hvordan pleiere erfarer final journeys (Dempster, 2012). De beskriver de eldres reiser både som fysiske og åndelige. De fysiske reisene dreier seg om reisen fra de eldre kommer inn på sykehjemmet til de hentes av begravelsesbyrået. Reisen deles inn i stadier fra rutine til «pre-death», død, «post-death» og siste reise. Et felles prosjekt for pleiere og pårørende er å create a good sendoff [skape en god reise], å få den døende vel av gårde på sin åndelige reise, som er en reise til et bedre sted, slik pleierne uttrykker det. Da skal pasienten reise tilbake til den alderen han eller hun var lykkelig og uten smerter. Pleierne forteller også at de åpner vinduet for at sjela skal kunne fly ut etter at pasienten har utåndet. De forteller videre at de ikke ser på pasientene som døde, men som levende som sover. Etter pasientens død gjør pleierne også sitt for at de skal leve videre gjennom en minnereise og en mytisk reise ved at de igjen og igjen forteller hverandre om spesielle, ofte morsomme, hendelser med pasientene. Dermed skaper reisemetaforen mening og kontinuitet i det pleierne gjør. Å minnes pasienter skaper symbolsk udødelighet gjennom at pleierne lager forbindelser mellom reiser, myter og religion og skaper sin egen mening, teologi og tro som blir en del av det å minnes de levende.

Militærmetaforer synes ikke å være til stede i akkurat disse to studiene, til tross for at den er sterkt til stede i diskursen om kreft, slik det er påvist i en studie av Kristine Harrington (Harrington, 2012). Harrington peker på at USA har erklært krig mot kreft siden 1971, og selv om mange har protestert mot metaforen, er den fremdeles sterkt til stede i helsekommunikasjon om kreft. Kreften invaderer og angriper kroppen, og behandlingen går ut på å finne våpen til å bekjempe kreften med, en behandling som har som bivirkning at også friske celler blir drept av våpnene. Ideen med å starte en destruktiv og voldelig krig for å redde liv strider mot manges ønsker. I tillegg til at militærmetaforen er et filosofisk problem, kan den virke negativt inn på pasientene, fordi de må undertrykke egne følelser for å vise «fighting spirit», og det kan føre til at de ser på kreften mer som en fiende enn som en utfordring, hevder Harrington (2012). I en krig er det vinnere og tapere, og den som ikke blir frisk av kreft, kan komme til å se på seg selv som en taper eller en fiasko. Reisemetaforen, derimot, kan lettere gi rom for at pasientens egne behov blir sett og møtt, i og med at 
hver pasient kan reise i sitt eget tempo på sin egen vei. Harrington (2012) peker også på andre metaforer om kreft, som gåte og mysterium. Disse kan føre til at en legger mer vekt på å løse kreftgåten enn på omsorg for pasienten. I lys av kritikken av militærmetaforer og andre metaforer er det interessant å merke seg at metaforer som gåte og mysterium ikke er registrert blant pleiere i denne litteraturgjennomgangen.

Leger: Legenes metaforer er noe annerledes enn pleiernes, men har også noe felles med dem. Dette kommer særlig fram i en artikkel om hvordan allmennpraktiserende leger opplever døden til pasientene sine (Zambrano $\&$ Barton, 2011). De opplever at de er på reise med pasienten, en reise som har flere faser. I den første fasen, der pasienten får en diagnose, opplever legen seg som en budbringer med dårlige nyheter. I den andre fasen skal legen kommunisere diagnosen til pasienten og familien, og er nødt til å snakke klart og ikke pakke inn budskapet. Legene opplever dette som et sterkt, dystert og mørkt møte. I tredje fase fortsetter legen å bistå pasienten, men pasienten får nå gjerne behandling av spesialister. Den allmennpraktiserende legen kan da opptre mer som en venn enn som en lege, eller i alle fall som en ledsager. I den fjerde fasen, som begynner når legen skriver ut dødsattesten, vil legen noen ganger være lettet på vegne av familien, og begynner umiddelbart å tenke på hvordan familien kan tas vare på. Uavhengig av faser på denne reisen viste det seg at legene hadde sine mekanismer for å takle vanskelige situasjoner. Det kunne være å snakke med kollegaer, finne noe positivt i situasjonen, akseptere døden eller drikke alkohol, om det hadde vært en dårlig dag eller en dag med følelsesmessige påkjenninger på vegne av pasienten.

En studie av Erik Olsman med kollegaer (2014) handler om å kommunisere håp til pasienter, og her er leger, pleiere, prester og andre profesjonelle inkludert. I denne studien ble det funnet fire metaforer knyttet til håp, og som alle har med kroppen å gjøre: håp som et grep (å få tak på noe, trygghet), håp som kilde (som gir styrke), håp som melodi (som medfører harmoni) og håp som visjon (som medfører et positivt perspektiv eller en lys framtid). Det ble hevdet at en ikke skulle ta håpet fra pasienten, og at det ikke var uvanlig å gi time til en pasient som var døende. De som ble intervjuet, var opptatt av å utvikle en håpets etikk og bruke den i samtale 
med pasienter for å gi dem noe å se fram til og leve mot. De fire metaforene om håp ovenfor har en åndelig dimensjon, og Olsman et al. (2014) hevder at det åndelige er lite verdsatt på sykehus.

I omtalen av døende pasienter brukes gjerne metaforen terminal, som blant annet kan bety sluttpunkt eller endestasjon på en reise. Justin V. Cohen (2015) reflekterer over legers bruk av denne metaforen og mener den framstiller sykdom som en togreise, der pasienten strever med å holde seg på skinnene på en reise der formålet med livet er å leve det. Pasienten var forberedt på turen, men ikke på målet for reisen, som er døden eller endestasjonen (terminalen). Terminal kan også gi mulighet for sporskifte og nye reiser mot ukjent framtid. Og for noen er terminal sykdom blitt endret til terminalt liv, der det beste helsepersonell kan gjøre, er å «help them cope and move on».

Oppsummeringsvis er de dominerende metafortypene i materialet $i$ høy grad de samme som dem vi finner omtalt hos Southall (2012). Reisemetaforer og militærmetaforer dominerer, sammen med naturmetaforer og metaforer om søvn og hvile. I tillegg er det i vårt materiale også mekanistiske metaforer, metaforer om sorg, håp og åndelige reiser og åndelig styrke hos pasienter, og metaforer der livet omtales som lån. Vi har også funnet sportsmetaforer og metaforer om døden som en port eller en dør inn til et annet liv. Materialet vårt omfatter dessuten en større grad av metaforkritikk enn det Southall (2012) har funnet i sitt materiale, særlig gjelder dette legenes refleksjoner over reisemetaforenes fortrinn over militærmetaforer og deres nytolkninger av tradisjonelle metaforer om død, som terminal. Det vil si at ikke alle metaforer blir sett på som nyttige, men at noen kan være direkte misvisende og til og med hindre kommunikasjon. Andre metaforer kan gjøre både livet og døden lettere å bære. Dette bringer oss over til det siste forskningsspørsmålet.

\section{Metaforens rolle og nytte i omsorg for syke og døende}

Så å si alle studiene legger vekt på at vi ikke klarer oss uten metaforer, og at de er et godt hjelpemiddel i arbeidet med å forstå hverandre i vanskelige situasjoner. Men den som kan svare best på spørsmålet om 
metaforens nytte i omsorg for syke og døende, må kanskje være pasienten selv. En studie av David Casarett og kollegaer (2010) har utforsket pasienters vurdering av metaforer og analogier hos helsepersonell. Det viser seg at de legene som fikk best vurdering av pasientene, var de som brukte mange metaforer, gjerne tydelige sådanne. Det kunne være jordbruksmetaforer som frø, ugress og ugressdreper, eller militærmetaforer knyttet til angrep og forsvar, gjerne i kreftbehandling. Til tross for at slike metaforer er mye kritisert av både leger og forskere, ser pasientene ut til å finne mening i dem. Det gjelder også mekaniske metaforer med uttrykk som av- og på-bryter samt høyt og lavt gir brukt om kroppen. Pasientene setter særlig pris på at legene bruker sportsmetaforer og forklarer at behandlingen de får, er som en maraton, ikke som en sprint. Det kan også være sammenligninger som at en kreftkul kan se ut som en ert, eller at resultatet av stråling kan se ut som solforbrenning, og at pasienten etter behandling kan føle seg som om han har blitt sparket av en hest. Ved nye former for behandling får pasienten vite at hun er en pioner, noe mange liker å høre. En del av disse metaforene er hentet fra kreftbehandling, og selv om noen av dem kan kritiseres, er det ingen tvil om at det å bruke metaforer og analogier er en tilleggskompetanse som kan fremme kommunikasjon. Casarett og kollegaer (2010) hevder også at metaforer kan brukes til å trøste og oppmuntre, men legger til: «figurative speech might produce substantial harm if it is used to minimize or obscure important information about a patient's illness trajectory or prognosis». Forfatterne synes likevel å være opptatt av å understreke nytten av at helsepersonellet lytter til pasientenes metaforer og bruker dem videre i sin egen kommunikasjon. Løpende kommunikasjon med pasienter er for de fleste overordnet medisinsk presisjon og fagspråk.

\section{Metodekritikk og begrensninger}

Bias i denne studien kan være at vi ikke har fătt fram de rette søkeordene, fordi det er kulturelle og faglige forskjeller i ulike land. Det kan også være forskjeller i språkforståelse, da flere av studiene vi omtaler, er utført i land der forskerne ikke nødvendigvis har engelsk som morsmål. 
Vi vil også presisere at denne studien ikke omhandler andre fagfelt enn medisin og helsefag. Innen tekstforskning finnes det flere og omfangsrike studier om metaforer knyttet til sykdom og død, men disse er av plassgrunner ikke med i denne litteraturgjennomgangen.

\section{Avsluttende kommentarer}

I denne litteraturstudien har vi funnet mer metaforkritikk og flere metaforer knyttet til håp enn det som ble vektlagt i Southalls (2012) studie. For å markere dette vil vi avslutte med en refleksjon av Larry Cripe (2016) fra vårt materiale. Han reflekterer over en kreftpasient som så gjerne ville at det skulle være håp i livets siste fase, men forteller at han som lege ikke kunne gi pasienten det håpet. Senere har han kommet til at han skulle ha gjort det, for - som han sier - kilden til håp er et stort mysterium. Mye tyder på at behandling med cellegift kan føre til håpløshet. Cripe (2016) har kommet til at pasienter kan dø med et stort håp inne i seg, uavhengig av behandling, og videre at håpet som iboende egenskap henger sammen med helbredelse. Han mener at de historiene vi forteller om håp, kan påvirke hvordan en døende person nærmer seg slutten av livet, med eller uten håp. Det som fikk han til å reflektere over dette, var synet av en død fugl i hagen, noe som medførte at Emily Dickinsons metaforiske dikt om håp ble tydelig for ham:

Hope is the thing with feathers

That perches in the soul

And sings the tunes without the words

And never stops at all

(Dickinson, sitert etter Cripe, 2016)

\section{Referanser}

Arksey, Hilary, \& O’Malley, Lisa (2005). Scoping studies: Towards a methodological framework. Int J Soc Res Methodol, 8(19), 19-32. https://doi. org/10.1080/1364557032000119616

Arnold, Bruce L., \& Lloyd, Linda S. (2014). Harnessing complex emergent metaphors for effective communication in palliative care: A multimodal perceptual analysis of 
Hospice patients' reports of transcendence experiences. American Journal of Hospice and Palliative Medicine, 31(3), 292-299. https://doi.org/10.1177/1049909113490821

Beuthin, Rosanne E., Holroyd, Ann, Stephenson, Peter H., \& Vegsund, Britt (2012). Metaphors and Medication: Understanding Medication Use by Seniors in Everyday Life. Canadian Journal of Nursing Research, 44(3), 150-168.

Bonanno, Kathleen S. (2015). Death Barged In. Academic Medicine, 9o(9), 1270. https://doi.org/10.1097/ACM.ooooooooooooo753

Booth, Wayne C. (1979). Metaphor as rhetoric. The problem of evaluation. I Sheldon Sachs (Red.), On Metaphor. Chicago: University of Chicago Press.

Cameron, Lynne (1999). Operationalising «metaphor» for applied linguistic research. I Lynne Cameron \& Graham Low (Red.), Researching and Applying Metaphor. New York: Cambridge University Press, 3-28.

Casarett, David, Pickard, Amy, Fishman, Jessica M., Alexander, Stewart. C, Arnold, Robert M., Pollak, Kathryn I., \& Tulsky, James A. (2010). Can metaphors and analogies improve communication with seriously ill patients? Journal of Palliative Medicine, 13(3), 255-260. https://doi.org/10.1089/jpm.2009.0221

Cripe, Larry D. (2016). Hope Is the Thing With Feathers. Jama, 315(3), 265-266. https://doi.org/10.1001/jama.2015.18557

Cohen, Justine V. (2015). Terminal life. JAMA Oncology, 1(6), 731. https://doi. org/10.1001/jamaoncol.2015.1533

Dempster, Paul G. (2012). Memorialisation and the metaphor of final journeys: Workers' experiences of dealing with death within care homes for the elderly. Mortality, 17(3), 221-239. https://doi.org/10.108o/13576275.2012.696808

Forsberg, Christina, \& Wengström, Yvonne (2016). Att göra systematiska litteraturstudier. Stockholm: Natur och Kultur.

Gibbs, Raymond W. Jr. (1999). Researching metaphor. I Lynne Cameron \& Graham Low (Red.), Researching and Applying Metaphor. New York: Cambridge University Press, 29-47.

Harrington, Kristine (2012). The Use of Metaphor in Discourse about Cancer: A Review of the Literature. Clinical Journal of Oncology Nursing, 16(4), 408-412. https://doi.org/10.1188/12.CJON.408-412

Jo, Kae H., \& An, Gyeong J. (2012). Death metaphors in Korean undergraduate nursing students. Holistic Nursing Practice, 26(2), 79-86. https://doi.org/10.1097/ HNP.obo13e31824621f3

Johannessen, Aud, Möller, Anders, Haugen, Per K., \& Biong, Stian (2014). A shifting sense of being: A secondary analysis and comparison of two qualitative studies on young-onset dementia. International Journal of Qualitative Studies on Health and Well-being. 9, 24756. https://doi.org/10.3402/qhw.v9.24756

Lakoff, Georg, \& Johnson, Mark (1980). Metaphors We Live By. Chicago: University of Chicago Press. 
Lakoff, George (1999). Philosophy in the Flesh: The Embodied Mind and Its Challenge to Western Thought. New York: Basic Books.

Mundle, Robert G. (2011). The spiritual strength story in end-of-life care: Two case studies. Palliative \& Supportive Care, 9(4), 419-424. https://doi.org/10.1017/ S1478951511000447

Olsman, Erik, Duggleby, Wendy, Nekolaichuk, Chery, Willems, Dick, Gagnon, Judith, Kruizinga, Renske, \& Leget, Carlo C. (2014). Improving communication on hope in palliative care. A qualitative study of palliative care professionals' metaphors of hope: grip, source, tune, and vision. Journal of Pain and Symptom Management, 48(5), 831-838. https://doi.org/10.1016/j.jpainsymman.2014.02.008

Rabben, Jannicke, \& Johannessen, Berit (2015). Å være pårørende når alternativ behandling tas i bruk i «kampen mot kreft». Nordisk tidsskrift for helseforskning, 11(1), 104-121. https://doi.org/10.7557/14.3483

Ricoeur, Paul (2003). The Rule of Metaphors: The Creation of Meaning in Language. London: Routledge \& Kegan Paul.

Semino, Elena (2008). Metaphor in Discourse. Cambridge: Cambridge University Press.

Sexton, James (1997). The Semantics of Death and Dying: Metaphor and Mortality. A Review of General Semantics, 54(3), 333-345.

Sontag, Susan (1978). Illness as Metaphor. New York: Farrar, Strauss \& Giroux.

Southall, David (2012). The patient's use of metaphor within a palliative care setting: Theory, function and efficacy. A narrative literature review. Palliative medicine, 27(4), 304-313. https://doi.org/10.1177/0269216312451948

Umphrey, Laura R., \& Cacciatore, Joanne (2014). Love and death: Relational metaphors following the death of a child. Journal of Relationships Research, 5 . https://doi.org/10.1017/jrr.2014.4

Zambrano, Sofia C., \& Barton, Christopher A. (2011). On the journey with the dying: How general practitioners experience the death of their patients. Death Studies, 35(9), 824-851. https://doi.org/10.1080/07481187.2011.553315

Öresland, Stina, Määttä, Sylvia, Norberg, Astrid, \& Lützén, Kim (2011). Homebased nursing: An endless journey. Nursing Ethics, 18(3), 408-417. https://doi. org/10.1177/0969733011398098 



\title{
Hvilken farge har døden? En analyse av Erling Forfang og Annlaug Auestads bildebok: Noen sier døden er svart (2006)
}

\author{
Eva Maagerø \\ Universitetet i Sørøst-Norge
}

\begin{abstract}
Summary: In this article, the use of colours in the picture book Noen sier at døden er svart (Some say that death is black) by Erling Forfang and Annlaug Auestad (2006) is analysed. The book is about the young boy Alfred who reflects upon the colour of death after a friend has died. In his reflections, colours play a major role, and with the help of their meaning, he manages to get an understanding of death in a way he can live with. The colours are analysed in a social semiotic framework inspired mainly by Kress and van Leeuwen (2006), Machin (2007) and van Leeuwen (2011). They see colour as a semiotic system with a meaning potential to represent the world around us and in us, to interact with the viewers/readers and to create cohesion in texts. In the analysis, connotations to what colours represent, and the effect they may have on the viewers/readers, is emphasized. Meaning-making by colours is not understood as universal, but is related to a cultural context. Death is a complex topic, especially for young children. This article shows how the cultural meaning of colours is used to grasp and concretize the complex question of death and what follows after death.
\end{abstract}

Keywords: colour as meaning making, multimodality, picture book, social semiotics

\section{Introduksjon}

Døden er et vanskelig tema å ta opp med små barn. At mennesker og dyr dør og blir borte for alltid, er noe av det mest skremmende et lite barn kan tenke seg. Det kan til og med skje at mennesker det lille barnet er sterkt knyttet til, dør: en mor, en far eller et søsken. I bildebøker for små barn har døden tradisjonelt sett ikke vært et hyppig tema, og hvis noen har dødd i fortellingen, har det gjerne vært et dyr som familien er glad i. Dermed ble bildeboka Farvel, Rune av Marit Kaldhol og Wenche Øyen,

Sitering av denne artikkelen: Maagerø, E. (2018). Hvilken farge har døden? En analyse av Erling Forfang og Annlaug Auestads bildebok: Noen sier døden er svart (2006). I A. Johannessen, N. Askeland, I. B. Jørgensen \& J. Ulvestad (Red.), Døden i livet (Kap. 10, s. 171-188). Oslo: Cappelen Damm Akademisk. https:// doi.org/10.23865/noasp.40.ch1o

Lisens: CC BY-NC 4.0 
som kom ut i 1986, et viktig bidrag til å ta opp dette temaet. I boka opplever ei lita jente at bestevennen hennes, Rune, drukner og dør. Rune er et barn, ikke en gammel bestemor eller bestefar som har levd et langt liv. Akkurat dette gjør boka svært sterk, og for mange som var barn på 1980og 1990-tallet, ble den et av de viktigste litteraturminnene fra skolen. Barnebokforfatteren Maria Parr skriver: «Fyrste gongen vi las «Farvel, Rune» opna det seg noko eg ikkje hadde skjøna var der. (...) Det var før og etter «Farvel, Rune». Før og etter at det fanst noko som heitte å døy.»

Etter Kaldhol og Øyens bok har det kommet mange liknende bøker for barn. Nyere skandinaviske bildebøker er kjent for å ta opp problematiske temaer som ensomhet, mobbing, skilsmisse, vold, overgrep, sykdom og død (Ommundsen, 2016). Tilnærmingen til døden gjøres på forskjellige måter av de ulike forfatterne og illustratørene. Her skal bare tre bildebøker nevnes: I Iben Sandemoses Fiat, farmor og den hvite løven fra 2014 er det en farfar som dør. Fiat og farmor finner farfar død i en stol. De tror han sover, men når de klyper ham i nesa, og han ikke reagerer, skjønner de at han er død. De gråter og er lei seg, men så husker de på at farfar har sagt at de kan gjerne gråte når han dør, men de må huske å ri på løver også. Derfor steker farmor pannekaker, og de leker med en stor hvit løve. Sandemose kombinerer død og sorg med humor, noe som også andre bildebokforfattere gjør når dette temaet tas opp. I Annas himmel fra 2013 forteller Stian Hole gjennom illustrasjoner av blant annet vakre og fantasifulle naturlandskap samt fargerike fugler og dyr historien om Anna, som har mistet moren sin. Anna reiser til himmelen for å besøke moren, som har blitt gartner der, og Anna mener at Gud nok kan trenge litt hjelp med hagen siden han har så mye annet å gjøre. Det er tydelig at Annas måte å forstå morens død på også hjelper pappa over den verste sorgen. Gaute Heivoll og Øyvind Lauvdahl ga i 2008 ut bildeboka Himmelen bak huset, som også har blitt filmatisert. ${ }^{2}$ Som i Stian Holes bok dreier det seg om en mamma som er død. Allikevel kommer hun på besøk til Jon hver kveld før han sovner. Det er et nært forhold mellom Jon og pappaen som begge sørger på hver sin måte og hjelper hverandre i sorgen. Både

\footnotetext{
1 Barnebokkritikk.no

2 Steffan Strandberg: Himmelen bak huset (2011).
} 
illustrasjonene og verbalteksten gjør boka til en poetisk fortelling om det å miste en av sine aller nærmeste.

I dette kapittelet skal det dreie seg om bildeboka Noen sier at døden er svart av Erling Forfang og Annlaug Auestad. Den kom ut i 2006 på Wigestrand forlag. Hovedpersonen er Alfred, som filosoferer over døden og hvilke farger den har. Han trekker ofte inn venninna Marie i tankene sine. Broren til Marie, Bjørn, er død, og det er dette Alfred forsøker å komme til rette med i boka. Han tar utgangspunkt i farger for å reflektere over døden. Fargene og konnotasjoner knyttet til dem blir en ressurs for Alfred når han forsøker å fange inn og konkretisere tankene sine om et av de mest komplekse spørsmålene som mennesker har strevd med til alle tider: Hva skjer med oss når vi dør? Boka vil i dette kapittelet bli undersøkt med særlig vekt på farger som meningsskaping og som viktig ressurs for hovedpersonens refleksjoner. Dessuten tas samspillet mellom fargene og illustrasjonene og verbalteksten på oppslagene opp.

\section{Farge som meningsskaping}

Analysen vil bygge på et sosialsemiotisk rammeverk. I sosialsemiotikken er man opptatt av meningsskaping i sosiale situasjoner der mennesker møtes og kommuniserer med hverandre. Når mennesker kommuniserer, gjør de det gjennom ulike meningsskapende (eller semiotiske) ressurser som språk, bilder, bevegelse, blikk, gester, lyd, musikk, farger osv. Den britiske lingvisten Michael Halliday (1978) var den som først utviklet dette fagområdet. Han var mest opptatt av verbalspråk som meningsskapende system og har beskrevet språklig meningsskaping på en svært detaljert måte i en rekke utgivelser (se bl.a. Halliday \& Matthiessen, 2014). Halliday forklarer et meningsskapende system gjennom tilstedeværelsen av tre metafunksjoner - eller grunnleggende former for mening: den ideasjonelle metafunksjonen (språk kan representere virkeligheten i oss og rundt oss), den mellompersonlige metafunksjonen (språk har ressurser til å realisere interaksjon mellom kommunikasjonspartnerne) og den tekstuelle metafunksjonen (språk har også ressurser til å skape sammenhenger slik at deler kan inngå i større enheter). Alle tre er til stede samtidig i språklig kommunikasjon. Andre 
sosialsemiotikere, som Michael O'Toole (1994) og Kress og van Leeuwen (2006), har i sine arbeider vist hvordan Hallidays rammeverk kan utvikles videre innenfor visuell meningsskaping som bilder og tredimensjonale objekter. Kress og van Leeuwen omtaler de tre metafunksjonene som representasjon, interaksjon og komposisjon, og det er disse begrepene som benyttes videre i dette kapittelet.

Analysen av boka Noen sier døden er svart er ikke en bred sosialsemiotisk analyse. Bildeboka tematiserer døden gjennom farger, og det er farger som meningsskaping som skal undersøkes. Kress og van Leeuwen (2001; 2006), Machin (2007) og van Leeuwen (2011) har alle vært opptatt av farge som meningsskapende system. De hevder at farge på samme måte som språk og bilder kan representere virkeligheten, interagere med betrakteren og bidra med å skape sammenheng i komposisjonen til en tekst eller et kulturelt objekt, dvs. realisere alle tre metafunksjonene. Kress og van Leeuwen (2006, s. 229) sier: "We think that colour is used metafunctionally, and it is therefore a mode in its own right.» Painter mfl. (2013, s. 35) slutter seg til dette synet i sitt arbeid med bildebøker:

Colour is a visual resource that can serve all three metafunctions. ... In its ideational role, colour is used to represent the appearance of things in the world, with green for grass, yellow for gold sovereigns, white for snow, red for blood, and so on. In its textual role, colour may be used contrastively to highlight or foreground some elements within a composition to make it especially salient to the viewer, or repetitions of a colour may be used cohesively as a kind of visual rhyme to link different parts of a narrative. In its interpersonal role, however, the significance of colour lies in its emotional effect on the viewer.

Farger kan altså representere virkeligheten i oss og rundt gjennom konnotasjoner. Vi relaterer en farge i et bilde for eksempel til fargene vi ser i naturen, og til kulturelle objekter og fenomener. Blått kan for eksempel relateres til hav og himmel, men også til det norske flagget og konservative partier, mens rødt kan relateres til kjærlighet, fare, blod og venstreorienterte partier. Lilla forbindes med advent, rødt med jul og gult med påske. Farger kan ifølge Kress og van Leeuwen (2006, s. 229) «be used to denote people, places and things as well as classes of people, places and things, and more general ideas». Dessuten kan de interagere med 
betrakteren gjennom effekten farger har på mottakeren. Kress og van Leeuwen omtaler fargehandlinger som en parallell til talehandlinger. På den måten kan farger "gjøre» ting som å gi energi, advare, berolige, harmonisere, forstyrre, imponere osv. I alle slike tilfeller skaper farger sosiale relasjoner. I tillegg kan de skape tekstlig kohesjon ved å binde sammen elementer på en bokside eller internettside, på en reklameplakat eller en bygning eller i et rom.

I boka The Language of Colour (2011) tar Theo van Leeuwen opp farger som meningsskaping - både historisk og kulturelt. Han sier at farger kan studeres som et fysisk fenomen som lys og som fargepersepsjon hos mennesker. Han er imidlertid opptatt av «the social science of colour», hvordan et samfunn «(...) uses colour for purposes of expression and communication, whether in art, architecture, fashion, or every days objects», og hvordan farger blir brukt og manipulert «for the expression of feelings, for the communication of ideas, and for social interaction» (van Leeuwen, 2011, s. 1). Når mening knyttes til ulike farger, skjer det i en kulturell kontekst. Historisk var det strenge regler for fargebruk i mange settinger, for eksempel i religiøs sammenheng. Slik er det også på visse områder i dag. For eksempel er farger med på å fortelle om militær rang. I dagens norske samfunn har vi allikevel ikke de samme strenge reglene for fargebruk som tidligere, men det er fremdeles tradisjoner og konvensjoner for hvordan farger skal og kan brukes. Med andre ord - i alle samfunn blir farger tillagt mening. Michel Pastoureau (2008, s. 16) sier: «It is the society that «makes» the colour, that gives it its definition and meanings, that constructs its codes and values, that organizes its customs and determines its stakes.» Tittelen på boka som tas opp i dette kapittelet - Noen sier døden er svart - viser nettopp dette. Den indikerer at noen (men ikke alle) sier at døden er svart. Tradisjonelt er dette sorgens og mørkets farge, men siden det bare er noen som sier at døden er svart, så kan kanskje lysere farger også få spille en rolle. Det er dette forfatter og illustratør spiller på i bildeboka.

I analysen nedenfor blir farge som representasjon, altså hvilke konnotasjoner fargene i boka gir, og farge som interaksjon, altså fargenes effekt, tatt opp. Farge som tekstlig kohesjon blir i liten grad berørt, siden dette er mindre aktuelt i denne bildeboka. Underveis blir fargenes samspill med verbalteksten trukket inn. Det er gjennom språket vi får høre om hvilke 
refleksjoner Alfred gjør seg om fargenes mening. Illustrasjonenes utforming kommenteres ikke systematisk, men trekkes inn i noen tilfeller. Selv om det her fokuseres på farge som meningsskaping, er det oppslaget som multimodal tekst som møter leseren. Boka består av 14 oppslag (sidene er unummerert). Nedenfor tas forsiden og oppslagene én, to, tre, fire, sju, åtte, ti og fjorten opp.

\section{Farger i bildeboka Noen sier døden er svart}

Som nevnt ovenfor er farge en viktig meningsskapende ressurs når Forfang og Auestad skal ta opp døden i boka si. Det er gjennom farger de formidler og problematiserer dette temaet. Formuleringen i tittelen gjør at leserne fra første stund forstår at forfatterne har tenkt å sette spørsmålstegn ved det mørke og svarte ved døden. Tittelen er skrevet med hvite bokstaver med rød innramming på bokas forside (se figur 1 nedenfor), og de sterke røde og oransje fargetonene som danner bakgrunnen for tittelen, skaper en tydelig kontrast til det verbalteksten formidler, nemlig døden som svart. Illustrasjonen viser en hest med rytter i fart mot høyre i bildet, en retning som Kress og van Leeuwen (2006) betegner som bevegelse inn i det ukjente - slik døden jo er for oss alle. Her blir rødfargen mørkere, noe som kan understreke det ukjente, men den er fremdeles sterk rød. Det er ifølge van Leeuwen (2011, s. 58) ikke slik at ulike farger har absolutt mening. De har et meningspotensial som blir realisert på ulike måter i ulike kontekster - og med ulike tradisjoner i kulturen. Derfor er ikke rød automatisk kjærlighetens og gledens farge. Heller ikke er den automatisk et tegn på fare. På denne boksiden er den med på å formidle det som kan oppfattes som hovedbudskapet i boka, nemlig at det er ulike måter å oppfatte døden på. Dette understrekes av innsidepermen, som viser linjer med alle regnbuens farger. Slik nyanserer forfatterne temaet døden fra første stund for leserne. Det er like mange måter å oppfatte døden på som det er farger i regnbuen. Selve illustrasjonen er også med på å understreke dette. Skikkelsen på hesten har pannebånd med fjær og noe som kan oppfattes som frynser på overdel og bukse. Dette er attributter som mange lesere vil forbinde med urbefolkningen i Amerika. Slik antyder også forfatter og illustratør at døden oppfattes ulikt i ulike kulturer. 


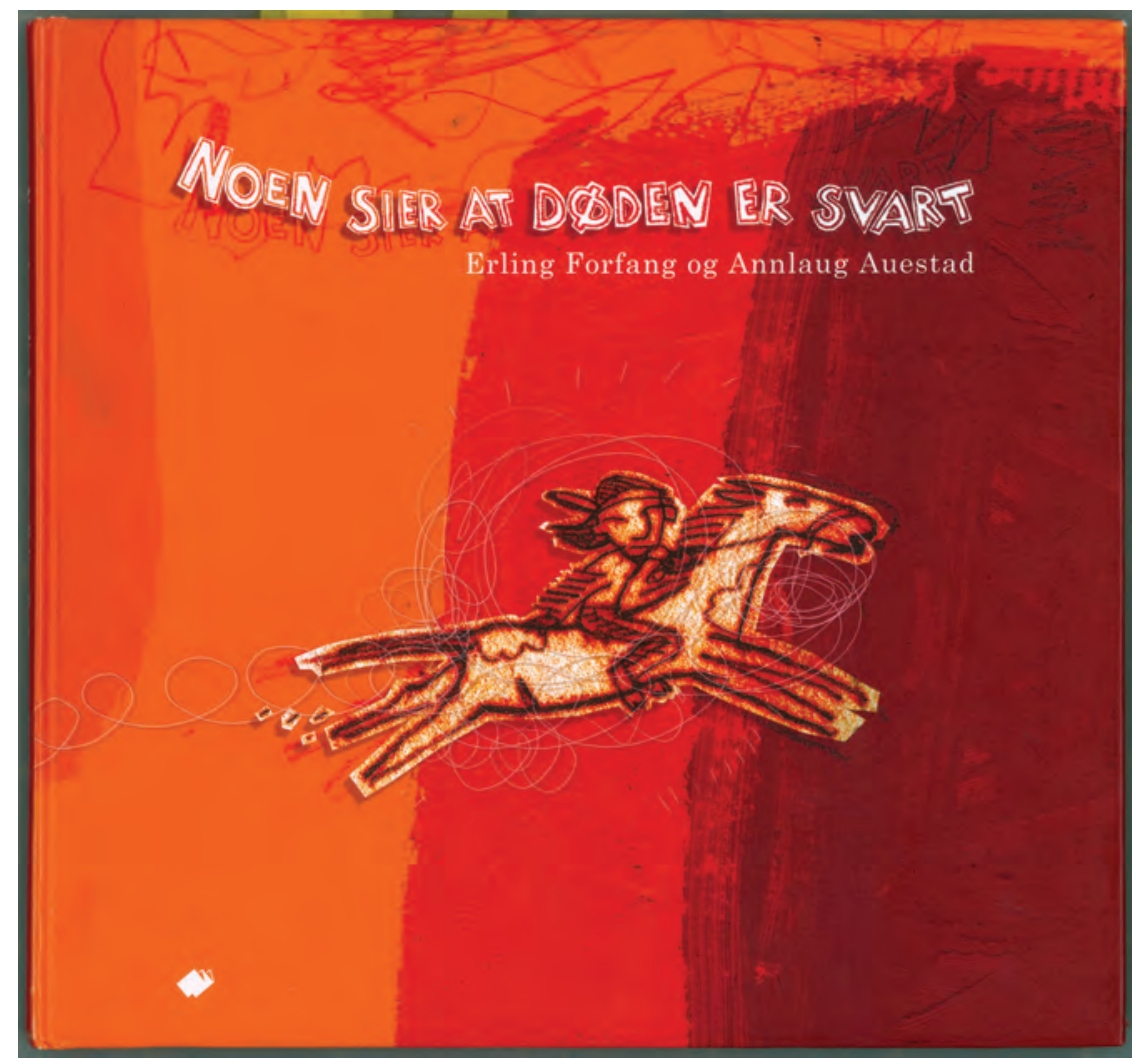

Figur 1: Forsiden til bildeboka Noen sier at døden er svart. Gjengitt med tillatelse fra Annlaug Auestad/Wigestrand forlag.

Gjennom boka undersøkes ulike farger på døden gjennom Alfreds refleksjoner og samtalene han har med Maria i tankene sine. Hver farge får ett eller to oppslag, og gjennom verbalspråk og illustrasjoner bruker Alfred dagliglivets erfaringer til å spekulere på hvordan døden kan være.

\section{Svart}

Den første fargen som tas opp, er svart, og dette og det neste oppslaget danner et utgangspunkt for refleksjonene til Alfred (se figur 2 nedenfor). Venstre side viser en kiste som senkes ned i jorda i en kjegleformet lysstripe. Den går fra lys mot mørke. Høyre side viser en djevleliknende person med horn og klover og med et dramatisk uttrykk i ansiktet. Til høyre i 
bildet går en skikkelse mot det ukjente, og foran skikkelsen er det skrevet INGEN TING med store, utydelige bokstaver ovenfra og ned. Den sorte og grå fargen representerer jord og mangel på lys, og den kommuniserer mørke til leseren. Machin (2007, s. 102) sier at erfaringer med lys og mørke er helt fundamentale: «There is probably no culture that does not have a mass of symbolic meanings and values based on this distinction.» Svart assosieres ofte med død og sorg, og at det å dø er å gå fra lys til mørke. Slik har gjerne svart også spilt en viktig rolle i begravelser. Inntil nylig var det en uskreven regel at folk skulle ha svarte klær i begravelse, og i enkelte samfunn bærer enker svarte klær resten av livet for å markere sorg over ektemannen som har gått bort.

Gjennom ulike toner av grått på oppslaget skapes det også en uro i bildet, noe som understrekes av de dramatiske detaljene i illustrasjonene og de mange strekene som er tegnet inn i bildet. Effekten som fargetonene i samspill med illustrasjonene skaper, er skremmende og foruroligende. Bokas tittel i hvit skrift på venstre side i oppslaget bryter imidlertid med dette dystre budskapet. Den forteller at det jo bare er noen som mener at døden er svart. Ordet «Noen» er skrevet med større bokstaver enn de andre ordene og framhever nettopp at ikke alle tolker døden så skremmende som her. En stiplet linje i en lysere fargetone går fra tittelen og mot den høyre kanten. Den inviterer leseren til å bla om og dermed få alternativer til dette skremmende oppslaget. Dette første oppslaget er utgangspunkt for Alfreds refleksjoner på neste oppslag: «Noen sier at døden er svart. Med svarte menn. Svarte damer. Svarte barn. Svarte klær. Svarte biler. Svarte prester. Svarte natten. Mørk, mørk, mørk! Da er døden ingenting. Alt er borte. Hvis det er sånn, er det ganske trist å dø, tenker Alfred» (oppslag 2). Bjørn, broren til Marie, er død, og kisten ble lagt i mørk jord. Men Alfred slår seg ikke til ro med dette, og spør: «Kanskje døden er rød?» Rød er en varm farge og danner dermed et alternativ til det kalde svarte og grå i oppslaget. Spørsmålet er plassert nederst i høyre hjørne sammen med en liten versjon av hesten med rytteren fra bokas forside. Både illustrasjonen og spørsmålet inviterer leseren til å bla om for å finne ut om døden kan være rød. Slik bidrar rødfargen nederst til komposisjonen i boka. Hver gang leseren blar om, reflekteres det over en ny farge. 


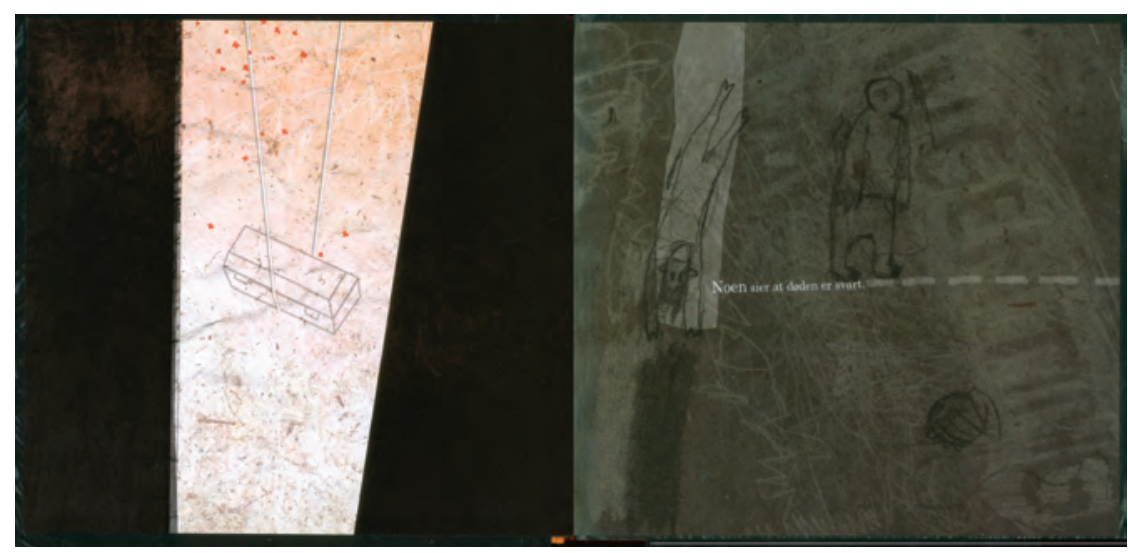

Figur 2: Svart (oppslag 1 fra Noen sier at døden er svart). Gjengitt med tillatelse fra Annlaug Auestad/Wigestrand forlag.

\section{Rød}

På det tredje oppslaget gjentas bildet fra forsiden av boka på høyre side. Samtidig har hesten og rytteren beveget seg inn på oppslaget nederst til venstre og bidrar slik i komposisjonen. Den røde fargen dominerer, og den er mettet uten mange nyanser. Slike mettede farger uttrykker ifølge Machin (2007, s. 102) høy «emotional temperature». Det er flere steder tydelige streker etter pensel og blyant. Slik dannes det ingen naturalistisk bakgrunn for hesten og rytteren, men en tydelig malt flate. Denne måten å framstille farge på går igjen på alle oppslagene ved at hvert av dem delvis er dekket av en farge som tydelig er malt på underlaget. I tillegg er illustrasjonene enkle strektegninger. Derfor har det ikke vært viktig å representere virkeligheten på en naturalistisk måte gjennom fargebruk, maleteknikk og illustrasjoner. Det ser heller ut som måten fargene er representert på, understreker at det dreier seg om tanker, undringer og spørsmål som ikke har klare svar. Den «ujevne» måten å male på og de enkle strektegningene kan også antyde at det ikke bare er Alfreds tanker vi møter i boka, men at det også er hans tegninger; at han i tillegg til å reflektere har tegnet noen av tankene sine.

Alfred knytter fargen rød til glede («Kanskje døden er rød? Og ganske glad og sprø!») og utdyper dette med brannmann, epler, Manchester 
United og indianere (som blir beskrevet som «rødhuder» i cowboybladene han leser). Tankene hans om fargen rød er tatt fra erfaringene han har gjort i dagliglivet. Bare i ett tilfelle er det en forbindelse til naturen, nemlig til røde epler. De andre er knyttet til forbindelsen mellom rød og kulturelle fenomener som brannmenn (klær og biler), fotballklubben Manchester United og framstillingen av urbefolkningen i Amerika i cowboyblader for barn. Som vi har sett ovenfor, sier van Leeuwen (2011, s. 59) at vi i slike tilfeller «derive their (dvs. fargenes - min kommentar) meanings from the ideas we associate with them». Alfred assosierer rødt med positive elementer i livet sitt, og denne fargen bidrar dermed til en langt lysere atmosfære enn stemningen fra forrige oppslag. Kress og van Leeuwen (2006, s. 235) sier følgende: «... although «the» meaning of red-in-general, of the abstract signifier «red», cannot be established, the red end of the scale remains associated with warmth, energy, salience, foregrounding ...». Alfred er også klar over at det er flere sider ved rødt, for han tenker på at flere fotballspillere fra Manchester United en gang døde i en flyulykke, og at mange indianere er blitt drept. I samspillet med verbalspråket kommuniserer rødfargen derfor mest positivitet, men også noe forstyrrende gjennom flystyrt og drap.
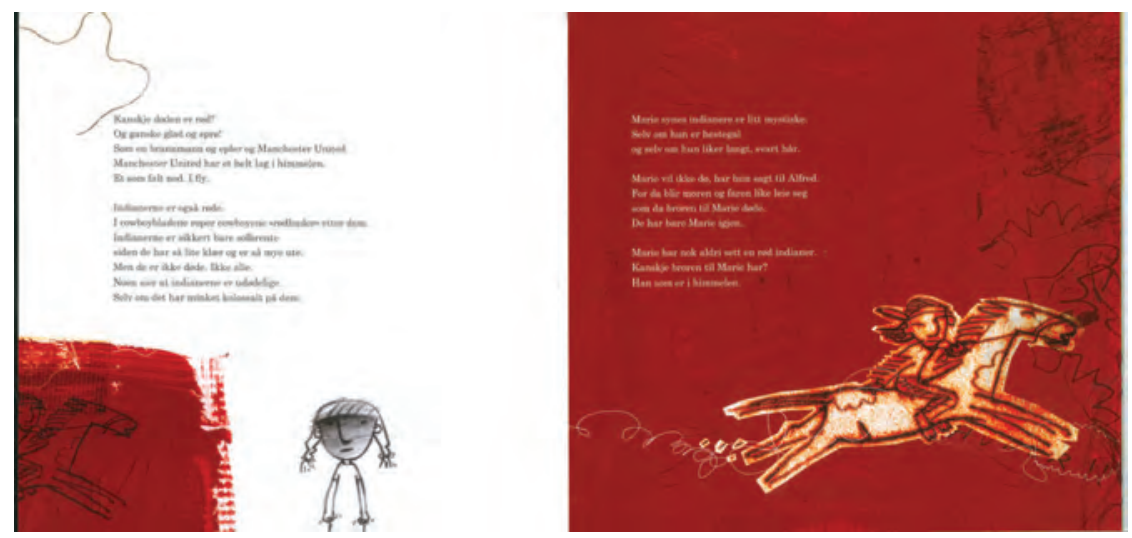

Figur 3: Rød (oppslag 3 fra Noen sier at døden er svart). Gjengitt med tillatelse fra Annlaug Auestad/Wigestrand forlag. 


\section{Grønn}

Fargen grønn får to oppslag, oppslag 4 og 10. På oppslag 4, som skal kommenteres her, er grønnfargen lys og nærmest gulaktig. Grønn er en farge som i vår kultur forbindes både med noe positivt og noe negativt. Det negative er gjerne knyttet til sjalusi, sykdom og noe usunt, noe for eksempel Edvard Munch har utnyttet i sine bilder. Men grønt er også naturens farge, og den har dermed et stort potensial for å representere noe positivt. Grønt forbindes i verbaltekst og illustrasjon på dette oppslaget med «en sommereng med markblomster». Sommer er den lyse årstiden i vår del av verden, og årstiden er gjerne forbundet med noe positivt i nordisk kultur. I verbalteksten og illustrasjonene blir døden knyttet til det å ligge på ryggen i gresset og se på himmelen. Dette vises også i illustrasjonen der ei jente som vi forbinder med Marie, Alfreds venninne, ligger som i en seng av grønt gress omgitt av sommerfugler og humler (ifølge verbalteksten). På Alfreds T-skjorte står det skrevet SOL, og på oppslagets venstre side er det skrevet «Evig sol» med barnlig løkkeskrift. Disse verbalspråklige tekstene, sammen med den lyse grønnfargen, understreker lyset i oppslaget. I vår kultur sier vi dessuten ofte at håpet er lysegrønt, noe som kan ses i sammenheng med våren og de lyse fargene som representerer det nye i positiv forstand. Slik blir overgangen til døden knyttet til håp og ikke til fortvilelse og mørke. Grønt gress trekkes over på positive erfaringer og følelser Alfred har for sommeren, og skaper en lys og lett atmosfære som står i sterk kontrast til det dystre, første oppslaget i boka. Sommeren gir barn muligheter til lek og aktiviteter, til en følelse av frihet og glede. Har vi gode barndomsminner, kan vi nettopp si «grønn var min barndoms dal». Igjen forbindes grønt med noe positivt. Det skaper også en forbindelse til Bibelens Salmenes bok 23,1-3, der det blant annet står: «Han lar meg ligge i grønne enger» (se dessuten nedenfor i avsnittet om regnbuen). Lyse farger bidrar generelt til en lys og lett stemning ifølge Machin (2007, s. 102). Denne stemningen forbindes videre til slik det kanskje er i himmelen, men igjen kommer noe forstyrrende inn: «Det er kanskje derfor noen tar snarveien?» Alfred utdyper ikke dette, men det ligger under at altfor positive bilder av hvordan det er i himmelen, kan gjøre at noen avslutter livet sitt. 


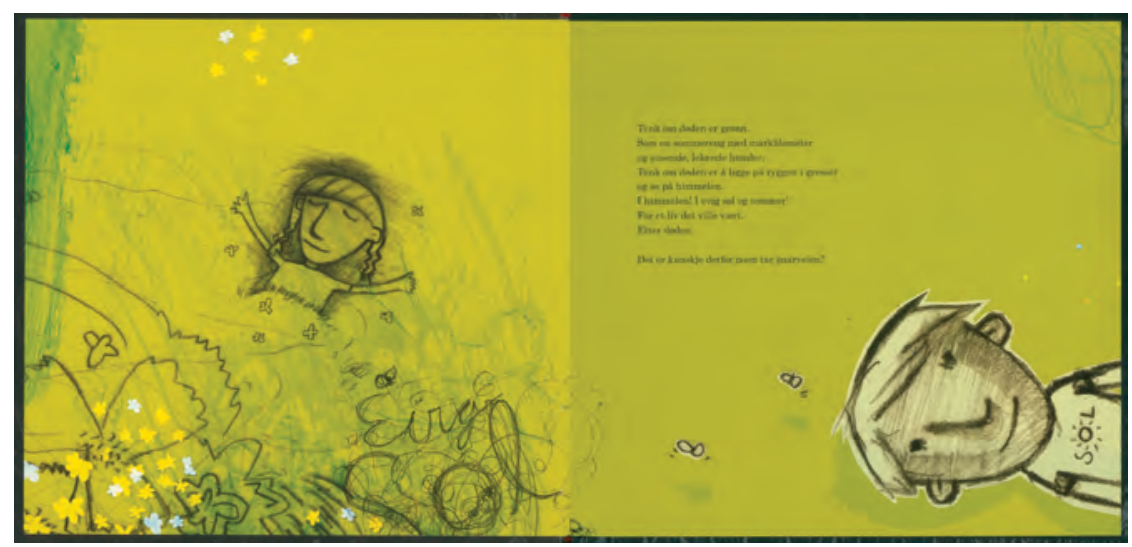

Figur 4: Grønn (oppslag 4 fra Noen sier at døden er svart). Gjengitt med tillatelse fra Annlaug Auestad/Wigestrand forlag.

\section{Gul}

Gul er fargen på oppslagene 7 og 8. Oppslag 7 skiller seg ut fra de andre oppslagene i boka. Det består av en eneste stor sol som både kan minne om Munchs sol i Universitetets aula i Oslo og slik barn tegner sol. Selve solen er guloransje med oransje sirkler, og strålene som strekker seg ut over begge sidene i oppslaget, er klarere gule med innslag av grønt. Når vi ser på solen, ser den gul ut, og det er en konvensjon å male og tegne solen gul. Fargen gul forbindes også ofte med lys. Ifølge Machin (2007, s. 102) gir gjerne det lyse en atmosfære av klarhet og glede. Gult og oransje er også i den «varme» delen av fargeskalaen (Kress \& van Leeuwen, 2006, s. 235), og gult representerer ofte kraft og energi. På en av solstrålene står det: "Hvis døden er gul, vil den skinne som solen» (og solen er framhevet med større font). Inne i solen på høyre side er det tegnet en manns ansikt. Mannen har langt hår og skjegg, og framstillingen minner om slik Jesus ofte er framstilt på bilder. Slik blir solen, den lyse atmosfæren og Jesus knyttet sammen. På neste oppslag reflekterer Alfred videre: «Solen er selve livet. Evig og for alltid. Evig, gul sol.» Han synes det med evighet passer bra, for er man død, så er man død til evig tid. Videre forbinder Alfred gult med påske, med kyllinger og egg og små gule flekker i snøen. Med påsken er det lett å trekke forbindelser til døden, for da er det jo mye død, sier han. Igjen bygger refleksjonene hans på en naturalistisk representasjon, ved at både kyllinger 
og eggeplommer er gule, men samtidig har gulfargen en helt spesiell kulturell betydning som påskens farge. Den er ikke knyttet til religiøse påskeritualer, selv om Judas ofte er representert i gule klær. Kirkens farger er fiolett fram til langfredag og hvit fra og med påskeaften. Alfred forbinder også gult med månen, og at noen sier at månen er en gul ost (se verbalteksten). Han sier at månen får det gule lyset sitt fra sola, men samtidig tolker han månen som et stoppested til himmelen, og det er der sola er. Da blir gulfargen noe mer, og den religiøse forestillingen om det gylne og skinnende lyset i himmelen kommer fram, det van Leeuwen i sin bok om farger benevner som «the divine light» (van Leeuwen, 2011, s. 59). Slik blir disse to oppslagene de som kanskje i aller størst grad viser det underliggende kristne budskapet i boka.

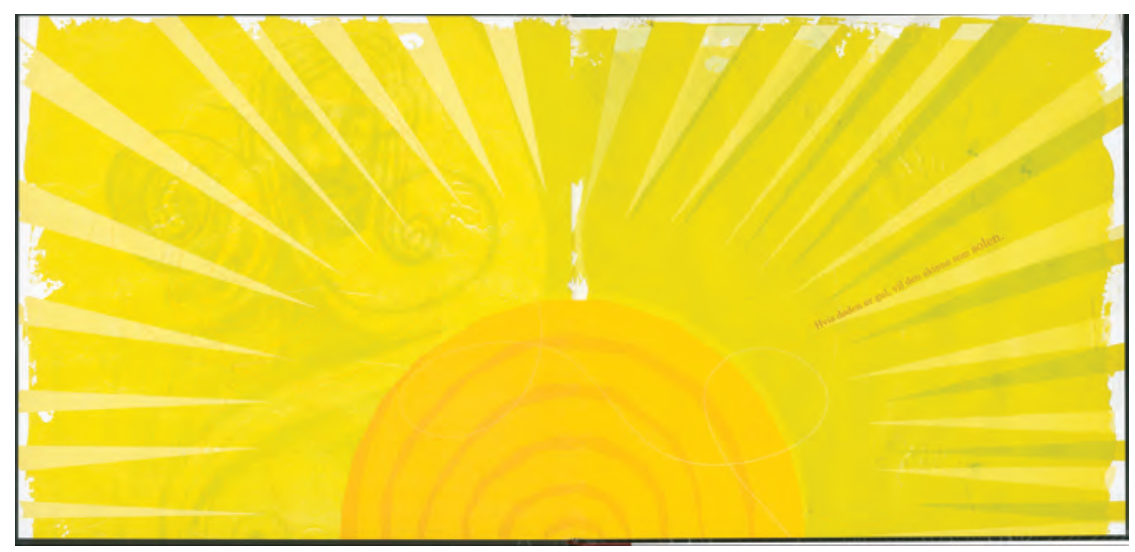

Figur 5: Gul (oppslag 7 fra Noen sier at døden er svart). Gjengitt med tillatelse fra Annlaug Auestad/Wigestrand forlag.

\section{Rosa}

Fargen rosa har bare fått ett oppslag. Den venstre siden har en mørkere farge enn den høyre. Her står verbalteksten, og nederst i hjørnet er det en liten illustrasjon av en gutt med et litt rampete smil. Gutten tolkes som Alfred. Det går en snakkeboble ut fra ham: «Jentefarge» (se figur 6). På den høyre siden er det en tegning av jenta som går igjen i bildeboka, altså Marie. Her er fargen lys og klar rosa, og slik blir rosa hennes farge. Rosa forbindes ofte i vår kultur nettopp med det feminine, og med noe som er søtt og yndig. Veronika Koller (2008, s. 396) sier følgende ut fra en 
undersøkelse hun gjorde i Storbritannia om oppfatninger av fargen rosa: «Thus, it (pink - min anmerkning) is, unsurprisingly, connected with femininity and its stereotypical features, such as softness and delicacy, with childhood and innocence as well as with vanity and artificiality.» Å være søt og yndig er derimot egenskaper som de fleste smågutter ikke ønsker å bli forbundet med. Småjenter, derimot, oppdras ofte til å være både søte, yndige og sarte. De ønsker seg rosa klær og leker, og de tegner ofte med rosa fargestifter. Mange små jenter vil dessuten si at rosa er yndlingsfargen deres. Rosa som jentefarge er selvsagt en kulturell konvensjon, og den følges ofte opp av voksne som for eksempel innreder jenterommet med rosa vegger, gardiner osv.

Alfred har ulike tanker om rosa. På den ene siden er han preget av samfunnets oppfatning av fargen: «Alfred synes rosa er jentete. Barbie! sier han og grøsser. Kjoler! Sløyfer! Æsj.» Men samtidig er han glad i Marie, og hun er jo jente med rosa farger. Han assosierer rosa også med solnedgangen, og solnedgangen kan forbindes med å dø. Derfor slår Alfred fast: «Døden er nok rosa. Som en solnedgang.» Refleksjonene til Alfred viser nettopp at en farge som rosa har et stort meningspotensial, og at den også kan, når han tenker etter, forbindes med døden. I likhet med rød befinner rosa seg i den «varme» enden av fargeskalaen, noe som gjør at dette oppslaget gir en varm og positiv effekt. Døden får igjen en mer positiv framstilling enn slik det første oppslaget viste.

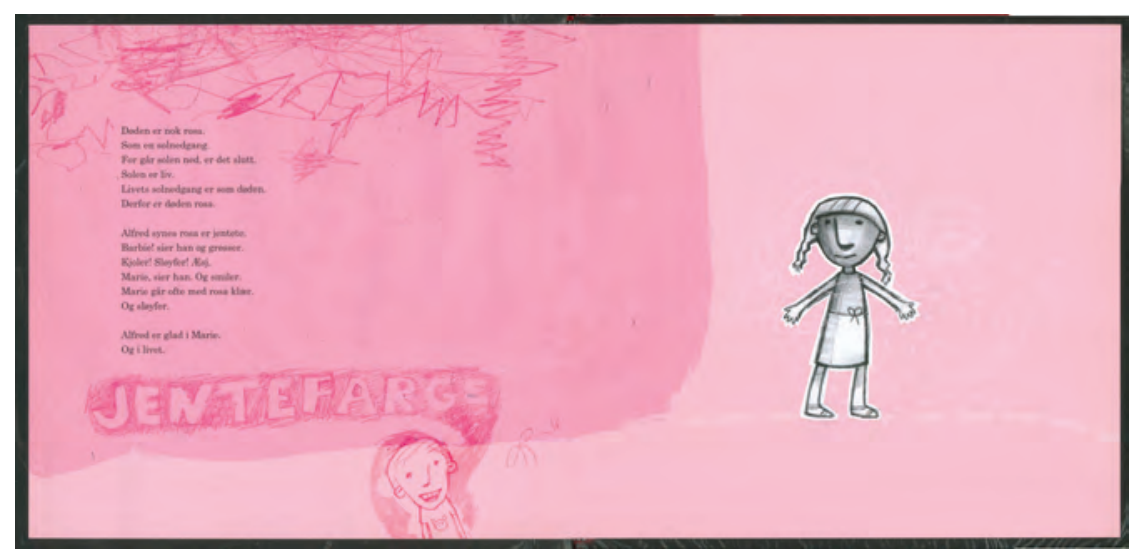

Figur 6: Rosa (oppslag 9 fra Noen sier at døden er svart). Gjengitt med tillatelse fra Annlaug Auestad/Wigestrand forlag. 


\section{Regnbuen}

Allerede på innsidepermen blir det klart at alle regnbuens farger er viktige i boka, og at døden dermed kan forbindes med mange farger og gjennom disse bli tolket på mange ulike måter. Regnbuen tas opp igjen på det siste oppslaget, oppslag 14 (se figur 7) nedenfor. Den kommer nettopp som en bue inn på nedre del av den venstre siden av oppslaget. På den høyre siden er det den samme illustrasjonen som på forsiden og på de første oppslagene i boka, nemlig av hesten som løper i stor hastighet mot høyre, altså mot det ukjente, med rytteren oppå. Men det er en forskjell i framstillingen. Mens rytteren på forsiden har lukkede øyne og et uttrykksløst ansikt, ser han nå glad ut. Øynene er åpne, og han smiler. Bak ham som en fartsstripe står det «... ses Marie...», skrevet med samme barnlige skrift som tidligere. Bak illustrasjonen er det tegnet inn mange uregelmessige blå streker, og siden blått kan assosieres med luft, er det som om hesten og rytteren svever i lufta. Dette understrekes også av den hvite linjen under hesten som markerer at bakken er et stykke under dem. Hesten og rytteren er tegnet med en gyllen strek og er ellers hvit. Dette er helt andre farger enn tidligere. Det hvite spiller sammen med det blå og understreker det luftige, og den gylne streken fanger opp fargen fra sollyset tidligere i boka. Bakgrunnen er beige, og den blir lysere på høyre side, der hesten og rytteren er tegnet inn. Regnbuens farger samt fargene hvit, lys beige og gyllen gir et lyst, positivt og svært annerledes bilde av døden enn i det første oppslaget. Kanskje er det ikke bare mørke som omgir døden, men også noe lyst, en fortsettelse på den andre siden. Dette er som sagt bokas hovedbudskap, og det kommer tydelig fram på dette siste oppslaget.

Teksten på høyre side av oppslaget understøtter dette budskapet. Den formidler tydeligere troen på et liv etter døden enn det tekstene på de andre oppslagene gjør, og den står som et resultat, en slags konklusjon, fra Alfreds side etter alle refleksjonene han har gjort på de andre oppslagene: «Han (dvs. Bjørn, Maries bror, som døde - min kommentar) rir til et annet sted, et sted der alt er annerledes enn det vi er vant med. (...) På en grønn eng, kanskje. Med en regnbue til port! Et sted det ikke går an å dø fra. Til livet etter døden.» Slik blir det mulig for barnet Alfred å takle at Bjørn ikke er mer. Han har ridd til et annet sted, og han har det bra. Fargene er viktige for å få fram dette budskapet. Den stadig lysere 
bakgrunnen ut mot høyre side i oppslaget og de lyse fargene på rytter og hest formidler denne atmosfæren på en effektfull måte. Regnbuen tolkes inn i dette som porten inn til det andre stedet. Det snakkes ikke om himmel her og ikke om Gud, men bibelassosiasjonene er tydelige. «Grønn eng» gir, som vi også har sett ovenfor, assosiasjoner til Salmenes bok 23, 1-3, der det står: «Herren er min hyrde, jeg mangler ingen ting. Han lar meg ligge i grønne enger.» Regnbue som port gir assosiasjoner til de tolv perleportene i Johannes, åpenbaring 21,21 som inngangen til himmelen.

Men teksten gir også en annen konklusjon. Alfred reflekterer: «Marie sier av og til at broren er en død indianer. Indianeren Sovende Bjørn. Og Sovende Bjørn rir på en hvit hest. Inn i solnedgangen. Inn i evigheten.» Slik blir Bjørn til rytteren på hesten, og vi forstår at refleksjonene til Alfred har utgangspunkt i et forsøk på å komme til rette med det ufattelige i at et barn som han og Marie er død. Fargene, med deres meningspotensial, blir hjelpemidler for Alfred i denne prosessen.

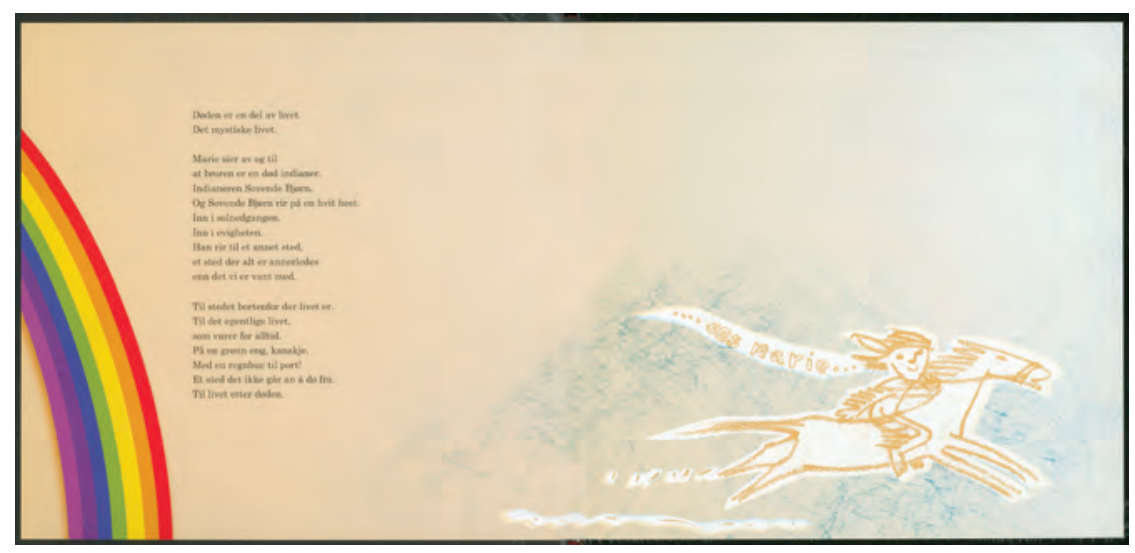

Figur 7: Regnbuen (oppslag 14 fra Noen sier at døden er svart). Gjengitt med tillatelse fra Annlaug Auestad/Wigestrand forlag.

\section{Oppsummering}

I bildeboka Noen sier at døden er svart er fargers meningspotensial viktig. Gjennom refleksjoner knytter Alfred forbindelser mellom døden og ulike farger. Fargene representerer egenskaper ved naturen (røde epler, grønne enger, gul sol, gul måne, rosa solnedgang, m.m.) samt ting og fenomener i 
verden rundt ham (rødt for Manchester United, grønt for håpet, rosa for jenter, m.m.). Fargene hjelper ham å komme til rette med at broren til Marie, Bjørn, er død. Alfred forbinder begravelsen der kista senkes ned i jorda og går fra lys til mørke, med noe skremmende, men ved hjelp av andre farger og fargene i regnbuen kan han konkludere med at Bjørn rir inn i solnedgangen til evigheten, og at det allikevel er det lyse som omgir ham. I interaksjonen med leseren gir de ulike fargene svært ulik atmosfære. Effekten av fargebruken går fra det dystre og mørke til lys og harmoni. Alfreds refleksjoner utnytter meningspotensialet til fargene. Eller som van Leeuwen (2011, s. 58) sier: «It is important to emphasize that colours have meaning potentials (or metaphor potentials) rather than specific meanings, and that these meaning potentials will only be narrowed down, made more specific, in specific cultural and situational contexts.» Det er dette Alfred gjør når han i sin kontekst og ut fra sin forestillingsverden ser hvordan farger kan skape mening for ham. Men Alfreds tanker om fargene er ikke bare private. Vi kjenner dem igjen fra hvordan vi skaper mening med farger i vår kultur. Dermed er det lett for barnelesere og andre lesere å følge Alfreds fargeassosiasjoner og den stemningen og atmosfæren som Painter mfl. sier at farger skaper (se ovenfor).

I nyere bildebøker for barn der døden er tema, kan døden være framstilt konkret og direkte, slik som for eksempel i Farvel, Rune (se innledningen), men både i denne boka og i de andre bøkene som er nevnt innledningsvis, er det også typisk at døden er forbundet med en lysere stemning, en stemning av håp. Forfatterne og illustratørene får fram den lyse stemningen på ulike måter. Iben Sandemose bruker, som nevnt tidligere, humor i sin framstilling, mens både Stian Hole og Gaute Heivoll og Øyvind Lauvdahl bruker drømmeaktige bilder om enn på svært forskjellige måter. I Forfang og Auestads bok er det fargene og deres meningspotensial som utnyttes for å skape håp. Forfang og Auestads bok skiller seg dessuten ut fra de tre andre ved at perspektiver er lagt fullt og helt til barnet og barnets refleksjoner om døden og det som kommer etterpå. Det finnes ingen voksne bipersoner som barnet samhandler med. Slik blir fargenes betydning og meningsskaping knyttet til barnets verden. Fargene blir en semiotisk ressurs for barnet til å «ordne opp» i en kaotisk verden forbundet med vennen Bjørns død.

Hensikten med dette kapittelet har vært å se nærmere på hvordan farger blir viktige i meningsskapingen om døden i bildeboka Noen sier 
at døden er svart, og hvordan de blir en ressurs i et barns refleksjoner om noe så abstrakt og kompleks som det som måtte komme etter døden. Hensikten har også vært å si noe mer generelt om farger som semiotisk system. Farger er ofte bare der; vi ser verden rundt oss i farger hele tiden, men de har mening. De er med på å representere verden rundt oss og $\mathrm{i}$ oss, og de interagerer med oss ved å bidra til stemning og atmosfære.

\section{Referanser}

Forfang, Erling, \& Auestad, Annlaug (2006). Noen sier at døden er svart. Stavanger: Wigestrand Forlag.

Halliday, Michael A. K. (1978). Language as Social Semiotics: the Social Interpretation of Language and Meaning. London: Edward Arnold.

Halliday, Michael A. K., \& Matthiessen, Christian M. I. M. (2014). Halliday's Introduction to Functional Grammar. $4^{\text {th }}$ Edition. London: Routledge.

Heivoll, Gaute, \& Lauvdahl, Øyvind (2008). Himmelen bak huset. Oslo: Damm.

Hole, Stian (2013). Annas himmel. Oslo: Cappelen Damm.

Kaldhol, Marit, \& Øyen, Wenche (1986). Farvel, Rune. Oslo: Samlaget.

Koller, Veronika (2008). «Not just a colour»: Pink as gender and sexuality marker in visual communication. Visual Communication 7, 395-423. https://doi. org/10.1177/1470357208096209

Kress, Gunther, \& van Leeuwen, Theo (2001). Multimodal Discourse. The Modes and Media of Contemporary Communication. London: Bloomsbury Academic.

Kress, Gunther, \& van Leeuwen, Theo (2006). Reading Images: The Grammar of Visual Design. London: Routledge.

Machin, David (2007). Introduction to Multimodal Analysis. London: Bloomsbury Academic.

Ommundsen, Åse Marie (2016). Billedbøger mellem læsere. Kontroversielle billedbøger i Norge og Danmark. Passage. Vol. 75, 29-48. https://doi.org/10.7146/ pas.v31i75.24164

O’Toole, Michael (1994). The Language of Displayed Art. London: Leicester University Press.

Painter, Clare, Martin, Jim R., \& Unsworth, Len (2013). Reading Visual Narratives. Image Analysis of Children's Picture Books. London: Routledge.

Pastoureau, Michel (2008). Black - The History of a Colour. Princeton NJ: Princeton University Press.

Sandemose, Iben (2014). Fiat, farmor og den hvite loven. Oslo: Cappelen. van Leeuwen, Theo (2011). The Language of Colour. An Introduction. London: Routledge. 


\title{
Barnet som morder i Karin Fossums forfatterskap
}

\author{
Bente Aamotsbakken \\ Universitetet i Sørøst-Norge
}

\begin{abstract}
Summary: Barnet som morder (The Child as a Murderer) is dealing with two novels written by Karin Fossum: He Who Fears the Wolf (1997) and The Caller (2009). In the novels a neglected young boy, Kannick, and a teenager, Johnny, both commit cruelties and deadly crimes. Kannick's murderous acts are caused by fear and spontaneity in addition to accidental circumstances, whereas Johnny slowly and intentionally plans his actions. However, Johnny has not foreseen that one of his actions causes the death of a small child. Both young boys, Kannick and Johnny, have suffered negligence from their parents. Kannick's mother focuses on her own life and happiness and places her son in an institution. Johnny's mother is heavily addicted to alcohol and refuses to reveal the identity of Johnny's father. The result of lack of care and attention has fatal consequences. Kannick is compensating his miserable life by overeating and lying. He kills an old woman as he tries to steal her purse. This act is spontaneous, and he lies to the police about the circumstances. Johnny, on his side, keeps a small community in fear and desperation as he plans unpleasant and cruel acts such as spilling blood over an innocent sleeping baby, letting the dogs out of their cage, reporting a fake car accident and tormenting a couple dealing with a serious illness. Karin Fossum sheds light on the causes behind the criminal acts more than concentrating on the crime itself. It is the question of why more than of who or how.
\end{abstract}

Keywords: parental negligence, spontaneity, traumatic childhood, unintentional acts

\section{Innledning}

Når vi fødes, er vi uten skyld, uten ansvar. Når vi vokser opp, møter vi krav om medmenneskelighet, empati og deltakelse i samfunnet. Ikke alle barn og unge er beredt til å møte slike fordringer. I Karin Fossums forfatterskap omhandles ofte voksen-barn-relasjonen på måter som viser barns sårbarhet og avhengighet av voksne personer. Innledningsvis kan romanene Se deg ikke tilbake (1996), Svarte sekunder (2002), Den som

Sitering av denne artikkelen: Aamotsbakken, B. (2018). Barnet som morder i Karin Fossums forfatterskap. I A. Johannessen, N. Askeland, I. B. Jørgensen \& J. Ulvestad (Red.), Døden i livet (Kap. 11, s. 189-205). Oslo: Cappelen Damm Akademisk. https://doi.org/10.23865/noasp.40.ch11

Lisens: CC BY-NC 4.0 
elsker noe annet (2007), Carmen Zita og døden (2013) og Helvetesilden (2014) nevnes som eksempler på tematikker der barn utsettes for overgrep og grove forbrytelser fra voksenpersoner. Ytterligere én roman av Fossum har et liknende motiv, barn som overgripere, men der dreier det seg om skjødesløshet og frykt som årsak til død snarere enn en villet, overlagt handling. Et sideplott i Den som elsker noe annet (2007) går ut på at et barn stenges inne i en jordkjeller av kamerater - og etterlates der til han dør. Tematikkene danner så vel intratekstuelle som intertekstuelle forbindelseslinjer mellom romanene og bevirker at de framstår som en helhet innenfor forfatterskapet (Agger, 1999; Agger \& Waade, 2010; Allen, 200o). Overfallsmenn og drapsmenn er i disse romanene karakterisert ved at de er pedofile, voldskriminelle eller at de mangler omsorgsevne. I dette kapittelet vil jeg omtale to andre kriminalromaner av Fossum der et barn eller en ungdom blir drapsmann. Det dreier seg om Den som frykter ulven (1997) og Varsleren (2009). Et gjennomgangstema i begge disse bøkene er omsorgssvikt og medfølgende traumer (Meyhoff, 2009; Skei, 2008). De to romanene skal leses med det for øye å finne fellestrekk og mulige ulikheter når det handler om å forårsake død. Barndommen og ungdomstidens betydning vil bli tillagt vekt, men også omgivelsenes innvirkning blir trukket inn i analysen. Hva kan en traumatisk barndom med omsorgssvikt og manglende voksenkontakt føre til i ungdomstiden og voksentilværelsen? Én antakelse er at en belastet barndom kan føre til avstumpethet og manglende empati senere i livet. For hovedpersonen i en av romanene er dette tilfellet. Videre er det interessant å spørre om kriminelle handlinger utført av barn eller svært unge personer skjer som resultat av listig planlegging eller av rene tilfeldigheter. En antakelse er at så vel uhell som tilfeldigheter kan spille inn, slik at en uskyldig aktivitet kan forårsake ødeleggelse og død uintendert og brått. Dette gjelder for den andre romanen - med en tolvårig gutt i sentrum.

Eksakt planlegging og sterk intensjonalitet er karakteristika som hefter ved voksnes drap og forbrytelser. I de to valgte romanene kommer døden både som uhell, tilfeldige omstendigheter og uforklarlige hendelser. Like fullt oppleves den som smertelig, urettferdig og uopprettelig av dem som rammes. Døden akkompagneres uten unntak av personlige tragedier, oppløsningstendenser og ødelagte liv. 


\section{Barnets krav på omsorg}

Ifølge FNs barnekonvensjon har alle barn krav på omsorg, og i paragraf 9 understrekes følgende: «Barnet skal ikke adskilles fra sine foreldre mot sin vilje, unntatt når dette er nødvendig av hensyn til barnets beste.» For den tolvårige Kannick i Den som frykter ulven er nettopp adskillelsen fra moren og plasseringen i barnehjem situasjonen. Hva dette må ha avstedkommet av sorg, savn og traumer for gutten, ses i hans konstante behov for oppmerksomhet. For tenåringsgutten Johnny i Varsleren er imidlertid personer i nærmeste familie til stede i livet hans. Moren sover jevnlig ut rusen på den nedslitte sofaen i det ustelte rekkehuset, og gutten har et uttalt hatforhold til henne. Bestefaren er derimot både en person gutten kan betro seg til, og en person han kan vise empati og omsorg overfor. I dette tilfellet fungerer bestefaren nærmest i foreldrenes sted, men siden han er svekket av sykdom og dårlig til beins, skapes en gjensidig avhengighet mellom de to. Johnny hjelper den gamle med daglige gjøremål som å handle i butikken, lese høyt fra avisen og lage litt mat, mens den eldre mannen forstrekker ham med noen kroner og byr på muligheter for gode samtaler. Johnny lever derfor på en grense mellom kjærlig omsorg og total neglisjering.

Unni Langås skriver i boken Traumets betydning i norsk samtidslitteratur om ulike former for traumer slik litteraturen behandler det (Langås, 2015). Hun skiller mellom rutinemessige, narrative og traumatiske minner, der det første handler om internaliserte adferdsmønstre, det andre om affektive opplevelser og det tredje om fortidige hendelser som vedvarende dukker opp i bevisstheten og forstyrrer den normale livsførselen. For gutten Kannick sitter traumene knyttet til barndommen dypt, men på overflaten er de mindre merkbare. Hendelser knyttet til neglisjering i barneårene plager ham, men han vet å kompensere i hverdagen. Gutten fungerer tilsynelatende på lik linje med de andre barna på barnehjemmets avdeling for gutter, men ifølge personalet har han en lei tendens til å lyve. Kannick er sensasjonslysten og ønsker å bli lagt merke til, og derfor pynter han på sannheten ved å legge til dramatiske poeng i det han forteller. Når han kommer til politistasjonen for å si fra om at den eldre enken, Halldis Horn, ligger død på trappa til huset sitt, blir han i første omgang ikke trodd. Han er kjent for sine løgner, som de voksne rundt ham ser som 
en kompenseringsmekanisme for en trist barndom. Den lokale lensmannen er derfor skeptisk, men førstebetjent Konrad Sejer tar ham derimot på alvor. Ved ankomst til åstedet for handlingen er det åpenbart at den tolv år gamle gutten har rett. Denne gangen har han fortalt sannheten. Den eldre damen ligger drept på trappa med en ugresshakke dypt $\mathrm{i}$ øyet.

For den syttenårige Johnny i Varsleren er hans karakteregenskaper mer obskure og vanskelige å forholde seg til for omverdenen. Johnny er varsleren, varsleren som bringer forskrekkelse, angst og sorg til sine ofre. Handlinger av utspekulert slag som det å stenke dyreblod over en uskyldig, sovende baby, sette inn en falsk dødsannonse i lokalavisen, sende en likvogn til et hjemsøkt ektepar, gi et falskt varsel om en alvorlig trafikkulykke og plage en jente i nabolaget, er noe av det han tilbringer ellers innholdsløse dager med. Sett i relasjon til fortellingen om den tolvårige barnehjemsgutten Kannick er Johnny som protagonist mer kompleks. Dette har med aldersdifferansen mellom de to å gjøre: Kannick er ennå bare et barn, mens Johnny er på vei mot voksenlivet. Barn kan imidlertid også være onde og fulle av destruktivitet. En allmenn oppfatning om at barn er uskyldige og snille, gjelder i mange sammenhenger, men som voksne vet vi at ikke alle faller inn under en slik karakteristikk. Barn kan være grusomme, de kan lyve og være utspekulerte. Både Kannick og Johnny er slike barn.

Oppfatningen om at også barn kan være onde, er en arv fra den kristne reformasjonen. Troen på arvesynden gjorde at barnet ble ansett som Guds skjøre skapning og måtte beskyttes. Fordi mennesket var født ondt, måtte det rettledes og opplyses. Opplysningstiden, med den britiske filosofen John Locke, snudde om på denne oppfatningen idet hans «tabula rasa»-begrep kom i spill. Barnet var da å anse som «et blankt ark» som skulle fylles av foreldre og samfunnet. Med filosofen Jean-Jacques Rousseau ble synet på barnet på 1700-tallet endret til at barnet trengte rettledning for å kunne modnes til et voksent, ansvarlig menneske. Det viser seg at oppfatningen av barnet som enten uskyldig og skjørt eller et individ som er født ondt, endrer seg fra epoke til epoke. I moderne tid forsøker man å forstå barn ved hjelp av ulike typer forskning, og både behaviorisme og Vygotskijs teorier om tenkning og tale har vært grunnleggende (Cunningham, 2006). 


\section{Traumets konstituering i barndomsårene}

Kannick er resultatet av en one-night-stand moren hadde med en polsk mann. Hun er ikke interessert i sitt avkom og ute av stand til å gi gutten nødvendig omsorg. Da Kannick blir spurt om moren lever, kan han svare ja, men:

Han ble sittende og tenke på mora, som han bare så en sjelden gang. [...] Det var vanskelig å huske ansiktet hennes, de snakket aldri så mye sammen. Mora så ham egentlig ikke, bare av og til i korte glimt, og da skvatt hun til og rygget unna i ren forskrekkelse. (Fossum 1997, s. 224)

Mens hans sitter og reflekterer, kommer han på en episode fra barndommen. Moren så en dag plutselig annerledes og bedre ut med mye lengre hår. Det viser seg at hun har kostet på seg påsveiset hår, tretti centimeter lengre enn tidligere. Gutten forsøker å lugge henne i det nye håret, og hun blir rasende og kaller ham idiot. Hun har ikke bare tatt seg råd til å forlenge håret, men foretatt neglestøping og «betalt kroner to tusen tre hundre» (s. 225). Da Kannick påpeker at den summen hadde vært nok til en sykkel, noe «alle andre» har, er reaksjonen:

- «Ligg unna mine saker», ropte hun tilbake. «Du trenger en far som kan holde styr på deg. Jeg får ikke tak i en real mann hvis jeg ser ut som en heks. Jeg må ordne meg litt. Det er for din skyld.» (s. 226)

Kannick har havnet på institusjonen Guttebakken, der sosialarbeideren Margunn viser guttene stor omsorg. Det er likevel ikke nok til å bringe Kannick på rett kjøl. Han har et vanskelig forhold til sannheten, føler seg underlegen og har spist seg opp til å bli usannsynlig fet. Det eneste han behersker bedre enn andre, er å skyte med pil og bue. Institusjonen har derfor investert i skikkelig bue og dyre piler slik at han ved hjelp av en instruktør kan trene til deltakelse i norgesmesterskapet i bueskyting. Det er denne fritidsinteressen som setter ham i stand til å streife rundt i området og skyte på det som kommer i hans vei. Hans dødelige våpen er imidlertid ikke det som blir anvendt som mordvåpen. Det er derimot det praktiske arbeidsredskapet som gamle Halldis Horn arbeider med i hagen. Planen om et simpelt tyveri av en lommebok som ligger i Halldis' 
brødboks, feiler. Kannick blir oppdaget, og han støter ugresshakka dypt i øyet hennes.

For unggutten Johnny, som er varsler i stort omfang, er forbrytelsene flere og preget av sluhet, list og ondskap. Johnny planlegger nøye det som skal skje, og han får ut mange av sine innestengte hevntanker og store frustrasjoner gjennom handlinger som virker opprivende og angstframkallende for flere mennesker i nabolaget hans. Johnny er utspekulert, men er samtidig sammensatt og ikke uten evne til empati og omtanke. Det viser seg i forholdet til bestefaren. Det står i skarp kontrast til forholdet til moren, som han forakter og viser aggresjon overfor.

Johnnys stadige ondskapsfulle påfunn koster i siste instans et lite barn livet. Den lille nederlandske gutten Theo Bosch, som bønnfaller sine foreldre om å få lov til å gå alene på skogtur, møter en ustyrlig hundeflokk som har sluppet ut gjennom en åpnet dør til hundegården. Den som har åpnet døra, er med all tydelighet Johnny, selv om dette ikke sies direkte i romanen. Dermed blir Varsleren en roman som rommer en dobbelthet med hensyn til barn som offer. Johnny er et offer for moras ansvarsløshet og selvopptatthet, mens den vesle nederlandske gutten blir et tilfeldig og uheldig offer for en gjerning som ikke er intendert eller planlagt med et slikt gruoppvekkende resultat. Det ene barnet er offer for ukontrollerbare og tilfeldige omstendigheter, mens det store barnet, Johnny, er et offer for en type omsorgssvikt og omkringliggende omstendigheter som medfører en stadig voksende destruktivitet og vilje til ondskap. Johnny planlegger sine handlinger nøye, observerer mennesker han ønsker å ramme, og viser en sann fryd over de ødeleggelsene han er i stand til å frambringe. Han sjekker lokalavisen for å se omtalene av det han har stelt i stand.

Johnnys ofre er mange. Ikke bare den vesle nederlandske gutten, men også guttens foreldre - som nærmest går i oppløsning når guttens mor må behandles i psykiatrien. For ekteparet Sundelin, som får sin babydatter stenket i dyreblod, fører handlingen til sist til at ekteskapet ikke fungerer, og de går fra hverandre. For ekteparet Landmark, der mannen lider av ALS (amyotrofisk lateral sklerose) og forventer en snarlig død etter fullstendig svekkelse av alle vitale funksjoner, fører hans handlinger med en tilsendt likvogn til forferdelse, men også til et lite glimt av humor i det hele. Begravelsesagenten som kommer med den bestilte likvognen, 
vekker mannens interesse som bilinteressert. De to blir enige om at når hans tid er omme, skal han føres til graven i et slikt fornemt kjøretøy! For den eldre kvinnen, Gunilla Mørk, som finner sin egen dødsannonse i lokalavisen mens hun drikker morgenkaffen, resulterer opplevelsen i angst og forskrekkelse, men også innbitthet. Hun vil finne ut hvem som står bak. For hundeeieren, Bjørn Schillinger, som erfarer at hans hunder har blitt sluppet ut i flokk og bitt i hjel et lite barn, blir skyldfølelse og vantro, men også sinne og hevntanker, resultatet. I sin bitterhet finner han sammen med Karsten Sundelin, og de to oppretter en form for vennskapsrelasjon. For ungjenta Else Meiner, som Johnny klipper det praktfulle håret $\mathrm{av}$, blir nok reaksjonen når Johnny blir funnet druknet ved den lokale dammen, en sorgreaksjon. Til tross for mobbing og trakassering er hun forelsket i ham.

\section{Det sårbare barnet}

Det er ikke hensikten her å gi et fullstendig resymé av plottet i de to romanene. Det som omhandles, er Fossums stadige tilbakevending til barnets rolle som sårbart individ. Barnet er utlevert til sine nærmeste, og barneårene er av største betydning for hvordan en voksentilværelse vil arte seg. Svikt og unnlatelsessynder i de avgjørende barneårene vil trolig alltid få konsekvenser, men det er likevel sjelden de får slike følger som for unggutten Johnny. Han har vokst opp til å bli et lite monster; en person som nyter å stelle til faenskap og tragedier. Han har nok aldri ment at påfunnene skal føre til annet enn forskrekkelse, men ett av dem får helt utilsiktede konsekvenser. Det er tilfeldig at lille Theo Bosch akkurat denne dagen går alene på skogstur, selv om det ikke er tilfeldig at hundeflokken slipper ut av hundegården. Det er faktisk den eneste tilfeldigheten denne romanen rommer, sett opp imot Johnnys kalkulerte, utspekulerte gjerninger. Han mente å ramme eieren av hundegården, men blir i stedet årsak til at den lille gutten mister livet. At Johnny selv blir funnet livløs i dammen, er romanens gåtefulle slutt. Ingen vet nøyaktig hva som har hendt. Er det de to vennene, Bjørn Schillinger og Karsten Sundelin, som har tatt saken i egne hender, eller er det en ren tilfeldighet at han har havnet i vannet? Ingen kan svare på dette. 
I romanen Den som frykter ulven er persongalleriet mer begrenset, og handlingen som fører til drap, mer preget av tilfeldigheter enn planlegging. Kannick - som ingen påakter, og som bare har den ansatte Margunn å trøste seg til - har et behov for oppmerksomhet som aldri blir tilfredsstilt. Han trener hardt for endelig å bli lagt merke til; det skal skje ved at han skal delta i bueskyttermesterskapet. Enn så lenge fordriver han tiden med å streife rundt med pil og bue i omgivelsene omkring institusjonen der han er plassert. Det er ulovlig å ta utstyret ut i skogen, men i Kannicks verden er slike forbud til for å brytes. Den tolvårige gutten kan nærmest karakteriseres som lystløgner, og driver hele tiden med unnaluring og omgåelse av regler. Han lyver om at han har sett Erkki Johrma, en forstyrret og underlig institusjonspasient, som streifer svartkledd og ordknapp rundt i området. Erkki beskyldes for mordet på Halldis Horn, og plottet kompliseres ved at Erkki tas som gissel av en bankraner og må dra til skogs sammen med sin overgriper. Linjene løper sammen idet de to tilbringer tid i et forfallent, forlatt hus i skogen der Kannick dukker opp med sine piler. Kannick rammer Erkki ved å skyte en pil i låret hans slik at han blør i hjel. På denne måten blir tolvårige Kannick dobbeltmorder.

Karin Fossums kriminalromaner handler alltid mer om årsakene til at noe skjer, enn om hvordan forbrytelsen utføres, samt hvem som er skyldig. Kriminelle handlinger er alltid et sosialt problem som berører samfunnet og rokker ved ro og likegyldighet. Den syttenårige Johnny er som enkeltindivid i stand til å destabilisere et helt lite lokalsamfunn. Han tenker på dette med en type ond fryd:

Han likte å sitte på mopeden, likte å være i fart og kjenne vinddraget i ansiktet. Mens han kjørte, så han for seg ansiktene til folk når de leste om hendelsen på Bjerketun. Han forestilte seg et omfattende register av skrekk og gru og harme. Rasende menn, fortørnede kvinner, illsinte gamlinger. Tanken fikk ham til å smile, der han for av sted på mopeden. Det var nesten så han ville klappe i hendene, men han fant det klokest å la dem bli liggende på styret. Folk skal ikke gå rundt og ta livet som en selvfølge, tenkte han, de skal ikke ta for gitt at alt det gode skal vare.

Døden kommer til alle.

Jeg skal faen meg vise dem. (Fossum, 2009, s. 42) 
Ondskapen som Johnny preges av i tanker og handlinger, kan både ses på som kompenseringsmekanismer for en tilværelse som taper og outsider og som resultat av traumatiske opplevelser i barndom og oppvekst. Moren nekter å fortelle ham hvem faren hans er, og til og med bestefaren føyser dette bort og ber ham om ikke å tenke på det. Johnny føler hevntrang og retter raseri og ondskap mot vilkårlige individer i nærmiljøet. Lars Fredrik Svendsen har hevdet at «[D]et onde er på den ene side noe abstrakt og uhåndterlig og på den annen side noe konkret og følbart» (Svendsen, 2013, s. 27), samt at ondskap er "gitt som et uomgjengelig aspekt ved verden» (sst.). Johnnys ondskap er både konkret og følbar, men mye av den uttrykkes mentalt når han fantaserer om hvordan han vil plage og ta livet av sin egen mor. For den unge Kannick er det snarere tale om en uidentifisert lengsel etter anerkjennelse og påaktelse enn om utstudert ondskap. Han beskylder den forstyrrede Erkki for mordet, men avsløres som dobbeltmorder. Det er trangen til å pynte på sannheten som til sist feller Kannick.

Som alltid i Karin Fossums thrillere er det etterforskerparet Konrad Sejer og Jacob Skarre som oppklarer forbrytelsene. De to arbeider systematisk og anvender metoder knyttet til psykologiske faktorer både hos ofre og hos potensielle overgriperne. Sejers samtaler med den tolvårige Kannick har preg av et onkel-nevø-forhold, slik at tillit oppstår. For Johnnys del er samtalene med Sejer, etter at han delvis legger «kortene på bordet», mange og lange. Johnny fastholder hele tiden at han aldri har lukket opp døra til hundegården - altså er han ikke skyldig i at lille Theo Bosch mister livet. Johnny har mistet det kjæreste han har, bestefaren, som spiser kjøttretten med rottegift som egentlig var beregnet på mora. Han har ikke lenger noe å tape, men har tydeligvis en sperre mot å medgi at han har vært direkte årsak til Theos død. Samvittigheten er svart, og da han blir funnet livløs i dammen etter å ha unnlatt å overholde meldeplikten på politistasjonen, blir dette en slags bekreftelse på at han bærer skyld for mer enn én persons død. Han beskylder sin egen mor for å ha forgiftet bestefaren - hun var ute etter pengene hans. Hans ønske om å ramme moren går i oppfyllelse, men ikke på det viset han planla. Hun fengsles og strever tungt med sine abstinenser $i$ arresten. 
De to romanene har det sårbare barnet som felles motiv, men som vist dreier det seg om barn i svært ulike aldre. For varsleren Johnny, som omkommer på grunn av sine handlinger, er traumatiske minner noe som daglig forfølger ham og som nærer fantasien om å drepe mora. For Kannick på Guttebakken er det uvisst hva som vil skje med ham. Helt til den siste samtalen med Sejer lyver han uavlatelig. Han avsløres, og idet dette skjer, aner leseren at han kommer til en form for erkjennelse: «Kannicks hjerte trakk seg voldsomt sammen og pumpet en flom av hett blod opp i ansiktet hans. Framtida var kommet» (Fossum, 1997, s. 252). For Kannick kan det finnes en framtid; for Johnny avsluttes et mislykket og traumatisk liv. Lars Svendsen hevder at «[S]elv om ethvert menneske under gitte omstendigheter ville ha vært i stand til å torturere et annet menneske, betyr det ikke at ethvert menneske ville ha gjort det» (Svendsen, 2013, s. 186). Gitte omstendigheter finnes for begge guttene: Kannick er blitt grundig forsømt og må kompensere, mens Johnny har utviklet en type ondskap og sluhet som gir ham en særegen fryd og glede. De er begge forsømte, skakkjørte, men også svært sårbare barn som tyr til vold og grusomheter både på impuls og som resultat av omhyggelig planlegging.

\section{Romantype}

Både Den som frykter ulven og Varsleren befinner seg i rekken av det som av anmelderne har blitt kategorisert som kriminallitteratur tilhørende undersjangeren politiromaner. Det som skiller de to romanene fra de øvrige i forfatterskapet, er vektleggingen av det sårbare barnet i rollen som overgriper og morder. Romanene kan også karakteriseres som en psykologisk thriller, slik den danske litteraturviteren Carsten Wind Meyhoff definerer sjangeren:

Den psykologiske thriller er en kraftfuld undergenre i udkanten af kriminallitteraturen og med en stor og tro læserskare, der er optaget af forbrydelser begået af mennesker med særlige psykologiske dispositioner. (Meyhoff, 2009, s. 210)

Meyhoffs utsagn om forbrytelser som begås av mennesker med spesielle psykologiske disposisjoner, viser seg treffende for handlingen $\mathrm{i}$ 
begge romanene. Det er tale om psykologiske disposisjoner forårsaket av manglende omsorg og faste rammer. Overordnet sett er romanene som de fleste av Fossums kriminalromaner: Konrad Sejer-romaner, der etterforskerparet Sejer og Skarre jakter på forbrytere og finner løsninger på kriminalgåtene. De plasserer seg i rekken av kriminalromaner med en spenningskurve der leseren presenteres for en begått eller potensiell forbrytelse - for så å følge en oppklaringsprosess mot en endelig løsning. Likevel er det mindre interessant å fokusere på whodunit (Skei, 2008) enn whydunit. Årsakene til en forbrytelse er følgelig av større interesse enn hvem som er forbryteren. Det er de bakenforliggende årsaksmekanismene som utløser en forbrytelse, som gir medrivende lesninger og ettertanker; ikke de groteske forbrytelsene per se.

I de fleste av Karin Fossums romaner finnes en underliggende følelse av empati med sårbare personer og et syn for urettferdigheten i samfunnet, noe som gjør at hennes forfatterskap kjennetegnes av psykologisk dybde og seriøsitet. På mange måter handler romanene hennes om de skjulte mekanismene i samfunnet som fører til kriminelle handlinger. Kriminalitet er alltid et sosialt problem, og av den grunn framstår representasjonen av den på flere måter som en avspeiling av samfunnet der den finner sted. De skandinaviske samfunnene har et juridisk system som fokuserer på forståelse og rehabilitering snarere enn hevn, og Karin Fossums romaner speiler karakteristika ved disse samfunnene. Med den danske litteraturforskeren Gunhild Agger kan vi si at «[D]et specielle fælles-nordiske varemærke er æstetisk blevet en særlig bekymring for velfærdssamfundets udvikling» (Agger, 2010, s. 20). Velferdssamfunnet bæres oppe ved at det juridiske systemet opprettholdes og respekteres. Det skaper forutsigbarhet og stabilitet. Av den grunn rokker ugjerninger og forbrytelser ved samfunnets basis og må etterforskes og straffes.

Spørsmålet om en presis sjangerdefinisjon kan by på problemer når vi diskuterer Karin Fossums romaner. Det er en kjensgjerning at forskere har karakterisert hennes kriminalromaner som thrillere så vel som politiromaner, og de har alle rett - fordi romanene inneholder elementer tilhørende begge sub-sjangrer. Andrew Nestingen hevder at

The thriller is a relevant example for us, for its pleasure is premised on unknown conspiracy and threat. The thriller does not require a particular semantics of 
crime or setting - the manor house of the classical detective story, the mean streets of the gangster film, the frontier of the Western or the castle of the gothic. The thriller's semantics of threat are insistently open: the threat can come from anywhere or anyone. When the state ceases to maintain systems for the mentally ill, the mentally ill are at large and can become the masters of plots of their own fashioning. (Nestingen, 2008, s. 34)

Nestingens synspunkter stemmer overens med refleksjoner over thrillersjangeren hos Carsten Wind Meyhoff, slik det er sitert tidligere i dette kapittelet. Selv om verken Kannick eller Johnny umiddelbart ville ha blitt diagnostisert som mentale avvikere, er det et faktum at begge bærer med seg traumer fra tidlig barndom som potensielt kan utløse grusomme handlinger; handlinger som ellers forbindes med galskap og mental ustabilitet.

\section{Stedets betydning for ugjerninger}

Karakteristisk for mange av Karin Fossums kriminalromaner er også valget av sted. Vi kan gjerne si at Drammen og omegn er den sentrale toposen i forfatterskapet, selv om byen aldri nevnes ved sitt rette navn. Like ofte som handlingen finner sted i selve byen, er det småstedene rundt som velges som åsteder. For de to omtalte romanene er det imidlertid en ytterligere forflytning ut i landskapet som blir sentral. Byen og tettstedene i nærheten er omgitt av skoger, og i de to romanene er det skoglandskapet som blir eksistensielt ladet og av avgjørende betydning for så vel protagonister som handlinger. Kannick i Den som frykter ulven streifer ustanselig omkring i skogen, og det er der han treffer på og tar livet av Erkki. Kannicks første drapsoffer, den eldre kvinnen Halldis Horn, bor også ensomt til i skogen - uten nære naboer. Johnny beveger seg omkring på mopeden i nærområdene, men det er likevel skogen som blir av betydning da lille Theo drepes av de løse hundene langt der inne. Grunnene til at skogen impliserer potensial for drap, død og forbrytelser, kan ses i sammenheng med betydningen av valgt topos eller topoi.

Den aristoteliske betydningen av ordet «topos» (flertall topoi) innebærer taksonomier av mulige talemåter eller minnesteder (sayables or 
commonplaces) (Rehg, 2009, s. 65), mens man i litteraturvitenskapen har gitt topos eller topoi en mer konkret betydning som for eksempel fiktive eller reelle steder. Ifølge Øivind Andersen har topos blitt en «betegnelse på konvensjonelle beskrivelser, f.eks. av et idyllisk landskap, storm på havet eller synet av en by i det fjerne» (Andersen, 1995, s. 160). For Fossums romaner er byen Drammen, og kanskje i særlig grad omegnen, en topos i tradisjonell, aristotelisk forstålse av begrepet. Det er her forfatteren Fossum henter ut sine ideer og skaper plott for romanene. Den «drammenske» eller østnorske toposen ser derfor ut til å konstituere et sted «hvor synspunktene eller poengene så å si ligger på lager», slik Andersen forklarer den vanligste betydningen av «topos» (Andersen, 1995, s. 154). Både byen og det omkringliggende landskapet med skog, vann og elver er gjenkjennelig og svært vanlig i en nordisk kontekst.

Den danske litteraturforskeren Anne Marit Waade har understreket betydningen av stedets spesielle realisme i skandinavisk kriminallitteratur og hevder at

Modsætningerne mellem det urbane og det rurale, provins og centrum, tra-
dition og modernitet er indbygget i en og samme fortælling, men stadigvæk
med et kritisk og skæbnesvangert blik på små steders fortræffelighed og med en
forestilling om, at ondskaben her blir mere fordækt. (Waade, 2010, s. 66)

Waades påpekning av at små steder rommer muligheter for å dekke over ondskap, viser seg treffende for begge de omtalte romanene. Johnny kjeder seg og finner lite mening i tilværelsen på tettstedet der han bor. Noe må hende, og det setter han selv i scene. Villastrøket der han bor, er todelt: noen nye, velutstyrte hus i kombinasjon med eldre, nedslitte. På overflaten er dette et sted der lite hender, men med Waade kan vi si at der kan ondskapen finnes i det skjulte. At tettstedet er lite og dermed oversiktlig, har også en betydning for plott og spenningskurve i romanen. Johnny har en sann glede av at folk kjenner hverandre og samtaler om det fryktelige som skjer i nabolaget. Det ville ha vært vanskeligere å få i stand i et større bysamfunn. Johnny har med andre ord en begrenset radius for sine onde gjerninger og bisarre påfunn. Tettstedet som ligger nært til byen, setter dermed rammer for forbrytelsene, og det skapes en konsentrasjon av frykt og destruktive krefter. 
For Kannick er det området omkring institusjonen som både byr på potensial for spenning og skjul for grufulle handlinger. Byen ligger på avstand, og det er nærmeste tettsted og skogen handlingen konsentreres til. Waade diskuterer en adaptasjon av nettopp Den som frykter ulven i artikkelen om skandinavisk kriminallitteratur der vektleggingen er på «små steder - store forbrytelser» (Waade, 2010). Hun understreker ikke bare betydningen av småsteder, men også av ikoniske landskaper, i dette tilfellet skogen. For Kannick konstituerer skogen omkring institusjonen et ikonisk sted. For ham inngir den både spenning og trygghet, mens skogen og skoglandskaper ellers har konnotasjoner til skrekkblandede erfaringer som å gå seg vill og ikke være i stand til å finne veien tilbake til utgangspunktet. Den truende, mørke og uhyggelige skogen finnes som tematikk i sagalitteraturen og middelalderlitteraturen, mens skogen i Fossums roman er en topos ladet med positivitet. I skogen realiserer Kannick seg selv og får ut det potensialet han innehar. For ham blir skogen derfor et sted for tilhørighet og identitetsbekreftelse, der han ser seg selv i rollen som landets beste bueskytter; en rolle som er fjernt fra virkeligheten på institusjonen - der han må skryte og dele ut godterier om han skal finne vennskap. Kannick drømmer om å bli lagt merke til, være maskulin og attraktiv; muligheter som institusjonstilværelsen ikke gir rom for (Massey, 1994).

For skandinavisk krimlitteratur er det ifølge Waade småstedene og omgivelsene som skaper realisme. Det beskjedne tettstedet og den omgivende skogen blir i romanene topoi som konnoterer både muligheter for personlig realisering og det motsatte: potensial for død og utslettelse. Johnny gjenfinnes drivende livløs i dammen i skogen, mens Kannicks ugjerninger begge er relatert til skoglandskaper. Halldis' hus ligger avsides uten naboer, og hytta der Kannick havner sammen med Erkki og hans gisseltaker, ligger ensomt til i skogen. Dette er steder eller topoi som normalt konnoterer stabilitet, tilhørighet og trygghet, men som i disse to romanene til sist får motsatt fortegn.

Det forblir et åpent spørsmål om stedene i de to romanene på avgjørende måter frambringer de gruoppvekkende hendelsene og forbrytelsene som blir begått av et barn og en ungdom. Sikkert er det imidlertid at det er relativt enkelt for en ungdom som Johnny å finne sine ofre innenfor en begrenset sirkel; et område han kjenner svært godt. For Kannick er det 
den omgivende skogen som gir ham muligheter til å streife omkring med pil og bue og få ham til å kjenne seg som en vinner. I realiteten er begge de to tapere: Johnny, som kjører venneløs og forsømt rundt på mopeden, og Kannick, som lever kjærlighetsløst i en overdimensjonert kropp. Felles for dem begge er at de forlater hjemmet, dvs. huset der Johnny bor med moren, og institusjonen der Kannick har tilhold, for å utføre sine handlinger. Det som skiller de to på et avgjørende punkt, er imidlertid intensjon og beregning. Mens Johnny bevisst og med fryd utfører sine udåder og listig planlegger neste trekk, er Kannicks handlinger resultat av impulsivitet og panikk. Johnnys planlagte udåder er ment å forskrekke og uroe, mens Kannicks ugjerninger blir utløst av redsel og overrumpling. Johnny er slu og beregnende, mens Kannick er klosset og uheldig i sine disposisjoner. Like fullt blir resultatet av begges gjerninger at mennesker mister livet.

Det sårbare barnet blir i begge to romanene gitt dårlige betingelser for å lykkes i livet. Det store barnet, Johnny, lever sitt liv uten foreldreomsorg. Bare bestefaren kan fylle noe av behovet for stabilitet og kjærlighet. I stedet for fortrolighet og trygghet byr moren ham neglisjering, alkoholmisbruk og apati. Kannicks mor ligger ikke under for slike laster, men viser ingen omsorgsevne og interesse for sitt barn. Han blir kun en klamp om foten. I avgjørende oppvekstår blir de to fratatt trygge rammer, kjærlig omsorg og hengivenhet. Da må dette kompenseres, og for begge guttene fører de kompensatoriske handlingsmønstrene til katastrofer for mennesker i deres umiddelbar nærhet - uerstattelige tap og ødelagte liv.

Spørsmålet om gjerningene er utslag av ondskap, kan også reises, selv om det som skjer i disse romanene, er forårsaket av barn. For Fossums to romaner med barn som overgripere og drapsmenn blir ondskapen både konkret og svært følbar, men like fullt må leseren reflektere over graden av ondskap, om ondskap egentlig er rett betegnelse, og om de to protagonistene med mer omsorg og omtanke kunne ha endt opp som vellykkede og lykkelige individer.

\section{Døden som resultat av uheldige omstendigheter}

Døden kommer i Kannicks og Johnnys tilfelle både som resultat av en ren panikkhandling og som resultat av en tilfeldighet. Det er panikk som slår 
Kannick da Halldis Horn griper ham på fersk gjerning idet han er i ferd med å stjele lommeboken hennes fra brødboksen i huset. Han griper til hakken som den eldre kvinnen har brukt i hagen rundt huset, og støter den dypt i øyet hennes. Døden kommer brått og uventet. Det samme kan fastslås om Erkkis død i skogen, da Kannick skyter en pil i låret hans. Døden kommer også der brått og høyst uventet, selv om dramatikken rundt gisselsituasjonen har utspilt seg på forhånd.

For Johnnys offer, den vesle nederlandske gutten Theo, er det rene tilfeldigheter som gjør at han akkurat denne dagen går alene i skogen. Hundene river gutten i filler, og døden kommer som sjokk og gru. Theos mor går nærmest til grunne, og må hjelpes i psykiatrien da hun får greie på hva som er hendt med sønnen. Johnnys bestefar dør som følge av at Johnny har hatt rottegift oppi en gryterett. Den var imidlertid ment for Johnnys mor, og dette dødsfallet frarøver Johnny den eneste omsorgspersonen i hans nære krets. Johnnys øvrige ugjerninger medfører ikke direkte død, men snarere oppløsning og ulykke. Det er ingen ting i veien med den lille babyen som blir stenket i blod. Hun er frisk, men foreldrenes ekteskap går i oppløsning da de ikke greier å kommunisere tilstrekkelig om hendelsen. For de øvrige ofrene for Johnnys påfunn er det tale om forskrekkelse, forbannelse og oppgitthet, men ingen livstruende hendelser. Da Johnny blir funnet druknet i den lokale dammen, er det uvisst om drukningen er forårsaket av at noen har dyttet ham uti, eller om han selv har valgt døden. Han har uansett ingen lyse framtidsutsikter; moren er fengslet, og bestefaren er død. Døden blir et endelig og nærmest naturlig punktum. For Kannick kan døden han har forårsaket for to mennesker, snarere innebære en begynnelse. Selv om boken ikke antyder hva som vil hende med ham, er han for ung til å straffes, og han vil trolig bli gjenstand for spesialtiltak og dermed omsorg i det psykososiale hjelpeapparatet. At det er håp for Kannick, antydes mot romanens slutt, da det blir klart at det er Kannick som har drept Erkki og Halldis Horn. Da beskrives hans reaksjon som en form for erkjennelse. Framtida for Kannick kan innebære at han både må og vil ønske å ta ansvar for egne gjerninger. For en tolvårig gutt finnes det dermed en fortsettelse, men for tenåringen Johnny kommer drukningsdøden som en endelig slutt på alle hans problemer og hans miserable tilværelse. 
Karin Fossums kriminalromaner skiller seg fra majoriteten av slike bøker ved at barn inngår i rollen som overgripere og mordere. Likevel er barna skildret med empati og forståelse, slik at leseren sitter igjen med forklaringer på hendelser og sammenhenger som er både plausible og naturlige. Barndom og oppvekst er av avgjørende betydning for hvordan voksentilværelsen vil arte seg. Omsorgssvikt og neglisjering blir derfor katastrofalt for et barn, noe disse to romanene viser med all tydelighet.

\section{Referanser}

Agger, Gunhild (1999). Intertextuality Revisited: Dialogues and Negotiations in Media Studies, Canadian Aesthetics Journal / Revue canadienne d'esthétique, 4. Agger, Gunhild (2010). Krimi med social samvittighed. Skandinavisk krimifiktion, medialisering og kulturelt medborgerskab. I Gunhild Agger \& Anne Marit Waade (Red.), Den skandinaviske krimi. Bestseller og blockbuster. Göteborg: Nordicom.

Allen, Graham (2000). Intertextuality. London: Routledge.

Andersen, Øivind (1995). I retorikkens hage. Oslo: Universitetsforlaget.

Cunningham, Hugh (2006). The Invention of Childhood. London: BBC Books.

Fossum, Karin (1997). Den som frykter ulven. Oslo: J.W. Cappelens Forlag AS.

Fossum, Karin (2009). Varsleren. Oslo: Cappelen Damm AS.

Langås, Unni (2015). Traumets betydning i norsk samtidslitteratur. Bergen: Fagbokforlaget.

Massey, Doreen (1994). Space, Place and Gender. Cambridge: Polity Press.

Meyhoff, Karsten Wind (2009). Forbrydelsens elementer. Kriminallitteraturens historie fra Poe til Ellroy. København: Informations Forlag.

Nestingen, Andrew (2008). Crime and Fantasy in Scandinavia. Fiction, Film, and Social Change. Seattle: University of Washington Press.

Rehg, William (2009). Cogent Science in Context. The Science Wars, Argumentation Theory, and Habermas. Cambridge, MA/London: The MIT Press.

Skei, Hans H. (2008). Blodig alvor. Om kriminallitteraturen. Oslo: Aschehoug. Svendsen, Lars Fr. H. (2013 [2001]). Ondskapens filosofi. Oslo: Universitetsforlaget. Waade, Anne Marit (2010). Små steder - store forbrydelser. Stedspecifik realisme, provinsmiljø og rurale landskaber i skandinaviske krimiserier. I Gunhild Agger \& Anne Marit Waade (Red.), Den skandinaviske krimi. Bestseller og blockbuster. Göteborg: Nordicom. 



\title{
Barnedrapenes stereotype medielogikk
}

\section{Avisers førsteoppslag når barn dør etter vold og omsorgssvikt i familien}

\section{Jorun Ulvestad}

\section{Universitetet i Sørøst-Norge}

\begin{abstract}
Summary: This article presents a number of first reports, in which news about children who died due to violence and child neglect, are covered in two Norwegian national newspapers from 2010 to 2017. The study is based on a social constructionist perspective. Through multimodal analysis we examine the practices of the newspapers regarding which main sources the journalists use, and how these choices establish a framework for the understanding. In contexts where the police are the preferred main source, the death of the children emerges as crime narratives. This forms a main pattern that might be featured as «the stereotype first report logic of infanticide». When it comes to first reports based on representatives of the judicial system as the main source, this logic is recycled with this system in the leading role. As a consequence, the journalist's professional role is narrowed, while the power and influence of the police and justice system, however, are consolidated. From time to time variations in this main pattern occur, and these variations contribute to forming the discourse in line with a civic and interpersonal rationale.
\end{abstract}

Keywords: crime narratives, discourse, newspapers, infanticide, power

«Tiltalt for å ha ristet babyen sin til døde:

Jeg var en god far» (Overskrift i VG 05.12.2016)

\section{Introduksjon}

Mange norske avislesere kjenner til historien om åtte år gamle Christoffer Kihle Gjerstad, gutten som i 2005 ble funnet død i sin egen seng som følge av langvarig mishandling av sin stefar. Saken fikk stor oppmerksomhet i media, og Christoffer har i ettertid blitt beskrevet som «et nasjonalt symbol

Sitering av denne artikkelen: Ulvestad, J., (2018). Barnedrapenes stereotype medielogikk. Avisers førsteoppslag når barn dør etter vold og omsorgssvikt i familien. I A. Johannessen, N. Askeland, I. B. Jørgensen \& J. Ulvestad (Red.), Døden i livet (Kap. 12, s. 207-228). Oslo: Cappelen Damm Akademisk. https://doi. org/10.23865/noasp.40.ch12

Lisens: CC BY-NC 4.0 
på systemsvikt og vold mot barn» (Jensen \& Berglund, 2013 s. 3) ${ }^{1}$. Medieoppslagene handlet om hvordan et forsvarsløst barn over tid kunne bli utsatt for massiv vold uten at noen grep inn, om hvem som lukket øynene for guttens lidelser, og om hvordan skolen sviktet sin rapporteringsplikt (Gangdal, 2011).

Ikke alle saker om barn som dør som følge av vold eller omsorgssvikt i hjemmet, får like stor oppmerksomhet. Noen blir ikke nevnt, uten at det trenger å være åpenbare grunner til det $(S t a v, 2016)^{2}$. Mange saker slås imidlertid opp som selvstendige nyhetssaker, gjerne når barnet dør plutselig og på dramatisk vis. Slik har avislesere de seneste årene fått innsikt i flere historier; blant annet om en halvannet år gammel jente som døde i 2010 etter at moren hadde mishandlet og druknet henne i en bøtte (VG 10.11.2011, Aftenposten 20.10.2013), en ti uker gammel gutt som i 2014 ble filleristet av sin far og deretter døde av skadene (VG 05.12.2016, Aftenposten 04.12.2016), og en 17 år gammel gutt som i 2014 ble drept av sin far med øks, der faren i etterkant tok sitt eget liv (VG 31.02.2014, Aftenposten 31.12.2014).

Gjennom arbeidet med denne studien har det vist seg at tidspunktene for avisenes førsteoppslag varierer. Noen ganger kommer de kort tid etter at politiet har fått melding fra lege, sykehus eller barnevern om et barn som er alvorlig skadet eller omkommet, og hvor det er mistanke om vold eller alvorlig omsorgssvikt i familien. Andre ganger blir begivenhetene omtalt for første gang lenge etter dødsfallet, kanskje først når saken skal behandles i rettsapparatet. Uansett slås gjerne stoffet opp som kriminalsaker - noe de ofte også er. Men de er ikke bare det: Dødsfall som involverer barn, er sosiale hendelser med mange aspekter, ofte med en lang forhistorie der enkeltpersoner og institusjoner er involvert på forskjellige måter og har ulike typer ansvar for barna. Spørsmålet er på hvilken måte avisene ivaretar denne kompleksiteten.

I dette kapittelet tar jeg utgangspunkt i de sakene som har blitt omtalt i to store norske aviser - Verdens Gang (VG) og Aftenposten - gjennom

http://docplayer.me/6955055-Meldeplikt-til-barnevernet-mot-til-a-se-trygghet-til-a-handle.html https://www.aftenposten.no/meninger/debatt/i/l397/De-som-mishandler-barn-til-dode-garsom-oftest-fri--Jannicke-Stav 
en periode på drøye syv år. Jeg undersøker hvordan disse fremstiller barna, foreldrene og det samfunnet de inngår i, når sakene slås opp første gang. Jeg er opptatt av hvilke aktører som slipper til, hva oppslagene tematiserer på hvilke måter, samt hvilke aktører og fremstillinger som eventuelt er fraværende. Hensikten er å forstå mer av hvordan barns død som følge av vold og omsorgssvikt blir forstått og presentert - og hvilke virkelighetsbilder som dermed får forrang. Gjennom det som kommer til syne når det selvfølgelige gjøres eksplisitt, kan vi komme på sporet av hvilke valg som tas. Avslutningsvis ser jeg nærmere på hvilken betydning nettopp slike valg kan få.

\section{Den innledende versjonen står sterkt}

Da jeg på 1980-tallet arbeidet som fylkeskommunal prosjektleder for landets første ordning med beredskapshjem, ble jeg kjent med en rekke barn som hadde vært utsatt for vold og omsorgssvikt. Historiene deres var ikke alltid enkle å forstå, blant annet fordi det eksisterte mange ulike perspektiver og versjoner både fra barna selv, foreldrene, skole, barnehage, politi og helsevesen. Jeg var spesielt opptatt av hvordan barnas samlede historie og de hendelsene som førte til omsorgsovertakelsen, til syvende og sist ble tolket og presentert i hjelpeapparatets arbeid. Det var særlig ett forhold som uroet meg: Jeg reagerte på hvordan den komplekse historien fant sin form på et tidlig tidspunkt, og at den ikke i særlig grad forandret seg. Det skulle mye til for at de første forståelsene ble endret, til tross for at nye perspektiver ble spilt inn. For meg ble dette en indikasjon på at innledende versjoner raskt kan få status som sannhet, uten at kompleksiteten nødvendigvis kommer til syne.

Hva så med de innledende versjonene i media? Sannhet står sentralt i journalistikken og tillegges stor verdi. Nyheter skal avspeile virkeligheten, være objektive og informere allmennheten om viktige hendelser. Ideelt sett skal de også gå i dybden og være kritisk granskende (Haslebo \& Haslebo, 2010). I Veer Varsom-plakaten ${ }^{3}$ fremheves det i pkt. 4.3 at journalister skal vise respekt for menneskers egenart og identitet, privatliv, 
etnisitet, nasjonalitet og livssyn, noe som innebærer at dekning av sterke hendelser kan medføre presseetiske problemer når det gjelder personvern. Redaktørplakaten ${ }^{4}$ understreker redaktørenes uavhengighet, plikter og ansvar. Å bidra til å oppfylle samtlige av disse kravene kan tidvis være problematisk. Blant annet er tilgangen til kilder som kan sikre at virkeligheten blir beskrevet på en sann og objektiv måte, en utfordring. Det gjelder ikke minst i lys av tidspresset som media arbeider under, og det stadig økende kravet til inntjening - samtidig som etikken skal ivaretas.

Spørsmålet om sannhet og objektivitet blir imidlertid ikke forstått på samme måte av alle. I dette kapittelet legger jeg til grunn et sosialkonstruksjonistisk perspektiv. Dette erkjennelsesteoretiske ståstedet innebærer en anerkjennelse av at det eksisterer mange ulike og parallelle virkeligheter. Hvilken virkelighet som skal gjelde, er imidlertid ikke gitt på forhånd. Den amerikanske psykologen Kenneth J. Gergen (2015) understreker at det vi til daglig oppfatter som sikker viten om virkeligheten, utvikles gjennom språklig interaksjon mennesker imellom. Den er dermed en sosialt forhandlet forståelse, basert på de relasjonene og de praksisene vi inngår $\mathrm{i}$, innenfor et kulturelt fellesskap.

Et slikt perspektiv innebærer en forståelse av at journalister ikke bare dekker en allerede eksisterende virkelighet som «finnes der ute», men at de selv er med på å skape virkeligheten (Haslebo \& Haslebo, 2010). Journalistenes valg mellom ulike versjoner er dermed med på å bestemme hva som blir til sanne og objektive nyheter, hvordan virkeligheten presenteres, og i neste omgang hvilke forståelser som etableres hos leserne - selv om det må innrømmes at det sjelden eksisterer noe én-til-én-forhold mellom fremstillingen og publikums forståelse (Fiske, 1996).

\section{Tallenes tale og forskning på feltet}

Det finnes ikke noe klart svar på hvor mange barn som faktisk dør som følge av foreldres vold eller omsorgssvikt i Norge. Grunnen er at det ikke eksisterer noen offisiell og fullstendig statistikk på feltet. Men gjennom de få studiene som er gjennomført, kan vi danne oss et visst bilde.

4 http://presse.no/pfu/etiske-regler/ 
Vibeke Ottesen (2016) fant i sitt doktorgradsarbeid at i løpet av en tjueårsperiode (1990-2009) ble 48 barn under tjue år drept av til sammen 39 foreldre eller steforeldre i Norge. I tillegg fremhever hun stor sannsynlighet for mørketall. VG Nett (03.05.2010) har gjort en gjennomgang av hvor mange barn som ble drept av sine foreldre i Norge i en tiårsperiode fra 2000 til 20105. Tallene fremkom gjennom et større kartleggingsarbeid med utgangspunkt i rettskraftige dommer, tallmateriale fra politiet og drapsstatistikk fra Kripos. Det viste seg at 27 barn ble drept av sine foreldre i denne perioden, mens seks barn ble så alvorlig mishandlet at de døde av skadene.

Forskning på omstendigheter som kan føre til slike drap, har ikke vært omfattende i Norge. En eldre undersøkelse peker på alvorlig sinnslidelse som forklaring på hvorfor mødre dreper (Grünfeld \& Steen, 1984), mens nyere forskning viser at foreldre av begge kjønn er involvert, og at disse hendelsene kan settes i sammenheng med samlivsbrudd og barnefordeling (Ottesen, 2016). I en undersøkelse fra USA konkluderer Cheryl L. Meyer og Michelle Oberman (2001) med at kvinnene som regel hverken er onde eller gale, men at deres livsbetingelser og de sosiale problemene de står overfor, bringer dem over kanten. Park Elliot Dietz (1986) var tidlig ute med å omtale family annihilators - menn som med vilje dreper sine barn. Studien viser at dette vanligvis er den eldste mannen i familien, og at han er deprimert, paranoid, påvirket av rusmidler eller en kombinasjon av dette - og gjerne begår selvdrap etter å ha drept de andre i familien, eller tvinger politiet til å drepe ham. Kate Cavanagh og kollegaer (2005) undersøkte gjerningsmennenes bakgrunn, og fremhever faktorer som lave sosioøkonomiske kår, liten utdanning samt arbeidsledighet.

Når det gjelder forskning som er innrettet mot systemnivået i vårt eget land, handler den i første rekke om å identifisere skyld og forsømmelse på tjenestenivå når barn dør, uansett årsak (Backe-Hansen, Smette \& Vislie, 2017). Disse arbeidene favner med andre ord langt bredere enn dette kapittelets tematikk. Verd å merke seg er imidlertid at forskning på barnedød i et internasjonalt perspektiv viser at relativ fattigdom har stor betydning for barnehelse generelt, og angis som den viktigste

5 https://www.vg.no/nyheter/innenriks/barnemishandling/33-barn-drept-og-doedelig-mishandletav-sine-foreldre/a/10004899/ 
bakenforliggende faktoren når det gjelder barnedødsfall i høyinntektsland (Sidebotham mfl., 2014).

Forskning på medias dekning av barnedrap i familien har vært sparsom. I en norsk kontekst har Soilikki Vettenranta (2005) berørt tematikken når hun tar for seg ungdoms reaksjoner på katastrofenyheter i ulike medier. Her viser hun hvordan journalistenes valg av fremstilling gjennom tekst og bilde har betydning for hvordan de unge opplever og lar seg berøre av hendelsene. Heller ikke internasjonalt har det vært akademisk interesse for medias dekning av barnedrap i familien, utover studier rettet inn mot avisenes dekning av barnemishandling generelt (Hove, Paek, Isaacson \& Cole, 2013). Medieforskningen har med andre ord i liten grad interessert seg for hvordan avisene tar i bruk mulighetene til å skape nyheter på dette feltet på en slik måte at publikums forståelsesrammer utfordres og utvikles.

\section{Utvalg og analysestrategi}

I denne studien undersøker jeg alle eksisterende førsteoppslag i to norske aviser om barns død relatert til vold og omsorgssvikt i hjemmet som er publisert de siste 7,5 årene - fra 1. januar 2010 til 1. juli 2017. Når valget falt på henholdsvis Aftenposten og VG, var dette fordi de begge er sentrale riksaviser, men også forskjellige: Aftenposten er landets største abonnementsavis, mens VG er en løssalgsavis som samtidig er størst på nett. Til sammen henvender de seg til et stort publikum, og har derfor potensielt stor informasjons- og påvirkningskraft.

Samlet har jeg identifisert 16 ulike saker. De har alle vært slått opp i begge disse avisenes nettutgaver, der nettutgavene også dekker papirutgavene. Sakene omhandler til sammen 18 barn som døde etter det som i utgangspunktet ble forstått som vold eller omsorgssvikt fra én eller begge foreldrene. Foreldre betegner i denne sammenhengen både biologiske og sosiale foreldre, samt nåværende eller tidligere steforeldre. Barnas alder $\mathrm{i}$ disse sakene er fra o til 18 år.

Det viste seg vanskelig å spore alle de aktuelle oppslagene gjennom søk i mediearkivet A-tekst, fordi mange saker ikke lot seg identifisere gjennom felles søkeord. Jeg valgte derfor å bruke søkemotoren Google i 
arbeidet med å identifisere de ulike oppslagene, og startet med de sakene jeg hadde oversikt over som alminnelig oppmerksom avisleser. Derfra gikk jeg videre til andre saker som det fra tid til annen ble henvist til i teksten. I tillegg brukte jeg søkeord som «barnedrap», «mor siktet», «far siktet», «gutt døde», «jente døde», «baby døde» og andre begreper jeg etter hvert definerte som sentrale. Ut over dette slo jeg opp alle lenkene som var lagt inn i avisoppslagene, og sporet dessuten via journalistenes navn. Gjennom disse ulike innfallsvinklene fikk jeg etter hvert oversikt over 32 førsteoppslag, likt fordelt på de to avisene. Disse danner utgangspunktet for denne studien av avisenes innledende versjoner om barnedrap.

\section{Diskursanalyse som både språklig og materielt felt}

Diskursanalyser bygger i stor grad på en strukturalistisk og poststrukturalistisk språkfilosofi som hevder at tilgangen til det virkelige alltid går gjennom språket. Ifølge Iver B. Neumann (2001) skjedde det på 1960-tallet en endring i forståelsen av diskurser: Fra diskurs som grunnlag for lingvistisk orientert tekstanalyse til en mer samfunnsvitenskapelig forståelse av diskurs. Denne siste la vekt på diskursen som et samfunnsfenomen gjennom en sammensmelting av tekst og materialitet - slik dette kapittelet tar høyde for.

Den franske sosialfilosofen Michel Foucault (1972) definerer diskurser som praksiser som systematisk former de objektene som de tilsynelatende omtaler eller dreier seg om. Gjennom denne omtalen får de sin eksistens. En slik refleksiv kunnskapsproduksjon foregår innenfor gitte institusjonelle rammer som setter grenser for hva som kan ses og sies innenfor et bestemt felt. Diskursen er med andre ord en slags regulering av hvem som kan snakke når, om hva, på hvilken måte - og hva denne samtalen trekker på. Gjennom å studere konkrete diskurser, deres forutsetninger og betingelser vil vi kunne forstå mer av det sosiale og det politiske.

Diskursanalyse er et vidt felt, og innenfor dette blir diskursbegrepet anvendt på flere måter. En kritisk diskursanalyse, slik begrepet anvendes her, ser det som sin oppgave å vise hvordan språket og de rådende 
logikkene kan bidra til å opprettholde en sosial verden og sosiale roller på måter som kan bidra til asymmetriske maktforhold. Den forsøker å vise hvordan språklige representasjoner er historisk og kulturelt betinget og således foranderlige, og at det finnes muligheter for å handle og tenke på andre måter enn de eksisterende (Eide, 2001; Neumann, 2001; Ulvestad, 2010).

En diskursanalyse som plasserer seg innenfor en sosialkonstruksjonistisk tradisjon, tar som nevnt høyde for at tolkning og forklaring både er et subjektivt og et kulturelt anliggende (Gergen, 2015). Dette gjelder også for meg - som forsker. Lesningene jeg gjennomfører av det utvalgte materialet, kan i et slikt perspektiv potensielt beskrives og forklares på mange andre måter enn slik jeg gjør det. Den foreliggende analysen har derfor først og fremst verdi gjennom de innsiktene som kan oppnås gjennom mine konstruksjoner, når disse fungerer som pålitelige og troverdige for leseren. En slik posisjonering innebærer å forlate den moderne troen på kunnskap som en avspeiling av virkeligheten, til fordel for en forståelse av kunnskapsgrunnlagets relative troverdighet (Polkinghorn, 1983).

\section{Hovedmønster med ulike variasjoner}

Når avisene slår opp en nyhetssak, handler det om å presentere det aller viktigste i kortversjon så tidlig som mulig (Bang, 2003). Den vanlige formen for nyheter tar dermed utgangspunkt i den omvendte pyramide, en metafor som beskriver en opprinnelig amerikansk tradisjon: Det aller viktigste plasseres først, eller øverst - i overskriften. Deretter følger ingressen, som også er helt sentral. Etter hvert kommer de mer perifere momentene, bakgrunnen og sammenhengen (Gripsrud, 2015). Dermed kan artikkelen enklere kuttes nedenfra, ved behov. Journalister og nyhetsredaktører flest vil kjenne igjen og arbeide etter disse hovedprinsippene (Bang, 2003).

I et slikt perspektiv kan overskrifter i avisene beskrives som journalistikkens mest iøynefallende og betydningsfulle tekstelementer. I tillegg til å skape oppmerksomhet og pirre nysgjerrigheten har overskriften en resepsjonsstyrende funksjon - det vil si at den styrer leserens oppfatning av den påfølgende teksten, og er dermed et særdeles viktig tekststrategisk 
felt (Frandsen, 1991). Dette siste gjelder også ingressen, som er plassert mellom overskriften og brødteksten. Både overskrift og ingress settes gjerne av desken (Hågvar, 2007), og i samspill med journalistens tekst utgjør disse en enhet som bidrar til å legge de første premissene for lesernes forståelse av saken.

Også bildene bidrar til lesernes forståelse. De er effektive oppmerksomhetsvekkere, og fungerer som kontekst for teksten. Den franske sosiologen og semiologen Roland Barthes (1999) understreker av den grunn at bilder er retoriske og ikke uskyldige. De er ladet med meninger og føringer både på det denotative og det konnotative nivået, der det første handler om hvilke virkemidler som tas i bruk, mens det siste handler om bildets betydning.

I det følgende tar jeg for meg både overskrifter, ingresser og bilder hentet fra de to avisenes førsteoppslag, gjennom en multimodal analyse (Veum, 2008). Jeg innleder med å presentere én av sakene i det totale materialet. Her fremstår begge førsteoppslagene, både i form og innhold, som typiske og gjenkjennelige - det jeg senere vil omtale som et hovedmønster. Deretter følger jeg opp med ytterligere førsteoppslag som steg for steg viser variasjoner over denne grunnmodellen. Artikkelens format begrenser antallet konkrete analyser. Resultater fra analysen av førsteoppslag som ikke blir konkret presentert, trekker jeg inn i den avsluttende drøftingen.

\section{Politiets stemme - en autoritet på feltet}

Den første saken fremstår i VG som en klassisk kriminalsak. Politiets opplysninger legges til grunn i overskriften, og politiet nevnes også direkte i ingressen. Som vi ser, er det politifaglige forhold som siktelse og varetektsfengsling som dominerer. Politiets stemme er tydelig og direkte til stede.

Foreldrepar siktet etter at treåring døde ${ }^{* *}$ Faren varetektsfengslet (overskrift VG 11.03.2014)

Foreldrene til en gutt (3) er siktet for legemsbeskadigelse med døden til følge etter at han døde $i$ Rana $i$ Nordland forrige helg, opplyser politiet (ingress VG 11.03.2014) 
Som vi forstår, har det skjedd en forbrytelse der offeret er et lite barn på tre år; saken blir etterforsket av politiet, og foreldrene er siktet. Bildet ${ }^{6}$ som følger saken, understreker politiets posisjon. På det denotative nivået kan dette forklares som nærbilde av et stort hus, med skiltet POLITI tydelig og synlig over inngangspartiet. Bildet konnoterer sammen med overskrift og ingress at her er det politiet, som en etablert og tung samfunnsinstitusjon med betydelig makt og autoritet, som har hånd om saken. Slik blir synspunktene til denne autoriteten i samfunnet legitimert og stadfestet. De menneskene som blir omtalt i oppslaget, gis derimot ingen stemme. I et narrativt perspektiv (Gripsrud, 2015) innebærer fremstillingen at politiet får tildelt rollen som helt, hovedperson eller protagonist. Skurken i fortellingen - antagonisten, er foreldrene, her med faren i fokus.

Aftenpostens oppslag av den samme saken er ikke illustrert med noe bilde. Vi ser imidlertid at overskrift og ingress følger samme mønster som i VG, med politiet som protagonist og foreldrene som antagonister - i første rekke faren.

Foreldrepar siktet etter at treåring døde (overskrift Aftenposten 11.03.2014)

Politiet $i$ Nordland har siktet foreldrene til en tre år gammel gutt etter at sykehuset slo alarm om guttens dødsfall. Faren varetektsfengslet mandag (ingress Aftenposten 11.03.2014)

Begge avisene presenterer saken ni dager etter dødsfallet, og politiet fungerer som hovedkilde. Det er deres etterforskning av den kriminelle handlingen og de antatte gjerningspersonene som plasseres i fokus. Politiet bidrar dermed til å ramme inn, legitimere og posisjonere saken, som formidles gjennom deres perspektiv og begrepsbruk. Gjennom språket løftes de politifaglige oppgavene som siktelse og fengsling frem, i tråd med et politifaglig rasjonale.

\section{Samfunnsansvaret løftes frem}

Den neste saken jeg trekker frem, viser hvordan de to ulike avisenes førsteoppslag om samme sak fremtrer svært ulikt. VG presenterer, samme

6 https://www.vg.no/nyheter/innenriks/foreldrepar-siktet-etter-at-treaaring-doede/a/10146136/ 
dag som hendelsen skjer, et førsteoppslag som følger det samme mønsteret som i forrige sak, med politiet som hovedkilde og protagonist, der saken fremstår som en kriminalsak med en av foreldrene som antagonist.

Gutt (1) funnet død - faren (29) pågrepet (overskrift VG 27.11.2013)

VANVIKAN/OSLO (VG) Politiet mener den lille gutten (1) døde under mystiske omstendigheter i Leksvik $i$ Nord-Trøndelag (ingress VG 27.11.2013)

Hendelsen omtales i et politifaglig språk, og uttrykker et politifaglig rasjonale der guttens $d ø d$ følges opp med faren som er pågrepet. Det første av de to bildene ${ }^{7}$ som følger saken, viser en politimann i full uniform bak et skrivebord. Det er utstyrt med en videoknapp til VG Nett, der den samme politimannen orienterer om politiets arbeid. Bilde nummer to viser en politimann i full uniform, fotografert bakfra. Til sammen konnoterer oppslaget en statsmakt som er til stede og tar ansvar.

Aftenpostens førsteoppslag om samme sak danner imidlertid en interessant kontrast når dette kommer, først et drøyt år etter VGs førsteoppslag. Da har politiet gjort seg ferdig med etterforskningen, og saken er overført til påtalemakten.

Gutt (1) ble funnet død - saken henlagt, ingen i hjelpeapparatet straffes (overskrift Aftenposten 01.12.2014)

Den 15 måneder gamle gutten ble funnet død i hjemmet sitt. Mange etater visste han var utsatt, men ingen klarte å forhindre dødsfallet (ingress Aftenposten $01.12 .2014)$

Som overskriften viser, har statsadvokaten valgt å henlegge saken. I kombinasjonen mellom overskrift og ingress får vi forståelsen av at en rekke samfunnsinstitusjoner har vært gransket som mulige (med)ansvarlige for guttens død, uten at noen av disse er blitt dømt. Det følger ingen bilder med saken. Som overskrift og ingress indikerer, er oppslaget som helhet en journalistisk bredt anlagt reportasje, der mange elementer får plass og kompleksiteten synliggjøres - uten at det refereres til politiet eller rettsapparatet som kilde. 
Et viktig poeng som tydeliggjøres gjennom dette oppslaget, er at også samfunnsinstitusjoner kan stilles til ansvar når barn dør i hjemmet. Innenfor denne diskursen om barnedrap i privatsfæren kan med andre ord posisjonen som antagonist bekles både av foreldre og av hjelpeapparatet, der de siste også inngår i et strukturelt anlagt perspektiv. Dermed ser vi demonstrert hvordan overskrift og ingress i en relativt bred journalistisk reportasje, med bruk av flere kilder, åpner opp for nye blikk og inviterer til innsikt som går ut over en tradisjonell fokusering på individet.

\section{Kriminalfortelling rammet inn av situasjonskonteksten}

I den tredje saken jeg løfter frem, er vi tilbake i mønsteret der individet innenfor privatsfæren står i fokus som potensiell antagonist, i begge avisene. Saken dekkes tre dager etter dødsfallet både i VG og Aftenposten. VG gjengir siktelsen i overskriften, og understreker dermed at dette er en kriminalsak.

Mor siktet etter at 13-åring døde. ${ }^{* *}$ Mor varslet nødetatene ${ }^{* *}$ Forsøkt avhørt lørdag (overskrift VG 03.01.2016)

En mor er siktet for grov omsorgssvikt med døden til følge etter at en 13 år gammel jente døde i Valdres på nyttårsaften (ingress VG 03.01.2016)

Bildet $^{8}$ i VG er et stort nærbilde av en politikvinne i full uniform, som intervjues med politistasjonen i bakgrunnen. Motivet konnoterer autoritet og statsmakt; her møtes en kriminalsak med lov og orden. Bildet har en videoknapp til VG TV, der vi kan følge en journalist som intervjuer politikvinnen om politiets arbeid og utviklingen i saken. Til sammen utgjør tekst og bilde en tydelig markering av at det er politiet som har hånd om saken.

Også Aftenpostens førsteoppslag tar utgangspunkt i politiets perspektiv på hendelsen; som en kriminalsak, der politiet posisjoneres som protagonist.

8 https://www.vg.no/nyheter/innenriks/krim/mor-siktet-etter-at-13-aaring-doede/a/2358936o/ 
Mor er siktet etter at datteren (13) døde på hytte $i$ Valdres - tidligere skolekamerater samlet til minnestund (overskrift Aftenposten 03.01.2016)

Dødsfallet inntraff nyttårsaften på en hytte $i$ Valdres. Moren er siktet for grov omsorgssvikt med døden til følge (ingress Aftenposten 03.01.2016)

Aftenpostens overskrift og ingress gir dog en noe annen innramming enn VGs, ved at den formidler at en jente på 13 år er død, og at barnets mor er siktet, samtidig som den fremhever nærmiljøets deltakelse i sørgehøytideligheten. Gjennom journalistens og deskens mer selvstendige grep går overskriften på denne måten ut over det politifaglige perspektivet og trekker inn det sosiale. Ingressen er derimot rent politifaglig orientert, og gir opplysninger om tid og sted samt hva siktelsen går ut på.

Ingen av de tre bildene ${ }^{9}$ i Aftenposten har politimotiv. Det første viser blomster og lys i en kirke, det andre et snødekt tettsted med kirken i bakgrunnen, og det siste viser morens advokat. Til sammen utgjør tekst og bilde en kriminalfortelling rammet inn av en situasjonskontekst, der kulturelle og sosiale elementer er fremtredende.

\section{Tragedien som innramming}

I den fjerde saken har VG dekket et drap på en to år gammel jente, og førsteoppslaget er typisk basert på politiets rolle som hovedkilde. Oppslaget, som kommer samme dag som hendelsen finner sted, fremstår som en nyhets- og kriminalsak av tradisjonell refererende karakter. Jeg velger derfor å bevege meg direkte til Aftenpostens oppslag, som kommer samme dag, men som skiller seg fra VGs ved måten fortellingen rammes inn på.

Flere voksne knivskadet - to år gammel jente drept (overskrift Aftenposten 23.05.2014)

Nabo Kåre Snellingen er rystet etter knivdramaet på Ellingsrud $i$ går (ingress Aftenposten 23.05.2014)

9 https://www.aftenposten.no/norge/i/mL8v/Mor-er-siktet-etter-at-datteren-13-dode-pa-hytte-iValdres---Tidligere-skolekamerater-samlet-til-minnestund 
I overskriften omtales dette som en drapssak, og barnets alder, kjønn og bosted blir nevnt. Slik følger også Aftenposten et tradisjonelt mønster for slike saker. Det som er annerledes i tilnærmingen, kommer til syne gjennom ingressens omtale av nærmiljøets reaksjon på knivdramaet. Naboen fremstår med fullt navn, og det første bildet ${ }^{10}$ viser en godt voksen mann som kneler på plenen foran tente lys, nær en boligblokk. Her skapes det et inntrykk av at dødsfallet oppleves personlig for den som er navngitt, og sammen med bildet går assosiasjonene i retning av at barnets død er en rystende hendelse som berører livet til dem som bor i nærområdet. Slik har naboen, som representant for nærmiljøet, blitt plassert i protagonistens posisjon og gitt en stemme - med tragedien som ramme.

Antagonisten i denne fortellingen er svært diskret til stede. Ingen foreldre nevnes i overskrift eller ingress, heller ingen institusjoner som kan stilles overfor et samfunnsansvar. Imidlertid finnes ytterligere et bilde ${ }^{11}$, som er noe mindre enn det første og dessuten plassert langt nede i saken. Det viser tre menn i hvite kjeledresser som inspiserer bakken. I bakgrunnen ses en politimann i full uniform samt flere politisperrebånd som markerer området det letes i. Her slår politilogikken inn ved at bildet konnoterer etterforskningsaktiviteter som ser ut til å handle om å sikre bevis. Slik blir kriminalfortellingens antagonist likevel representert gjennom kun ett enkelt bilde.

\section{Samfunnets tap}

Den femte saken bringer først og fremst noe nytt inn i analysen gjennom Aftenpostens billedbruk i førsteoppslaget. Overskrift og ingress gjør rede for drapet på mor og sønn på tradisjonelt vis. Ingressen plasserer guttens stefar i antagonistens rolle.

Mor og sønn drept i Kirkenes - guttens stefar er siktet (overskrift Aftenposten 29.08.2016)

10 https://www.aftenposten.no/norge/i/ng26L/Flerevoksne-knivskadet---to-ar-gammel-jente-drept

11 https://www.aftenposten.no/norge/i/ng26L/Flerevoksne-knivskadet---to-ar-gammel-jente-drept 
Guttens stefar er hardt skadet etter en skyteepisode i Kirkenes natt til mandag. En kvinne (37) ble funnet drept på stedet, mens hennes 12 år gamle sønn senere døde på sykehus (ingress Aftenposten 29.08.2016)

Tre bilder følger saken ${ }^{12}$. Det første viser Kirkenes barneskole, der flagget vaier på halv stang, det andre viser et kart over det nordligste Norge, mens det tredje viser ordføreren i Sør-Varanger, som er avbildet foran rådhuset. Gjennom billedbruken er det først og fremst de sivile og politisk-administrative institusjonene som får oppmerksomhet, og i denne konteksten konnoterer disse den samfunnsmessige sammenhengen som gutten, hans mor og stefaren sto i. Kartet tolker jeg ikke bare som en enkel stedsangivelse for hendelsen. Det inngår i et samspill med tekst og bilder for øvrig, som samlet sett fremstiller hendelsen som et tap for fellesskapet - for hele det samfunnet som utgjør Sør-Varanger.

\section{Sorg og forsoning}

Som den sjette og siste saken velger jeg å presentere ett av VGs førsteoppslag, siden det er dette som bringer nye momenter inn i analysen. Det publiseres bare timer etter dødsfallet.

Naboer minnes død far (35) og sønn (8): La ned blomster og bamser som siste hilsen (overskrift VG 01.03.2010)

Venner og naboer samlet seg rundt tente lys foran huset $i$ Haugesund der faren (35) og sønnen (8) ble funnet døde mandag (ingress VG 01.03.2010)

Overskriften viser til en markering for både far og sønn, og det er dødsfallene som sosiale hendelser dette handler om - uavhengig av at det kommer frem lenger nede i teksten at politiet arbeider ut fra mistanken om at 35-åringen tok livet av både sønnen og seg selv. Dessuten viser den til nedleggelse av blomster og bamser, og bidrar til å ramme inn saken som en tragisk hendelse av mellommenneskelig karakter. Ingressen følger opp overskriften, og tematiserer en sosial mobilisering blant venner 
og naboer etter at dødsfallene ble kjent. Slik posisjoneres fellesskapet som protagonist i denne teksten.

Antagonisten på sin side er nærmest fraværende, men ikke helt. Det første bildet ${ }^{13}$ viser voksne og barn i veikanten. De står tett samlet, tenner lys og legger ned blomster i nærheten av huset der de omkomne bodde. Slik konnoterer bildet de omkomnes tilhørighet til sitt nærmiljø. Politiets sperrebånd er lite synlige, men de er der. Assosiasjonene går i retning av at dette oppslaget handler om en alvorlig kriminalsak, og vi får en fornemmelse av at det nok finnes en antagonist - men at dette ikke er det viktigste akkurat nå. Her er det sorgen og samværet som gis rom. På det neste bildet ${ }^{14}$ ser vi skolen der den omkomne gutten gikk, og flagget som vaier på halv stang. Dette bildet gir assosiasjoner til at livet på skolen, der gutten gikk sammen med andre barn, er over for denne åtteåringen. Bildene berører oss i sin enkelhet, og det samlede budskapet har en forsonende karakter.

\section{Barnedrapenes stereotype medielogikk}

Materialet som er presentert ovenfor, viser at det eksisterer et visst mulighetsrom for nyansering og perspektivering i media når disse omtaler saker om barn som dør som følge av vold og omsorgssvikt i hjemmet. Men det tydeligste mønsteret som går igjen i de to avisene som er undersøkt, er at politiet velges som hovedkilde. Gjennom en slik praksis formes diskursen i tråd med tradisjonelle kriminalfortellingers logikk og et politifaglig språk: Politiet fremstår som sentral og ansvarlig aktør, og som garantist for borgernes trygghet - der målet er å avsløre og straffe den individuelle forbryteren.

Som vi har sett, forekommer det variasjoner i dette mønsteret. Gjennom noen journalisters mer selvstendige grep utvides diskursen, noe som åpner opp for en mer nyansert fortelling som etablerer andre roller. Samfunnsinstitusjoners tjenesteforsømmelse og skyld blir tematisert, enten alene eller som medansvarlige sammen med barnets foreldre. Systemsvikt innenfor

13 https://www.vg.no/nyheter/innenriks/la-ned-blomster-og-bamser-som-siste-hilsen/a/582187/

14 https://www.vg.no/nyheter/innenriks/la-ned-blomster-og-bamser-som-siste-hilsen/a/582187/ 
hjelpeapparatet blir dermed etablert som et element i diskursen. I tillegg åpner et større kildemangfold for at hendelser der barn som dør som følge av vold og omsorgssvikt i hjemmet, ikke utelukkende blir forstått som kriminalsaker, men også som sosiale hendelser der tragedie, sorg, fellesskap og forsoning fremstår som sentrale dimensjoner. Slik formes diskursen fra tid til annen i tråd med et sivilt og mellommenneskelig rasjonale, og bidrar til forestillinger om menneskets utilstrekkelighet og tilværelsens kompleksitet.

Svært få av de personene som kunne bidratt til ytterligere perspektivering «nedenfra», får imidlertid komme til orde. Kun i ett av førsteoppslagene i det totale materialet finner vi at en av foreldrene blir gitt en stemme: «Tiltalt for å ha ristet babyen sin til døde: Jeg var en god far» (Overskrift i VG 05.12.2016). Her posisjoneres faren både som protagonist og antagonist - i en og samme overskrift - noe som på en tankevekkende måte illustrerer hvordan feltet preges av det komplekse og motsetningsfylte.

Som en konklusjon på de innledende spørsmålene i dette kapittelet er det rimelig å hevde at avisenes valg av kilder må forstås som det helt sentrale utgangspunktet når disse dekker hendelser om vold og omsorgssvikt som fører til barns død. Gjennom dette legges grunnlaget for hvilket språk, hvilke rasjonaler og dermed hvilke virkelighetsbilder som får forrang. Det repeterende og gjenkjennelige mønsteret - med politiet som hovedkilde, i protagonistens rolle, og med individets og privatsfærens potensielt ensidige skyld - går igjen. Et slikt konvensjonelt og smalt hovedmønster kan betegnes som barnedrapenes stereotype førsteoppslagslogikk.

Hva så med de sakene som ikke blir tematisert $\mathrm{i}$ avisene direkte $\mathrm{i}$ forlengelse av hendelsene, men som slås opp først når de kommer til behandling i rettsapparatet? Her byttes gjerne politiet ut med rettsvesenet, som får posisjon som hovedkilde - og bidrar til å ramme inn sakene, gjennom både overskrift og ingress. I den grad førsteoppslagene illustreres med bilder, er det hovedsakelig statsadvokater, politiadvokater, aktor og forsvarere som dominerer. Noen av disse er avbildet i sort kappe. Slik understrekes rettsapparatets eierskap, legitimitet og autoritet. Når rettsvesenet tildeles rollen som hovedkilde, er det også denne institusjonen som posisjoneres som protagonist, og det er rettssystemets språk og rasjonale som legges til grunn i nyhetssaken. Førsteoppslagene kretser dermed rundt 
tiltalen, klargjøring av hendelsesforløpet, vitneføring - og eventuell dom. Slik resirkuleres barnedrapenes stereotype førsteoppslagslogikk, denne gangen med rettsapparatet i hovedrollen.

\section{Andre valg - nye innsikter}

Avisenes praksis - slik den viser seg i denne studien, der politi og rettsvesen i overveiende grad velges som hovedkilde i førsteoppslag om barnedrap, kan i ett perspektiv forstås i lys av medias egne krav til varsomhet, sannhet og objektivitet. Det å støtte seg til politi og rettsvesen fremstår for så vidt som et forsvarlig valg, blant annet fordi disse institusjonene har lang erfaring i å balansere etiske og lovregulerte hensyn overfor media. I kraft av sitt etterforskningsansvar har politiet dessuten en rekke ressurser til rådighet som rettes inn mot å skaffe oversikt over hendelsesforløpet når barn dør plutselig og uventet, og kan derfor bidra med det som oppleves som objektiv, legitim og korrekt informasjon fra en pålitelig kilde, innenfor en presset tidsramme. I et slikt perspektiv kan det fungere som både trygt og ansvarlig å plukke stoff fra en pressekonferanse eller redigere en foreliggende pressemelding. I tillegg er det enklere og dermed ressursbesparende, fordi det ikke krever journalistens selvstendige innsikt hverken i enkeltsaker eller i feltet som helhet. Slik kan nyhetssaker også komme til å følge lønnsomhetskriterier (Allern, 2001). Utfordringen er imidlertid, som vi har sett ovenfor, at disse kildene bygger på perspektiver som har politi- og rettsfaglige verdier og interesser for øye. Dermed risikerer media å fungere som disse statsinstitusjonenes mer eller mindre ureflekterte talerør i den innledende fasen av nyhetssaken, mens andre perspektiver, verdier og interesser blir oversett - eller satt på vent.

Som vi har sett gjennom analysene, finnes det allerede alternative innganger når nyhetssaker om barnedrap presenteres, og det er ikke urimelig å anta at flere kan utvikles (Allern, 2018). Det er med andre ord ingen selvfølge at etablerte autoritetssystemer som politi og rettsapparat må tilkjennes posisjonen som hovedkilde, og at hendelsene må fremstilles først og fremst som kriminalsaker - bortsett fra at dette over år har utviklet seg som den foretrukne måten å skape virkeligheten på. En slik utvikling er imidlertid ikke overraskende sett i lys av at kriminalstoff 
over tid har fått en særlig fremtredende plass og behandling i pressen, og at den voldelige kriminaliteten har fått «en mye mer fremtredende plass og behandling enn den registrerte kriminaliteten skulle tilsi» (Mathisen, 2010 s. 144). Slik kan førsteoppslag om barn som dør som følge av vold og omsorgssvikt i hjemmet, over tid ha utviklet seg til å bli en del av medias stadig stigende voldsfokus.

I et makt- og diskursperspektiv vil et slikt kulturelt betinget valg, der i første rekke autoritetene kommer til orde, bidra til at journalistens faglige rolle innskrenkes, mens politiets og rettsapparatets makt og innflytelse legitimeres og befestes gjennom en diskurs som formes ovenfra. Politiet og rettsapparatet vil, både i egne og i publikums øyne, kunne forstås som de egentlige meningsberettigede - de som forvalter og formidler sannheten. En slik praksis vil innebære en svekkelse av pressens kritiske potensial og dermed også deres funksjon som den «fjerde statsmakt». I lys av pressens samfunnsrolle, nedfelt i Vær Varsom-plakatens pkt. 1.2, har pressen et spesielt ansvar for at ulike syn kommer til uttrykk (note 3). Samme sted understrekes også pressens plikt til samfunnskritikk og til å sette et kritisk søkelys på hvordan mediene selv fyller sin samfunnsrolle (ibid. pkt. 1.4). Pressens eget regelverk understreker med andre ord at det i første rekke er opp til pressen selv å ta dette ansvaret og disse forpliktelsene inn over seg.

Til slutt er det et poeng også å peke på hva som er fraværende i den diskursen jeg har analysert, og dermed hvilke perspektiver som forsvinner fra horisonten. Ingen av førsteoppslagenes overskrifter, ingresser eller bilder reflekterer eller viser til fag- eller forskningsbasert kunnskap om individuelle og strukturelle forhold som kan settes i sammenheng med barnedrap, til tross for at vi har sett at slik kunnskap finnes (ref. s. 211-212). Hverken psykiske problemer, livsbetingelser, sosioøkonomiske kår, utdanning eller deltakelse i arbeidslivet tematiseres. Her kunne både barnevernet, helsevesenet, forskningsmiljøer og andre aktører gitt andre innfallsvinkler til disse hendelsene i en innledende fase.

Denne studien retter utelukkende blikket mot førsteoppslag om barn som dør etter vold og omsorgssvikt i hjemmet, og den har begrenset seg til en analyse basert på overskrifter, ingresser og bilder. På dette grunnlaget har vi sett at nyhetsoppslagene har karakter av å forstå disse hendelsene 
som isolerte og individuelle fenomen som spiller seg ut som kriminelle handlinger i privatsfæren. Kun i liten grad gir de rom for flere syn på hendelsene, eller setter dem inn i et større samfunnsmessig perspektiv som kan bidra til at publikum fra starten av eksponeres for en bredere forståelse av samspillet mellom individuelle, sosiale og strukturelle forhold. Avisers førsteoppslag følges imidlertid gjerne av flere oppslag. Et interessant spørsmål for videre undersøkelser vil være i hvilken grad denne oppfølgingen retter blikket mot en slik bredere forståelse, hvem som eventuelt slipper til som kilder, og dermed hvordan barnedrapenes medielogikk reguleres over tid.

\section{Referanser}

Allern, Sigurd (2001). Kildene og mediemakten. I Martin Eide (Red.), Til dagsorden! Journalistikk, makt og demokrati. Oslo: Gyldendal Norsk Forlag.

Allern, Sigurd (2018). Journalistikk og kildekritisk analyse. Oslo: Cappelen Damm Akademisk.

Barthes, Roland (1999). Mytologier. Oslo: Gyldendal.

Backe-Hansen, Elisabeth, Smette, Ingrid, \& Vislie, Camilla (2017).

Kunnskapsoppsummering. Vold mot barn og systemsvikt. NOVA Rapport 4/2017,

Høgskolen i Oslo og Akershus.

Bang, Tor (2003). Medier og kommunikasjon - en innføring. Oslo: Abstrakt forlag.

Cavanagh, Kate, Dobash, Russel Emerson, \& Dobash, Rebecca P. (2005). Men who murder children inside and outside the family. British Journal of Social Work, 35(5), 667-688. https://doi.org/10.1093/bjsw/bch2O2

Dietz, Park Elliot (1986). Mass, serial and sensational homicides. Bulletin of the New York Academy of Medicine, 62, 477-91.

Eide, Martin (2001). Journalistisk makt. Et oppslag. I Martin Eide (Red.), Til dagsorden! Journalistikk, makt og demokrati. Oslo: Gyldendal Norsk Forlag.

Fiske, John (1996). Media Matters: Everyday Culture and Political Change. Minneapolis: University of Minnesota Press.

Foucault, Michel (1972). The Archaeology of Knowledge. London: Tavistock.

Frandsen, Finn (1991). Avisens paratekst - et nyt område i medieforskningen.

Mediekultur, 16, 79-97. https://doi.org/10.7146/mediekultur.v7i16.947

Gangdal, Jon (2011). Jeg tenker nok du skjønner det sjøl. Historien om Christoffer.

Oslo: Kagge forlag.

Gergen, Kenneth J. (2015). An Invitation to Social Construction. London: Sage.

Gripsrud, Jostein (2015). Mediekultur, mediesamfunn. Oslo: Universitetsforlaget. 
Grünfeld, Berthold, \& Steen, Jens (1984). Fatal barnemishandling: Barnedrap i Norge. Tidsskrift for Norsk Legeforening 104: 289-92.

Haslebo, Gitte, \& Haslebo, Magnus Harald (2010). I Guds eget hus - journalistik som sandhedsvidne. I Gitte Haslebo \& Magnus Harald Haslebo (Red.), Nye veje for journalistik - Når sprog skaber virkeligheder. Danmark: Dansk Psykologisk Forlag.

Hove, Thomas, Paek, Hye-Jin, Isaacson, Thomas, \& Cole, Richard T. (2013). Newspaper Portrayals of Child Abuse: Frequency of Coverage and Frames of the Issue. Mass Communication and Society, 16: 89-108. https://doi.org/10.1080/15205 436.2011.632105

Hågvar, Yngve Benestad (2007). Å forstå avisa. Innføring i praktisk presseanalyse. Bergen: Fagbokforlaget.

Mathisen, Thomas (2010). Makt og medier. En innføring i mediesosiologi. Norway: Pax Forlag.

Meyer, Cheryl L., \& Oberman, Michelle (2001). Mothers Who Kill Their Children. Understanding the Acts of Moms from Susan Smith to the «Prom Mom». New York: New York University Press.

Neumann, Iver B. (2001). Mening, materialitet, makt: En innføring i diskursanalyse. Bergen: Fagbokforlaget.

Ottesen, Vibeke (2016). An Evolutionary Psychological Analysis of Filicide in Norway. Avhandling (dr.polit.). Centre for Ecological Synthesis (CEES). Universitetet i Oslo.

Polkinghorn, Donald (1983). Methodology for the Human Sciences. Systems of Inquiry. Albany: State University of New York Press.

Sidebotham, Peter, Fraser, James, Covington, Teresa, Freemantle, Jane, Petrou, Stavros, Pulikottil-Jacob, Ruth, Cutler, Tessa, \& Ellis, Catherine (2014). Understanding why children die in high-income countries. The Lancet 384 (99946): 915-927. https://doi.org/10.1016/So140-6736(14)60581-x

Ulvestad, Jorun (2010). Spenninger i den språklige samfunnsveven. En kritisk analyse av politiske tekster om foreldre, oppvekst og barnevern. Avhandling (dr.polit.). Det utdanningsvitenskapelige fakultet, Universitetet i Oslo.

Vettenranta, Soilikki (2005). De unge og katastrofenyheter. Oslo: Abstrakt forlag. Veum, Aslaug (2008). Avisas andlet. Førstesida som tekst og diskurs. Dagbladet 1925-1995. Avhandling (dr.polit). Det humanistiske fakultet, Universitetet i Oslo.

\section{Nettreferanser}

Note 1: Jensen, Merete, \& Knut-Ivar Berglund. (2013). Meldeplikt til barnevernet - mot til å se - trygghet til å handle. PPT presentert på konferanse hos Fylkesmannen i Troms. Hentet fra http://docplayer.me/6955055-Meldeplikt-tilbarnevernet-mot-til-a-se-trygghet-til-a-handle.html (Lastet ned 18.02.2018). 
Note 2: Stav, Jannicke (2016, 4. februar). De som mishandler barn til døde går (som oftest) fri. Aftenposten. Hentet fra https://www.aftenposten.no/meninger/debatt/i/ 1397/De-som-mishandler-barn-til-dode-gar-som-oftest-fri--Jannicke-Stav (Lastet ned 28.02.2018).

Note 3: Vær Varsom-plakaten. Hentet fra http://presse.no/pfu/etiske-regler/ (Lastet ned 21.08.2017).

Note 4: Redaktørplakaten. Hentet fra http://presse.no/pfu/etiske-regler/ (Lastet ned 21.08.2017).

Note 5: VG Nett 03.05.2010. Hentet fra https://www.vg.no/nyheter/innenriks/ barnemishandling/33-barn-drept-og-doedelig-mishandlet-av-sineforeldre/a/10004899/ (Lastet ned 06.06.2017).

Note 6: VG Nett 11.03.2014. Hentet fra https://www.vg.no/nyheter/innenriks/ foreldrepar-siktet-etter-at-treaaring-doede/a/10146136/ (Lastet ned 06.06.2017).

Note 7: VG Nett 27.11.2013. Hentet fra https://www.vg.no/nyheter/innenriks/gutt-1funnet-doed-faren-29-paagrepet/a/10140659/ (Lastet ned 06.06.2017).

Note 8: VG Nett 03.01.2016. Hentet fra https://www.vg.no/nyheter/innenriks/krim/ mor-siktet-etter-at-13-aaring-doede/a/2358936o/ (Lastet ned 06.06.2017).

Note 9: Aftenposten 03.01.2016. Hentet fra https://www.aftenposten.no/norge/i/ mL8v/Mor-er-siktet-etter-at-datteren-13-dode-pa-hytte-i-Valdres---Tidligereskolekamerater-samlet-til-minnestund (Lastet ned 06.06.2017).

Note 10: Aftenposten 23.05.2014. Hentet fra https://www.aftenposten.no/norge/i/ ng26L/Flere-voksne-knivskadet---to-ar-gammel-jente-drept (Lastet ned 06.06.2017).

Note 11: Aftenposten 23.05.2014. Hentet fra https://www.aftenposten.no/norge/i/ ng26L/Flere-voksne-knivskadet---to-ar-gammel-jente-drept (Lastet ned 06.06.2017).

Note 12: Aftenposten 29.08.2016. Hentet fra https://www.aftenposten.no/norge/i/ db4xj/Mor-og-sonn-drept-i-Kirkenes---guttens-stefar-er-siktet (Lastet ned 06.06.2017).

Note 13: VG Nett 01.03.2010. Hentet fra https://www.vg.no/nyheter/innenriks/laned-blomster-og-bamser-som-siste-hilsen/a/582187/ (Lastet ned 06.06.2017).

Note 14: VG Nett. 01.03.2010. Hentet fra https://www.vg.no/nyheter/innenriks/laned-blomster-og-bamser-som-siste-hilsen/a/582187/ (Lastet ned o6.06.2017). 


\section{Om forfatterne}

Bente Aamotsbakken er professor emeritus i tekstvitenskap ved Institutt for språk og litteratur ved Universitetet i Sørøst-Norge. Hun har vært ansatt som professor II i Forskningsrådet i egenskap av formidlingskoordinator og programstyreleder. Hennes forskningsinteresser ligger innenfor områdene eldre og nyere retorikk, diskursteorier og litteraturvitenskap. Hun har publisert en rekke vitenskapelige artikler innenfor nevnte emner, vært redaktør for antologier og utgitt monografiske arbeider.

Norunn Askeland er professor i norsk på Institutt for språk og litteratur ved Universitetet i Søraust-Noreg. Ho har skrive doktoravhandling om metaforar om kommunikasjon i lærebøker i norskfaget, og har publisert arbeid nasjonalt og internasjonalt innan metaforteori, metaforanalyse, diskursanalyse, lærebokanalyse og kreativ akademisk skriving. Ho har òg vore redaktør for antologiar og har utgitt både fagbøker og lærebøker.

Hilde Bondevik er professor ved Avdeling for helsefag ved Det medisinske fakultet ved Universitetet i Oslo. Hun er idéhistoriker, og hennes forskningsområder er medisinsk historie, kjønnsperspektiver på sykdom og helse, sykdomsbeskrivelser i skjønnlitteraturen og grunnlagsspørsmål i medisin- og helsefagene. Bondevik har publisert innenfor disse temaene, både forskningsartikler og bøker.

Aud Johannessen er professor i helsefag ved Institutt for sykepleie- og helsevitenskap ved Universitetet i Sørøst-Norge. Hun er også ansatt som seniorforsker ved Nasjonal kompetansetjeneste for aldring og helse. I hovedsak er hennes forskningsfokus eldre, personer med demens og tjenesteutvikling. Johannessen har også vært redaktør og en av flere forfattere i læreboka Yngre personer med demens (2017) og publisert et betydelig antall forskningsartikler og populærvitenskapelig tekster om demens og overforbruk av alkohol og psykofarmaka hos eldre. 
Iben Brinch Jørgensen er førsteamanuensis i retorikk og tekstvitenskap på Institutt for språk og litteratur ved Universitetet i Sørøst-Norge. Hun har forsket på retorikk i stedsutvikling basert på en casestudie av et industriområdes transformasjon fra industrikultur til kulturindustri. Gjennom studiet har hun undersøkt hvordan stedet brukes retorisk og hvilken innflytelse det har på retorisk diskurs og praksis.

Ellen Kristvik er seniorforskar ved Avdeling for helsetjenesteforskning (HØKH) på Akershus universitetssykehus. Ho er antropolog, og har i ei årrekkje arbeidd med kulturelle perspektiv på helse og sjukdom. Behandling og omsorg ved livets slutt, og praksis knytta til død og sorg har vore viktige forskingsfokus for arbeidet hennar. Kristvik har publisert både forskingsartiklar og bøker innanfor desse temaa.

Eva Maagerø er professor i norsk på Institutt for språk og litteratur ved Universitetet i Sørøst-Norge. Hennes forskningsinteresser er systemisk funksjonell lingvistikk, multimodalitet, literacy og resepsjonsstudier. Hun har publisert nasjonalt og internasjonalt innenfor disse områdene.

Olav Solberg er professor emeritus i nordisk litteratur ved Universitetet i Søraust-Noreg. Han har tidlegare vore tilsett i NRK, ved Bergen lærarskole, ved Høgskolen i Telemark og ved Universitetet i Oslo. Solberg har gjeve ut mange bøker og artiklar om litterære og kulturelle emne, bl.a. doktorgradsavhandling om skjemteballadar. Han har lenge vore pådrivar for ei norsk vitskapleg balladeutgåve og har dei siste åra hatt ei prosjektstilling ved Nasjonalbiblioteket knytt til balladeprosjektet, som nyleg er fullført (2016).

Oddgeir Synnes er leiar for Senter for diakoni og profesjonell praksis og førsteamanuensis ved VID vitenskapelige høgskole i Oslo og førsteamanuensis II ved Høgskolen i Molde. Han er filolog og har i ei årrekkje arbeidd med narrative perspektiv innan eldreomsorg og palliativ omsorg. Doktorgraden hans (2012) var ein analyse av palliative pasientar sine forteljingar som narrative identitetskonstruksjonar. 
Lisbeth Thoresen er førsteamanuensis ved Avdeling for helsefag, Institutt for helse og samfunn, Det medisinske fakultet ved Universitetet i Oslo. Thoresen er sykepleier og har en doktorgrad i profesjonsetikk. Hennes forskningsinteresse er teori og praksis nær døden, profesjonsetikk, medisinsk etikk, medikalisering, fenomenologi og fenomenologisk etikk. Thoresen har publisert nasjonalt og internasjonalt innenfor disse temaene.

Jorun Ulvestad er førsteamanuensis i utdanningsvitenskap ved Universitetet i Sørøst-Norge. Hun har forsket på politiske tekster om oppvekst og barnevern, med vekt på språk, makt og styring. I en årrekke var hun prorektor for forskning, utvikling og innovasjon, og ledet institusjonens arbeid med kvinners karriereutvikling til toppstillinger i akademia - og har også publisert forskning på dette feltet.

Geir Winje er dosent og arbeider med religionsfaglige emner i lærerutdanningene ved Universitetet i Sørøst-Norge. Han har tidligere publisert bøker og artikler om religion og kunst, religion og modernitet, og religion i tilknytning til barnehage og skole.

Arnfinn Åslund er førsteamanuensis i norsk litteratur ved Universitetet i Sørøst-Norge med doktoravhandling om Bjørnstjerne Bjørnson, og har ellers publisert bøker og artikler om filosofiske og litterære emner. Stikkord for seneste arbeider: ytringsfrihet, terrorisme, det sublime, estetisk autonomi, blues. 
